\title{
From the Eastern Paratethys to the Pontocaspian basins
}

\author{
late Miocene-Middle Pleistocene magneto- \\ biostratigraphy, sedimentary architecture and faunal \\ turnovers of the shrinking basins of West Eurasia
}

Sergei Lazarev

Utrecht Studies in Earth Sciences

No. 220 
Members of the dissertation committee:

Prof.dr. Anneleen Foubert

Department of Geosciences, University of Fribourg, Switzerland

Prof.dr. Rachel Flecker

School of Geographical Sciences, University of Bristol, Bristol, United Kingdom

Prof.dr. Klaudia Kuiper

Department of Earth Sciences, Vrije Universiteit Amsterdam, Amsterdam, The Netherlands

Prof.dr. Nuretdin Kaymakci

Department of Geological Engineering, Middle East Technical University, Ankara, Turkey

Prof.dr. Josep M. Parés

Centro National de Investigación sobre la Evolución Humana, Burgos, Spain

This research was part of the PRIDE (Pontocaspian RIse and DEmise) project, which received funding from the European Union's Horizon 2020 research and innovation programme under the Marie Skłodowska-Curie grant agreement No. 642973.

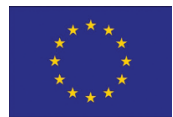

ISBN/EAN: 978-90-6266-583-9

\section{Copyright @ 2020 Sergei Lazarev}

All rights reserved. No part of this publication may be reproduced in any form, by print or photo print, microfilm or any other means, without written permission by the publisher.

Printed by: Ipskamp, the Netherlands. Cover by: Sergei Lazarev and Margot Stoete.

Author contact: sergei_lazarev@outlook.com

Front cover: Landscape in the Denizli Basin (SW Turkey) with outcroups of the Kolankaya Formation on the background.

Back cover: Image of the Caspian Sea from NASA's Visible Earth image catalogue showing the state of the basin in 2005. Image credit: Jeff Schmaltz, NASA. 


\title{
From the Eastern Paratethys to the Pontocaspian basins
}

\author{
late Miocene-Middle Pleistocene magneto- \\ biostratigraphy, sedimentary architecture and faunal \\ turnovers of the shrinking basins of West Eurasia
}

\section{Van de oostelijke Paratethys tot de Pontokaspische bekkens}

laat Miocene-Midden Pleistocene magneto-biostratigrafie, sedimentaire architectuur en faunale omslagen van de krimpende bekkens van West-Eurazië

(met een samenvatting in het Nederlands)

\section{От Восточного Паратетиса к Понто-Каспийским бассейнам}

Позднемиоцен-среднеплейстоценовые магнито-биостратиграфия, осадочная архитектура и биотические изменения в сокращающихся бассейнах западной

Евразии

(с аннотацией на русском языке)

Proefschrift

ter verkrijging van de graad van doctor aan de Universiteit Utrecht op gezag van de rector magnificus, prof.dr. H.R.B.M. Kummeling, ingevolge het besluit van het college voor promoties in het openbaar te verdedigen op vrijdag 10 juli 2020 des ochtends te 10.30 uur

door

Sergei Lazarev

geboren op dinsdag 30 juni 1992

te Tomsk, Russland 
Promotor: $\quad$ Prof.dr. W. Krijgsman

Copromotoren: Dr. C. G. C. van Baak

Dr. H. A. Abels 
Ничто так не освобождает человека, как знание

Иван Тургенев Nothing liberates a human so much as knowledge Ivan Turgenev 


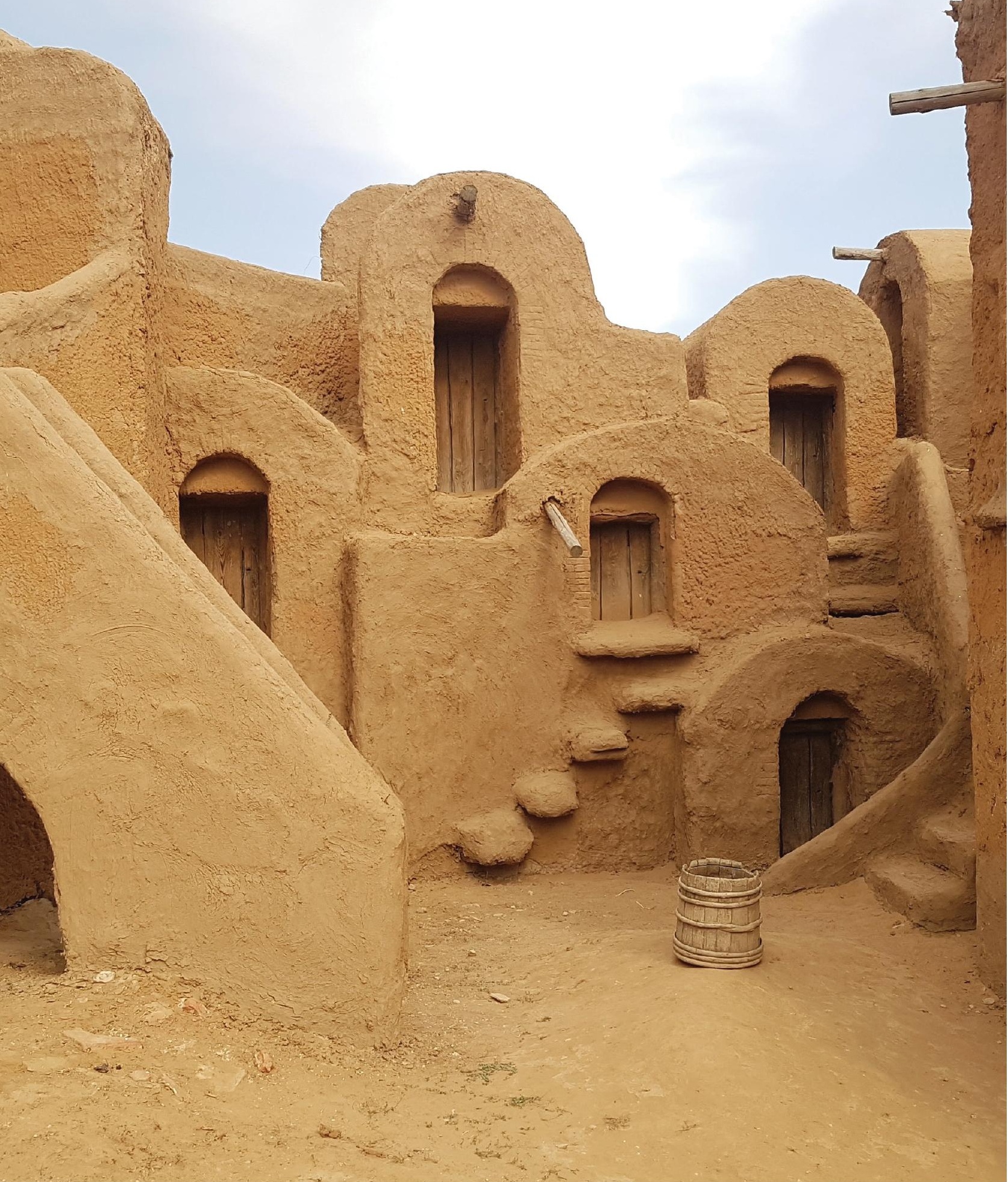

A decorative city Saray-Batu near the Volga River in Astrakhan region, Russia, was built as a decoration for the film "The Horde" and later turned into a museum about the Mongol-Tatars. 


\section{CONTENTS}

I Prologue 9

II Introduction 13

III Summary 19

IV Proloog en samenvatting (in Dutch) 25

V Аннотация (in Russian) 33

Part 1 - Ending of the main endorheic phase in the Eastern Paratethys 37 AND FIRST FAUnAL IMMigrants (LATE Miocene)

1 From Khersonian drying to Pontian "flooding": late Miocene stratigraphy and palaeoenvironmental evolution of the Dacian Basin (Eastern Paratethys)

Part 2 - The hidden Paratethyan affinity: age constraints, depositional environments and faunal record of the Neogene Denizli Basin (SW, Anatolia, Mio-Pliocene)

2 Constraining biogeographic evolution at continental crossroads: age and 85 environmental evolution of the Late Neogene Denizli Basin succession (Turkey)

3 Depositional architecture and drivers of sublacustrine channel-fans in the extensional Denizli Basin (early Zanclen, SW Turkey)

Part 3 - Magneto-biostratigraphy, palaeoenvironments and faunal turnovers in the Kura Basin during the latest Pliocene-Middle Pleistocene

4 Magneto-biostratigraphic age constraints on the palaeoenvironmental evolution of the South Caspian basin during the Early-Middle Pleistocene (Kura Basin, Azerbaijan)

5 The Plio-Pleistocene Akchagylian Flooding in the westernmost Kura Basin (South Caspian region): new and revised magnetostratigraphic age constraints

6 Epilogue

7 Acknowledgements

8 About the author

9 Peer reviewed publications 227

10 References 


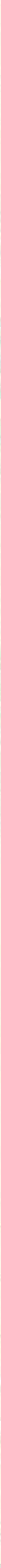

Image of a dust storm over the Aral Sea in 2005. Nowadays, the right branch of the sea is completely gone. Image credit: Jeff Schmaltz, NASA's Visible Earth catalogue. 


\section{Prologue}

The rise of anthropogenic emissions of $\mathrm{CO}_{2}$ in the atmosphere and associated with it increase of the mean annual temperatures disrupts the atmospheric and oceanic circulations (Vellinga and Wood, 2002; Vecchi and Soden, 2007). Consequences of such a process are deterioration of habitat, weather extremes, decrease in biodiversity and ecological restructurings, which are already echoing in every part of the Earth (Global warming of $1.5^{\circ} \mathrm{C}$, 2018).

One of the most pronounced responses of global warming can be seen in endorheic basins. The endorheic basins, characterised by lack of outflow, have a delicate water budget controlled by the interplay between the water supply (riverine, groundwaters and atmospheric precipitation) and the evaporation potential. Between 2002 and 2016, the observations on endorheic basins showed an about $30 \%$ loss of their water volume worldwide (Wang et al., 2018). The brightest and at the same time, the regrettable example is the Aral Sea - the former fourth biggest lake in the world, which now exists as a network of tiny pounds (Pavelsky, 2018). Anthropogenic restriction of the riverine inflow and the overall high evaporation of the basin led to its near-disappearance and collapse of its ecosystems. The negative effect of such an ecological disaster hit the surrounding areas of the Aral Sea, dramatically deteriorating the habitat of the local human population.

The largest endorheic basin in the world is the Caspian Sea located at the crossroad of Europe and Asia. During the Quaternary (2.6 Ma - recent), the global climatic oscillations resulting in glacial-interglacial periods also strongly affected the water budget of the Caspian Sea, leading to its shrinking and expansion. The rise of the Caspian Sea level often resulted in the establishment of short connections with the Black Sea through the Manych Strait. Such reconnection episodes were followed by an exchange of fauna that eventually formed the unified Pontocaspian ecosystem (Krijgsman et al., 2019; Lazarev et al., 2019). One of the most characteristic elements of Pontocaspian ecosystem is endemic mollusc fauna (Wesselingh et al., 2019). In the past decades, amplification of the anthropogenic activity in the Caspian Sea and its catchment areas facilitated in a rapid decrease of endemic mollusc biodiversity. The most severe impact on the basin was the introduction of several invasive species that took over the ecological niches of Pontocaspian molluscs (Lattuada et al., 2020).

In 2015, the European Union's PRIDE project (Pontocaspian ecosystem RIse and DEmise) was dedicated to evaluation of the evolution of the ecosystem and the current biodiversity crisis 
in the Pontocaspian basins. The project combined 15 Early Stage Researchers in geo-, bio- and climate sciences and a network of 21 research institutions across Europe. It aimed to raise awareness on the uniqueness of the Pontocaspian ecosystems as well as to understand both present and past environmental drivers of their rise and demise.

This thesis is one of the 15 ESR projects with an initial goal of creating the age model for the Pontocaspian basins for the past 3 My using an integration of magneto-, bio and cyclostratigraphic techniques. The thesis results also cover the older time interval that deals with the rise of Pontocaspian related species in the Eastern Paratethys. Hence, the emphasis is put on the dating and palaeoenvironmental evolution of the Eastern Paratethyan and Pontocaspian basins in the past $\sim 8 \mathrm{Ma}$. The age constraints are the backbone of all geological and palaeoenvironmental studies as they bring studied processes in clear chronological frames. The thesis focuses on the geological background and dating of three critical episodes of the evolution of the Paratethyan/Pontocaspian mollusc fauna: 1. The first occurrence of Paratethyan/Pontocaspian endemic lineages in the Dacian Basin (Eastern Paratethys) at 6.1 Ma;

2. Dispersal of mollusc fauna from the Eastern Paratethys in the Anatolian lake system between 6.0 and 5.2 Ma; 3. Biological turnovers and establishment of Pontocaspian ecosystems in the Caspian Basin during the latest Pliocene-Quaternary ( 2.7-0.4 Ma). 


\section{Prologue}





\section{INTRODUCTION}

\section{Paratethys}

The Paratethys was an ancient, vast Eurasian sea that once extended from the Alps on the West to western China on the East (Laskarev, 1924; Rögl, 1999; Schulz et al., 2005). Nowadays, small remnants of this sea in the form of the Black and Caspian seas are left. The large-scale evolution of the Paratethys, from its birth until now, was actively controlled by the tectonic collision of the African, Eurasian and Arabian plates, including further several microplates. Around the Oligocene-Eocene transition ( $35 \mathrm{Ma})$, ongoing plate collision separated the Paratethys from the Mediterranean Sea (Schulz et al., 2005). Subsequent evolution of the Paratethys was driven by a prograding collision that resulted in the formation of the Caucasus, Alps, Carpathians and several other mountain ranges. Initially, the Paratethys comprised a Western, Central and Eastern domain. The short-lived and small Western Paratethys formed in the Alpine foreland basin and became isolated at the end of the early Miocene (Senes, 1961; Kuhlemann and Kempf, 2002; Sant et al., 2017). The Central Paratethys remained connected with the global ocean and the Eastern Paratethys until the late Miocene (11.6-11.3 Ma) (Piller et al., 2007; Vasiliev et al., 2010; ter Borgh et al., 2013; ter Borgh et al., 2014). Uplift of the Carpathian mountains disrupted the connection to the Eastern Paratethys and transformed the Central Paratethys into the continental Lake Pannon that eventually disappeared around MioPliocene transition ( 5.3 Ma) (Magyar et al., 1999). The Eastern Paratethys also became isolated since that time and only experienced some occasional short reconnections to the global ocean.

\section{Interbasinal connectivity driving biological turnovers}

Gateway dynamics played a crucial role in the hydrology of Paratethys through time (Popov et al., 2006; De Leeuw et al., 2010; Palcu et al., 2017; Palcu et al., 2019a; Simon et al., 2019). The episodes of interbasinal connectivity and isolation triggered marked changes in salinity, water chemistry and water circulation and served as drivers of faunal migration, radiation and extinction (Magyar et al., 1999; Karami et al., 2011; Palcu et al., 2015; Palcu et al., 2017).

Connectivity periods enabled water exchange between the global ocean and the semiisolated basin, generally characterised by a two-way stratified flow (Fig. 1) (Meijer, 2012). Dense saline water from the global ocean flows on the bottom of the strait into the restricted basin (inflow). In contrast, lighter fresh/brackish water from restricted basin flows into the global ocean on the surface (outflow). Changing the inflow-outflow dimensions may have a severe 


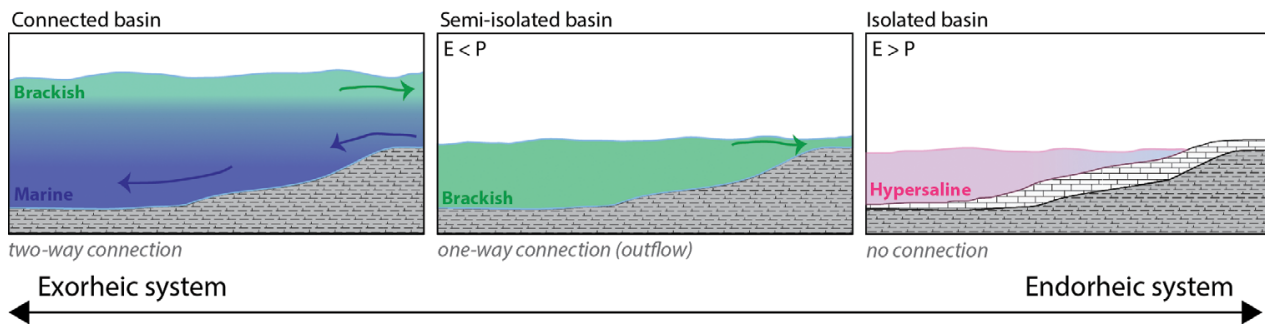

Figure 1 Types of interbasinal connectivity (modified after Bohacs et al., 2003).

impact on the salinity of the basin, provoking biological turnover. A key example is the Black Sea after the Last Glacial Maximum (LGM) that transformed from an isolated freshwater lake into the semi-isolated brackish water basin that it is today, with a modern connection to the Mediterranean (Myers et al., 2003).

Isolation periods are mostly caused by a complex interplay of climatic and tectonic processes that both influence the sill in the gateway area (Leever, 2007; ter Borgh et al., 2014). Being cut from the global ocean, the water budget of restricted basins becomes highly dependent on a delicate balance between local precipitation $(\mathrm{P})$ and evaporation (E) (Simon et al., 2019). Disconnection may lead to the establishment of positive $(P>E)$, negative $(P<E)$ and rarely balanced $(\mathrm{P}=\mathrm{E})$ water budgets in the isolated basin, with a different effect on their base level (Fig. 1).

A positive water budget will raise the base level until it reaches the height of the sill and begins to overspill. Consequently, the salinity will decrease due to the increasing amount of water. Characteristic examples of periods with positive water budget in the Eastern Paratethys are the middle Miocene (Karaganian) and the early Messinian (Maeotian). At that time, a climatically-driven increase of precipitation provoked transgressions that flooded the central and satellite basins of the Eastern Paratethys facilitating the migration of brackish water faunal communities (Popov et al., 2006; Palcu et al., 2019b).

A negative water budget will lead to a drop in the base level and may even result in basin desiccation. Subsequent raise of salinity in the isolated basins may be lethal for basin ecosystems. A well-known example of such a system is the Messinian Salinity Crisis (MSC) in the Mediterranean (Roveri et al., 2014a; Flecker et al., 2015). Restriction of the AtlanticMediterranean connection together with global climate aridification resulted in the neardesiccation of the Mediterranean and the formation of km-thick evaporitic salt (Herbert et al., 2016; Capella et al., 2018).

The episodes of connection and isolation in restricted basins are thus always reflected in changes in salinity and water chemistry provoking massive biological turnovers. During the late Miocene-Early Pleistocene amplification of Northern Hemisphere climatic oscillations made the Paratethyan water budget even more sensitive, which resulted in base-level fluctuations of 
several hundred meters of amplitude causing enormous expansions and dramatic regressions (Popov et al., 2006; Krijgsman et al., 2019). This is also clearly shown by the biotic record that reveals numerous biological turnover events. The major events in Paratethys include:

- Isolation of the Eastern Paratethys, and following depletion of marine ecosystems that culminated in massive extinction during the Khersonian drying between 12.65 and 7.65 Ma (Iljina et al., 1976; Kojumdgieva et al., 1989; Lazarev et al., 2019 (submitted); Palcu et al., 2019b).

- Pontian "flooding" of the Eastern Paratethys characterised by the occurrence of marine groups and brackish water communities from the Central Paratethys (Lake Pannon) at 6.1 Ma (Rybkina et al., 2015; van Baak et al., 2016; Lazarev et al., 2019 (submitted)).

- Lago Mare phase of the Messinian Salinity Crisis, which marks the expansion of Paratethyan ecosystems into the Mediterranean between 5.37 and 5.33 Ma (Taviani et al., 2007; Stoica et al., 2016; Grothe et al., 2018);

- Isolation of the Caspian Sea from the Black Sea Basin, leading to the disappearance of Paratethyan communities around $~ 5.38 \mathrm{Ma}$; (van Baak et al., 2016)

- Akchagylian flooding of the Caspian Basin, with occurrence, depletion and extinction of Akchagylian mollusc fauna between 2.7 and 2.1 Ma; (Lazarev et al., 2019; van Baak et al., 2019)

- Apsheronian connection between the Black and Caspian Seas, creating the Pontocaspian ecosystems in the Caspian Basin from 2.1 Ma until nowadays (Krijgsman et al., 2019; Lazarev et al., 2019).

All these events and their causes and consequences eventually shaped the modern Pontocaspian ecosystems of the Black and Caspian seas (Taktakishvili, 1977; Magyar et al., 1999; Wesselingh et al., 2019). Many drivers of the biological turnovers in Paratethys seem resolved; however, many questions regarding the biogeography, species ecology and link with climatic and tectonic background remain unclear.

\section{Stratigraphic problems and pitfalls in semi-isolated systems}

The dependence of semi-isolated basins on gateway dynamics makes them environmentally unstable through time. Unlike regular marine basins, the Eastern Paratethys alternately acted as a fully marine, semi-isolated or isolated basin with salinity ranges from polyhaline to freshwater. Transitions accompanied by biological turnovers made biotic records highly significant for the regional subdivision and correlation. The key-group used in regional Paratethys stratigraphy is the mollusc fauna (Borissjak, 1937; Vereshchagin, 1982; Nevesskaya et al., 2004).

The Eastern Paratethys is a highly complex water body that comprised several smaller scale basins like the Caspian Sea, Black Sea (Euxinian) and Dacian Basin (Fig. 2). These basins differed in water depth, water circulation, gateway activity, catchment area and tectonic settings and thus may react to the regional changes with a delay or a less pronounced response. These 


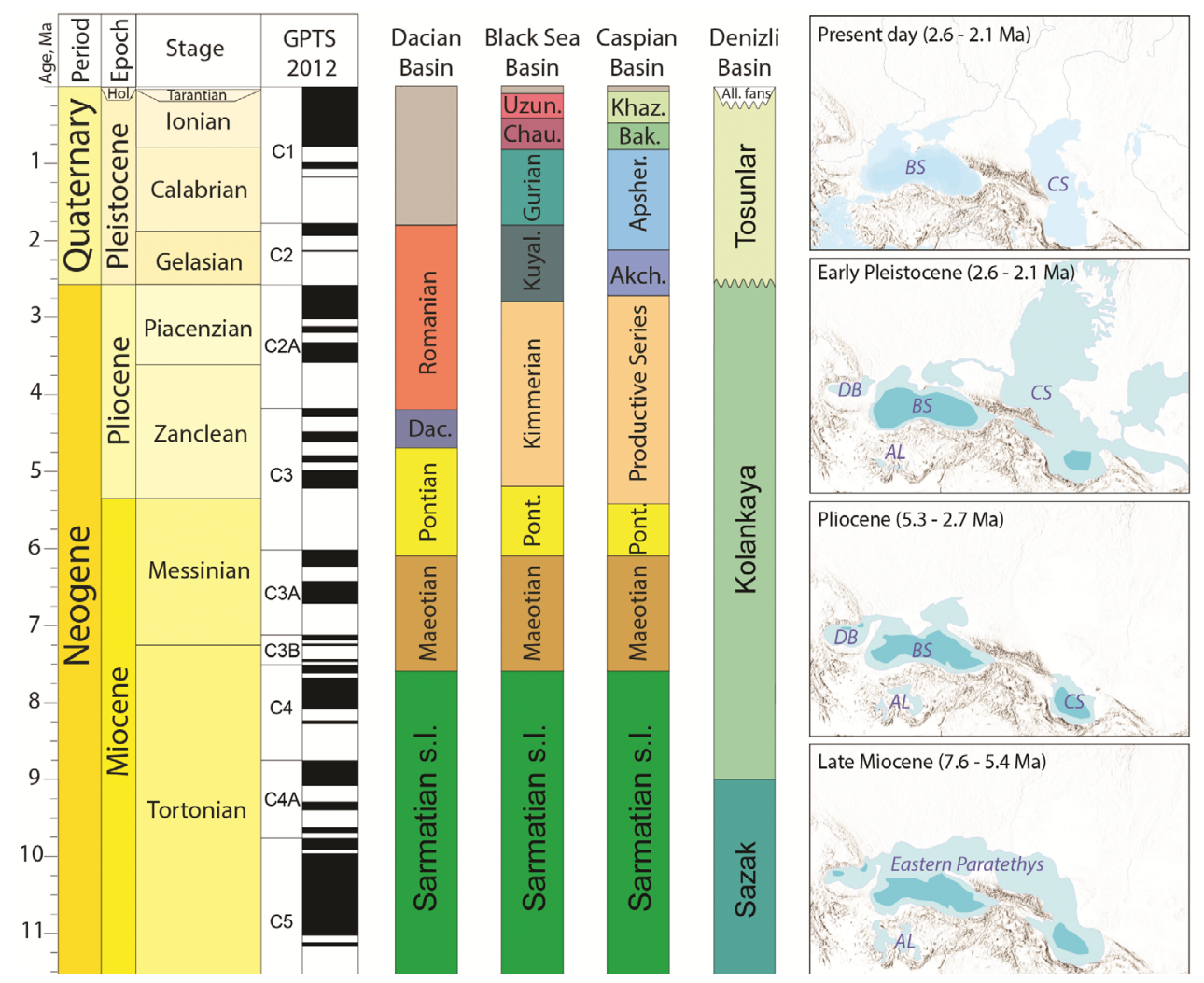

Figure 2 Global Time Scale (GTS), regional stages of Paratethyan (Dacian, Black Sea and Caspian) basins and continental Denizli Basin, and palaeogeographic sketches of the Eastern Paratethys. On the sketches: BS - Black Sea, CS - Caspian Sea, DB - Dacian Basin, AL - Anatolian Lakes. References: GTS 2012 (Hilgen et al., 2012), Dacian Basin stratigraphy (Jipa and Olariu, 2009; Krijgsman et al., 2010; van Baak et al., 2015b; Lazarev et al., 2019 (submitted); Palcu et al., 2019b), Black Sea and Caspian Sea stratigraphies (Krijgsman et al., 2019), Denizli Basin stratigraphy (Alçiçek et al., 2007a; Doğan et al., 2020), contours of the basin are redrawn after (Lüttig and Steffens, 1975; Popov, 2004).

circumstances often lead to controversies on the regional stratigraphic schemes, resulting in different definitions for stages and their boundaries.

One of the key examples is the late Miocene Pontian Stage (Fig. 2). The lower boundary is synchronous for the entire Eastern Paratethys and dated at 6.1 Ma, but the upper boundary varies from basin to basin. In the Caspian Sea, this boundary is with the Productive Series and is placed at 5.38 Ma when the basin became isolated from the rest of the Eastern Paratethys, and the Paratethyan brackish water fauna was replaced by freshwater groups (van Baak et al., 2016). In the Black Sea, the upper limit of the Pontian is with the Kimmerian, placed at $5.2 \mathrm{Ma}$ (Nevesskaya et al., 2004; Gladenkov, 2018) or alternatively at 5.5 Ma (Vasiliev et al., 2011). In 
the Dacian Basin, the upper Pontian boundary is with the Dacian regional stage and dated at 4.7 Ma (Jipa and Olariu, 2009; Krijgsman et al., 2010).

The mollusc-based biostratigraphy, however, does not always fully explain the palaeoenvironmental context of newly occurring faunas, neither their internal relationships. Moreover, it is still unknown how other faunistic groups behave at these boundaries. Significant improvements of old geological proxies and involvement of new techniques show a high complex palaeoenvironmental changes that cannot be (and should not be) explained by using only one proxy. Solving the issue of the stratigraphic problem of the upper Pontian boundary requires a multi-lateral integrated approach to better understand basin evolution and faunal biogeography.

The philosophy of this thesis lies in the multi-disciplinary approach to obtain better knowledge of palaeoenvironmental reconstructions and their chronology. The thesis shows that it is essential for specialists from various disciplines to work together, to integrate dating techniques (magnetostratigraphy, ${ }^{40} \mathrm{Ar} /{ }^{39} \mathrm{Ar}$-dating), geochemical $\left({ }^{87} \mathrm{Sr} /{ }^{86} \mathrm{Sr}\right.$ isotopic ratio), and to combine palaeontological (ostracod, foraminifera, molluscs, dinoflagellates) and sedimentological (facies analysis) proxies. 


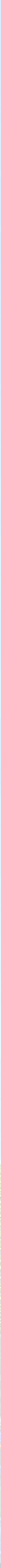

The St. George monument on the Freedom Square in Tbilisi, Georgia. September 2018. 


\section{SUMMARY}

The first part of the thesis investigates the palaeoenvironmental and depositional evolution of the Dacian Basin during the late Miocene, which we placed in a magnetostratigraphic time frame. The Dacian Basin is a Carpathian foreland basin and forms the westernmost branch of the Eastern Paratethys. In the late Miocene, a complex of climatic and regional tectonic reorganizations caused the isolation of the Eastern Paratethys from the global ocean (De Leeuw et al., 2010; Leever et al., 2010; Popov et al., 2010; Palcu et al., 2015; De Leeuw et al., 2018; Palcu et al., 2019b; Simon et al., 2019). The following disruption of the water budget resulted in strong water level fluctuations accompanied by changes in salinity and implicitly fauna and ecosystems (Karami et al., 2011; Vasiliev et al., 2015; Simon et al., 2019). The most substantial base level drop occurred in the Khersonian regional stage and was responsible for whipping out the last marine faunal groups in the basin (Iljina et al., 1976; Paramonova, 1994). The succeeding climatically-driven Maeotian transgression refilled the basin and facilitated the spreading of brackish water faunas across the Eastern Paratethys (Popov et al., 2006; Palcu et al., 2019b). At the end of Maeotian, a short influx of marine microfauna known as "Pontian "flooding" characterizes the establishment of a short connection with the global ocean (Krijgsman et al., 2010; van Baak et al., 2016). At the same time, a short, enigmatic connection between the Central (Lake Pannon) and Eastern Paratethys allowed the invasion of numerous Pannonian faunal groups (mollusc, dinoflagellates and ostracods) into the Eastern Paratethys (Magyar et al., 1999). Consequently, these groups gave rise to new faunal lineages that nowadays constitute the modern ecosystems of western Eurasia. The Dacian Basin having an intermediate position between the Central and Eastern Paratethys was the first refuge of the migrating Pannonian species. Despite a well-studied taxonomy, several uncertainties exist regarding the age and palaeoenvironmental context of this migration event.

In Chapter 1 "From Khersonian drying to Pontian "flooding": late Miocene stratigraphy and palaeoenvironmental evolution of the Dacian Basin (Eastern Paratethys)", we present our study of a $1.4 \mathrm{~km}$-thick section along the Slănicul de Buzău River (Romania) that covers a fairly complete Khersonian- Maeotian-lowermost Pontian succession. We used a combination of magnetostratigraphic dating, high-resolution analysis of sedimentary facies, and analysis of ostracod and mollusc fauna to document and to date the palaeoenvironmental changes and reaction of the faunal and depositional records of the Dacian Basin to fluctuations of the Eastern Paratethys hydrology in the late Miocene. 
Our data shows that in the late Khersonian (7.7-7.63 Ma) a predominantly freshwater coastal plain with occasional brackish water incursions existed in the study area. This general lowstand was terminated by a low mesohaline early Maeotian transgression at $\sim 7.63 \mathrm{Ma}$, followed by the installation of littoral/nearshore environments with freshwater molluscs in shallow settings and oligohaline ostracods in slightly deeper settings. Subsequent delta progradation and prevalence of freshwater fauna in both marginal and more distal environments characterize the late Maeotian. It was followed by a remarkable freshwater transgression that started at $6.3 \mathrm{Ma}$ and led to establishment of offshore depositional environments. The late Maeotian fossil record indicates brackish water pulses from Lake Pannon (Central Paratethys), followed by mass occurrences of Coelogonia novorossica. At 6.1 Ma, a short influx of meso- to polyhaline microfauna including benthic and planktonic foraminifera defines the "Pontian Salinity Incursion". Molluscs, including Eupatorina littoralis, that biostratigraphically mark the onset of the Pontian arrived with a negligible delay of $\sim 5 \mathrm{kyr}$ after the microfauna influx. The onset of the Pontian at Slănicul de Buzău at $6.1 \mathrm{Ma}(\sim \pm 5 \mathrm{kyr})$, is synchronous with the salinity incursion observed in other Paratethyan basins. Our integrated approach, placing the preserved fossil fauna in its respective sedimentary environment, allows for a detailed insight into the salinity of coeval marginal as well as basinal environments and can now be more widely applied to the Paratethys realm and other semi-isolated basins with deviating salinities.

The second part of the thesis focuses on dating and palaeoenvironmental reconstruction of the Denizli Basin - a small intracontinental basin located in SW Anatolia (Turkey). The late Miocene depositional record of the basin contains the characteristic Pontocaspian mollusc genus Didacna, closely related to those in the modern Caspian Sea (Wesselingh et al., 2008). However, besides the taxonomic study, neither integrated palaeoenvironmental background nor absolute dating have been established before.

In Chapter 2 "Late Miocene palaeoecological turnover in the Denizli Basin", we applied magnetostratigraphic dating, analysis of mollusc and ostracod associations as well as a few test measurements of nannofossils, dinoflagellates and ${ }^{87} \mathrm{Sr} /{ }^{86} \mathrm{Sr}$ in the $1.4 \mathrm{~km}$-thick Babadag section. The goal of this study is to determine the timing and palaeoenvironmental background for the first occurrence and rise of Pontocaspian Biota in this Anatolian palaeolake. Our study reveals two distinct lake phases characterised by distinctive mollusc and microfauna assemblages. The lower Phase 1 ( 6.0-5.6 Ma) contains endemic mollusc fauna of a Paratethyan affinity with genera Dreissena, Melanopsis, Theodoxus, Valvata, Ecrobia, Pyrgula etc. and ostracod fauna dominated by genus Amnicythere. The aquatic palynology shows freshwater algae Botryococcus, brackish water/marine dinoflagellates Achomosphaera, Galeacysta and Spiniferites suggest the proximity of freshwater marginal settings and a potential periodic connection with a higher salinity basin. The upper Phase $2(\sim 5.6-5.1 \mathrm{Ma})$ contains Pontocaspian type mollusc assemblages with Didacna, Theodoxus, Micromelania sp. and ostracod assemblages dominated 
by Leptocythere, Cyprideis, Candona, Amnicythere genera etc. The aquatic palynology mostly comprises Botryococcus dominated assemblages. These two phases are separated by a lithological shallowing trend interpreted as lake level drop. This drop marks a biological turnover dated at 5.6 Ma. We propose that this event reflects the consequences of the Messinian Salinity Crisis in the Mediterranean basin that suffered from increased aridification. The following introduction of the Pontocaspian/Paratethyan Didacna assemblage correlates to the Lago Mare event - the time when the Eastern Paratethys started spilling into the desiccated Mediterranean bringing water and numerous faunal groups. Faunistic and geochemical proxies show that the Anatolian Lake system was a part of the Paratethyan realm during late Mioceneearly Pliocene and its biogeographic role is yet to be studied.

Chapter 3 entitled "Depositional architecture and drivers of sublacustrine channel-fans in the extensional Denizli Basin" is dedicated to the high-resolution facies analysis and analyses of ostracod and mollusc fauna of the Denizli Basin. This chapter aims at the reconstruction of depositional architecture during the rise of the Pontocaspian assemblages in the basin. Our study shows that the early Zanclean depositional record of the Denizli Basin was characterised by a massive progradation of sublacustrine channel-fans into deeper parts of the basin. The sublacustrine channel-fans had a complex depositional architecture and included such architectural elements as feeding channels, distal fans, sublacustrine channel-levees and proximal fans with distributary channels. The ostracod and mollusc faunas indicate that in the early Zanclean the basin had oligohaline to low mesohaline ( 5-10 psu) water salinity with Didacna mollusc group occupying the offshore parts of the basin. In contrast, the low-brackish to freshwater fauna with Micromelania and Theodoxus genera inhabited the marginal parts of the lake. The abrupt progradation of the channel-fans in the early Zanclean is likely to be related to the uplift of the Menderes Massif and activation along the basin-bounding Babadag fault zone. We also speculate that the rise of the regional palaeo-precipitation in the early Zanclean could play an essential role in amplification of debris flows in the basin.

The third part of the thesis focuses on the high-resolution dating and palaeoenvironmental reconstruction of the Kura Basin (South Caspian Basin) during the Early-Middle Pleistocene. During that time, the Caspian Basin was mostly isolated and experienced large lake level fluctuations and short episodes of connection with the open ocean as well as the Black Sea Basin. The consequent changes in water chemistry and interbasinal water exchange triggered several biological turnovers and eventually shaped a faunal record that forms the backbone of the Caspian geological time scale. One of the major turnovers - the Akchagylian-Apsheronian transition - is an extinction of the endemic Akchagylian fauna and its replacement with the Pontocaspian communities. However, the precise ages of these events were still highly debated, due to the lack of the well-studied section and refinement of the Geomagnetic Polarity Time Scale (GPTS) in the last decades. 
In Chapter 4, we provide an integrated magneto-biostratigraphic age model for two sections from the Kura Basin (South Caspian Basin) - Goychay and Hajigabul. Our results show that the extreme Pliocene lowstand of the Caspian Basin (Productive Series) was terminated by the mesohaline Akchagylian transgression around the Gauss-Matuyama reversal ( 2.7-2.6 $\mathrm{Ma}$ ). This transgression was linked to establishment of the connection between the Caspian Basin and the Arctic Ocean. The consequent failure of this connection and freshening of the Caspian basin provoked extinction of Akchagylian endemic fauna. At 2.13 Ma (correlating to the Reunion subchron) we detected the first occurrence of typical Pontocaspian molluscs - Monodacna sp. and Apscheronia propinqua that mark the onset of Apsheronian stage. Their occurrence resulted from the re-established connection between the Caspian and the Black Sea basins. The following Bakunian transgression, characterised by the major spread of Didacna molluscs, was dated at 0.83-0.85 Ma, slightly below the Brunhes-Matuyama polarity reversal. Above it, within the Brunhes normal chron, we also discovered two other flooding events with new mollusc, ostracod and foraminifera fauna, attributed to upper Bakunian and Khazarian.

Our integrated age constraints brought new insights into timing and expression of the major biological turnovers in the Early-Middle Pleistocene of the Caspian Basin. Our study confirmed the $\sim 2.7 \mathrm{Ma}$ age of the onset of the Akchagylian Stage in the central and eastern parts of the Kura Basin, which was recently argued to be $2.7 \mathrm{Ma}$ (van Baak et al., 2019) rather than 3.6 Ma (Trubikhin, 1977). Confusingly, in the westernmost part of the Kura Basin, the Akchagylian deposits in the key-section Kvabebi were dated at 3.2 Ma (Agustí et al., 2009), sharply contradicting our data from other sections across the Kura Basin.

In Chapter 5, we revisit this western part of the Kura Basin and present our results of magnetostratigraphic and radioisotopic $\left({ }^{40} \mathrm{Ar} /{ }^{39} \mathrm{Ar}\right)$ dating of two sections - Kvabebi and Kushkuna. These sections represent nearshore, lagoon and floodplain depositional settings which transition upwards into continental and fluvial environments. Both sections contain remains of Akchagylian brackish water molluscs and large terrestrial mammals. This feature has been previously used to date the regional large mammalian complexes by correlation with the Akchagylian Stage. However, the age controversy on the base of the Akchagylian of nearly 0.5 Ma has a high impact on understanding and reconstruction of the large mammalian evolution and regional distribution. Our magnetostratigraphic data from both sites revealed a long normal chron that switches to reversed in the upper parts of the sections. We correlate the normal polarities with the upper part of the Gauss chron ( 3.0-2.6 Ma). This correlation has been confirmed by the ${ }^{40} \mathrm{Ar} /{ }^{39} \mathrm{Ar}$ dating of the ash layer from Kvabebi that provided an age $2.86 \mathrm{Ma}$. In both sections, the Akchagylian mollusc fauna disappears slightly below the Gauss-Matuyama polarity switch. This suggests termination of mesohaline environments in the westernmost Kura Basin at the onset of northern hemisphere glaciations around 2.6 Ma. 
SUMMARY 


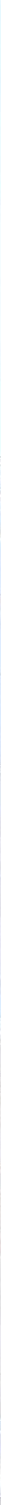

View towards the Blue Mosque from the Hagia Sofia, Istanbul, Turkey. January 2019. 


\section{Proloog en Samenvatting}

De toename van antropogene $\mathrm{CO}_{2}$-uitstoot in de atmosfeer en de daarmee samenhangende verhoging van de gemiddelde jaartemperaturen verstoort de atmosferische en oceanische circulaties (Vellinga en Wood, 2002; Vecchi en Soden, 2007). Consequenties van een dergelijk proces komen tot uiting in de achteruitgang van leefgebieden, extreme weersomstandigheden, afname van biodiversiteit en ecologische herstructureringen. Al in elk deel van de aarde weerklinken deze gevolgen (Global warming of $1.5^{\circ} \mathrm{C}, 2018$ )

Een van de meest uitgesproken gevolgen van de opwarming van de aarde kan worden waargenomen in endorheïsche bekkens. Deze bekkens, gekenmerkt door een gebrek aan afwatering, hebben een delicaat waterbudget dat wordt gecontroleerd door het samenspel van de watervoorziening (rivier, grondwater en atmosferische neerslag) en het verdampingspotentieel. In de periode 2002-2016 toonden de waarnemingen van endorheïsche bekkens een verlies van ongeveer 30\% van de totale watervolume wereldwijd (Wang et al., 2018). Een voorbeeld van deze terugval in water budget is het Aralmeer - dit voormalige op vier na grootste meer ter wereld bestaat nu alleen als een netwerk van kleine meertjes (Pavelsky, 2018). Antropogene beperkingen van de instroom van rivieren en de algehele hoge verdamping van het bekken leidde tot de bijna complete verdwijning en instorting van het ecosysteem. De ecologische ramp heeft de omliggende gebieden van het Aralmeer getroffen, voornamelijk door de leefomgeving van de lokale menselijke bevolking drastisch te verslechteren.

Het grootste endorheïsche bekken ter wereld is de Kaspische Zee, gelegen op het kruispunt van Europa en Azië. Tijdens het Kwartair (afgelopen 2,6 miljoen jaar) hebben de globale klimaatschommelingen, uitgedrukt in glaciale-interglaciale perioden, ook een grote invloed op het waterbudget van de Kaspische Zee gehad. De stijging van de Kaspische Zee spiegel resulteerde vaak in kortstondige verbindingen met de Zwarte Zee via de straat van Manych (Popov, 1970; Svitoch et al., 2010). Dergelijke verbindingsepisodes gingen gepaard met een uitwisseling van de fauna, wat uiteindelijk het verenigde Pontokaspische ecosysteem vormde (Yanina, 2012; Krijgsman et al., 2019; Lazarev et al., 2019). Een karakteristiek element van het Pontokaspisch-ecosysteem is de endemische schelpenfauna (Wesselingh et al., 2019). In de afgelopen decennia heeft de toename van antropogene activiteiten in de Kaspische Zee en het omliggende afwateringsgebied een versnelde teruggang van de endemische weekdierbiodiversiteit veroorzaakt (van de Velde, 2019). De meest ernstige gevolgen op het bekken werden veroorzaakt door de verontreiniging van het bekken en de introductie van 
verschillende invasieve soorten die de ecologische niches van Pontokaspische weekdieren overnamen (Lattuada et al., 2020).

In 2015 werd het PRIDE-project van de Europese Unie (Pontocaspian ecosysteem RIse en DEmise) aangewezen om de evolutie van de Pontokaspische bekkens en de huidige biodiversiteitscrisis te onderzoeken. Het project combineerde 15 Early Stage Researchers (ESR) in geo-, bio- en klimaatwetenschappen en een netwerk van 21 onderzoeksinstellingen in heel Europa. Een van de doelen was om bewustzijn te creëren over het unieke karakter van het Pontokaspische ecosysteem en om zowel de huidige als de vroegere oorzaken van de opkomst en ondergang van de endemische biodiversiteit te begrijpen.

Dit proefschrift is het resultaat van een de 15 ESR-projecten. Het doel was om een geologisch tijdsmodel van de Pontokaspische bekkens van de afgelopen drie miljoen jaar te creëren, met behulp van magneto-, bio- en cyclostratigrafische dateringstechnieken. De resultaten van dit proefschrift hebben ook betrekking op een ouder tijdsinterval dat de opkomst van Pontokaspisch-gerelateerde soorten in de oostelijke Paratethys omvat. Daarom wordt de nadruk gelegd op de datering en evolutie van het paleomilieu van de oostelijke Paratethysche en de Pontokaspische bekkens van de afgelopen $\sim 8$ miljoen jaar. Een goed geologisch tijdmodel vormt de ruggengraat van alle geologische en paleomilieu-studies, aangezien ze de bestudeerde processen in een duidelijke chronologische kaders zetten. Het proefschrift richt zich op de geologische achtergrond en de datering van drie belangrijke episodes binnen de evolutie van de Paratethysch / Pontokaspisch molluskenfauna: 1. De eerste verschijning van Paratethysch / Pontokaspisch endemische soorten in het Dacische Bekken (oostelijke Paratethys) rond 6,1 miljoen jaar geleden; 2. De verspreiding van molluskenfauna uit de oostelijke Paratethys in het Anatolische merenstelsel tussen 6,0-5,2 miljoen jaar geleden; 3. De biologische verandering en vestiging van Pontokaspische ecosystemen in het Kaspische bekken tijdens het Kwartair $(\sim 2,7-$ 0,4 miljoen jaar).

In het eerste deel van dit proefschrift wordt het paleomilieu en de afzettingsgeschiedenis van het Dacische Bekken tijdens het laat Mioceen onderzocht. Dit wordt verder in een magnetostratigrafisch tijdsframe geplaatst. Het Dacische Bekken is een voorland van het Karpatengebergte en vormde tijdens het laat Mioceen het meest westelijke uiteinde van de oostelijke Paratethys. In die tijd leidde het samenspel van paleoklimaat en regionale tektoniek tot de isolatie van de oostelijke Paratethys van de open oceaan (De Leeuw et al., 2010; Leever et al., 2010; Popov et al., 2010; Palcu et al., 2015; De Leeuw et al., 2018; Palcu et al., 2019b; Simon et al., 2019). De daaropvolgende disruptie van het hydrologisch budget resulteerde in sterke fluctuaties in het water niveau, saliniteit, fauna en ecosystemen (Karami et al., 2011; Vasiliev et al., 2015; Simon et al., 2019). De grootste zeespiegeldaling in deze periode gebeurde tijdens de Khersonian regionale tijdsperiode. Deze was verantwoordelijk voor het volledig uitsterven van de laatste mariene fauna in het bekken (Iljina et al., 1976; Paramonova, 1994). De daaropvolgende, door klimaatveranderingen veroorzaakte, Maeotische transgressie vulde 
het bekken weer met water, waardoor een brakwaterfauna zich kon verspreiden door de hele oostelijke Paratethys (Popov et al., 2006; Palcu et al., 2019b). Aan het einde van de Maeotian regionale tijdsperiode wijst de aanwezigheid van een mariene microfauna tijdens de Pontische transgressie op een kortstondige verbinding met de oceaan (Krijgsman et al., 2010; van Baak et al., 2016). Op datzelfde moment zorgde een verbinding tussen de centrale Paratethys (het Pannon Meer) en de oostelijke Paratethys voor de introductie van Pannonische fauna groepen (mollusken, dinoflagellaten en ostracoden) in de oostelijke Paratethys (Magyar et al., 1999). Deze groepen vormen de basis van het huidige ecosysteem van westelijk Eurazië. Dankzij de locatie tussen de centrale en oostelijke Paratethys vormde het Dacische Bekken een eerste refugium voor Pannonische soorten. Er zijn, ondanks een goed bestudeerde taxonomie, meerdere onzekerheden gerelateerd aan de ouderdom en paleomilieu van deze faunamigratie.

In Hoofdstuk 1 "Van Khersonische verdroging naar Pontische overstroming: laat Miocene stratigrafie- en paleomilieu-evolutie van het Dacische Bekken (oostelijke Paratethys)" presenteren we onze studie van een 1.4 kilometer dikke sedimentopeenvolging langs de Slănicul de Buzau rivier in Roemenië. Op deze locatie is een complete opeenvolging van Khersonian, Maeotian, en het onderste Pontian te bestuderen. Dit hebben wij gedaan aan de hand van een combinatie van magnetostratigrafische ouderdomsbepalingen, een analyse van sedimentaire facies in hoge resolutie, en analyse van de ostracoden- en molluskenfauna. Hiermee documenteren we de ouderdom van de veranderingen in paleomilieu, en de reactie van de fauna en het afzettingsmilieu in het Dacische Bekken op fluctuaties van de hydrologie van de oostelijke Paratethys in het laat Mioceen.

Onze data laat zien dat in ons studiegebied in het laatste deel van het Khersonian (7.77.63 miljoen jaar geleden) een overwegend zoetwater kustvlakte bevond met sporadische brakwater incursies. Deze laagstand eindigde door een laag-mesohaliene transgressie tijdens het vroeg Maeotian ( 7.63 miljoen jaar geleden). Als het gevolg van deze transgressie vormde zich een littoraal / kustnabij afzettingsmilieu met zoetwater mollusken in ondiepe milieus, en oligohaliene ostracoden in de iets diepere delen. Een prograderende delta en zoetwaterfauna zowel in de marginale en distale milieus karakteriseren het laat Maeotian. Dit wordt gevolgd door een opmerkelijke zoetwater-transgressie vanaf 6.3 miljoen jaar geleden, wat leidde tot een offshore afzettingsmilieu. Het fossiele record van het laat Maeotian wijst op pulsen van brakwater vanuit het Pannon Meer (centrale Paratethys), gevolgd door massavoorkomens van Coelogonia novorossica. Een kortstondige influx van meso- tot polyhaliene indicatieve microfauna (inclusief bentische en planktonische foraminiferen) 6.1 miljoen jaar geleden kenmerkt de "Pontian Saliniteits-incursie". Mollusken kenmerkend voor het Pontian, waaronder Eupatorina littoralis, verschijnen met een verwaarloosbare vertraging van $\sim 5,000$ jaar na de microfauna influx. Het begin van het Pontian in Slănicul de Buzau is met een ouderdom van 6.1 miljoen jaar ( \pm 5,000 jaar) synchroon aan de saliniteitsincursie zoals waargenomen in andere van de Paratethys. Onze geïntegreerde aanpak waarmee we de fossiele fauna in de 
afzettingsmilieus plaatsen, maakt het mogelijk om in detail saliniteitsveranderingen te beschrijven in tijdsequivalente marginale- en diepe afzettingsmilieus. Deze aanpak kan worden toegepast in de hele Paratethys regio en in semi-geïsoleerde bekkens met afwijkende saliniteit.

Het tweede deel van dit proefschrift richt zich op het dateren en reconstrueren van paleomilieus in het Denizli Bekken; een klein intracontinentaal bekken in zuidwest Anatolië (Turkije). Afzettingen uit het laat Mioceen in dit bekken bevatten het karakteristieke Pontokaspische mollusk genus Didacna, welke sterk gerelateerd is aan mollusken in de huidige Kaspische Zee (Wesselingh et al., 2008). Hoewel de taxonomie van deze soort in het verleden is onderzocht, zijn er veel vragen over de paleomilieus en datering van deze voorkomens.

In Hoofdstuk 2 "Paleo-ecologie omslag in het laat Mioceen van het Denizli Bekken", passen we magnetostratigrafische dateringen toe, een analyse van mollusk- en ostracode-associaties en meerdere testmetingen van nannofosielen, dinoflagellaten en ${ }^{87} \mathrm{Sr} /{ }^{86} \mathrm{Sr}$ in de 1,400 meter dikke Babadağ sectie. Het doel van deze studie is om de timing en achterliggende paleomilieus te bepalen voor de eerste voorkomens van de Pontokaspische biota in dit Anatolische paleomeer. Onze studie laat zien dat er in twee verschillende fases een meer vormde, met kenmerkende mollusk- en microfauna assemblages. De oudere Fase 1 ( 6.0-5.6 miljoen jaar geleden) bevat een endemische molluskfauna met Paratethysche affiniteit met de genera Dreissena, Melanopsis, Theodoxus, Valvata, Ecrobia, Pyrgula etc. en een ostracodefauna gedomineerd door het genus Amnicythere. De aquatische palynologie bevat Botryococcus zoetwateralgen, daarbij ook de brakwater / mariene dinoflagellaten Achomosphaera, Galeacysta en Spiniferites. Dit wijst op de nabijheid van marginale zoetwater omstandigheden en mogelijk een periodieke verbinding met een bekken met hogere saliniteit. De jongere Fase $2(\sim 5.6-5.1 \mathrm{Ma})$ bevat Pontokaspische mollusk-assemblages met Didacna, Theodoxus, Micromelania sp., en ostracode-assemblages met daarin dominante genera Leptocythere, Cyprideis, Candona, Amnicythere etc. De aquatische palynologie bevat vooral assemblages met dominante Botryococcus algen. Deze twee fases worden gescheiden door een lithologische verontdiepings-trend die wij interpreteren als een verlaging van het waterniveau in het meer. Deze verlaging van het waterniveau markeert de biologische omslag en dateren we op 5.6 miljoen jaar geleden. Wij stellen voor dat dit een gevolg is van aridificatie gerelateerd aan de saliniteitscrisis in de Middellandse Zee tijdens het Messinien (MSC). De daarop volgende introductie van Pontokaspische/Paratethysche Didacna assemblages correleert met het Lago Mare - het moment waarop de oostelijke Paratethys overstroomde naar de Middellandse Zee en met het water ook meerdere fauna groepen werden geïntroduceerd. Onze data van fauna en geochemische proxies laat zien dat het Anatolische meersysteem onderdeel was van de Paratethys tijdens het laat Mioceen en vroeg Plioceen, waarbij de biogeografische rol verder bestudeerd moet worden.

Hoofdstuk 3 getiteld "Architectuur en mechanismes van sub-lacustriene stromingswaaiers in het extensionele Denizli Bekken" bevat een facies analyse in hoge resolutie, en analyse van de ostracode- en mollusk fauna van het Denizli Bekken om de diepwaterafzettingen ten tijde van 
de eerste Pontokaspische assemblages in dit bekken te bestuderen. Onze studie laat zien dat afzettingen uit het vroeg Zanclien worden gekenmerkt door grootschalige progradatie van sub-lacustriene stromingswaaiers richting diepere delen van het bekken. De sub-lacustriene stromingswaaiers bevatten een complexe afzettingsarchitectuur waaronder toevoergeulen, distale waaiers, sub-lacustriene stromingswallen en proximale waaiers met distributiegeulen. De ostracode- en mollusk-faunas wijzen op een oligohaliene tot laag mesohaliene saliniteit ( 5-10 psu), waarin de Didacna groep in de diepwaterdelen van het bekken leefde, en laagbrakwater tot zoetwater fauna met de genera Micromelania en Theodoxus in de marginale delen van het meer. De abrupte progradatie van de stromingswaaiers in het vroeg Zanclien is waarschijnlijk het gevolg van het omhoog komen van het Menderes Massief en activatie langs de Babadağ breukzone aan de rand van het bekken. Daarnaast speculeren wij dat de regionale toename van de paleo-precipitatie in het vroeg Zanclien een belangrijke rol kan hebben gespeeld in het vorming van puinwaaiers in het bekken.

Het derde deel van dit proefschrift richt zich op het in hoge resolutie dateren en reconstrueren van paleomilieus van het Kura Bekken (zuid Kaspische Bekken) tijdens het vroeg en midden Pleistoceen. Op dat moment was de Kaspische Zee vooral geïsoleerd, en ondervond grote fluctuaties in water niveau en kortstondige verbindingen met de oceaan en de Zwarte Zee. De gerelateerde veranderingen in waterchemie en de instabiele bekkenverbindingen leidde tot meerdere biologische omslagen. De fossielopeenvolging die hierdoor ontstond, vormt de basis van de Kaspische geologische tijdschaal. Eén van deze grote omslagen, de Akchagylian-Aspheronian transitie, ziet het uitsterven van endemische Akchagyl fauna en de eerste introductie van Pontokaspische fauna in de Kaspische Zee. De exacte ouderdom van deze omslag is niet goed bekend door een gebrek aan goed gedateerde sedimentopeenvolgingen van deze periode.

In Hoofdstuk 4 presenteren we een geïntegreerde magneto-biostratigrafisch ouderdomsmodel voor twee secties in het Kura Bekken (zuid Kaspische Bekken), bekend onder de namen Goychay en Hajigabul. Onze resultaten laten zien dat de extreme Pliocene laagstand van de Kaspische Zee (de zogeheten Productive Series) werd beëindigd door de mesohaliene Akchagyl transgressie rond de Gauss-Matuyama magnetische omkering ( 2.7-2.6 miljoen jaar geleden). Deze transgressie was gerelateerd aan de vorming van een verbinding tussen de Kaspische Zee en de Arctische Oceaan. Het sluiten van deze verbinding, en de daarop volgende verzoeting van de Kaspische Zee leidde tot het uitsterven van de endemische Akchagyl fauna. Rond 2.13 miljoen jaar geleden (gecorreleerd aan het Reunion magnetisch subchron) vinden we de eerste voorkomens van typisch Pontokaspische mollusken, Monodacna sp. en Apscheronia propinqua, en daarmee de basis van de Apsheronian tijdsperiode. Dit werd mogelijk doordat een verbinding werd gevormd tussen de Zwarte Zee en de Kaspische Zee. De daarop volgende Bakunian transgressie wordt gekarakteriseerd door een grote toename in Didacna soorten. Dit wordt gedateerd op 0.83-0.85 miljoen jaar oud, juist onder de Brunhes-Matuyama 
polariteitsomkering. In de jongere lagen van de sectie, als onderdeel van het Brunhes normale chron, zijn twee jongere transgressies beschreven met nieuwe data van mollusken, ostracoden en foraminiferen. Deze transgressie behoren tot het bovenste Bakunian en Khazarian.

Onze geïntegreerde ouderdomsbepalingen scheppen nieuw inzicht in de timing en expressie van grote biologische omslagen in het vroeg- en midden Pleistoceen van de Kaspische Zee. Zo bevestigd onze studie een ouderdom van $\sim 2.7$ miljoen jaar oud voor het begin van de Akchagylian stage in het centrale en oostelijke deel van het Kura Bekken. Deze ouderdom is recent voorgesteld (van Baak et al., 2019), in tegenstelling tot een oudere bepaling van 3.6 miljoen jaar (Trubikhin, 1977). In het meest westelijk deel van het Kura Bekken daarentegen, zijn de Akchagyl-afzettingen in de belangrijke Kvabebi sectie gedateerd op 3.2 miljoen jaar oud (Agustí et al., 2009).

In Hoofdstuk 5 bestuderen wij opnieuw dit westelijk deel van het Kura Bekken en presenteren onze resultaten van magnetostratigrafische en radio-isotopische $\left({ }^{40} \mathrm{Ar} /{ }^{39} \mathrm{Ar}\right)$ dateringen van twee secties, de eerder genoemde Kvabebi sectie en de Kushkuna sectie. Deze secties bevatten kustnabije afzettingen, lagune en overstromingsvlakte afzettingsmilieus, en veranderen in het jongere deel naar continentale en rivierafzettingen. Beide secties bevatten zowel Akchagylian brakwater mollusken en terrestrische grote zoogdierfossielen. De controverse in de ouderdommen zorgt ervoor dat op dit moment geen simpele correlatie tussen continentale en aquatische tijdschalen gemaakt kan worden. Onze nieuwe magnetostratigrafische data geeft in beide locaties een lang normaal chron wat in het bovenste deel van de sectie ompoolt naar reverse. Deze normale polariteit correleren wij naar de Gauss chron ( 3.0-2.6 miljoen jaar geleden). Dit wordt verder ondersteund door een ${ }^{40} \mathrm{Ar} /{ }^{39} \mathrm{Ar}$ datering van een vulkanische aslaag in de Kvabebi sectie met een ouderdom van $\sim 2.86$ miljoen jaar oud. In beide secties verdwijnt de Akchagylian mollusk fauna voor de Gauss-Matuyama ompoling. Dit suggereert dat de mesohaline condities in het meest westelijke deel van het Kura Bekken verdwenen ten tijde van de eerste vorming van ijskappen op het noordelijk halfrond 2.6 miljoen jaar geleden.

Translation by Sabrina Van de Velde and Christiaan van Baak. 
Prologue and summary (DUtCh) 


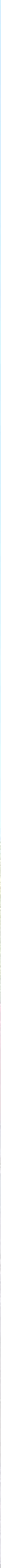

Kalmykia is a national republic in Russia located on the Caspian Sea coast. It is the only Buddist republic in Europe. The Pagoda of Seven Days in the capital of Kalmykia Elista. August 2017. 
Наблюдаемый в последние десятилетия активный рост антропогенных выбросов углекислого газа неуклонно ведет к росту среднегодовых температур и нарушает баланс в атмосферной и океанической циркуляциях (Vecchi and Soden, 2007; Vellinga and Wood, 2002). Последствия этих процессов, выраженные в ухудшении среды обитания, экстремальных погодных условиях, сокращении биоразнообразия и экологических перестройках, уже сегодня отзываются эхом в каждом уголке Земли (Global warming of $\left.1.5^{\circ} \mathrm{C}, 2018\right)$.

Наиболее сильный удар глобальное потепление уже нанесло по бессточным бассейнам. Бессточные бассейны, как не имеющие гидрологического стока, обладают очень чувствительным водным бюджетом, формирующимся за счет поступающих (впадающие реки, грунтовые вод, атмосферные осадки) и испаряющихся вод. Наблюдения, проведенные в период с 2002 по 2016 год показали, что вследствие глобального потепления бессточные бассейны по всему миру потеряли около 30 \% своей водной массы (Wang et al., 2018). Наиболее драматичным примером является Аральское море - некогда четвертый в мире по размеру континентальный водоём, сейчас представляет собой сеть из мелких остаточных озеp (Pavelsky, 2018). Причиной столь быстрого сокращения Арала явилось нарушение водного бюджета в результате агрессивной хозяйственной деятельности, сокращения речного стока, а также усиливающаяся глобальным потеплением испаряемость бассейна. Как результат, практически полное исчезновение Аральских экосистем, разрушенная экономика региона и ухудшение условий обитания местного населения.

Самым крупным бессточным бассейном современности является Каспийское море-озеро, расположенное на пересечении Европы и Азии. В течении Четвертичного периода (2.6 млн лет назад - настоящее время), глобальные климатические колебания, выраженные в серии ледниковых-межледниковых интервалов, также оказывали сильное влияние на водный бюджет Каспийского моря, приводя то к сокращению водоёма, то к его расширению. Расширение Каспийского моря часто сопровождалось его соединением с Черным морем через Кумо-Манычскую впадину (Fedorov, 1957; Svitoch et al., 2010; Yanina, 2012). Краткровременные периоды связи между бассейнами приводили к к прямым миграциям водных организмов, что в итоге сформировало единую эндемичную 
Понто-Каспийскую (Черное и Каспийское моря) экосистему (Krijgsman et al., 2019; Lazarev et al., 2019; Svitoch, 2014; Yanina, 2013). Наиболее характерной частью этой экосистемы является уникальная фауна моллюсков (Wesselingh et al., 2019).

В последние десятилетия, рост хозяйственной деятельности в акватории Каспийского моря привел к вымиранию значительной части эндемичных моллюсков. Наибольший вред был нанесен загрязнением и разведением инвазивных видов, быстро оккупировавших экологические ниши Понто-Каспийских эндемиков (Lattuada et al., 2020). Моделирование климатического влияния на Каспийский регион в перспективе до 2100 года показало, что из-за глобального потепления уровень Каспия может опуститься на 18 метров (Nandini-Weiss et al., 2020), что может очень негативно отразиться на Понто-Каспийских экосистемах.

В 2015 году, проект Европейского Союза PRIDE (Становление и сокращение ПонтоКаспийских экосистем) был призван оценить масштабы кризиса биоразнообразия в Понто-Каспийском регионе, а также провести сравнительный анализ с аналогичными кризисами в геологическом прошлом и ближайшем будущем региона. Проект объединил 15 молодых исследователей в области геологических, биологических и климатических наук, а также 21 научный институт Европы. Главной задачей проекта являлось активное донесение до общественности уникальности Понто-Каспийских эндемичных экосистем, а также изучение современных и прошлых факторов их становления и упадка.

Данная диссертация представляет результаты одного из 15 проектов, основной целью которого было датирование нескольких ключевых геологических разрезов, охватывающих историю Понто-Каспийского региона за последние 8 млн лет. Основные методы, представленные в этой диссертации включают магнитостратиграфию, ${ }^{40} \mathrm{Ar} /{ }^{39} \mathrm{Ar}$-датирование, биостратиграфию (моллюски, фораминиферы, остракоды и динофлагелляты) и седиментологию. Основной фокус в данной работе был сделан на реконструкции геологического контекста и датировании трёх ключевых эпизодов в эволюции Паратетис/Понто-Каспийской фауны моллюсков: 1. Первое появление Паратетис/Понто-Каспийских эндемичных групп в Дакийском бассейне (Восточный Паратетис) в 6.1 млн лет назад; 2. Распространение моллюсков из Восточного Паратетиса в Анатолийские озера между 6.0 и 5.2 млн лет назад; 3. Экологический переворот и становление Понтокаспийских экосистем в Каспийском бассейне в течение позднего Плиоцена - Плейстоцена (2.7-0.4 млн лет назад).

Translation by Sergei Lazarev. 
Prologue (Russian) 

2.5. H.t.

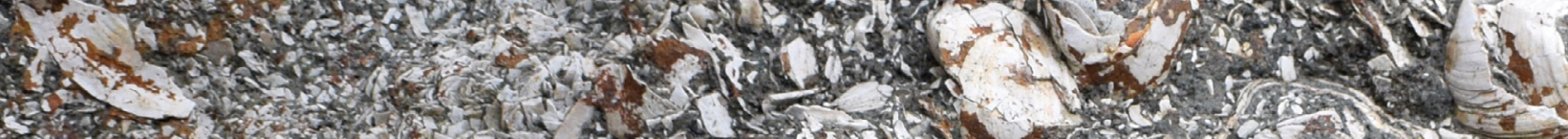

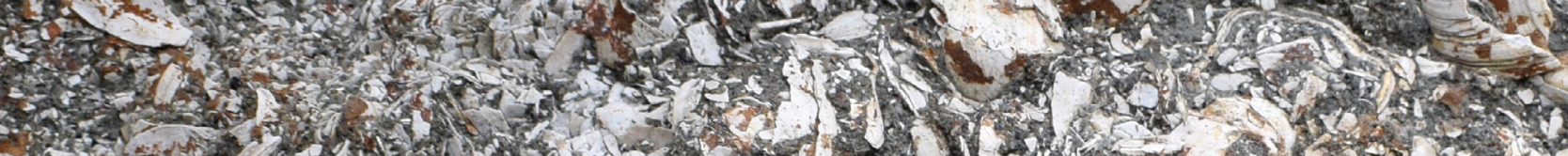

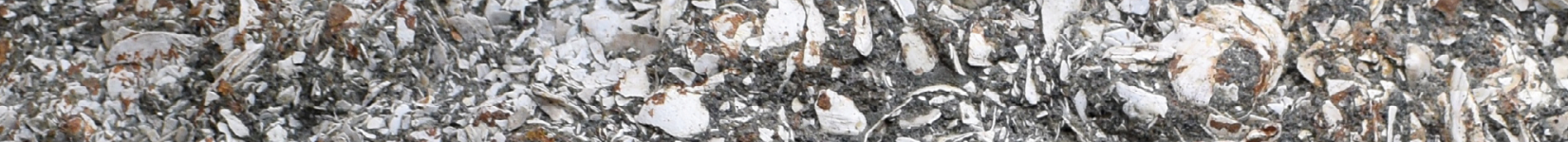
1
1 1.5.

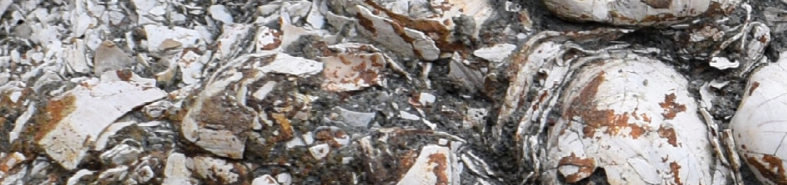

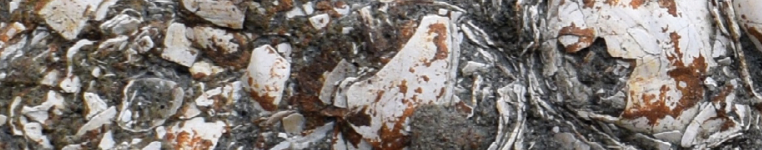

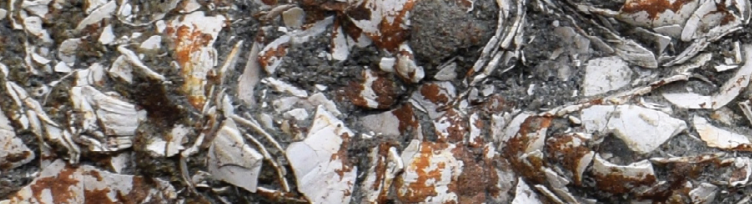

to

(1)
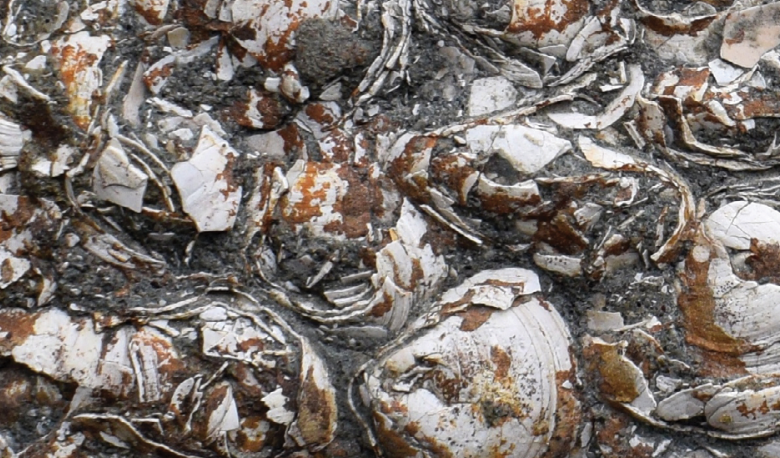

3) (sint

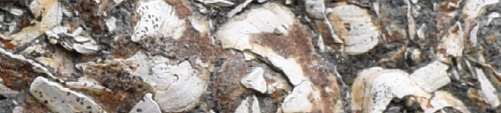

The genus Chersonimactra was one of the last survivors in the Eastern Paratethys during the Great Khersonian drying. The monospecific beds found all the way from the Dacian Basin (Romania) to the Caspian Basin (Kazakhstan) point at a strong ecological crisis in the entire 


\section{Part 1}

ENDING OF THE MAIN ENDORHEIC phase in the Eastern Paratethys AND FIRST FAUNAL IMMIGRANTS (Late Miocene). 


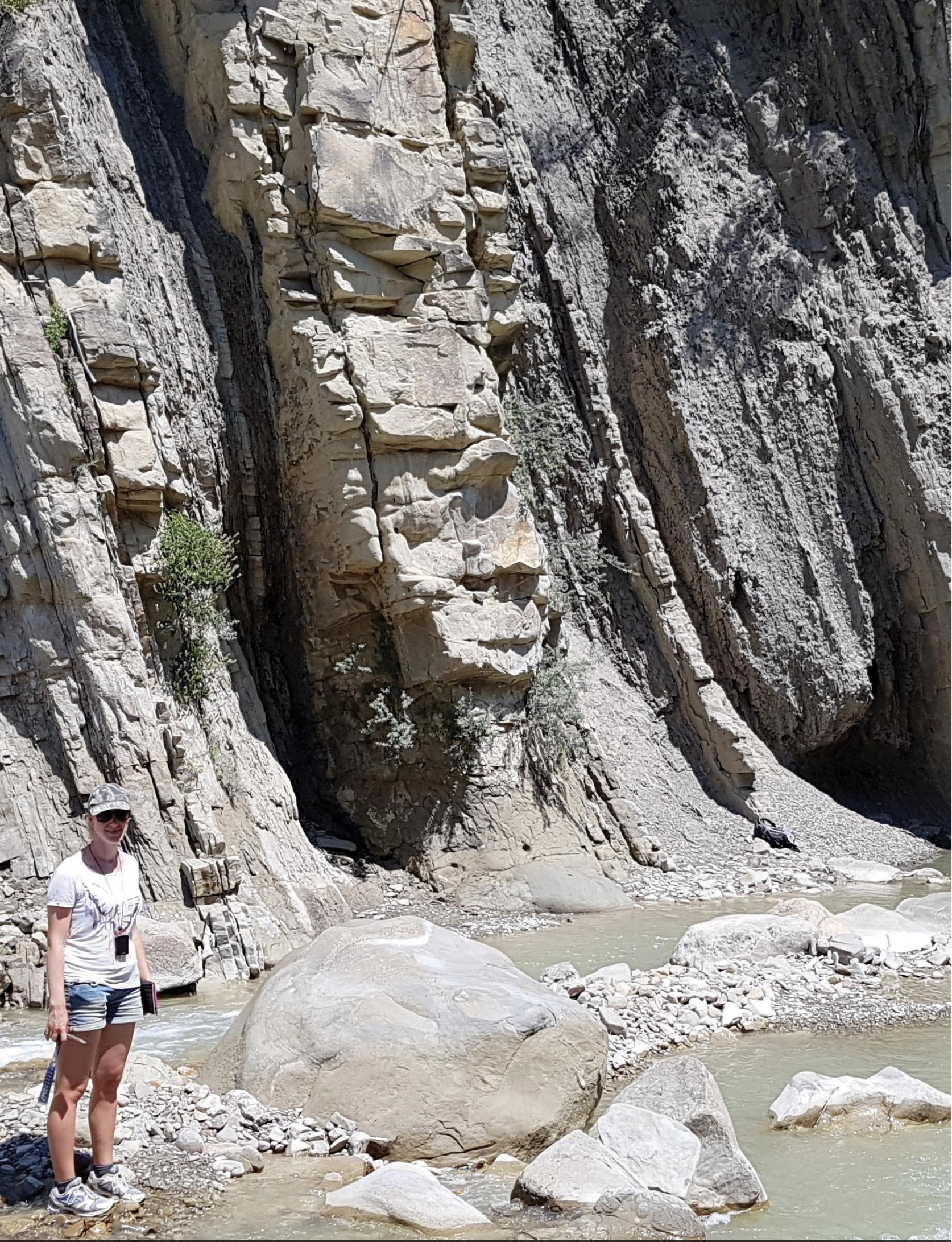

The uppermost Maeotian deposits in the Rîmnicu Sãrat Valley, Dacian Basin (Romania). On 


\section{1}

From Khersonian drying to Pontian "FLOODING": LATE MIOCENE STRATIGRAPHY AND PALAEOENVIRONMENTAL EVOLUTION OF the Dacian Basin (Eastern Paratethys).

Published:

Lazarev, S., Leeuw, A. de, Stoica, M., Mandic, O., van Baak, C.G.C., Vasiliev, I., Krijgsman, W., 2020a. From Khersonian drying to Pontian "flooding": late Miocene stratigraphy and palaeoenvironmental evolution of the Dacian Basin (Eastern Paratethys). Global and Planetary Change 192, 103224. 10.1016/j.gloplacha.2020.103224. 


\section{Abstract}

In the late Miocene, a large inland sea known as the Eastern Paratethys stretched out across the present-day Black Sea - Caspian Sea region. The basin was mostly endorheic and its water budget thus strongly dependent on regional climate. The basin was therefore prone to high-amplitude base-level fluctuations and associated turnovers in water chemistry and fauna. Profound palaeoenvironmental changes happened in the Eastern Paratethys during this time period. This article documents the evolution of the Dacian Basin of Romania, the westernmost branch of the Eastern Paratethys, during the time interval between 7.7 and 6.0 Ma. Our integrated study of sedimentary facies, micro- and macrofauna along the Slănicul de Buzău Section was constrained with a timeframe based on magnetostratigraphy. The remarkable $1.3 \mathrm{~km}$-thick sedimentary record, high depositional rate $(0.65-1.26 \mathrm{~m} / \mathrm{kyr})$ and abundance of fossils along this section provide a unique opportunity to study sedimentary and biotic turnovers in great detail. Our analyses reveal several marked base-level and salinity changes: A predominance of freshwater coastal plain environments, only occasionally flooded, indicates a low base-level in the Khersonian (7.7-7.63 Ma). This lowstand was terminated by a low mesohaline early Maeotian transgression, followed by the installation of littoral/nearshore environments with freshwater molluscs in shallow settings and oligohaline ostracods in slightly deeper settings. Subsequent delta progradation and prevalence of freshwater fauna in both marginal and more distal environments characterize the late Maeotian. This was followed by a remarkable freshwater transgression that started at $6.3 \mathrm{Ma}$ and led to predominantly offshore deposition. The late Maeotian fossil record suggests brackish water pulses from Lake Pannon (Central Paratethys), followed by mass occurrences of Coelogonia novorossica. At $6.1 \mathrm{Ma}$, a short influx of meso- to polyhaline microfauna including benthic and planktonic foraminifera defines the "Pontian Salinity Incursion". Molluscs, including Eupatorina littoralis, that biostratigraphically mark the onset of the Pontian arrived with a negligible delay of $\sim 5 \mathrm{ky}$ after the microfauna influx. The onset of the Pontian at Slănicul de Buzau at $6.1 \mathrm{Ma}(\sim \pm 5 \mathrm{ky})$, is thus synchronous with the onset in other Paratethys basins. Our integrated approach, placing the preserved fossil fauna in its respective sedimentary environment, allows for a detailed insight into the salinity of coeval marginal as well as basinal environments and could be more widely applied in the Paratethys realm and other semi-isolated basins with a deviant salinity.

\subsection{Introduction}

Plate tectonic collision processes generally cause uplift of extensively elongated mountain ranges, which can transform marginal epicontinental seas into semi-isolated basins. These basins may become completely isolated brackish water lakes, sometimes with ephemeral connections to the open ocean, and their palaeoenvironmental evolution and sedimentological architecture are different from normal marine basins (Stoica et al., 2013; Jorissen et al., 2019). The Oligocene-Miocene Paratethys Sea of Central Eurasia, and its present-day remnants the 
Black Sea and Caspian Sea, are archetypes of such semi-isolated basins. During the Miocene, tectonic uplift of the Alpine-Carpathian-Dinaride-Pontides-Caucasus mountains isolated the Paratethys from the Tethys Ocean and separated this ancient sea into several long-lived anomalohaline lake systems in the Pannonian, Dacian, Euxinian and Caspian basins (Popov et al., 2006). In these anomalohaline water masses, the faunal response to tectonically and climatically induced base-level variations, and the related changes in depositional environment, are still poorly understood and require detailed integrated studies.

The Miocene evolution of the Paratethys region (Fig. 1.1A) has become a major research focus over the last decades. In particular, the link between events in the Paratethys and the stepwise evolution of the Messinian Salinity Crisis in the Mediterranean Sea was investigated (Vasiliev et al., 2005; Popescu, 2006; Gillet et al., 2007; Krijgsman et al., 2010; Leever et al.,

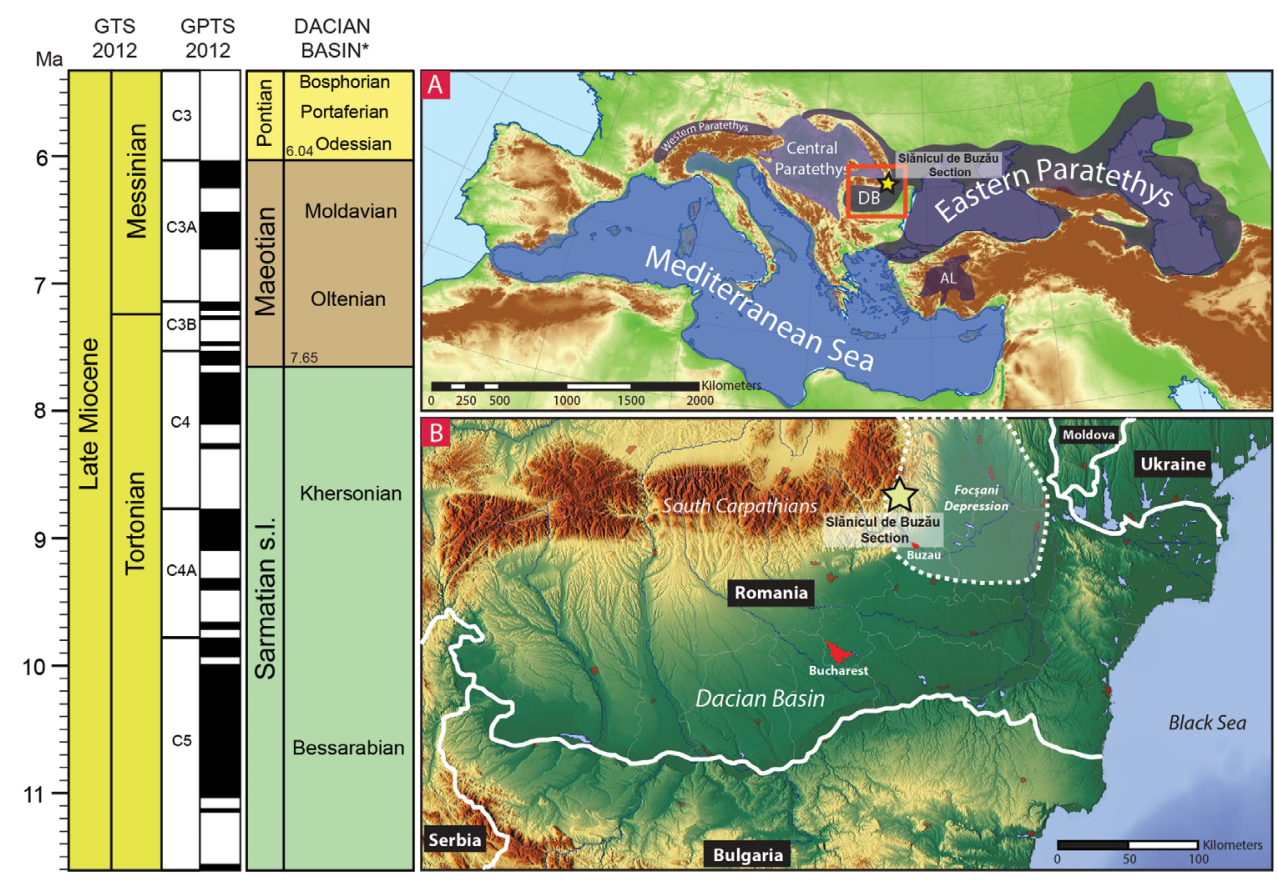

Figure 1.1 Location map of the Slănicul de Buzău section and time scale. Columns from left to right: Global time scale (GTS) and Geomagnetic polarity time scale (GPTS) (Hilgen et al., 2012) and the Dacian Basin regional boundaries. The age constraints for the regional boundaries: the Khersonian-Maeotian boundary - 7.65 Ma (Palcu et al., 2019b), the Maeotian-Pontian boundary (Krijgsman et al., 2010; Stoica et al., 2013). Position of the section in relation to: A. Paratethys; B. Dacian Basin. Abbreviations: DB Dacian Basin, AL - Anatolian lakes. The present-day Dacian Basin (the map base is taken from www. maps-for-free.com). 
2010). This spectacular late Miocene event had an enormous impact on the regional landscapes and ecosystems of the Mediterranean region (Roveri et al., 2014a), but its impact on the Paratethys appeared to be relatively limited (Krijgsman et al., 2010; Stoica et al., 2013; La Vara et al., 2016; van Baak et al., 2017). It is even more likely that Paratethys exerted a strong influence over the events in the Mediterranean through its fresh(er) water outflow (Marzocchi et al., 2016; Stoica et al., 2016; Grothe et al., 2018).

In contrast, profound sea-level changes and associated turnovers in water chemistry and faunal associations took place in Paratethys during the late Tortonian-early Messinian (Khersonian-Maeotian) (Kojumdgieva et al., 1989; Popov et al., 2010; Palcu et al., 2019b). Prominent unconformities exist in the Dacian Basin (Palcu et al., 2019b) and on the coast, shelf and in the deepwater of the Black Sea (Tari et al., 2015; Golovina et al., 2019), which requires a shift of attention towards the Khersonian-Maeotian events.

During the late Miocene, the Dacian basin was mostly a silled embayment, and a western branch of the Euxinian (Black Sea) Basin (Fig. 1.1) and their palaeoenvironmental evolutions were tightly linked. The Dacian Basin formed in the foreland of the Carpathians and accumulated a remarkable sedimentary record due to very high rates of late Miocene to Pliocene subsidence and deposition (0.6-1.5 m/kyr) (Matenco et al., 2003; Tărăpoancă et al., 2003; Vasiliev et al., 2004; Jipa and Olariu, 2009). Foreland propagation of thrusting in the Quaternary uplifted part of the late Miocene to Pliocene foreland basin infill, generating excellent exposures in the SE Carpathians that enable high-resolution palaeoenvironmental reconstructions.

In this paper, we focus on the late Tortonian-early Messinian (Khersonian-Maeotian) interval in the Dacian Basin, in particular on the Slănicul de Buzău section. We integrate sedimentary facies analyses with palaeoecological information from molluscs and microfauna and provide palaeomagnetic age constraints. The main aim is to document the palaeoenvironmental changes occurring in the Dacian Basin between the Khersonian (Tortonian) and Pontian (Messinian) Paratethyan base-level changes.

The Slănicul de Buzău section is located in the Romanian southeast Carpathians near the Focşani Depression - one of the main depocentres in the Carpathian foreland (Fig. 1.1B and 1.2). It represents the thickest and best-exposed succession of Miocene to Pleistocene sediments in the Dacian Basin (Motas et al., 1966; Dumitrescu et al., 1970) that was the subject of several earlier studies, e.g. with a focus on general palaeogeographic characteristics (Jipa and Olariu, 2009), regional geodynamic evolution (Dupont-Nivet et al., 2005; Vasiliev et al., 2009), and palaeoenvironmental changes in the Pontian (Snel et al., 2006; Grothe, 2016), Dacian (Jorissen et al., 2018) and Romanian (van Baak et al., 2015b). However, the palaeoenvironmental evolution during the Khersonian-Maeotian remains under-investigated. 


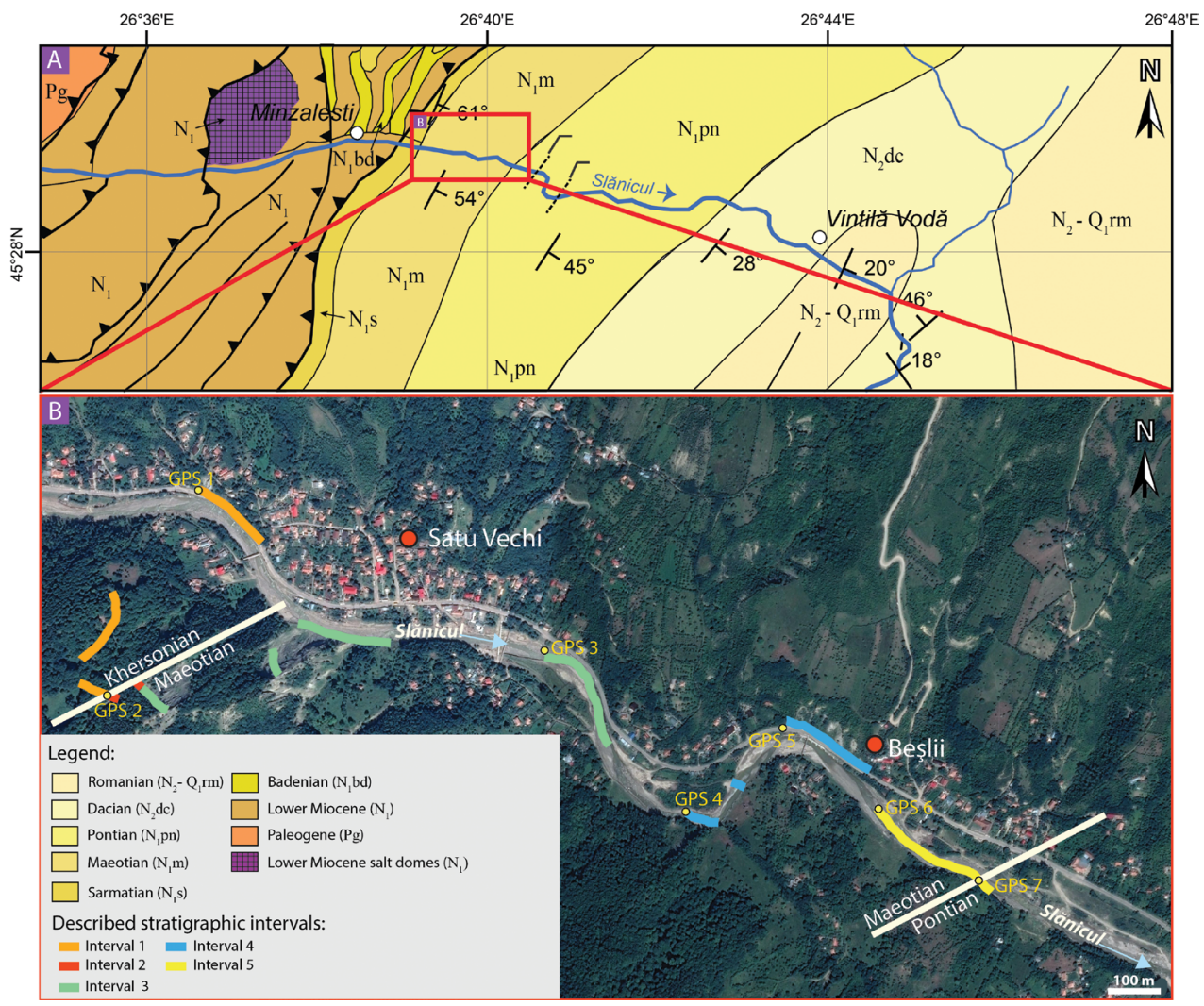

Figure 1.2 Geological setting of the studied section. A. Geological map (Motas et al., 1966; Dumitrescu et al., 1970); B. Position of the studied units of the Slănicul de Buzău area.

\subsection{Geological setting}

\subsubsection{The Dacian Basin as a part of the Eastern Paratethys}

The Dacian Basin is a foreland basin that formed in the middle Miocene at the foot of the Eastern and Southern Carpathians (Fig. 1.1B). It was part of the Paratethys Sea (Matenco et al., 2003; Jipa and Olariu, 2009; ter Borgh et al., 2014), which was a Eurasian sea that extended from the Alps in the West to the Aral Sea in the East (Laskarev, 1924; Rögl, 1999; Schulz et al., 2005) (Fig. 1.1A).

After the Eocene-Oligocene, Paratethys was continually shrinking in size (Rögl, 1999; Schulz et al., 2005). In the late Miocene, the formation of the Carpathian arcuate belt invoked a final separation of the Paratethys into two parts - the Eastern Paratethys (Euxinian, Caspian and Dacian Basins) and the Central Paratethys (Pannon Lake) (Tărăpoancă et al., 2003; Schmid et al., 2008; Vasiliev et al., 2010; ter Borgh et al., 2013; ter Borgh et al., 2014). 
The evolution of these Paratethys basins was inextricably determined by their numerous sea-level variations caused by an intricate interplay between climate fluctuations and tectonics (De Leeuw et al., 2010; Leever et al., 2010; Popov et al., 2010; Palcu et al., 2015; De Leeuw et al., 2018; Palcu et al., 2019b; Simon et al., 2019). Consequently, connections between basins opened and closed repeatedly. Base level, salinity and implicitly fauna and ecosystems were actively controlled by a filigreed balance between precipitation and evaporation as well as by the dynamics of the gateways to the open ocean (Leever et al., 2010; Karami et al., 2011; Vasiliev et al., 2015; Simon et al., 2019). Any disturbances in these parameters caused marked palaeoenvironmental responses (Palcu et al., 2015; Mandic et al., 2019).

In its evolution, the Dacian Basin went through three main stages: 1) The late middle Miocene-mid-late Miocene interval with brackish to polyhaline water environments and the most extensive connectivity with the Euxinian (Black Sea) Basin (Palcu et al., 2017); 2) The mid-late Miocene-mid-Pliocene interval with changing salinity from brackish to freshwater and restricted connectivity with the Euxinian Basin (Stoica et al., 2013); 3) The mid-PliocenePleistocene interval, in which the basin became overfilled and accumulated fluvial and limnic deposits (Jipa and Olariu, 2009; van Baak et al., 2015b; Jorissen et al., 2018; Matoshko et al., 2019).

\subsubsection{Regional stages and chronostratigraphy}

In the Black Sea and Dacian Basin region, the late Miocene regional time scale comprises the Bessarabian, Khersonian (both part of Sarmatian s.l.), Maeotian and Pontian regional stages (Fig. 1.1) (Piller et al., 2007; Hilgen et al., 2012). To clarify the time frames of our research and to avoid misunderstanding among non-regional researchers, we briefly explain the Eastern Paratethys regional stages here.

The Sarmatian stage was introduced by Suess (1866). The Sarmatian is used in both the Central and Eastern Paratethys, albeit with different durations and biostratigraphic divisions. In our study, we use a subdivision of the Sarmatian into three substages generally applied to the Eastern Paratethys: Volhynian (Lower), Bessarabian (Middle) and Khersonian (Upper). The base Sarmatian boundary (Badenian-Sarmatian) in the Dacian Basin was magnetostratigraphically dated at $12.65 \mathrm{Ma}$ and correlated to chron C5Ar.1r (Palcu et al., 2015).

During the Sarmatian, the Eastern Paratethys became isolated from the open ocean undergoing a consequent gradual extinction of marine forms inherited from the Badenian (Iljina et al., 1976). The most pronounced palaeoenvironmental changes happened in the Khersonian when the Eastern Paratethys endured a series of marked sea-level drops (Tugolesov et al., 1985; Popov et al., 2006; Palcu et al., 2019b). This resulted in disconnection of its various subbasins, and extinction of the last marine assemblages dominated by oligo-, mesohaline molluscs of Chersonimactra sp. (Iljina et al., 1976; Kojumdgieva et al., 1989; Paramonova, 1994). In the Black Sea (Euxinian Basin), the Khersonian-Maeotian boundary has been dated 
magnetostratigraphically (Trubikhin, 1989; Radionova et al., 2012) and cyclostratigraphically (Rybkina et al., 2015) at 7.6 Ma (correlation to C4n.1n) and in the Dacian Basin (correlation to C4n.1r - C3Br.2r chrons) it was recently dated at 7.65 Ma (Palcu et al., 2019b).

The Maeotian stage was named by Andrusov (1899) and divided into two substages - Oltenian and Moldavian in the Dacian Basin (Wenz, 1942; Roshka, 1973; Vereshchagin, 1982). The Maeotian stage started with a marked transgression that ended the Khersonian lowstand, increased connectivity between the Euxinian, Caspian and Dacian basins, and led to the spread of brackish water biota (Popescu, 2006; Palcu et al., 2019b). In the Dacian Basin, the lower Maeotian (Oltenian) shows an alternation of molluscs tolerant to a range of different salinities: freshwater unionids and neritids (Unio, Theodoxus), freshwater to brackish water dreissenids and marine Dosinia, Abra, Ervilla (Wenz, 1942; Iljina et al., 1976). The upper Maeotian (Moldavian) is defined by the wide distribution of freshwater and slightly brackishwater gastropods such as Theodoxus stefanescui and Pontohydrobia ossovinarum, occasionally in combination with Andrusoviconcha modiolopsis (Wenz, 1942; Roshka, 1973; Iljina et al., 1976). The Maeotian is followed by the Pontian stage, which starts slightly before the onset of the MSC in the Mediterranean (Krijgsman et al., 2010; Stoica et al., 2013). The Maeotian-Pontian boundary is characterised by a short influx of poly-, mesohaline microfauna assemblages dominated by Ammotium, Ammonia, Streptochilus and Tenuitellina and followed by the occurrence of the Lower Pontian molluscs Paradacna, Eupatorina and Pontalmyra (Roshka, 1973; Iljina et al., 1976; Vereshchagin, 1982; Stevanovic et al., 1989; Snel et al., 2006; Popov et al., 2016; Stoica et al., 2016).

The Maeotian-Pontian boundary has been dated cyclostratigraphically at $\sim 6.1 \mathrm{Ma}$ in the Black Sea and Caspian Sea (Chang et al., 2014; van Baak et al., 2016; Rostovtseva and Rybkina, 2017), and magneto-biostratigraphically at 6.04 Ma in the Dacian Basin (slightly below C3r C3An.1n polarity switch) (Krijgsman et al., 2010; Stoica et al., 2013).

\subsection{Material and methods}

\subsubsection{The Slănicul de Buzău section}

The Khersonian-Pontian interval in the Slănicul de Buzău valley is located in the NW flank of a syncline (Fig. 1.2A) that determines a gradual flattening of the bedding plane from $112^{\circ} / 60^{\circ}$ $\mathrm{SE}$ at the base of the section to $120^{\circ} / 48^{\circ} \mathrm{SE}$ at the top of the section. The studied interval is 1380 $\mathrm{m}$-thick, with $700 \mathrm{~m}$ being well exposed (Fig. 1.3). The described interval begins in Khersonian deposits exposed on the left side of Slănicul river, along the Mânzăleşti - Vechi road (GPS $\left.45^{\circ} 29^{\prime} 18.74^{\prime \prime} \mathrm{N} ; 6^{\circ} 39^{\prime} 10.30^{\prime \prime} \mathrm{E}\right)$ and ends in the Pontian deposits on the right side of the same

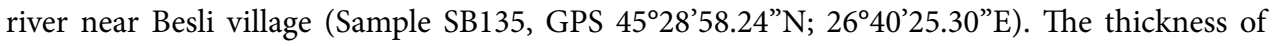
the section as well as the non-exposed intervals were measured in the field and subsequently corrected using satellite maps, GPS points and bedding parameters. 


\section{CHAPTER 1}

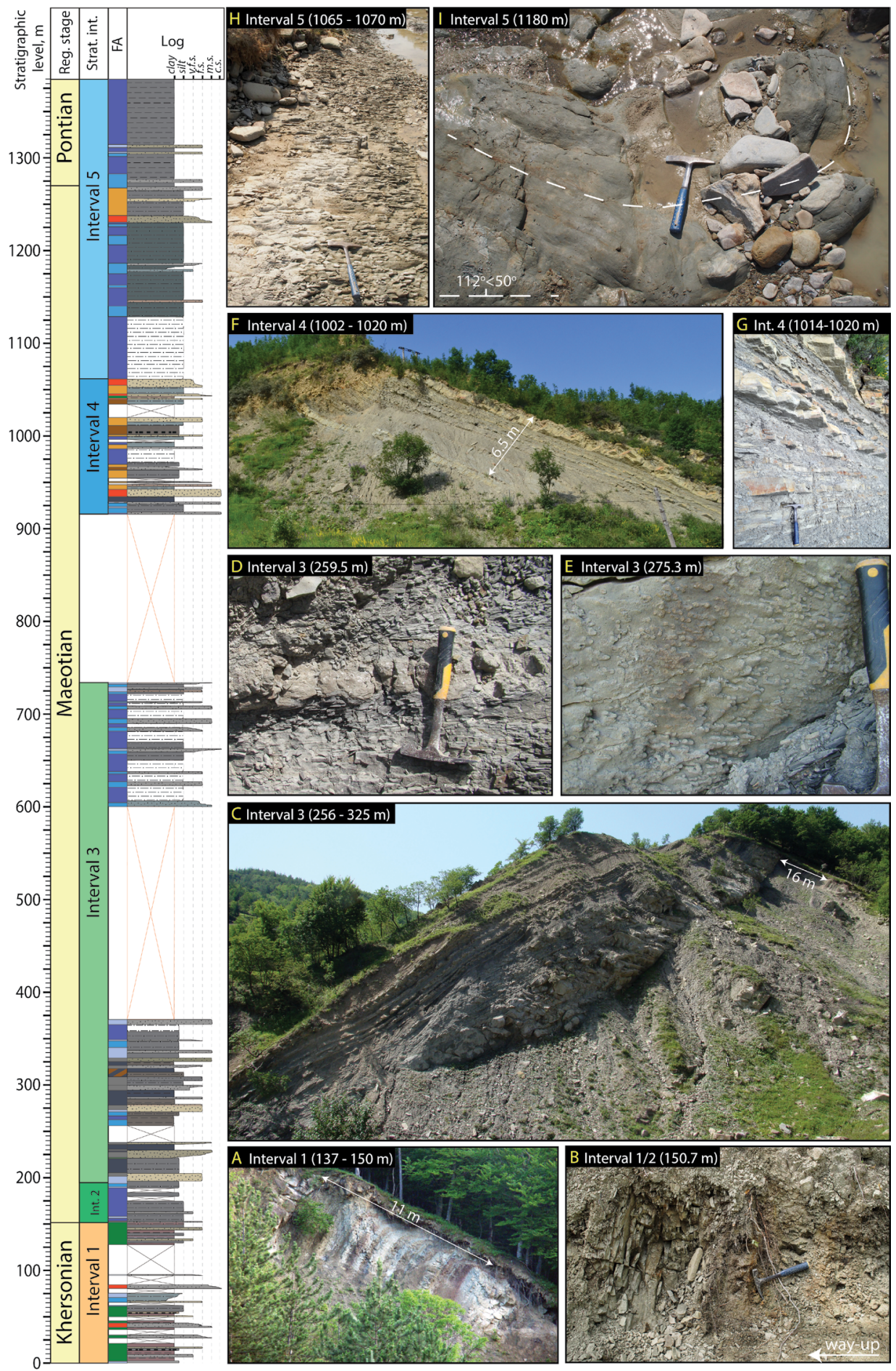


Figure 1.3 (previous page) General log of the upper Khersonian-Maeotian-lowermost Pontian interval of the Slănicul de Buzău section. Green arrows - mollusc samples, blue arrows - microfauna samples. A. Floodplain, continental environments of Stratigraphic Interval 1 (SI1); B. Khersonian-Maeotian Boundary. Maeotian fissile siltstones cover Khersonian red palaeosoils. Top to the left.; C. Thick barrier island sandstone body followed by thin washover sandstones (SI3); D. Storm layer occurring in the offshore transition environment with chaotically distributed shells of Viviparus moldavicus (mollusc sample 99); E. Traces of Diplocraterion habichi on the base surface of the barrier island sandstone (SI 3); F. Shallowing upwards succession of deltaic deposits (SI 4); G. Alternation of current-ripple cross-laminated sandstone and mudstone in delta front environment (SI 4); H. Offshore thinly-laminated clays of SI 5; I. Slump within the offshore clays of the SI 5 . The colour meaning in the facies association column is shown in the legend of Figure 1.4.

\subsubsection{Sedimentology}

Sedimentological study of the Khersonian-Maeotian interval in Slănicul de Buzău is based on field observations that were focused on the description of lithofacies (lithology, grainsize, colour, sedimentary structures) and associated trace fossils. The descriptive terminology followed the field guide of Tucker (2012), while the general facies concept is based on Miall (1996). Later, the commonly occurring lithofacies were combined into nine distinct facies associations (Table 1.1) following the concept of Collinson (Collinson, 1969; Posamentier and Walker, 2006). Depositional environments were attributed to these facies associations based on sedimentological reasoning and a comparison with well-known literature examples (Table 1.1). Sequence stratigraphic interpretations follow Catuneanu et al. (2009), were developed at thirdorder scale (ca. $1 \mathrm{Ma}$ ) and were deliberately kept fairly basic given that we only discuss results from a single section.

\subsubsection{Biostratigraphy}

Thirty-five mollusc samples with a weight of about $1 \mathrm{~kg}$ were first handpicked for larger specimens to prevent their fragmentation. The residues were then washed and sieved through a sieve with a $1 \mathrm{~mm}$ mesh size. Identifications, taxonomic classification and palaeoecological interpretations are based on (WoRMS Editorial Board; Wenz, 1942; Kojumdgieva, 1969; Stevanovic and Iljina, 1982; Stevanovic and Paramonova, 1983; Nevesskaja et al., 1993; Paramonova, 1994; 1997; 2013). For the investigation of microfauna, forty-five samples were washed and sieved through a sieve with $63 \mu \mathrm{m}$ mesh size following a standard micropalaeontological approach (Stoica et al., 2013). Preparation, identification and photographing of the mollusc fauna were performed at the Natural History Museum (Vienna, Austria), while the microfauna has been processed at the University of Bucharest (Romania) (Supplementary 1). 


\subsubsection{Magnetostratigraphy}

Palaeomagnetic measurements were performed in the Paleomagnetic laboratory "Fort Hoofddijk", Utrecht University, the Netherlands. For palaeomagnetic investigations, 139 stratigraphic levels were sampled with a portable drilling machine equipped with a diamond crone, water pump and a petrol generator as power supply. From each level, two standard oriented cylindrical samples were taken. A local declination correction of $5^{\circ}$ (www.ngdc.noaa. gov) was added to all measurements to compensate for secular variation. In order to retrieve the Characteristic Remanent Magnetization (ChRM), 60 samples were demagnetised thermally (TH), 61 samples in alternating field (AF), and for 18 samples, both techniques were applied. During thermal demagnetization, samples were stepwise heated with increments of $30-40{ }^{\circ} \mathrm{C}$ up to $680^{\circ} \mathrm{C}$, or to a lower temperature if the remanent magnetization became lower than 10 $\%$ of its initial value. After each temperature step, samples were measured in multiple positions on a horizontal 2G Enterprise DC SQUID cryogenic magnetometer (noise level $3 \times 10^{-12} \mathrm{Am}^{2}$ ). Measurements in alternating field (AF) were performed on a robotised handler controller attached to a horizontal 2G Enterprise DC SQUID cryogenic magnetometer (Mullender et al., 2016). Samples were gradually demagnetised in alternating field (AF) from 0 to $100 \mathrm{mT}$ with increments of 2-20 mT. In addition, to determine magnetic carriers, thermomagnetic properties in air of 3 samples were measured on a horizontal type Curie balance (noise level $5 \times 10^{-9} \mathrm{Am}^{2}$ ) (Mullender et al., 1993). The measured magnetic directions were interpreted using the online platform Paleomagnetism.org (Koymans et al., 2016). All interpreted data are included in the manuscript (Supplementary 2-4) and can be uploaded to Paleomagnetism.org. For correlation of the acquired polarity pattern, we used the Global Polarity Time Scale (GPTS) (Hilgen et al., 2012).

\section{$1.4 \quad$ Results}

\subsubsection{Stratigraphic intervals and associated fauna}

The Khersonian to Maeotian sedimentary record of the Slănicul de Buzău section is highly variable. Nine typical facies associations were recognised (Table 1.1; Fig. 1.4). The section was moreover divided into five stratigraphic intervals (Fig. 1.3) for which the sedimentary facies associations, microfauna and mollusc fauna are discussed below. A discussion per biostratigraphic interval was preferred over a discussion per depositional unit because it facilitates comparison with other contemporaneous Paratethys records.

Table 1.1 (opposite and following pages) Characteristics of lithological facies associations recognised in Khersonian-Maeotian interval of the Slănicul de Buzău section. 
FA 1: Grey, bluish grey, fissile, thinly $(1-2 \mathrm{~mm})$ parallellaminated claystones and siltstones, containing sporadic up to $5 \mathrm{~cm}$-thick beds of grey muddy finegrained sandstone lacking sedimentary structures. FA1 usually covers FA3 with a sharp contact. Gradually passes upwards into FA2.

FA2: Grey, thinly-laminated siltstones with interbedded sandstones. Sandstones occur as sharp-based (sporadic gutter casts) single beds $(<2 \mathrm{~m}$ ) with lowangle cross lamination, soft-sediment deformation structures, climbing-ripple cross-lamination sometimes finished by a wavy top surface, or alternatively, occur as packages $(<2 \mathrm{~m})$ of closely interbedded hummocky cross-stratified muddy sandstones. Typical ichnotraces belong to Diplocraterion - U-shape traces forming sets of double-spot patterns on the basal surface of sandstone beds, Bioturbation Index $(B I)=1-2$. FA2 is usually underlain by

FA1 and gradually passes upwards into FA3.
Offshore. Relatively deep-water and low-energy offshore zone as indicated by the predominantly fine grain-size and thin lamination. Similarly interpreted facies are known from the open marine shelf in the Upper Cretaceous of the Back Tongue (Yoshida, 2000) and the Turonian Ferron Sandstone (Fielding, 2010), Utah and from the Late Quaternary deposits of the Po Delta (Amorosi et al., 2003; Amorosi et al., 2016).

Offshore transition zone between fair-weather-and storm-wave base in line with storm-induced hummocky cross-stratification (Raaf et al., 1977; Cheel, 1978; Dott and Bourgeois, 1982). Soft-sediment deformation structures accompanied by climbing-ripple crosslamination in single-bed sandstones point at a rapid deposition from sediment-laden unidirectional flows resulted from exceptional storm events (Ashley et al., 1982; Bhattacharya and MacEachern, 2009; Oliveira et al., 2011). Traces of Diplocraterion commonly belong to Skolithos ichnofacies, which is widely distributed in nearshore areas (MacEachern and Bann, 2008). Similarly interpreted facies occur in the Cretaceous Sego Sandstone in Utah (van Cappelle et al., 2016), are known as lower shoreface in the Neogene cores of the Eastern Venezuela Basin (Buatois et al., 2012), or as distal lower shoreface in the Star Point Sandstone in Utah (Forzoni et al., 2015).
FA3: 1-3 m-thick coarsening- and thickening-upwards packages of grey, yellowish-grey, fine- to mediumgrained sandstone. The sandstone packages consist of very thinlybedded (3-4 cm) wave-ripple crosslaminated beds that gradually thicken up into a very thick bed $(<2 \mathrm{~m})$ with wave-ripple marks. Locally, some of the beds are structureless or have a faint parallel-or low-angle cross lamination. There are also some thin oolite beds. Bioturbation mostly occurs in the uppermost beds. It generally comprises elements as Skolithos (simple vertical straight shafts, $\varnothing<10$ $\mathrm{mm}$ ) and Ophiomorpha (vertical to horizontal shafts with bioglyphs, $\varnothing \sim 40 \mathrm{~mm})(B I=3-4)$, locally with smaller scale vertical burrows in mudground, roughly attributed to Glossifungites $(B I=2-3$, bivalve borings, polychaete burrows). FA3 is usually underlain by FA2 with gradual contact and typically succeeded by FA4, but also by FA1, FA2.

FA4: 1 to 6 m-thick, coarsening-upwards beds of grey structureless or low-angle crosslaminated sandstone with occasional convolute structures. In the facies association order FA3 $>F A 4>F A 5$, the FA3 to FA4 transition is gradational and coarsening upwards, while the transition from FA4 to FA5 is sharp, with a
Shoreface. Frequent wave-ripple cross-bedding suggests deposition within the fair-weather wavebase interval. Gradual thickening and coarsening upward and presence of FA4 on top of FA3 indicate progradation. Oolites formed on shoals, tidal bars or beaches (Flügel, 2010). Skolithos ichnofacies (including elements Skolithos, Ophiomorpha and Planolites) is typical for the near-shore zone and a noncohesive, shifting substrate (Gérard and Bromley, 2008; MacEachern and Bann, 2008). Glossifungites mostly occurs in fairly turbulent waters on muddy firmgrounds drilled or scraped by bivalves or worms (Seilacher, 2007). Similar deposits were distinguished as shoreface facies in the Blackhawk Fm, Utah (Yoshida, 2000), as upper shoreface deposits in the Neogene of the Eastern Venezuela basin (Buatois et al., 2012), and as middle and upper shoreface in Reading (1996) and Tamura (2012).

Barrier island. A longshore-prograding sandstone body, which is separated from the mainland by lagoons and marshes (McCubbin, 1982; Reading, 1996) and has wave-dominated shoreface environments on the basin side (Hampson et al., 2009; Kieft et al., 2010). Low-angle lamination formed by shore-normal oscillatory motion

(Continued on next and following pages) 


\section{CHAPTER 1}

surface covered with broken and irregularly distributed shell fragments, locally mixed with ooids. In the facies association order FA5 $>$ FA4 $>$ FA3, FA4 has a sharp, undulating and erosive base, with frequent traces of Diplocraterion (BI = 3-4) (Fig. 3C, E) (Bann et al., 2004; Gérard and Bromley, 2008). Locally, this base is covered with small irregularly shaped holes $(<3 \mathrm{~cm})$, which are probably relicts of mud clasts and contains some single fragments of fossilized wood. The FA4 to FA3 transition is gradual and fining up.

FA5: Dark-grey to black organic-rich thinly-parallellaminated claystone (carbonaceous shale), in intervals 0.5-10 $\mathrm{m}$-thick, interbedded with rare thin $(<0.3 \mathrm{~m})$ beds of grey fine-grained sandstone with planar cross-lamination and thin $(<0.2 \mathrm{~m})$ beds of grey fissile material are very abundant. Ophiomorph a traces (BI $=2$ ) were observed in one of the grey silty sandstones. FA5

overlies FA4 with a non-erosive but sharp contact and is overlain by FA4 with a strongly erosive contact. mudstone. Wood fragments and dispersed organic

(McCubbin, 1982). In shallowing trends, the barrier occurs between shoreface and lagoon deposits. In deepening trends, the barrier covers lagoon deposits and passes upwards into shoreface deposits (McCubbin, 1982; Chentnik et al., 2015). Also known from the Middle Jurassic Brent Group of the northern North Sea (Went et al., 2013).

Back-barrier lagoon, situated behind coeval spits and barriers (Hampson et al., 2009; Kieft et al., 2010; Kieft et al., 2011; Buatois et al., 2012; Chentnik et al., 2015) and strongly influenced by freshwater and terrestrial organic matter input (Allen and Johnson, 2011). Non-periodic thin sandstone beds reflect storm washover (Hayes and FitzGerald, 2013; Chentnik et al., 2015). Ophiomorpha suggests marine origin (McCubbin, 1982). Also known from the Mid Jurassic of the South Viking Graben (Kieft et al., 2010), mid-to-late Jurassic of the North Sea Graben rift basin (Hampson et al., 2009), Upper Cretaceous Straight Cliffs Fm, Utah (Allen and Johnson, 2011), and Late Pleistocene-Holocene of the Po Delta (Amorosi et al., 2003).

FA6a: Thinly-bedded $(<0.03 \mathrm{~m})$ grey laminated siltstones with interbedded brownish-grey massive mudstones in packages up to $2 \mathrm{~m}$ thick. Locally, mudstones are inversely-graded, gradually passing into fine-grained structureless sandstones. The latter ones contain some shell debris and upwards, with a gradual contact develop back into mudstones.

FA6b: Brown, bluish-grey fissile thinly-parallellaminated to massive mudstones with rare thin $<<$ $0,2 \mathrm{~m}$ ) beds of fine-grained muddy sandstone with undulating laminae and soft-deformation structures in packages up to $10 \mathrm{~m}$. No bioturbation was found. FA 6 (prodelta) is delimited by FA 7 (delta front) with a gradual transition or overlies FA1 (offshore) (Figs. 8, 10) also with a gradual transition.

FA7a: 10 m-thick heterolithic packages of sharply bounded beds $(<0.3 \mathrm{~m})$ of brown muddy very finegrained sandstone and brown, bluish-grey siltstones (Fig. 3G). Sandstone beds are planar parallel-laminated or trough cross-laminated with current-ripple marks. Thicker sandstone interbeds are sometimes low-angle cross-laminated and have sole structures at the basal surface. Sharp-bounded sandstone beds are locally underlain by siltstones with soft-sediment deformation
Prodelta. Deposition of sandy mudstone and sandstones at times of larger outflow and suspension fallout of mud during stagnant periods (Fielding, 2010). Inverse grading in some sandstone beds may suggest hyperpycnal flows (Mulder et al., 2003; Bhattacharya and MacEachern, 2009) during waxing river discharge periods, whereas the normally-graded beds reflect waning discharge (Mulder et al., 2003). Hyperpycnal flow may also be induced by storms (Bhattacharya and MacEachern, 2009), in line with associated shell debris and soft-deformation structures. Weakly developed undulating lamination indicates a deceleration of uni-directional flow. The lack of bioturbation suggests physio-chemical stress, i.e. prodelta changes in salinity and sediment input (MacEachern et al., 2005). Similarly interpreted facies are known from the Turonian Ferron Notom Delta Complex, Utah (Zhu et al., 2012), and the Shivugak Bluffs, Alaska (van der Kolk et al., 2015).

Delta front. Intervals with interbedded sandstones and mudstones reflect the distal delta front, whereas thick sandstones reflect the proximal delta front. Granulometry is strongly dependent on river discharge intensity. Coarser sand beds reflect heavily sedimentloaded outflow events, while mudstones indicate more stagnant periods (Fielding, 2010). Parallel lamination, planar crosslamination and trough cross-lamination formed in the upper flow regime (Miall, 1996). Lowangle 
structures and, in the case of amalgamated bedding, the basal sandstone beds bear pillow structures.

FA7b: Similar to FA7a but with a thickening-upward trend in the sandstone beds resulting in a very thick $(<2 \mathrm{~m})$ sandstone at the top of each succession.

Structures change from low-angle cross-lamination at the bottom of the succession, through a structureless interval, to trough and current-ripple cross-lamination in the upper part. Mudstones below sandstones contain marked water-escape structures. Bioturbation is not clear $(B I=0-1)$. FA7 is typically underlain by FA6 with a transitional coarseningupwards contact and may be overlain either by FA6 with a transitional fining upwards contact or erosively by FA8.

FA8A: Erosionally-based, fining-upwards, mediumto fine-grained sandstone bodies up to $8 \mathrm{~m}$ thick, consisting of 2-3 beds of 1-4 $m$ thick that are amalgamated or separated by thin $(<0.01 \mathrm{~m})$ layers of grey mudstone. Sandstones have an undulated basal surface ( $<2 m$ wavelength, and $<0.4 m$ amplitude) with flow marks overlain by a breccia with rounded siltstone clasts up to $0.3 \mathrm{~m}$ in diameter. In the middle part, planar cross-lamination and some climbing ripples and mud drapes occur, while higher up there is large-scale sigmoidal, low-angle lamination, fading upwards and passing into thin planar cross-laminated sets with current ripples. There are fossilized wood fragments and plant debris, but no bioturbation.

FA8B: Similar to FA8A except for its base, which is conformable. The lower part of the sandstone body sometimes coarsens upwards. FA 8 overlies FA7 or FA5 with erosive contact. FA8 is covered by FA7 and FA6 with a gradual fining-upwards contact, by FA9 with a gradual contact or by FA1 with a sharp contact.

FA9: Packages of up to $10 \mathrm{~m}$ thick consisting of an alternation of reddish-brown, mottled, aggregate claystone in beds of 0.3-1 m and light-grey, yellowishgrey, structureless, locally fissile, marly mudstones and siltstones in beds of 0.2-0.4 m. Some of these mudstones contain Ammonia beccarii foraminifera. Occasionally, there are single beds of planar crosslaminated and current-ripple cross-laminated sandstones, 0.2-1 m thick,

which exclusively overlie grey mudstones. Where reddish mottled claystone beds overlie grey mudstone beds, the contact is irregular. In a single case, a 0.5 m-thick bed of bioclastic limestone built of Sarmatimactra shells was observed. Bioturbation is mostly absent or obscure, but rare rootlets and rhizoliths occur. FA9 is associated with FA3 and FA8. cross-lamination with current-ripple marks on bed tops demonstrates sand deposition in the lower flow regime. Infrequent massive sandstone beds with well-expressed soft-sediment deformation resulted from gravity flows (Oliveira et al., 2009), but the lack of gradation and structures precludes the distinction between hyperpycnal flows or turbidity currents. The lack of bioturbation is likely linked to fluctuations in salinity, in analogy with the

above-described prodelta facies. Similarly interpreted sediments are known from the Turonian Ferron Notom Delta Complex, Utah (Zhu et al., 2012) and the Shivugak Bluffs, Alaska (van der Kolk et al., 2015).

\section{Deltaic mouth bars ( $8 B$ ) and distributary} channels ( $8 A$ ) with progressively diminishing flow. Intraformational breccia as a result of bank collapse is a typical sign of highly-erosive distributary channels (Fielding, 2010; Buatois et al., 2012; Matoshko et al., 2016). The presence of plant debris and fragments of fossilized wood are the effect of erosive reworking of the floodplain. Thin interbedded mudstones likely point at an episodic cessation of the water flow during temporary channel abandonment (Fielding, 2010). Similarly interpreted facies are known from the Eocene Hecho Group of the South-central Pyrenean foreland basin (Cronin et al., 1998) and the Turonian Ferron Sandstone (Fielding, 2010).

\footnotetext{
Coastal plain. Grey mudstones formed due to suspension fallout from stagnant water on the floodplain while the ones containing foraminifera accumulated during periodic small scale transgressions on the coastal plain. The red mottled claystones on top suggest subaerial exposure and are interpreted as palaeosols (Nadon and Issler, 1997; Kraus, 1999; Scherer et al., 2015). Sandstone beds are interpreted as crevasse splays filling floodplain ponds. Similarly interpreted facies are known from the Surakhany Suite, South Caspian Basin (Vincent et al., 2010), the Tertiary Duchesne River Fm, Uinta Basin (Sato et al., 2018), the Aptian Barbalha Fm, Araripe Basin (Scherer et al., 2015) and Middle Moscovian of the Kladno-Rakovník Basin (Opluštil et al., 2015).
} 


\section{CHAPTER 1}

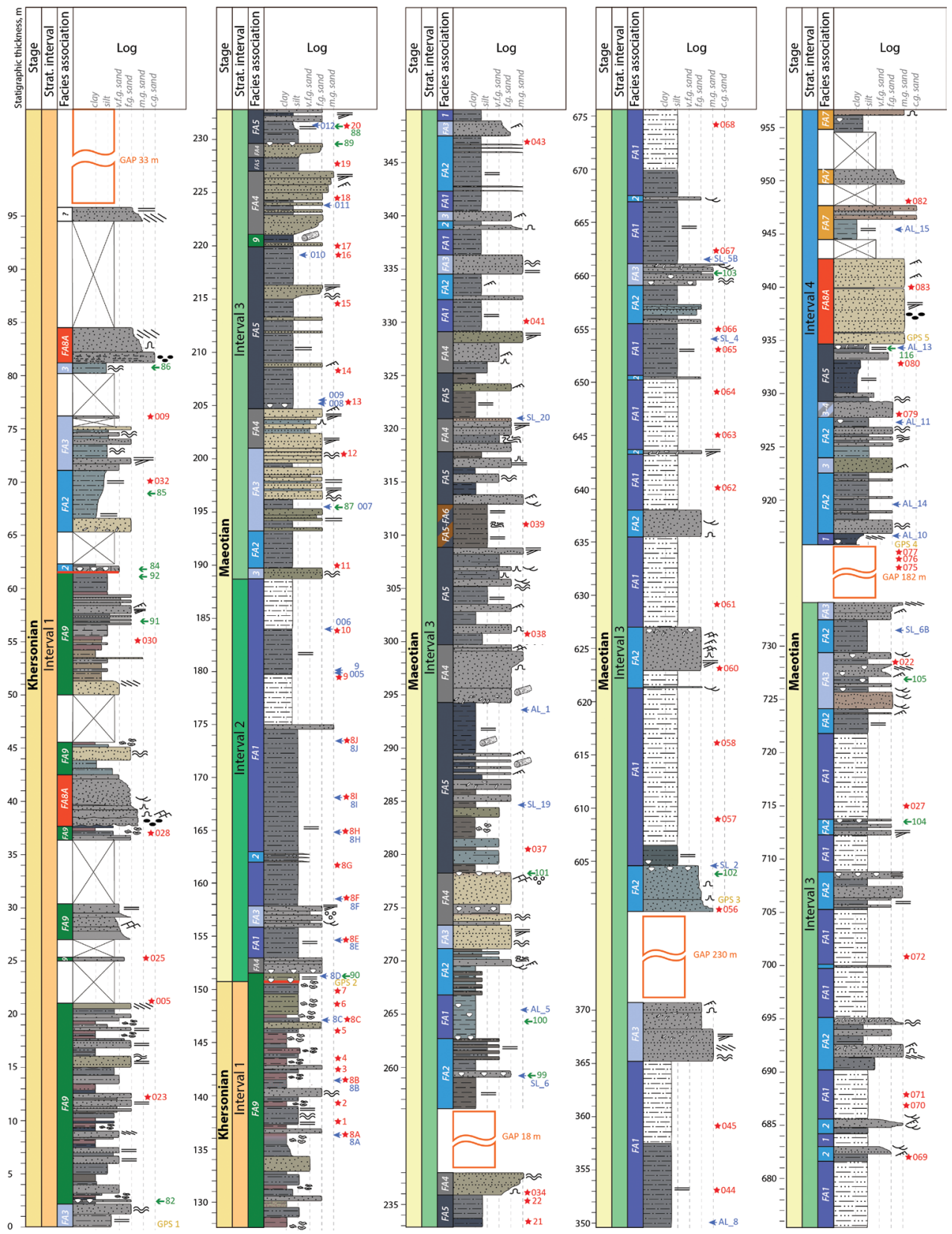

Figure 1.4 Detailed sedimentary log of the upper Khersonian-Maeotian-lowermost Pontian interval of the Slănicul de Buzău section with sampling points and sedimentary structures indicated. 

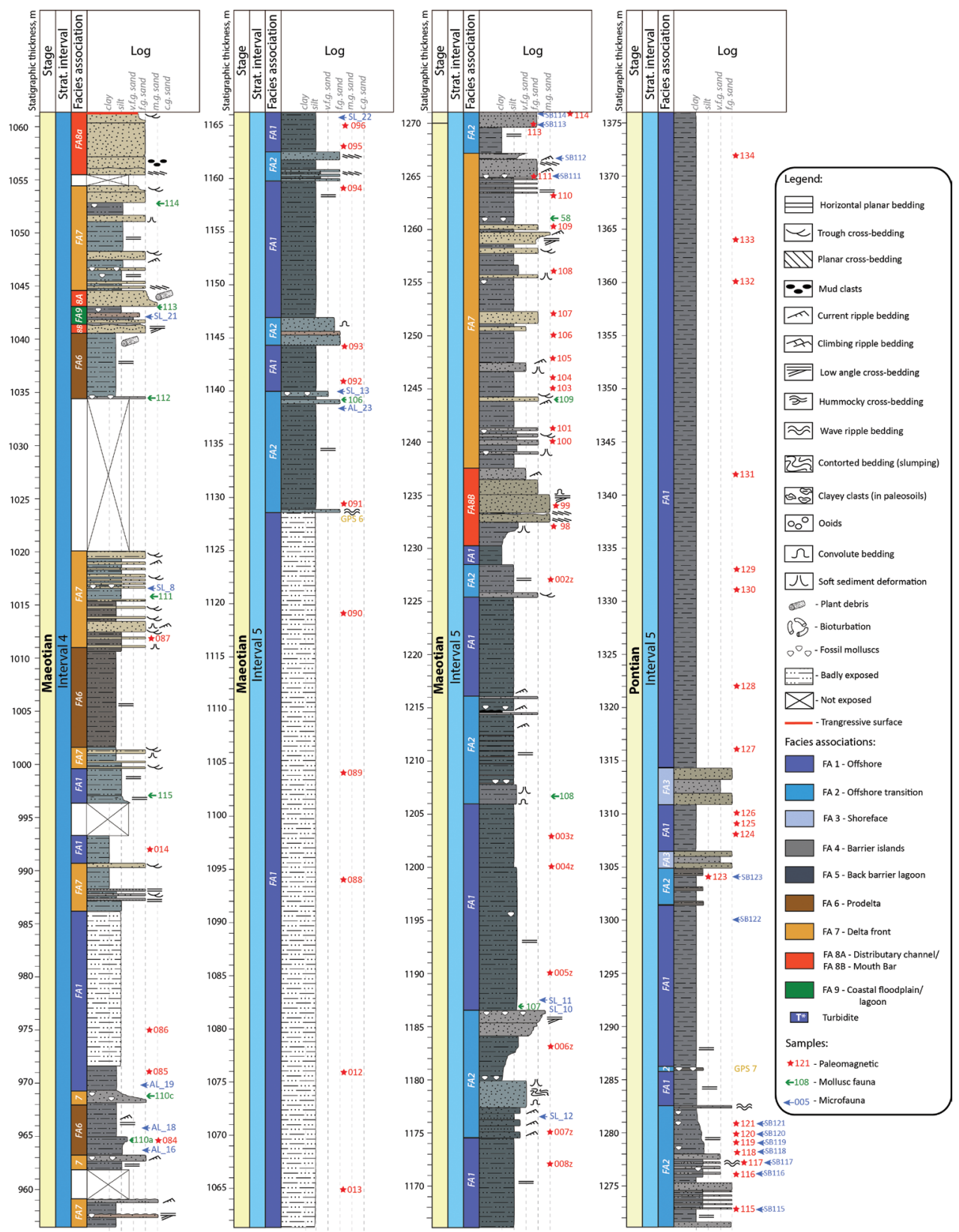

Figure 1.4 (continued). 


\subsubsection{Stratigraphic interval 1 - upper Khersonian}

Stratigraphic interval 1 consists of three lithologically distinct subintervals. The lower (0-61.2 $\mathrm{m}$ ) and upper (127.5-150.8 m) subintervals display sandstone - grey mudstone - red claystone alternations characteristic for FA9 (Fig. 1.3A, 4, Table 1.1). The middle subinterval $(61.2-127.5 \mathrm{~m})$ is more poorly exposed and consists of bioclastic limestones, claystones and sandstones attributed to FA2, FA3 and FA8 (Fig. 1.4; Table 1.1).

The mollusc fauna, collected in the lower and middle parts of SI1 is dominated by Chersonimactra caspia and locally also contains Coelogonia? sp. and/or Potamides? cf. disjunctus (Fig. 1.5, Table 1.2). At $56 \mathrm{~m}$, a specimen of Helix mrazeci has been found (Fig. 1.5, Table 1.2). The upper part of SI1 contains no molluscs.

The microfauna of SI1 has been studied only in its upper part (Fig. 1.6, 127.5-150.8 m), where there is a link between fauna and lithofacies: The grey mudstones contain abundant Ammonia beccarii benthic foraminifera, while the red and brownish claystones either have no fossils or contain oogonides of freshwater algae Nitellopsis sp., possibly Nitellopsis meriani (Fig. $1.7)$.

\subsubsection{Stratigraphic interval 2 - Khersonian - Maeotian transition}

Stratigraphic interval $2(150.7-188.7 \mathrm{~m})$ is dominated by claystones and siltstones of FA1 in combination with infrequent sandstones of FA3 and FA4 (Fig. 1.4, Table 1.1). It commences with yellow fissile siltstones that overlie the last red claystone of SI1 (Fig. 1.3B) and gradually develop into thickly-bedded grey low-angle cross-stratified sandstones attributed to FA4. Further up, the sandstone is sharply covered by thinly parallel-laminated siltstones of FA1. Slightly higher, at $156 \mathrm{~m}$, a second remarkable sandstone package with ooids is exposed, which we attribute to FA3 (Fig. 1.4; Table 1.1). The latter is also sharply covered by siltstones of FA1 that continue until the end of SI2.

The only shell bed of SI2 occurs at $151.5 \mathrm{~m}$ and is composed of a monospecific assemblage of Andrusoviconcha modiolopsis (Table 1.2). The micropalaeontological assemblage of SI2 is dominated by benthic calcareous Ammonia beccarii foraminifera, associated with rare agglutinated foraminifera like Miliammina subvelatina, Ammotium sp. (Fig. 1.6, 1.7). Beside foraminifera, we identified the brackish ostracods: Euxinocythere (Maetocythere) praebosqueti, Euxinocythere (Maetocythere) maeotica, Loxoconcha rimopora, L. muelleri, Hemicytheria maeotica and Xestoleberis maeotica (Fig. 1.6, 1.7). We also noticed an abundance of the euryhaline species Cyprideis torosa, as well as a few bryozoan fragments of Tamanicella lapidosa (Fig. 1.7).

\subsubsection{Stratigraphic interval 3 - lower Maeotian}

Stratigraphic interval 3 is characterised by an alternation of sandstones and organic-rich claystones and can be subdivided into two subintervals: A lower part (188-329 m) with a 


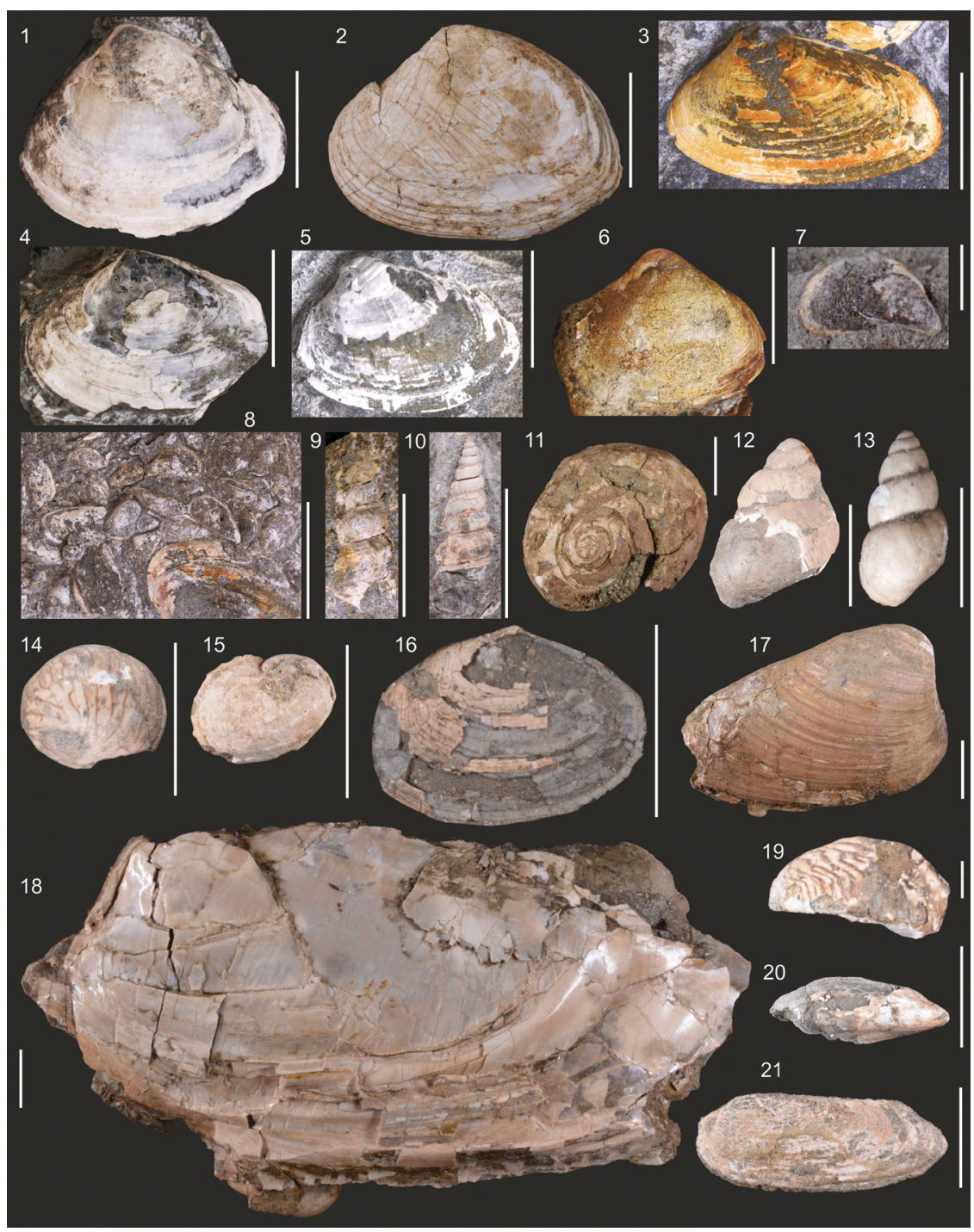

Figure 1.5 Sarmatian s.l. (1-11) and Maeotian (12-21) molluscs from the Slănicul de Buzău section: 1-8 and 16-21 bivalves, 9-15 gastropods. Scale bars $10 \mathrm{~mm}$, except for 7, 13 and $19-2 \mathrm{~mm}$. 1-5. Chersonimactra caspia (samples $84-1$ and 4, $91-2$, and $92-3$ and 5); 6. Chersonimactra bulgarica (sample 82); 7-8. Coelogonia? sp. (aff. navicula) (sample 86); 9-10. Potamides? sp. (cf. disjunctus) (sample 86); 11. Helix mrazeci (sample 91); 12. Viviparus moldavicus (sample 110b); 13. Hydrobia vitrella (sample 104); 14. Theodoxus stefanescui (sample 110b); 15. Velutinopsis sp. (sample 110b); 16. Mactra superstes (sample 102); 17. Sinzowinaia subhoernesi (sample 116a); 18. Hyriopsis cf. krejcii (sample 111); 19. Andrussoviconcha modiolopsis (sample 102); 20. Dreissena polymorpha (sample 110b); 21. Dreissenomya rumana (sample 109). 


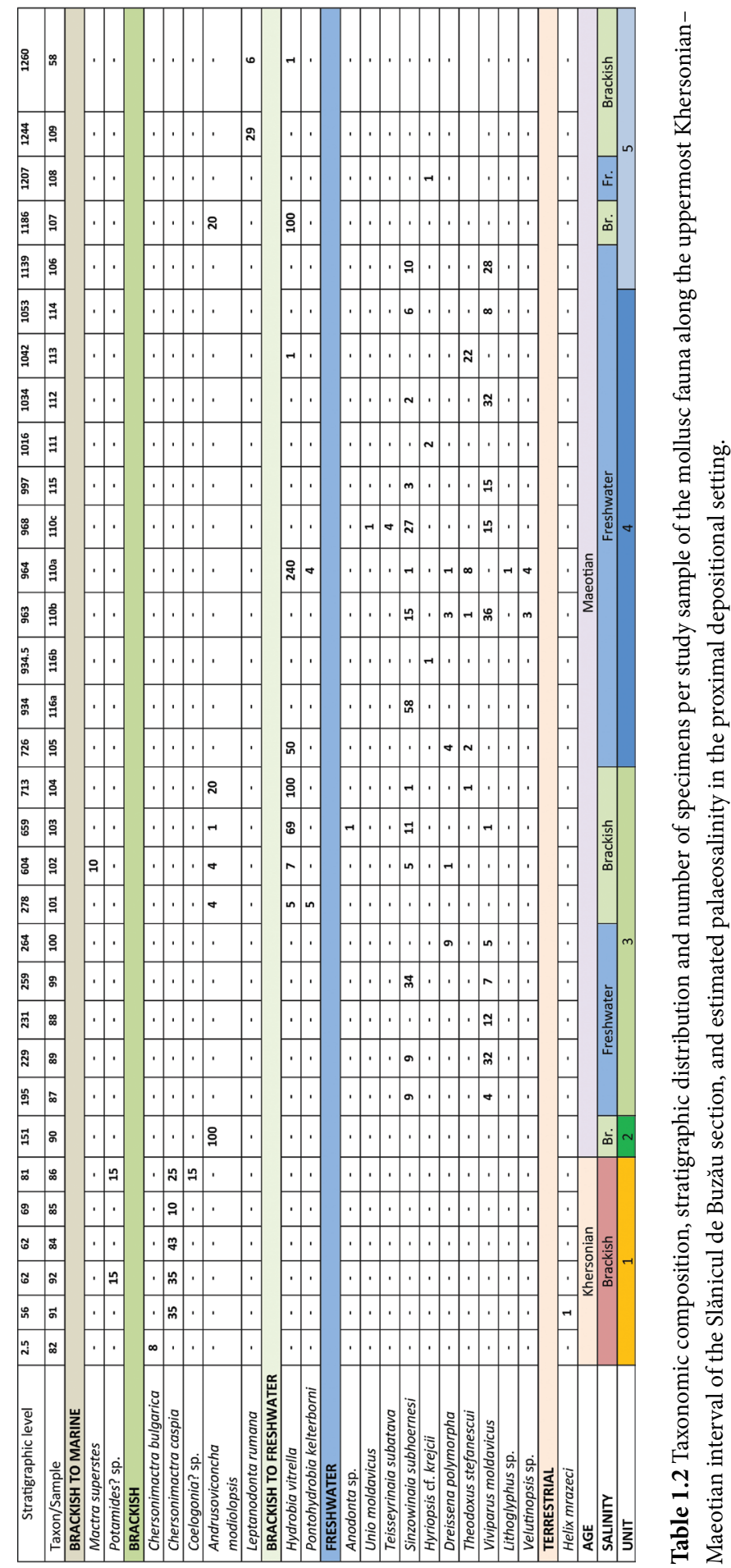




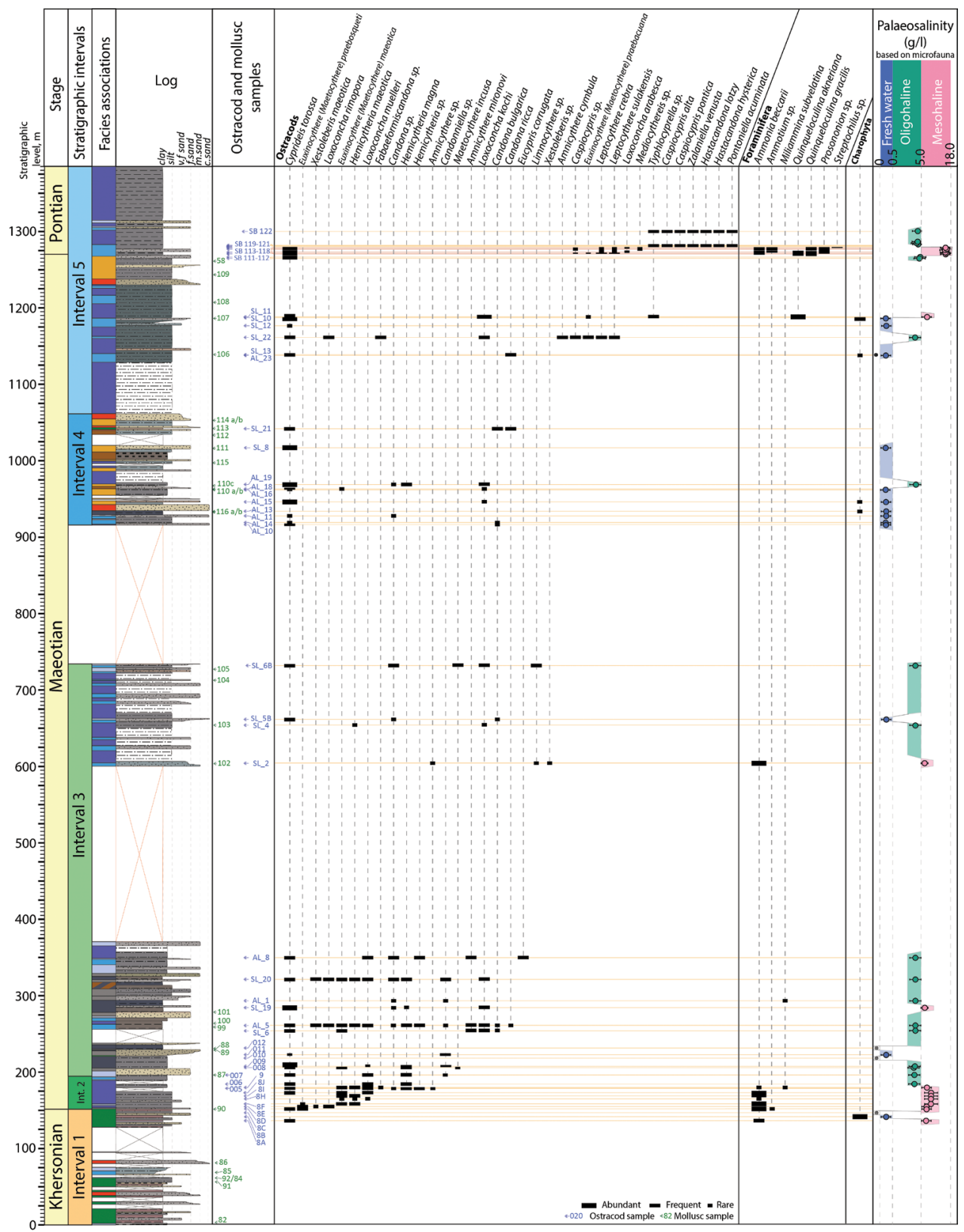

Figure 1.6 Distribution of microfauna and estimated palaeosalinity in the distal setting of the Slănicul de Buzău section. The colour meaning in the facies association column is shown in the legend of Figure 1.4. 


\section{CHAPTER 1}

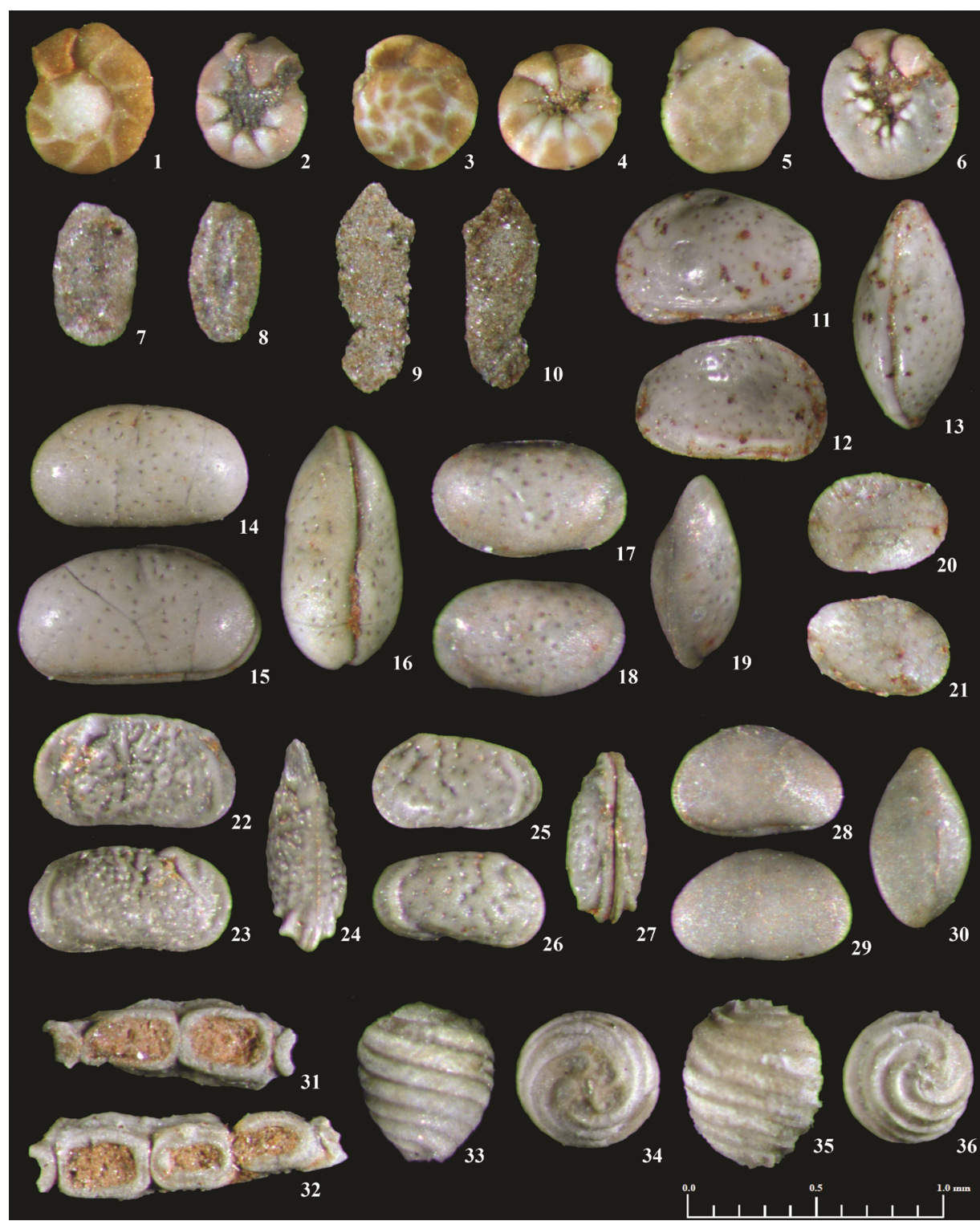

Figure 1.7 Microfossil asemblage from Unit 1 and Unit 2 (Khersonian / Maeotian transition): 1-6.

Ammonia beccarii (Linné); 7, 8. Miliammina subvelatina Venglinskij; 9, 10. Ammotium sp.; 11-13.

Hemicytheria maeotica Olteanu; 14-16. Cyprideis torosa (Jones), smooth specimens; 17-19. Loxoconcha rimopora Suzin; 20,21. Loxoconcha mulleri (Méhes); 22-24. Euxinocythere (Maetocythere) praebosqueti

Suzin; 25-27. Euxinocythere (Maetocythere) maeotica (Livental); 28-30. Xestoleberis maeotica Suzin; 31, 32. Tamanicella lapidosa (Pallas); 33-36. Nitellopsis (Tectochara) meriani (Braun ex Unger) - charophyta algae gyrogonites. 
predominant occurrence of FA2, FA3, FA4 and FA5 and an upper part (329-734.1 m) consisting mostly of FA1 and FA2 (Fig.1.4, Table 1.1). While the lower part is exposed fairly continuously, the upper part has a large gap in exposure (370-600 m).

Stratigraphic interval 3 starts with some wave ripple-cross laminated sandstones and thinly laminated siltstones attributed to FA3 and FA2 respectively. These gradually pass into massive low-angle cross-laminated sandstones of FA4, followed by dark grey, organic-rich claystones with plant detritus attributed to FA5 (Table 1.1, Fig. 1.4). FA2 and FA3 dominate between 188 and $201 \mathrm{~m}$, followed by an interval with predominant FA4 and FA5 (201-238 m). After a short $(18 \mathrm{~m})$ gap in the section FA1, FA2 and FA3 return in the $256-273 \mathrm{~m}$ interval, while FA4 and FA5 govern the subsequent 273-329 m interval. The contact between FA4 and FA5 is usually sharp, and the sandstone surface is covered with ooids and broken shell fragments. At $220 \mathrm{~m}$, FA5 is succeeded by a remarkable $1 \mathrm{~m}$-thick coal layer attributed to FA9.

The upper part of SI3 $(329-734.1 \mathrm{~m})$ is mainly composed of claystones with rare bioturbated, convolute and wave-ripple cross-laminated sandstone packages (FA1, FA2 and FA3, Table 1.1). Several isolated sandstone bodies within FA1 (marked $\mathrm{T}^{\star}$ ) have a sharp base, horizontal lamination followed by convolute bedding and climbing as well as current ripples on their top surface.

The mollusc fauna in SI3 was mainly found in the sandstone packages of FA3 and FA4. In the interval 195.5-264.2 m, a typical freshwater fauna with Viviparus moldavicus, Sinzowinaia subhoernesi and Dreissena polymorpha occurs (Fig. 1.5, Table 1.2). The overlying interval (278.3-726.9 m) contains Mactra superstes, brackish water hydrobiids - Pontohydrobia kelterborni and Hydrobia vitrella, as well as a few dreissenids, unionids, and viviparids (Fig. 1.5, Table 1.2).

The microfauna of SI3 comprises a low brackish ostracod assemblage with some freshwater species (Fig. 1.6). The most common brackish water ostracod species are Euxinocythere (Maetocythere) maeotica, Amnicythere mironovi, Amnicythere sp., Hemicytheria maeotica, Hemicytheria magna, Loxoconcha muelleri, Loxoconcha kochi, L. rimopora, Limnocythere sp., Xestoleberis maeotica, Eucypris corrugate, and euryhaline genus Cyprideis torosa (Fig. 1.8). Freshwater ostracods are represented by candoniid species like Candona ricca, Candona bulgarica and Candoniella sp. (juveniles of Candona sp.) (Fig. 1.9).

\subsubsection{Stratigraphic interval 4 - upper Maeotian}

Stratigraphic interval 4 (915.7-1061.4 m) is separated from SI3 by a $182 \mathrm{~m}$ gap in exposure (Fig. 1.4). SI4 begins with claystones of FA1 and FA2 that upwards gradually develop into hummocky cross-stratified sandstone (FA2), wave-ripple and low-angle cross-laminated sandstones (FA3-FA4) and bioturbated massive to fissile mudstones (FA5) (915.7-934.8,m, Fig. 1.4, Table 1.1). There subsequently is a distinctive, thick $(<8 \mathrm{~m})$ sandstone bed with a sharp, undulating base (FA8A, 934.8-942.8 m, Fig. 1.4, Table 1.1). Above this bed, there are repetitive 


\section{CHAPTER 1}

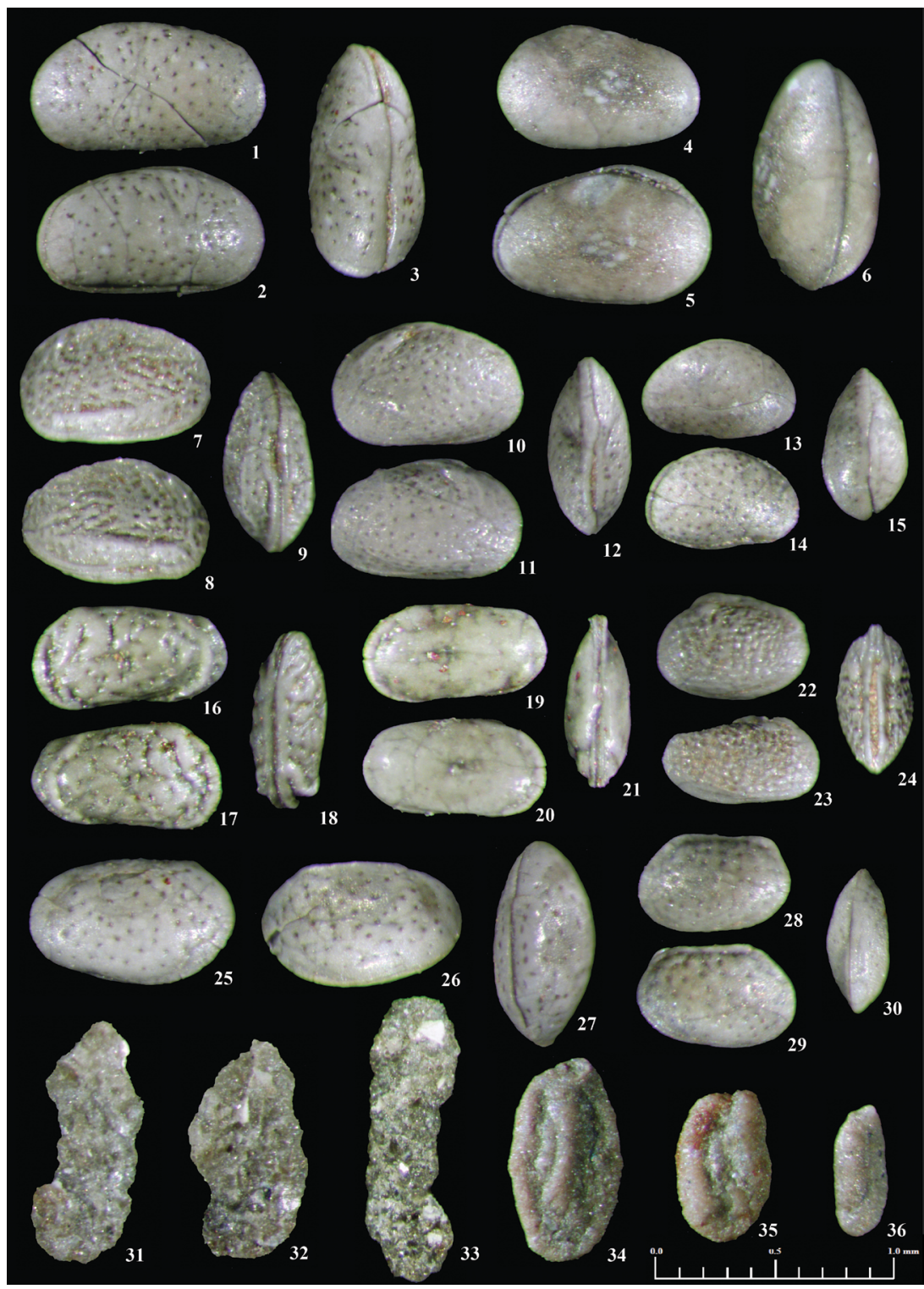

Figure 1.8 Brackish ostracods and foraminifera from Unit 3 and Unit 4 (Maeotian): 1-3. Cyprideis torosa (Jones), smooth specimens; 4-6. Eucypris corrugata Stancheva; 7-9. Hemicytheria magna Olteanu; 10-12. Hemicytheria maeotica Olteanu; 13-15. Xestoleberis meotica Suzin; 16-18. Euxinocythere (Maetocythere) maeotica (Livental); 19-21. Amnicythere mironovi (Schneider); 22-24. Loxoconcha kochi Méhes; 25-27. Loxoconcha rimopora Suzin; 28-30. Loxoconcha mulleri (Méhes); 31-33. Ammotium sp.; 34-36. Miliammina subvelatina Venglinskij. 


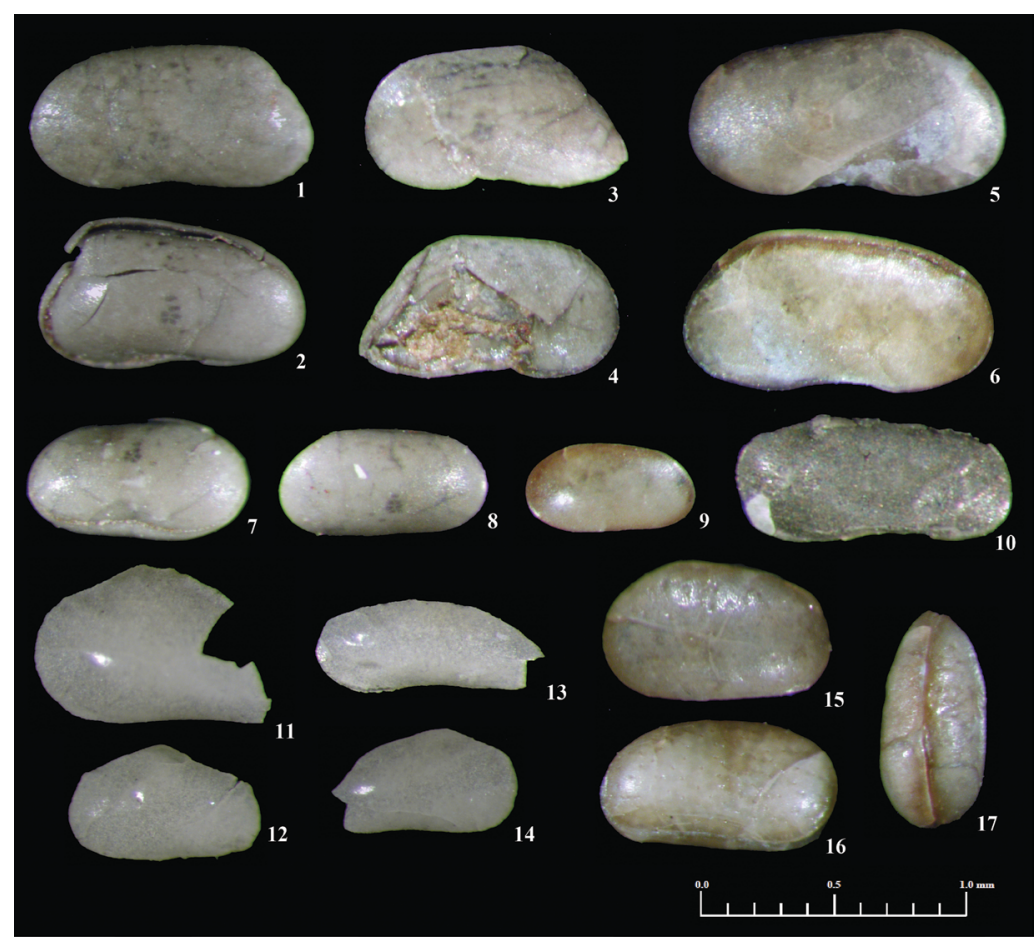

Figure 1.9 Freshwater ostracods from Unit 3 and Unit 4 (Maeotian): 1, 2. Candona ricca Stancheva; 3, 4. Candona bulgarica Stancheva; 5, 6. Candona sp.; 7-9. Candona sp. juveniles, frequent named as Candoniella sp.; 10. Fabaeformiscandona sp. (internal pyriteised cast); 11, 12. Eucypris sp. (fragmented valves); 13, 14. Typhlocyprella sp. (fragmented valves); 15-17. Cyprideis torosa (Jones).

successions that start either with grey thinly parallel-laminated claystones (FA1) or with brown fissile mudstones (FA6), followed by thickening upwards current-ripple and trough crosslaminated sandstones (FA7). In the upper part of SI4, this succession is repeatedly finished with a massive planar cross-bedded sandstone of FA8, the final one of which is thick, with erosive base ( $\sim 6 \mathrm{~m}$ ) (Fig. 1.3F, 1.3G, Table 1.1). In the 1041-1043 $\mathrm{m}$ interval, there is furthermore a notable mudstone with a mottled aggregate structure (FA9, Fig. 1.4, Table 1.1), interbedded with thin sandstones.

The mollusc fauna observed within SI4 is mostly situated between the thin current-ripple cross-laminated sandstone beds of FA7, and represented by a rich freshwater association with Dreissena polymorpha, Sinzowinaia subhoernesi, Unio moldavicus, Teisseyrinaia subatava, Hyriopsis cf. krejcii, Theodoxus stefanescui, Viviparus moldavicus, Lithoglyphus sp., Velutinopsis sp. (Table 1.2, Fig. 1.5). At $964.3 \mathrm{~m}$, a remarkably high number of Hydrobia vitrella was found in the grey siltstones. 
The micropalaeontological association of SI4 is dominated by freshwater ostracods but also contains a few brackish water species. Characteristic for this interval is the abundance of the euryhaline species Cyprideis torosa, frequently with shells filled with secondary calcite (Fig. 1.8) The candoniid ostracods are represented by Candona sp. (mostly in juvenile stages recorded as Candoniella sp.), rare Candona ricca, Candona bulgarica, and Eucythere corrugata (Fig. 1.9). The only interval with brackish ostracods (969.9 m) contains a few specimens of Hemicytheria magna, Loxoconcha muelleri, L. kochi, Limnocythere sp. (Fig. 1.6).

\subsubsection{Stratigraphic interval 5 - Maeotian-Pontian transition}

Stratigraphic interval 5 (1061.4-1380 m, Fig. 1.4) mainly consists of bluish-grey fissile, horizontally planar-laminated claystones (FA1) that abruptly cover the final distinct FA8 sandstone of SI4 (Fig. 1.4, Table 1.1). Locally, among the claystones, 0.2-1 m-thick sandstone packages with various sedimentary structures occur, which can be classified into two types. The first type has a gradual base and shows planar-cross and low-angle cross lamination and is thus attributed to FA2 (Fig. 1.4, Table 1.1). The second type is sharp-based and displays low-angle or parallel lamination at the base, climbing ripples and convoluted bedding in their middle part and current or wave ripples in their upper part (1175-1187 m, Fig. 1.4). These sandstones, marked as $\mathrm{T}^{\star}$ on Figure 1.4, were noted before in SI3 and are characteristic for FA1 (Table 1.1).

At $1230 \mathrm{~m}$, massive sharp-based thickly-bedded planar cross-laminated FA8B-type sandstone with plant detritus and mud drapes disrupts the claystone record (Fig. 1.4). Above the FA8B sandstone, there are frequent sharp-based trough-cross laminated FA7 sandstones $(1237.7-1267 \mathrm{~m})$. The siltstones directly underlying these beds demonstrate soft-sediment deformation structures. In interval 1267-1282 $\mathrm{m}$, the sandstones show either parallellamination or rarely wave ripple cross-lamination and hence were assigned to FA2 (Table 1.1). Further up, the section shows mainly parallel-laminated claystone (FA1) with some rare sandstone beds (FA2, FA3, Fig. 1.3).

The mollusc fauna of Interval 5 mainly occurs in sandstone beds. Between 1139 and 1186.8 $\mathrm{m}$, there is a freshwater assemblage with Sinzowinaia subhoernesi and Viviparus moldavicus (Fig. 1.5). Starting from $1186.8 \mathrm{~m}$, the mollusc fauna contains brackish water assemblages with Andrusoviconcha modiolopsis, Hydrobia vitrella and Leptanodonta rumana (Fig. 1.5, Table 1.2). From $1265 \mathrm{~m}$, remarkable thin $(5-15 \mathrm{~cm})$ shell beds with brackish water Coelogonia novorossica occur (Fig. 1.10). These beds continue in the record until $1286 \mathrm{~m}$ where the first Eupatorina littoralis occurs.

The microfauna of SI5, like the mollusc fauna, demonstrates a change from freshwater to brackish water assemblages. In interval 1139-1166 m, a freshwater microfauna assemblage with Candona ricca, Cyprideis torosa and gyrogonites of Nitellopsis sp. is present (Fig. 1.6). At $1166 \mathrm{~m}$, brackish water assemblage with Cyprideis torosa, Leptocythere crebra, L. sulakensis, Euxinocythere praebacuana, Amnicythere cymbula, Loxoconcha kochi, L. muelleri occurs 


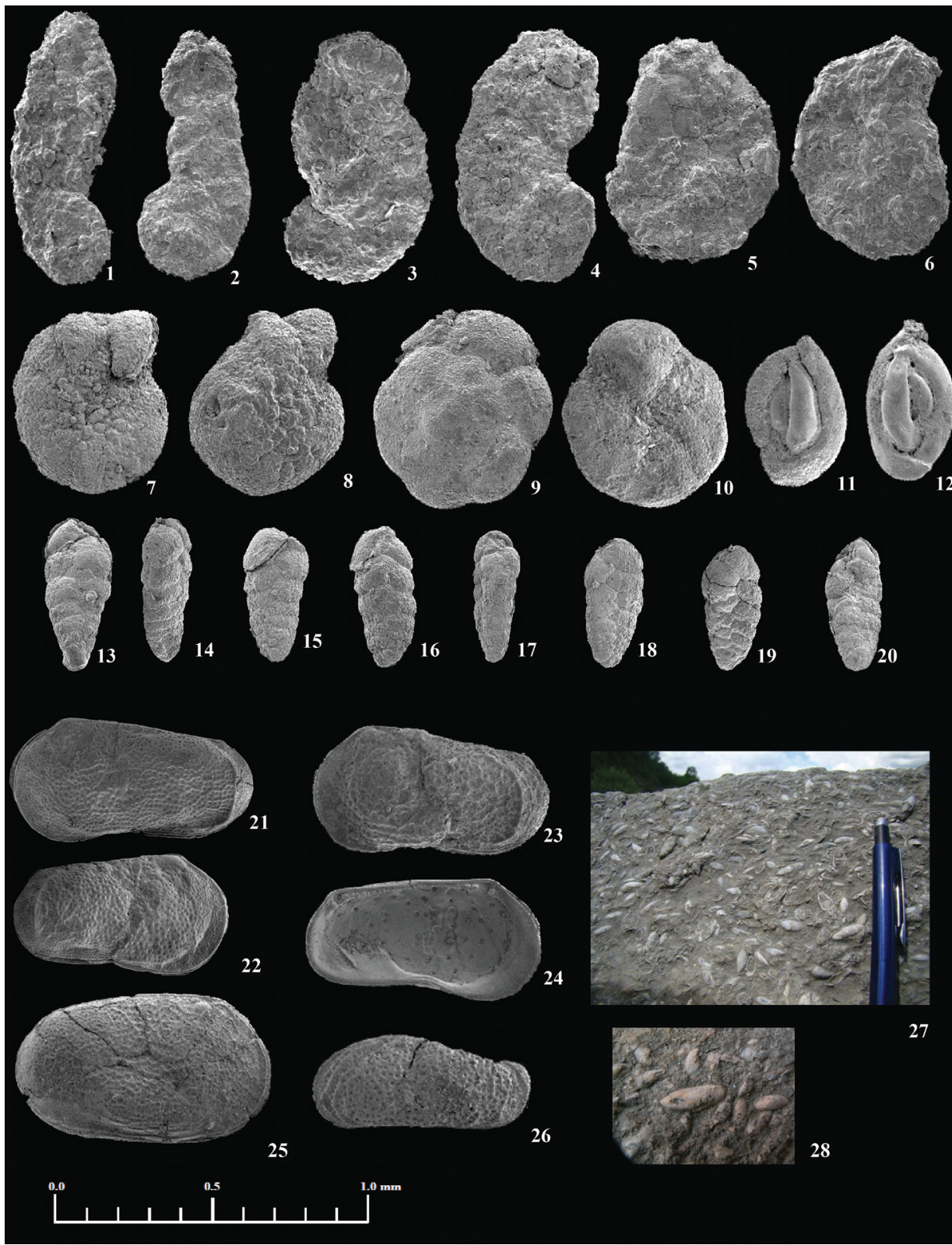

Figure 1.10. Foraminifera, ostracods and bivalves from Upper Maeotian-Pontian boundary (Flooding interval) 1-6. Ammotium sp., different morphotypes; 7, 8. Porosononion sp. 9,10. Ammonia ex.gr. beccarii (Linné); 11,12. Quinqueloculina aff. gracilis Karer; 13-20. Streptochilus sp. (bad preserved specimens); 21, 22. Leptocythere aff. sulakensis Suzin; 23, 24. Leptocythere aff. crebra Suzin; 25. Loxoconcha arabesca Olteanu; 26. Mediocytheries sp.; 27, 28. Shell accumulation with Coelogonia novorossica (Andrusov). 
(Fig. 1.6, 1.10). At $1186.8 \mathrm{~m}$, we discovered an assemblage dominated by the foraminifera Quinqueloculina sp. and the fragile (mainly fragmented) ostracod Typhlocyprella sp. (Fig. 1.6).

From 1265 m, high-resolution micropalaeontological sampling was performed (Fig. 1.11). In the interval 1265-1270 m (SB111-SB112) a low brackish water monospecific assemblage

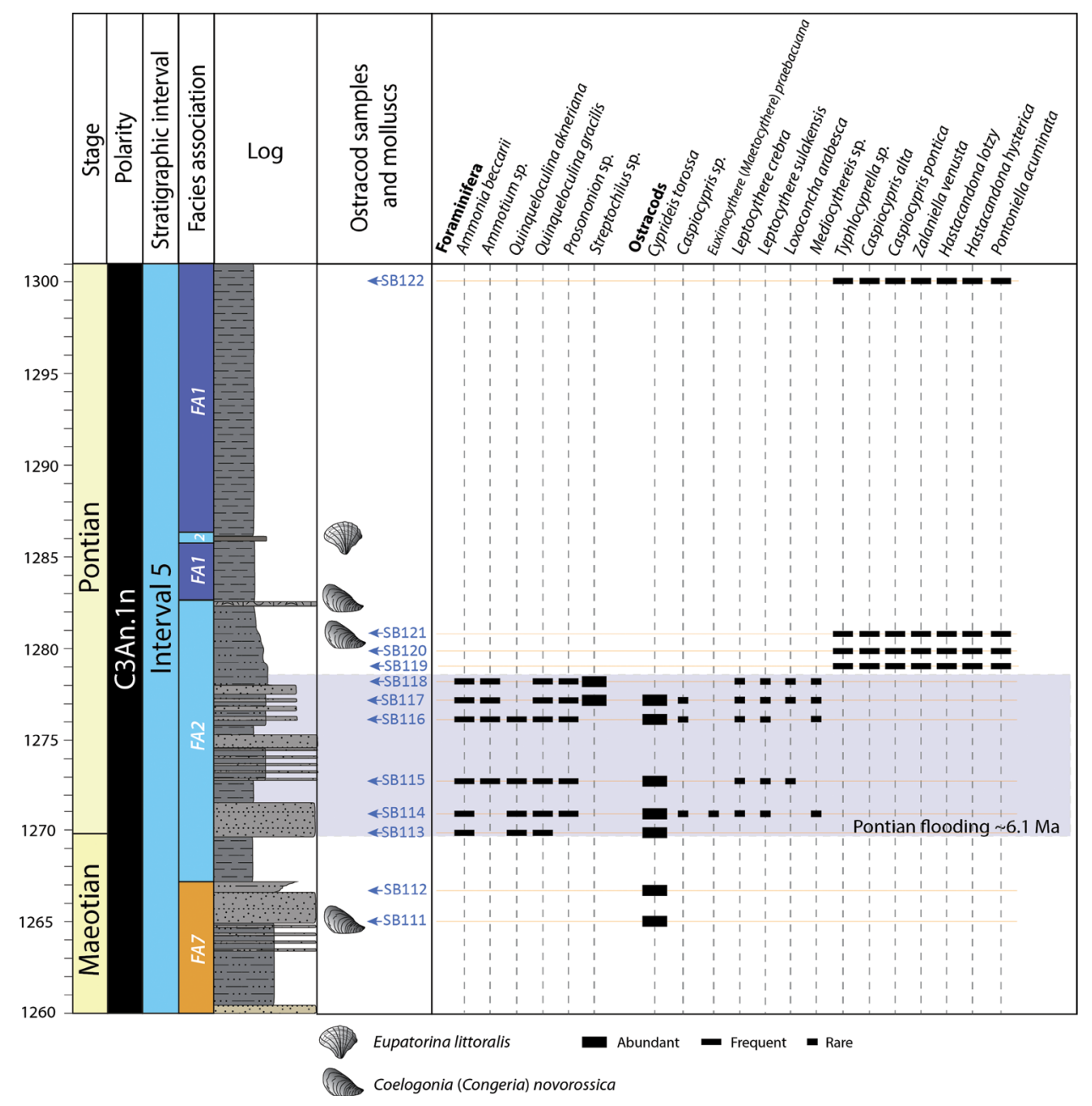

Figure 1.11 Magneto-biostratigraphic characteristic of the Maeotian-Pontian boundary in the Slănicul de Buzău section. The colour meaning in the facies association column is shown in the legend of Figure 1.4.

with Cyprideis torosa was discovered. Between 1270-1278 m (SB113-SB118) a very different meso- to polyhaline microfauna is present, characterised by abundant foraminifera Ammonia beccarii, Ammotium sp., Quinqueloculina akneriana, Q. gracilis, Prosononion sp. and Streptochilus sp. and ostracods Caspiocypris sp., Euxinocythere (Maetocythere) praebacuana, 
Leptocythere crebra, L. sulakensis, Loxoconcha arabesca and Mediocythereis sp. (Fig. 1.10, 1.11). The following interval 1279-1300 m (SB119-SB122) contains no foraminifera, but a low brackish water ostracod assemblage with Caspiocypris alta, C. pontica, Zalaniella venusta, Hastacandona lotzy, H. hysterica, Pontoniella acuminata and Typhlocyprella sp. (Fig. 1.8, 1.10, $1.11)$.

\subsubsection{Magnetostratigraphy}

Demagnetization of 157 samples with alternating field and/or thermal methods typically revealed two magnetic components. The first magnetic component is demagnetised between $180^{\circ} \mathrm{C}-210^{\circ} \mathrm{C}$ for thermal measurements $(\mathrm{TH})$ and between $20-25 \mathrm{mT}$ for measurements in alternating field (AF) (Fig. 1.12A, 1.12B). The combined mean direction of the first component for both $\mathrm{AF}$ and $\mathrm{TH}$ measurements, has parameters of $\mathrm{D}=358.5^{\circ}, \mathrm{I}=66.1^{\circ}, \mathrm{k}=20.3, \alpha 95=3.9$ for $\mathrm{N}=67$ samples in geographic coordinates (Fig. 1.12C) For the Slănicul de Buzău area, the expected direction of the geocentric axial dipole (GAD) field is $\mathrm{I}=62.85^{\circ}$ (https://www.ngdc. noaa.gov, June 2016), which is close to the measured inclination of the first component. We, therefore, interpret the first component to represent the present-day magnetic field overprint.

The second magnetic component most commonly demagnetizes in a range $400^{\circ} \mathrm{C}-440^{\circ} \mathrm{C}$ $(\mathrm{TH})$ or $60-80 \mathrm{mT}(\mathrm{AF})$ (Fig. 1.12D, 1.12E). The thermomagnetic runs show a decrease of magnetization up to $420^{\circ} \mathrm{C}-440^{\circ} \mathrm{C}$ and subsequently form a peak that drops off at $580^{\circ} \mathrm{C}$ (Fig. 1.12F, 1.12G). Such behaviour and the curve shape are typical for the oxidation of pyrite followed by magnetite demagnetisation. The combined mean direction for all normal samples demagnetised thermally and in alternating field has parameters of $\mathrm{D}=354^{\circ}, \mathrm{I}=54.6^{\circ}, \mathrm{k}=15.4$, a95 $=5.0$ for $\mathrm{N}=56$ in tectonic coordinates, while for all reversed directions combined the parameters are $\mathrm{D}=167.6^{\circ}, \mathrm{I}=-54.7^{\circ}, \mathrm{k}=17.1$, a95 $=4.8$ for $\mathrm{N}=55$, equally in tectonic coordinates (Fig. 1.12H). Both the classical (McFadden and McElhinny, 1990) and the bootstrap (Tauxe, 2010) reversal tests are positive for the second magnetic component. Therefore, the second magnetic component is interpreted as being characteristic for the depositional age characteristic remanent magnetisation (ChRM).

The two antipodal NRM directions have been detected in some rare samples from SI5 (Fig. 1.12I). The first of these two directions demagnetises at $270^{\circ} \mathrm{C}-290^{\circ} \mathrm{C}$, while the second one demagnetizes at $360^{\circ} \mathrm{C}->400^{\circ} \mathrm{C}$. These demagnetization temperature ranges are characteristic for greigite. Antipodal directions are known from the Dacian Basin and linked to two different greigite generations: the low-temperature authigenic and the high-temperature magnetosomal (Vasiliev et al., 2008; Kelder et al., 2018). The low-temperature diagenetic greigite formed later than the magnetosomes and thus acquired a later magnetic field (Vasiliev et al., 2008). For the determination of a true magnetic signal, we used the second, high-temperature greigite directions, whose polarity is in accordance with the other samples below and above, which only have a ChRM component. 


\section{CHAPTER 1}

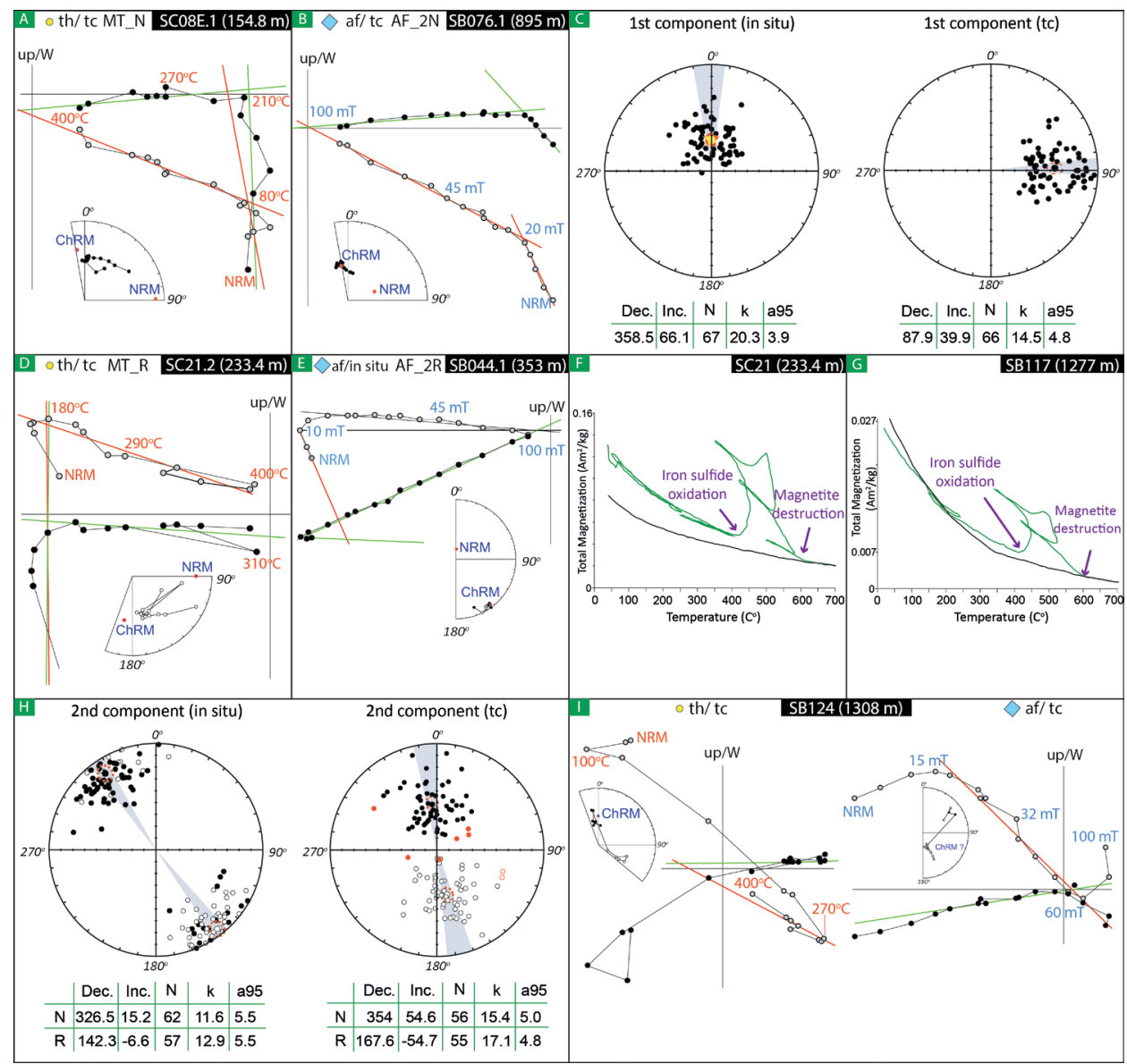

Figure 1.12. Zijderveld diagrams, equal area plots and thermomagnetic curves for samples from the Slănicul de Buzău section. Zijderveld diagrams with representative 1st magnetic component for: A. thermally demagnetised samples $\left(0-210^{\circ} \mathrm{C}\right)$; B. demagnetised in alternating field samples $(0-20 \mathrm{mT})$; representative 2 nd magnetic component for: $\mathrm{D}$. thermally demagnetised samples $\left(180-400^{\circ} \mathrm{C}\right)$; $\mathrm{E}$. demagnetised in alternating field $(20-100 \mathrm{mT})$. Equal are plots of the: $\mathrm{C}$. 1st magnetic component in geographic (in situ) and in tectonic (tc) coordinates; $\mathrm{H}$. all normal and reversed ChRM direction (2nd magnetic component) in geographic (in situ) and tectonic ( $\mathrm{tc}$ ) coordinates. The yellow star represents the current day GAD direction of the studied area. Thermomagnetic runs showing different magnetic carriers: F and G. Pyrite and magnetite; I. Zijderveld diagrams showing the antipodal direction in the sample with two generations of greigite: diagenetic $\left(100-270^{\circ} \mathrm{C}\right.$ or $\left.20-60 \mathrm{mT}\right)$ and characteristic $\left(270-400^{\circ} \mathrm{C}\right.$ or 60-100 mT). Abbreviations and parameters: th - thermally demagnetised; af - demagnetised in alternating field; tc - tectonically corrected coordinates; in situ - geographic coordinates; NRM - natural remanent magnetization; ChRM - characteristic remanent magnetization; Dec. - declination; Inc. - inclination; 
$\mathrm{N}$ - number of samples; $\mathrm{k}$ - precision parameter of Fischer, a95 - 95\% cone of confidence; MT_N and MT_R - medium temperature component with normal and reversed direction correspondingly; AF_2N AF_2R - alternating field demagnetised component with normal and reversed direction correspondingly.

The magnetostratigraphic record of the studied interval in Slănicul de Buzău consists of three normal zones and four major reversed zones, two of which are interrupted by some unexposed intervals (Fig. 1.13). The section starts with reversed zone R1a that is followed by a gap between $95.8-127.6 \mathrm{~m}$. After the gap, the upper part of SI1 begins with reversed polarity of zone R1b (127.6-138.3 m) and after that the normal zone N1 covers the rest of SI1, SI2 and lower part of SI3 (139.3-228.2 m). Within the normal zone, a short reversed level (345.5-348.5 $\mathrm{m}$ ) has been detected that we interpret as an anomaly. Between normal zones N1 and N2 the magnetostratigraphic record is represented by the long R2 reversed zone that consists of R2a (228.2-386 m), R2b (516 m), R2c (596-728 m) separated by three major gaps (Fig. 1.13). Upwards from normal zone N2 (890?-952.5/974 m), which has an ill-defined lower limit, the section is fairly continuous. In the middle part of SI4 the reversed zone R3 (952.5/974) $\mathrm{m}$ $1085 \mathrm{~m})$ occurs and is succeeded by a long normal zone N1 (1085-1362 m) that switches to reverse R4 at $1362 \mathrm{~m}$ (Fig. 1.13).

\subsubsection{Palaeoenvironmental interpretation}

The interpretation of depositional environments is based on an analysis of sedimentary facies (Table 1.1) and supported by the associated microfauna and molluscs. Salinity trends are based on ostracod and mollusc assemblages. The frequent occurrence of chaotically distributed mollusc fauna in sandy layers suggests that they were transported downslope from a shallower setting. Analysis of these mollusc assemblages provides an estimation of salinity in the marginal, shallow water parts of the basin. The ostracod fauna present in offshore relatively deep-water mud deposits is considered as a representative indicator of salinity in the distal parts of the basin. For our estimation of salinity, we use the Venice system with freshwater $(0-0.5 \mathrm{~g} / \mathrm{l})$, oligohaline (0.5-5 g/l) mesohaline (5-18 g/l) and polyhaline (18-30 g/l) ranges (The Venice System for the Classification of Marine Waters According to Salinity, 1958).

\subsubsection{Stratigraphic interval 1 - upper Khersonian}

We interpret the lower and upper parts of SI1 with the sandstone - grey mudstone - red claystone packages as being deposited in coastal lagoons and floodplains (FA9) that were subject to small periodic transgressions (Table 1.1). The red palaeosols with scarce freshwater oogonides were formed on floodplains. The sandstone packages with wave ripples and planar cross-lamination represent coastal barriers and crevasse splays respectively. The limestones with Chersonimactra shells (lower part of SI1) and the massive mudstones with abundant Ammonia 

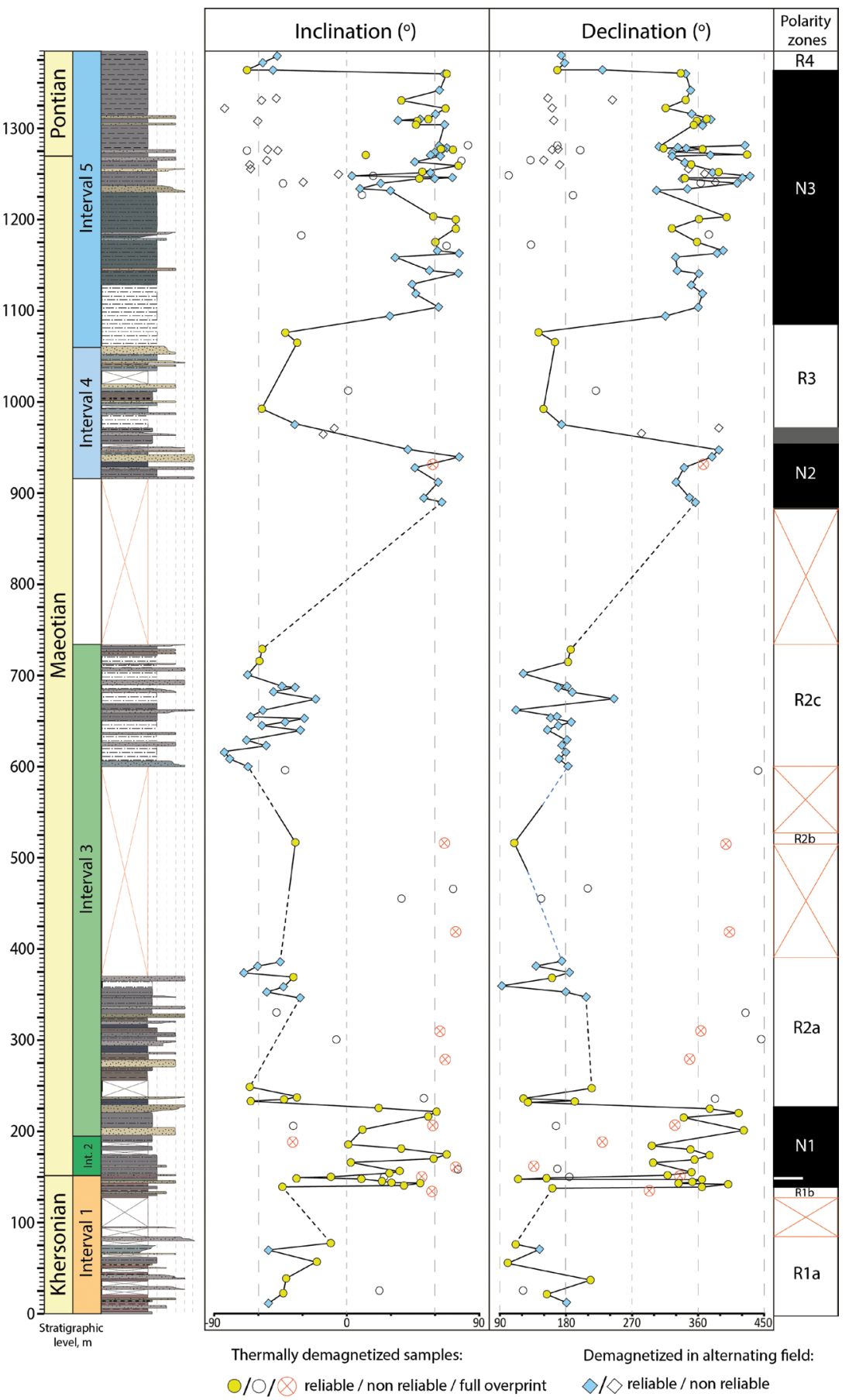

Figure 1.13. Magnetic polarity pattern identified in the Slănicul de Buzău section. 
beccarii foraminifera (upper part of SI1) reflect periods when the coastal plain was flooded by the adjacent basin.

The middle part of SI1 was formed in littoral environments ranging from offshore to shoreface (FA1-FA3, Table 1.1). The parallel-laminated coarsening upwards siltstones accumulated in a quiet offshore setting with a lack of bioturbation probably due to weak oxygenation. The upper beds of these packages with wave-ripples and low-angle crosslamination characterize deposition on a shoreface with a marked wave activity (FA3, Table 1.1). The highly erosive fining upward sandstone body $(81-84 \mathrm{~m}$ ) with intraformational breccia at the base is interpreted as a channel with diminishing activity towards the top (FA8A, Table 1.1).

The mollusc fauna found within the lower and middle parts of SI1 is indicative for the Khersonian (sub)stage of the Eastern Paratethys (Paramonova 1994). The occurrence of the euryhaline genus Chersonimactra together with Coelogonia? sp. and Potamides? sp., suggest an oligo- to mesohaline salinity for the coastal lagoons and nearshore (shoreface) part of the basin (Table 1.2). Helix mrazeci is terrestrial and its co-occurrence with Sarmatimactra bulgarica at 56 $\mathrm{m}$ points at proximity of shallow marine and terrestrial depositional environments.

The upper part of SI1 lacks mollusc fauna but displays an alternation of intervals with brackish water foraminifera, freshwater oogonides and small barren intervals. The association of Ammonia beccarii and euryhaline Cyprideis torosa, which occur in lagoon mudstones, indicates a lower mesohaline salinity (5-7 g/l.) We thus interpret the upper Khersonian (SI1) to have been deposited in coastal lagoon and floodplain environments, shortly interrupted by littoral conditions.

\subsubsection{Stratigraphic interval 2 - Khersonian - Maeotian transition}

At the onset of SI2, there is a major transition from coastal plain (FA9) to offshore (FA1) depositional settings. The gradual transition from yellow siltstone (FA9) into low-angle crossstratified sandstone (FA4) at the base of SI2 $(150.8-153 \mathrm{~m})$ indicates retreat of the coastal barrier landwards, thus covering previously deposited lagoon sediments due to a rise of relative base-level (Table 1.1) (McCubbin, 1982). The overlaying thinly parallel laminated siltstones, characteristic for most of SI2, were deposited in a low-energy environment beyond the stormwave base and with a low biological activity, which we interpret as offshore (FA1, Table 1.1). The sharp contact between the barrier sandstone and overlying offshore siltstones indicates a drowning of the back barrier-lagoon system (McCubbin, 1982). The second sandstone package with ooids (FA3, 155.7-157.7 m, Fig. 1.1) suggests a temporary return to shoreface environments with a constant agitation by wave processes and high saturation of water with calcium carbonate (Flügel, 2010).

The presence of Andrusoviconcha modiolopsis in the shoreface deposits at $151.5 \mathrm{~m}$ suggests a mesohaline salinity for the marginal parts of the basin. The almost exclusive presence of euryhaline foraminifera Ammonia in the offshore deposits, with no other calcareous 
foraminifera, implies a mesohaline salinity - below $10 \mathrm{~g} / \mathrm{l}$. The agglutinated foraminifera of genera Miliammina and Ammotium can also tolerate very low salinity.

\subsubsection{Stratigraphic interval 3 - lower Maeotian}

The wave-ripple cross-laminated sandstone $(188 \mathrm{~m})$ at the base of SI3 indicates a shoreface setting (FA3) that passes upwards into a barrier sandstone (201-204.8 m, FA4, Table 1.1). The occurrence of ooids and broken shells on the barrier top surfaces indicate a weak wave activity on the internal side of the barriers and water highly saturated in calcium carbonate (Flügel, 2010). The following dark grey claystones with plant detritus represent lagoons that were trapped by barrier islands and preserved the organic matter. The distinctive shallowing trend (FA3 - FA4 - FA5) reaches its maximum at $220 \mathrm{~m}$ where a $1 \mathrm{~m}$-thick coal layer attributed to FA9 indicates a swampy, subaerially exposed environment. Subsequently, lagoon and barrier deposits alternate up to $238 \mathrm{~m}$. Following a short $(18 \mathrm{~m})$ gap in the section, there is a return to offshore-transition and offshore deposits (FA2 and FA1) in the 251-271 m interval, after which the barrier-lagoon system returns, persisting up to $329 \mathrm{~m}$. Within this FA4-FA5 package there is a distinctive thick sandstone barrier (294-300 m, Fig. 1.3C) that covers lagoon deposits with a sharp basal surface dotted with Diplocraterion burrows (Fig. 1.3E).

The lower back-barrier-lagoon (FA4-FA5) succession and the following short offshoreshoreface interval $(195-271 \mathrm{~m})$ contain a typical freshwater mollusc assemblage with Viviparus moldavicus, Sinzowinaia subhoernesi and Dreissena polymorpha (Fig. 1.5, Table 1.2) and freshwater to low brackish water ostracod assemblage with Cyprideis torosa, Candoniella sp., Candona neglecta (Fig. 1.6). The mollusc fauna in the second FA4-FA5 succession (271$329 \mathrm{~m}$ ) contains low brackish water molluscs Andrusoviconcha modiolopsis, Hydrobia vitrella, Pontohydrobia kelterborni (278 m, Table 1.2) and numerous brackish water ostracod species (Fig. 1.6). Thereby, the lower Maeotian back-barrier-lagoon system developed in freshwater to oligohaline (up to $5 \%$ ) environments.

Following an interval with FA3 interpreted as shoreface deposits and FA2 facies interpreted as offshore transition zone (329-348 m), the whole upper part of SI3 (348-734 m) is dominated by FA1 facies interpreted as representative of the offshore (Fig. 1.4, Table 1.1). The isolated sandstone packages in this interval that are marked as $\mathrm{T}^{\star}$ on Fig. 1.4 are interpreted as turbidites because their internal structure follows the classic Bouma sequence (Bouma 1963). On the contrary, the gradually thickening bioturbated sandstone packages with low-angle crosslamination and locally wave-ripple marks (e.g. 655.5-661 m, Fig. 1.4) are interpreted to have formed under the influence of storms and wave activity, suggesting an offshore transition (FA2) or shoreface (FA3) origin.

The mollusc fauna from this upper part of SI3 contains brackish water assemblages with minor freshwater elements: Mactra superstes, Andrusoviconcha modiolopsis, Hydrobia vitrella, Sinzowinaia subhoernesi, etc. (Table 1.2). The microfauna from the upper part of SI3 is 
represented by oligohaline species with, however, a taxonomic and quantitative decrease (Fig. 1.6).

\subsubsection{Stratigraphic interval 4 - upper Maeotian}

The base of SI4 (915.7-942.8 m, Fig. 1.4) consists of a shallowing-upwards succession from offshore (FA1) to shoreface (FA3) and back-barrier-lagoon (FA4-FA5), followed by the arrival of a large distributary channel (FA8, Fig. 1.4). The thin-parallel laminated claystones (FA1) suggest accumulation in a quiet offshore setting below the storm wave base. The following thickly-bedded hummocky cross-stratified sandstone reveals storm wave activity within the offshore transition zone (FA2). The overlying wave-rippled sandstone points at active wave generated motions and thus suggests accumulation on the shoreface (FA3). The succeeding low-angle cross-bedded sandstones with structureless organic-rich mudstones are interpreted as a back barrier-lagoon system (FA4-FA5) with a distributary channel on top (FA8) (Table 1.1). Interpretation of the latter is supported by its erosive base as well as a well-developed intraformational mud clast breccia suggesting erosion (collapse) of the upstream mud-ground. It also contains a transition from planar cross-lamination through trough-cross lamination to current ripples, characteristic for the diminishing energy of deposition in a laterally migrating distributary channel.

The overlying 945-1061 m interval shows 7 repetitions of a typical shallowing upwards succession (e.g. Fig. 1.3F). These successions start either with grey thinly parallel-laminated claystones (FA1) or with brown fissile mudstones (FA6) interpreted to have deposited from suspension fallout in offshore and prodelta environments below the wave base (Table 1.1, Fig. 1.4). The overlying thickening upwards current-ripple and trough cross-laminated sandstones (FA7) are interpreted as the prograding delta front. While the lower four successions terminate on the distal delta front, the 5th succession terminates on the proximal delta front and the final two successions terminate with mouth bar (FA8B) to channel (FA8A) facies. These seven cyclic shallowing-upwards successions are interpreted as delta-front cycles (e.g. Jorissen et al., 2018), with an overarching gradual shallowing upwards trend culminating in mouth-bar (FA8B, erosively-based channel (FA8A) and red, mottled palaeosol (FA9) deposits in the final two cycles.

The mollusc fauna of SI4 consists of freshwater species like Sinzowinaia subhoernesi, Unio moldavicus, Teisseyrinaia subatava, Hyriopsis cf. krejcii, Theodoxus stefanescui, Viviparus moldavicus (Fig. 1.5, Table 1.2), which are considered typical for the upper Maeotian (Wenz, 1942; Roshka, 1973; Paramonova, 1994). In our section, this fauna is distributed in the delta front and delta top depositional setting, where the occurrence of freshwater forms is expected. The domination of Candona sp. in offshore deposits (Fig. 1.6) and a rare occurrence of brackish water molluscs and ostracods (964.3 m, Fig. 1.6 and 969.9 m, Table 1.1) suggests intense 
freshening of the basin margins and a probably very low brackish (low oligohaline) salinity of the more distal parts of the basin.

\subsubsection{Stratigraphic interval 5 - Maeotian - Pontian transition}

Stratigraphic interval 5 was interpreted to have been mainly deposited in the offshore (Fig. 1.4, Table 1.1). The fissile planar parallel claystones and siltstones (FA1) deposited in quiet environments, beyond storm and wave activity. While sandstones of the first type identified above (indicated as FA1 $\mathrm{T}^{\star}$ ) are turbidites that display a classic Bouma sequence, sandstones from the second type are the product of storms acting in the offshore transition zone (FA2). The massive planar cross-laminated sandstone at $1230 \mathrm{~m}$ does not have an erosive base and is interpreted as a mouth bar deposit (FA8B). It is overlain by thin sandstone beds deposited on the delta front (FA7, Table 1.1). The following sandstones of interval 1267-1282 m accumulated in an offshore transition setting (FA2, Table 1.1). Subsequently, the sandstones disappear and offshore depositional settings prevail until the end of the studied section.

Both molluscs and microfauna indicate fresh water in the lower part of SI4. From $1166 \mathrm{~m}$, some brackish water pulses indicated by Quinqueloculina sp. and fragile candonid ostracods (mainly fragmented) Typhlocyprella alternate with layers containing freshwater molluscs. At $1265 \mathrm{~m}$, Coelogonia novorossica and Cyprideis torosa suggest an oligohaline salinity. An abundance of foraminifera between 1270 and $1278 \mathrm{~m}$ indicates an abrupt rise of salinity to meso- polyhaline values (Fig. 1.11), which is followed by an interval with oligohaline ostracods $(1279-1300 \mathrm{~m})$.

\subsection{Discussion}

\subsubsection{Magneto-biostratigraphic correlation to GPTS}

The incompleteness of the record in the middle part excludes a straightforward correlation of the acquired polarity pattern to the GPTS (Fig. 1.14). However, the lower and upper parts where the stage boundaries are exposed can be used as important tie-points.

The Maeotian-Pontian boundary is characterised by the occurrence of new marine assemblages of ostracods, foraminifers, nannoplankton and molluscs that entered the Paratethys region from the Mediterranean and Lake Pannon (Stevanovic et al., 1989; Krijgsman et al., 2010; Popov et al., 2016; Stoica et al., 2016). This influx of marine fauna, called the "Pontian flooding", was correlated magnetostratigraphically slightly below the C3An.1n - C3r polarity switch and dated in the Dacian Basin at 6.04 Ma (Krijgsman et al., 2010). Cyclostratigraphic calibration of this boundary in the Caspian and Black seas suggest a 6.1 Ma age (Chang et al., 2014; van Baak et al., 2016; Rostovtseva and Rybkina, 2017). We place the Maeotian-Pontian boundary in Slănicul de Buzău at 1270 m (Sample SB113), in the upper part of normal zone N3, 


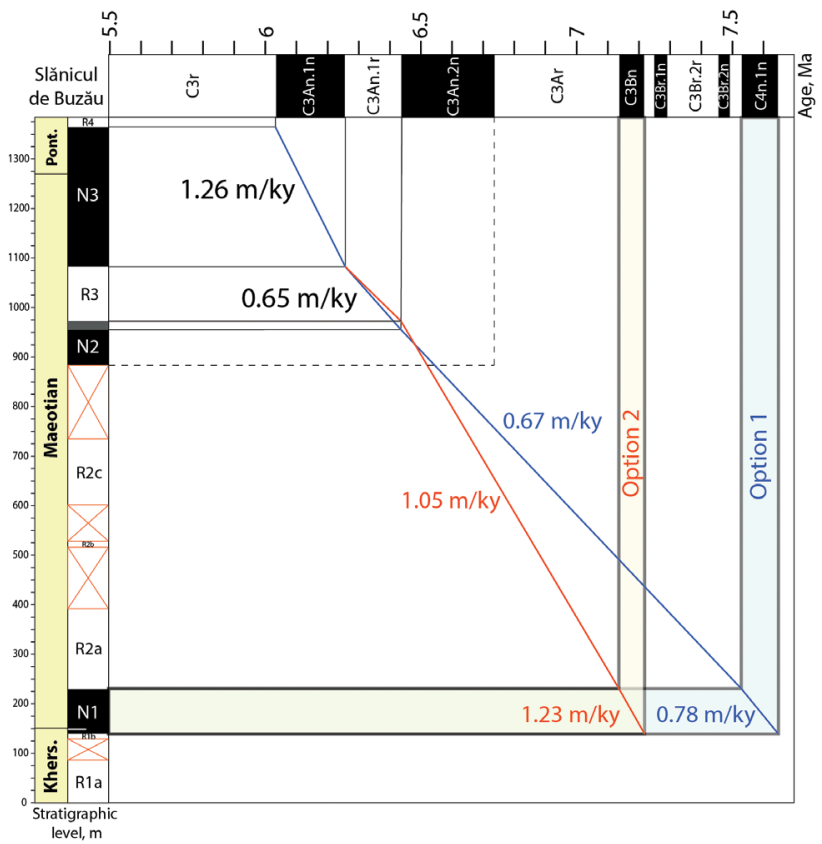

Figure 1.14. Correlation of polarity patterns to the Geomagnetic Polarity Time Scale (GPTS) and estimated sedimentation rates with two possible options.

where we note the sudden appearance of a remarkable meso-, polyhaline microfauna followed by the appearance of typical Pontian molluscs at $1286 \mathrm{~m}$ (Fig. 1.11). Considering the position of the Maeotian-Pontian boundary in the regional GTS, we correlate the normal zones N2 and N3 from the Slănicul de Buzău section to the C3An.2n and C3An.1n subchrons, respectively.

However, there is a small discrepancy with the age of $6.04 \mathrm{Ma}$ that was earlier acquired from the Rîmnicu Sărat section in the Dacian basin (Vasiliev et al., 2004; Krijgsman et al., 2010; Stoica et al., 2013; Stoica et al., 2016). In the Rîmnicu Sărat section, the polarity switch was placed at the first reversed sample, followed by a $100 \mathrm{~m}$ non-sampled, poorly exposed interval (Vasiliev et al., 2004). The high-resolution palaeomagnetic record of Slănicul de Buzău revealed a series of single reversed samples within the normal chron C3An.1n (Supplementary 1). Such behaviour, interpreted as delayed acquisition, is typical for different generations of greigite and was previously also described for chron C3r in the Bădislava section in the Dacian Basin (Vasiliev et al., 2008). The position of the C3An.1n - C3r polarity boundary in the Rîmnicu Sărat section is thus a little uncertain, which might explain the small age difference with other Eastern Paratethys sections. Our high-resolution palaeomagnetic age constraint resolves this discrepancy and confirms a 6.1 Ma age for the Maeotian-Pontian boundary in the Dacian Basin, in analogy with the Caspian and the Black Sea Basins (van Baak et al., 2016; Rostovtseva and Rybkina, 2017).

The age of the Khersonian-Maeotian boundary has been highly debated, with attributed ages differing as much as 3 Myr: 10.5 Ma (Matenco et al., 2003), 9.3 Ma (Nevesskaya et al., 2003), 7.6 Ma (Rybkina et al., 2015; Palcu et al., 2019b). In the Black Sea, the Khersonian- 
Maeotian boundary was magneto- and cyclostratigraphically dated at 7.6 Ma (Trubikhin, 1989; Rybkina et al., 2015; Rostovtseva and Rybkina, 2017). In the Dacian Basin, initiation of the Maeotian transgression was dated at $7.65 \mathrm{Ma}$ (slightly below C4n.1n - C4n.1r polarity reversal) (Palcu et al., 2019b).

There are accordingly two possible options for correlation of our normal zone N1. The most likely correlation, in our opinion, would be to chron C4n.1n, which would be in accordance with a Khersonian-Maeotian boundary near 7.6 or 7.65 Ma (Option 1). An alternative might be to correlate to chron C3Bn (Option 2), or any of the other normal chrons between C3Bn and C4n.1n (Fig. 1.14). Option 1 results in a sedimentation rate of $0.78 \mathrm{~m} / \mathrm{kyr}$, subsequently gently decreasing to $0.67 \mathrm{~m} / \mathrm{kyr}$ and $0.65 \mathrm{~m} / \mathrm{kyr}$ (Fig. 1.14). Option 2 results in an initial sedimentation rate of $1.23 \mathrm{~m} / \mathrm{kyr}$ with a subsequent decrease down to $1.05 \mathrm{~m} / \mathrm{kyr}$ and then to $0.65 \mathrm{~m} / \mathrm{kyr}$. The lower Maeotian interval in Slănicul de Buzău does not show any abrupt lithological changes (Fig. 1.4). Correlation to chron C4n.1n (Option 1) does not lead to any severe changes of sedimentation rates and is thus considered as our preferred option. Moreover, with this correlation, the remainder of normal chron C3An.2n would completely fall in the unexposed interval between 734 and $916 \mathrm{~m}$ and C3Bn as well as C3Br.1n would fall in the unexposed interval between 370 and $601 \mathrm{~m}$. In case of correlation option 2, on the other hand, these normal chrons should fall in exposed parts of the section that show according to our results reversed polarity. It is thus most logical to correlate to C4n.1n (Option 1), which results in a $7.63 \pm 0.05 \mathrm{Ma}$ age for the Maeotian-Khersonian boundary $(150.8 \mathrm{~m})$ in the Slănicul de Buzău section, in close accordance with previous results.

\subsubsection{Palaeoenvironmental reconstruction from Slănicul de Buzău and its relation with the evolution of the Eastern Paratethys}

\subsubsection{Coastal plain deposition during the late Khersonian lowstand}

During the Khersonian, the climate in the Eastern Paratethys region became arider, and open steppe-like landscapes dominated, where xerophytic-type vegetation developed (Ivanov et al., 2011). This period, also known as the Khersonian drying, provoked a disruption of the sensitive water budget that resulted in high amplitude base-level fluctuations (Popov et al., 2010; Ivanov et al., 2011; Palcu et al., 2019b). The facies trend in the Slănicul de Buzău section

Figure 1.15 (next page) Magneto-, bio- and sequence-stratigraphic reconstructions of the palaeoenvironmental evolution along the Slănicul de Buzău section during the Khersonian-Maeotian with characteristic depositional environments, mollusc fauna and estimated salinity in proximal and distal setting. HST - highstand system tract, TST - transgressive system tract, MRS - maximum regressive surface, MFS - maximum flooding surface. The colour meaning in the facies association column is shown in the legend of Figure 1.4. 


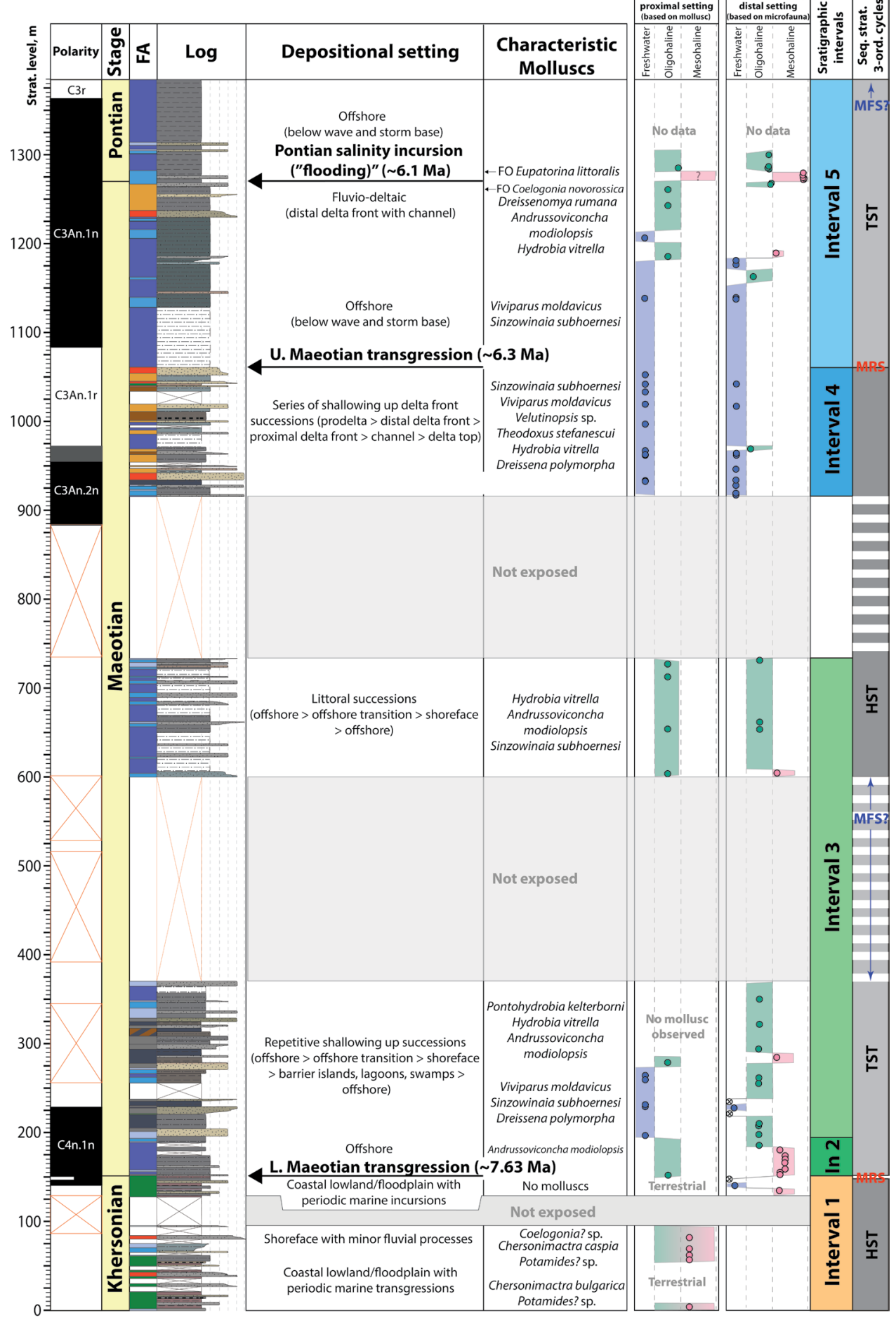


reflects two intervals (0-62.2 $\mathrm{m}$ and 127.5-150.8) with well-developed palaeosols separated by an interval with littoral (offshore-shoreface) facies (Fig. 1.15). Stratigraphically, this interval corresponds to the uppermost Khersonian lake level lowstand indicated by Popov (2006). The Chersonimactra bulgarica biozone spans the upper Khersonian (Kojumdgieva et al., 1989). The indicative species, Chersonimactra bulgarica and Ch. caspia are widely distributed in our section within the first red interval and in the subsequent interval with littoral deposits (Fig. 1.15). From a sequence stratigraphic point of view, the uppermost Khersonian, which is palaeosol dominated, can be seen as a maximum regressive level, i.e. a sequence boundary.

\subsubsection{Early Maeotian transgression and establishment of a littoral environment}

The great Khersonian drying was terminated by the widely recognised Maeotian transgression that was caused by a climatically driven switch to an overall positive hydrological balance of the Eastern Paratethys (Palcu et al., 2019b). At the onset of the Maeotian, the depositional environment in the Slănicul de Buzău area suddenly changed from the coastal plain characteristic for the Khersonian (SI1) to an offshore setting (SI2). The offshore interval (SI2) contains abundant Ammonia beccarii, an event that is also characteristic for the lowermost Maeotian in other parts of the Eastern Paratethys and is known as the "Ammonia acme zone" (Popescu, 1995; Pinchuk, 2006). The fossil record in the central Euxinian Basin is taxonomically richer and besides Ammonia beccarii also contains numerous species of the Quinqueloculina and Cassidulina genera as well as abundant Tamanicella lapidosa bryozoa (Popov et al., 2016), which indicate a higher salinity. The salinity, based on the co-existence of certain microfauna groups in the entire lower Maeotian of the Euxinian Sea (Taman Peninsula) is estimated between 7-13\%o (Popov et al., 2016), while we estimate salinity for the lowermost Maeotian offshore interval (SI2) along Slănicul de Buzău between 6-10 \%o, and for the rest of the lower Maeotian (SI3) between 3-5 \%o (oligohaline) (Fig. 1.15). From a sequence stratigraphic point of view, SI2 can be seen as the onset of a transgressive systems tract that will continue into SI3. The lower part of SI3 comprises alternating offshore, shoreface, barrier and back-barrier lagoon deposits, which frequently occur in transgressive settings. We expect the maximum flooding surface of the SI2-SI3 transgressive systems tract to be located in the probable mudstone dominated unexposed interval between 371 and $601 \mathrm{~m}$. The upper part of SI3 then comprises the start of the highstand systems tract, i.e. the onset of gradual progradation of the sediment system, which will culminate in SI4.

\subsubsection{Arrival of the Balta Delta in the late Maeotian}

The upper Maeotian (SI4) of Slănicul de Buzău is characterised by delta-front cyclicity and prevalence of freshwater microfauna in both delta-front and prodelta depositional settings. The littoral environments that dominate the lower Maeotian (SI3) indicate that, at that time, our study area was located along the shore, but not yet at the mouth of a major delta. The delta 
front became located in the Slănicul de Buzau area between $\mathrm{m} \sim 6.5$ and $6.3 \mathrm{Ma}$, likely due to progradation of the Balta Delta along the axis of the East Carpathian Foreland (Matoshko et al., 2016). This indicates that sediment supply outpaced creation of accommodation space. From a sequence stratigraphic point of view, this would be characteristic for the late highstand systems tract and the following regression. Maximum regressive conditions occurred at the top of the interval with progressively shallower delta-front parasequences, i.e. at the thick channel sandstone at $1061 \mathrm{~m}$. This is the second sequence boundary identified in the investigated section.

The domination of freshwater fauna in SI4 is quite striking (Fig. 1.15). Freshwater fauna furthermore dominates the thick offshore deposits of the directly overlying lower part of unit SI5 (see below). Low brackish microfauna occurs only very occasionally in the most distal settings of SI4 and the lower part of SI5 (Fig. 1.15). This distinctive freshening of the Dacian Basin in the Late Meotian points at a restricted connection with the brackish Euxinian Basin (Popov et al., 2016) and strong control of the basinal water budget by freshwater riverine input. This may have been caused by the progradation of the Balta Delta: Sediment supplied by this delta may have narrowed or closed the gateway between the Dacian Basin and the Euxinian Basin leading to restriction and subsequent freshening of the Dacian Basin.

\subsubsection{Latest Maeotian freshwater transgression and early Pontian "flooding"}

The shallow-water deltaic deposits of SI4 are overlain by a thick succession of offshore mudstones (SI5), indicating a significant rise in relative base-level (Fig. 1.15). This event, which we interpret as a major transgression, started at $6.3 \mathrm{Ma}$ (correlated to C3An.1r), with maximum water levels reached sometime in the early Pontian for which high base-levels are known from all around the Eastern Paratethys (Popov et al., 2006; 2010). The offshore deposits of the lower part of SI5 contain freshwater molluscs and microfauna, meaning the Dacian Basin remained fresh during the initial transgression (Fig. 1.15). The contemporaneous fossil record of the neighbouring Euxinian Basin, on the other hand, contains brackish water fauna (Popov et al., 2016). This difference in the faunal assemblages of the two basins indicates that, at least during the early part of the transgression, freshwater input to the Dacian Basin and its restriction from the Euxinian Basin were sufficient enough to keep the basin's water fresh.

The late Maeotian transgression appears along with a remarkable increase in sedimentation rate from $0.65 \mathrm{~m} / \mathrm{ky}$ within C3An.1r chron to $1.26 \mathrm{~m} / \mathrm{ky}$ within C3An.1n (Fig. 1.14). The Slănicul de Buzău section is located on the western flank of the Focşani Depression - a depocentre that experienced enhanced subsidence during the latest Miocene-Pliocene (Leever, 2007) as expressed in a markedly thicker depositional record compared to the western Dacian Basin (Jipa and Olariu, 2009). Around the Focşani Depression, a similar increase of sedimentation rate from $0.6 \mathrm{~m}$ to $1.5 \mathrm{~m} / \mathrm{ky}$ was previously detected within the C3r chron (Pontian) along the Putna and Râmnicu Sărat sections (Vasiliev et al., 2004). The 
Bizdidel section, which is located more to the west, outside the Focşani Depression, shows a sedimentation rate of only $0.3 \mathrm{~m} / \mathrm{ky}$ within the C3An.1n chron, which is almost five times slower than at Slănicul de Buzau. This increase of sedimentation rates and the concurrent deepening of the depositional environment that we register along Slănicul de Buzău were likely linked to amplification of subsidence in the Focşani Depression, which rapidly augmented accommodation space.

Higher up in the section, from $1166 \mathrm{~m}$ upwards, we discovered the first influxes of brackish water microfauna (Fig. 1.6) and molluscs (Table 1.2, $1186.6 \mathrm{~m}$ ), which initially alternate with freshwater taxa. The presence of Typhlocyprella sp. indicates the first pulses of brackish water from Lake Pannon. Modelling of the connection between Lake Pannon and the Dacian Basin suggests at least a one-way flow from the upstream Lake Pannon to the Dacian Basin at the Maeotian-Pontian transition (Leever, 2007). The one-way flow is also supported by the absence of Eastern Paratethyan faunistic groups in Lake Pannon at that time (Magyar et al., 1999).

At $1265 \mathrm{~m}$, the occurrence of Coelogonia novorossica preludes the Maeotian-Pontian transition (Roshka, 1973; Stoica et al., 2007; Stoica et al., 2016). At 1270 m, an abundant mesopolyhaline fauna assemblage with the foraminifers Ammonia, Porosononion, Quinqueloculina and Streptochilus occurs. This short influx of "marine" microfauna at 6.1 Ma (Fig. 1.11, 1.15) is known as the "Pontian flooding" and has been traced in all parts of the Eastern Paratethys: in the Dacian Basin (Stoica et al., 2013), the Euxinian Basin (Taman Peninsula, Zhelezniy Rog section) (Krijgsman et al., 2010), Western Caucasus (Maissuradze, 1988) and Azerbaijan (Van Baak et al., 2016). The occurrence of this assemblage is linked to the establishment of a short connection between the Mediterranean, Eastern Paratethys and possibly Lake Pannon (Krijgsman et al., 2010; Stoica et al., 2013). Given that our results along Slănicul de Buzău indicate that the transgressive systems tract started at $6.3 \mathrm{Ma}$, well before the appearance of foraminifera at 6.1 Ma, it would in our opinion be better to change the name of the foraminifer level from "Pontian Flooding" into "Pontian Salinity Incursion".

The interval with foraminifera is shortly followed (at $1279 \mathrm{~m}$ ) by the appearance of typical early Pontian oligohaline molluscs and ostracods: Pontoniella acuminata, Candona (Hastacandona) lotzy, Candona (Hastacandona) hysterica, Candona (Zalaniella) venusta etc. (Fig. 1.11). This fauna, which originated in Lake Pannon, used the Dacian Basin as a springboard to spread all over the Eastern Paratethys at the onset of the Pontian (Stevanovic et al., 1989; Popov et al., 2006; Grothe et al., 2018), and eventually entered the Mediterranean Basin in the latest Messinian (Stoica et al., 2016). The first occurrence of molluscs that biostratigraphically defines the early Pontian is situated $9 \mathrm{~m}$ above the "Pontian Salinity Incursion" that, considering the high sedimentation rate, means a delay of $\sim 6 \mathrm{ky}$. We choose to place the chronostratigraphic base of the Pontian at foraminifera bearing level, which is $6.1 \mathrm{Ma}$ old. 


\subsection{Conclusions}

Our integrated magneto-biostratigraphy, with observations of sedimentary facies and fossil fauna distribution, contributes to a better understanding of the palaeoenvironmental evolution of the Dacian Basin during the late Miocene (late Khersonian-early Pontian) interval.

In the uppermost Khersonian, we revealed a low relative base-level marked by the development of red palaeosols shortly interrupted by an interval with offshore-shoreface environments. A monospecific Khersonian mollusc assemblage with Chersonimactra bulgarica is widely present in the Khersonian deposits but disappears in the upper palaeosol interval. The Khersonian was terminated by the Maeotian transgression that is correlated here to Chron C4n.1n and dated at $7.63 \mathrm{Ma}$. The transgressive interval contains abundant Ammonia beccarii foraminifera and brackish water ostracods. The early Maeotian comprises shoreface, barrier and back barrier-lagoon environments. The presence of freshwater molluscs in shallow water facies such as shoreface and barrier islands, but oligohaline microfauna in deeper-water facies indicative of offshore to offshore transition environments suggests that the deeper basin remained brackish, whereas marginal environments felt a distinctive freshwater influence. In the late Maeotian (6.5-6.3 Ma), the area was characterised by delta-front deposition with abundant freshwater molluscs and freshwater microfauna. An abrupt replacement of deltaic deposits by relatively deepwater offshore ones subsequently provides evidence for a major transgression that started in the late Maeotian at 6.3 Ma. Several pulses with brackish water microfauna with Typhlocyprella sp. follow the initial rise in base-level and suggest a periodic overflow of Lake Pannon into the Dacian Basin. The Maeotian-Pontian boundary is marked by a short-duration influx of a meso- polyhaline microfaunal assemblage dominated by planktonic and benthic foraminifera. This event is commonly known as the "Pontian Flooding" but might better be named "Pontian Salinity Incursion" given that the transgression started in the late Maeotian. Our high-resolution magneto-biostratigraphic dating places the Pontian Salinity Incursion at 6.1 $\mathrm{Ma}$ and indicates that it was synchronous throughout the entire Eastern Paratethys. The typical Pontian mollusc and ostracod assemblages first appear $9 \mathrm{~m}$ above the salinity incursion.

Our palaeoenvironmental reconstruction highlights the importance of an integrative approach. Simultaneous analyses of sedimentary facies, micro- and macrofauna allow constraining better a precise position of fossils in the depositional environment, which leads to an improved understanding of the evolution of salinity in the basin and along its margin. This approach is particularly crucial in semi-isolated marginal basins like the Eastern Paratethys and the Dacian Basin, which combine features of marine basins as well as freshwater lakes.

\subsection{Acknowledgements}

We thank our colleagues from CASP and Paleomagnetic laboratory "Fort Hoofddijk" for scientific support and advice during the writing of this paper. We also thank Pierre Polard-Taine for help with the palaeomagnetic measurements. We would also like to give special thanks to Dr 
Sergey Popov (GIN RAS, Moscow) and two other anonymous reviewers for valuable comments that allowed significantly improve the manuscript. This research is part of the PRIDE project (Pontocaspian RIse and DEmise), which was funded by the European Union's Horizon 2020 research and innovation program, under the Marie Skłodowska-Curie Action (grant agreement № 642973). 
From Khersonian Drying to PONTIAN “Flooding" 


\section{Part}

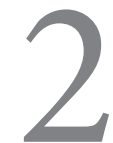

The hidden Paratethyan Affinity: Age CONSTRAints, DEPOSITIONAL ENVIRONMENTS AND FAUNAL RECORD of the Neogene Denizli Basin (SW Anatolia, Mio-Pliocene). 


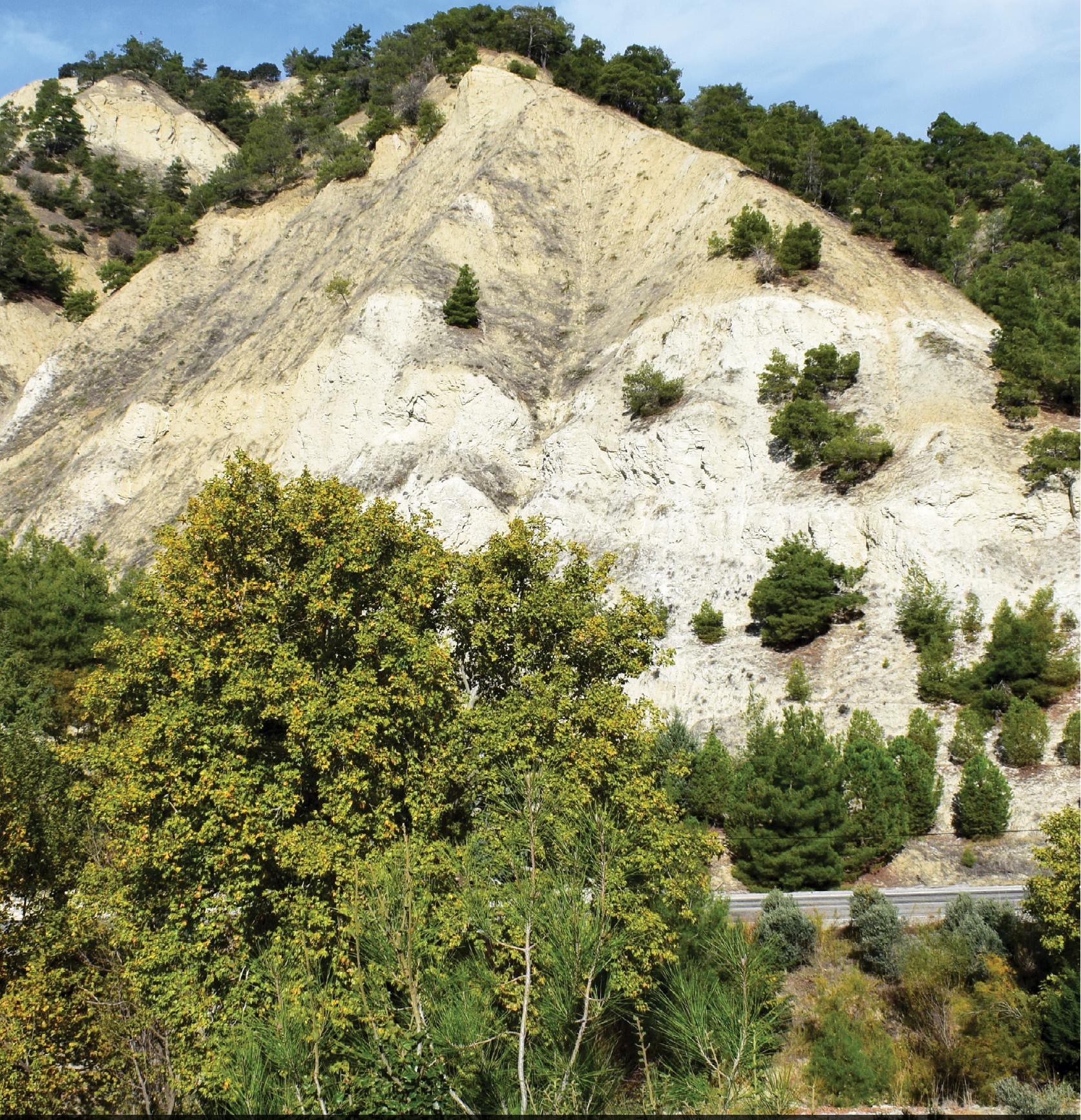

The interval in the Kolankaya Formation showing an abrupt lithological change from white lacustrine marlstones to prograding delta-front siltstones followed by alluvial fan sandstones and conglomerates. This event was dates between 5.6-5.7 Ma and is accompanied by a strong 


\section{2}

\section{CONSTRAINING BIOGEOGRAPHIC EVOLUTION}

AT CONTINENTAL CROSSROADS: AGE AND ENVIRONMENTAL EVOLUTION OF THE LATE Neogene Denizli Basin succession (TURKEY).

In preparation:

Lazarev, S., Wesselingh, F.P., Rausch, L., Alçiçek, M.C., Neubauer, T.A., Stoica, M., Hoyle, T.M., Sangiorgi, F., Abels, H.A., van Baak, C.G.C., Krijgsman, W., 2020. Constraining biogeographic evolution at interbasinal crossroads: Age and environmental evolution of the Late Neogene Denizli Basin succession (Turkey). 


\section{Abstract}

Aquatic biodiversity hotspots often emerge in regions with active tectonism, diverse climate conditions and complex basin configurations enabling episodic biotic isolation and exchange. The Anatolian microcontinent, located between the Mediterranean and Paratethyan regions, has been considered as a cradle of biodiversity for continental aquatic organisms. The Denizli Basin of SW Anatolia contains a late Neogene "Didacna" fauna that potentially contributed to the modern Pontocaspian faunas of the Black Sea-Caspian regions. These Pontocaspian faunas are the remainders of the vast Paratethyan systems, but the real origins, evolution and migration pathways of these faunas are enigmatic. Here, we present an integrated magnetobiostratigraphic framework for the Kolankaya Formation of the Denizli Basin to better assess the role of the Denizli faunas as a potential predecessor to modern Pontocaspian faunas. We show that the Denizli successions contain two distinct lake phases (Kolankaya I and II, the latter contains the Didacna fauna). The late Miocene Kolankaya I fauna, found in many basins in SW Anatolia, is dated to be older than 5.6 Ma. A massive disruption between the two lake phases is dated at $\sim 5.6 \mathrm{Ma}$ and is possibly related to the peak event of the Mediterranean Messinian Salinity Crisis (MSC). The establishment of the Kolankaya II fauna is younger than 5.6 Ma. This fauna is endemic to the Denizli basin and indicates regional tectonic compartmentalisation. The abrupt faunal turnover at 5.6 Ma shows the interplay of tectonics, climate and basin configuration on the evolution of Anatolia as a centre of diversifications. Our stratigraphic constraints, which need further confirmation from other Anatolian lake basins, lead to a better understanding of critical faunal transitions and palaeogeographic pathways in Anatolia and the role of Messinian palaeogeographic events in the Mediterranean-Paratethyan region.

\subsection{Introduction}

Southwestern Anatolia (Turkey) is a continental aquatic biodiversity hotspot with GraecoAnatolian and Pontocaspian faunal elements (Wilke et al., 2008; Wesselingh et al., 2008; Büyükmeriç \& Wesselingh, 2018; Rausch et al., 2020; Sands et al., 2020). The origin of these faunas is not well understood. Within the region, the Denizli Basin contains a Neogene succession hosting endemic faunas with Paratethyan and Pontocaspian affinities (Wesselingh et al., 2008; Alçiçek et al., 2015; Rausch et al., 2020). These faunas reveal a close relation with Neogene Paratethyan groups as well as modern endemic groups of the Caspian and Black Sea region and their presence in Denizli raises questions on the role of Anatolia in shaping the regional biota. However, the biogeographic significance of the Denizli fauna remains unclear due to the paucity of stratigraphic age constraints.

The Denizli Basin is located in the Aegean-west Anatolian region, which is separated by two vast water realms - the Mediterranean and the Eastern Paratethys (Fig. 2.1). Major regional palaeoenvironmental and biogeographic reorganizations occurred during the Mio-Pliocene transition (Roveri et al., 2014a; van Baak et al., 2017). The isolation of the Mediterranean 
from the Atlantic Ocean triggered the Messinian Salinity Crisis (MSC) that transformed the Mediterranean into a salt giant, sustained enhanced drying in the region and wiped off numerous Mediterranean faunal groups (Krijgsman et al., 1999; Roveri et al., 2014a; Flecker et al., 2015; Krijgsman et al., 2018). At the final Messinian phase, the Paratethyan environments and faunas shortly expanded into the Mediterranean (the Lago Mare phase) bringing endemic brackish ostracods and molluscs from the Black Sea region as far as the Malaga Basin near Gibraltar (Taviani et al., 2007; Guerra-Merchán et al., 2010; Stoica et al., 2016). Re-opening of Gibraltar, and the associated Zanclean flooding, made the Paratethyan invasive groups in the Mediterranean disappear and established modern marine conditions there (Roveri et al., 2014a; Micallef et al., 2018).
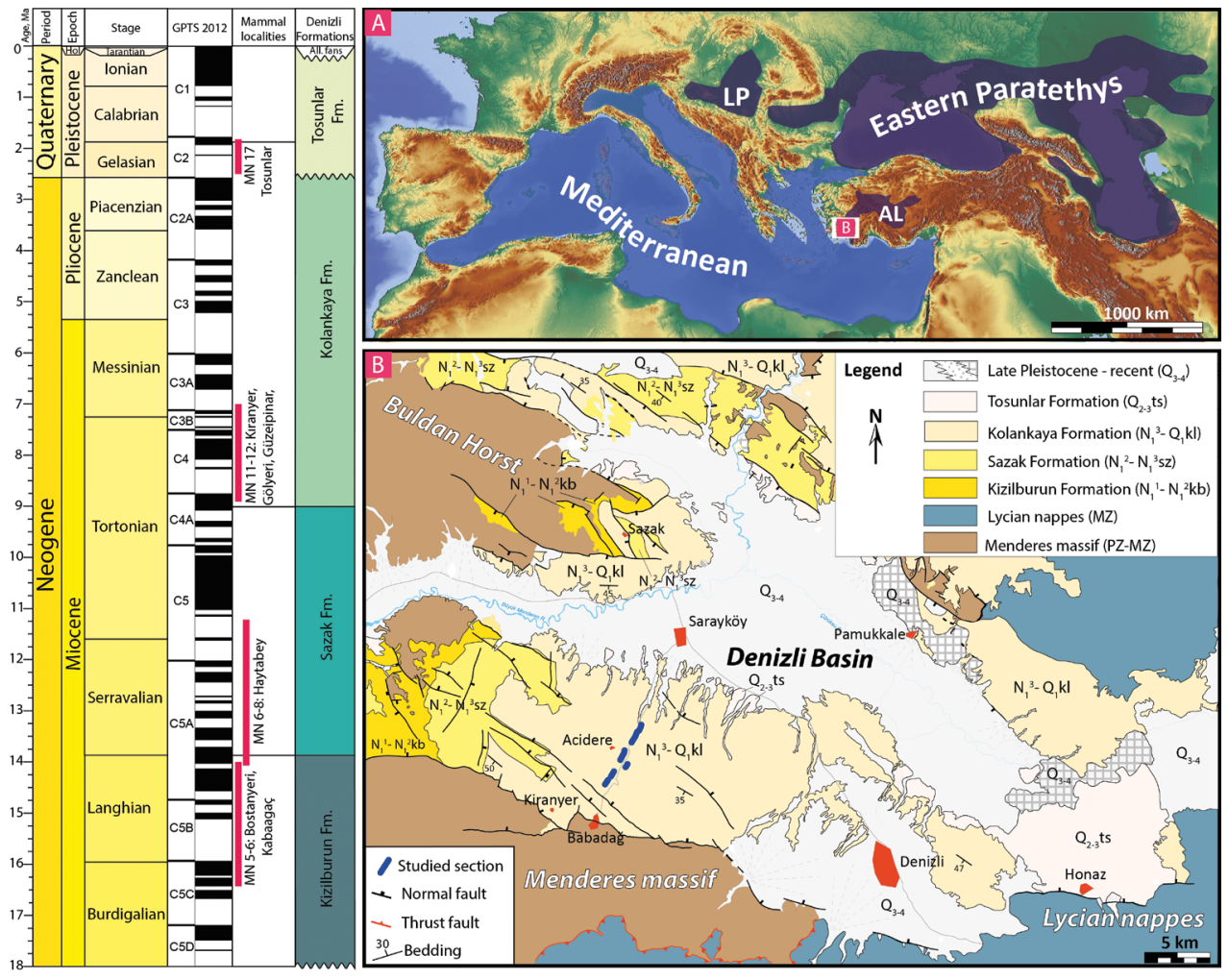

Figure 2.1 Regional lithostratigraphic formations and mammal localities of the Denizli Basin (Yalçınlar, 1983; Saraç, 2003; Kaymakci, 2006; Doğan et al., 2020)correlated to the Geological Time Scale (Hilgen et al., 2012). Location of the studied section: A. In the Paratethyan region (LP = Lake Pannon; $A L=$ Anatolian lakes). The palaeogeographic map is based on the outlines of Popov et al. (2004). B. In the Denizli Basin. Regional time scale and geological map are modified after Sun (1990). 
The impact of such intense biogeographic reorganisations on the continental aquatic biota of adjacent regions such as west Anatolia is not well understood. The interbasinal exchanges of aquatic faunas discovered in the geological outcrops across the Aegean Basin (Popov and Nevesskaya, 2000) suggest that starting from the Tortonian, the Mediterranean and the Eastern Paratethys were episodically connected via the Aegean-west Anatolian region. However, potential aquatic corridors in Anatolian basins have not been detected as ongoing tectonism has obliterated or covered the sedimentary successions. Robust age constraints together with a thorough biogeographic study of the fossil record of the western Anatolian-Aegean basins may shed light on the nature, duration and regional impact of the Paratethyan-Mediterranean connectivity history. This is also imperative for the emergence of the modern Anatolian biodiversity hotspot.

In this paper, we study a $1.4 \mathrm{~km}$-thick section of the late Neogene Kolankaya Formation in the Denizli Basin of SW Anatolia (Fig. 2.2). The Mio-Pleistocene sedimentary succession of this basin is subdivided into five formations with rough age constraints derived from regional small mammal faunas (Fig. 2.1) (Yalçınlar, 1983; Saraç, 2003; Kaymakci, 2006; Alçiçek, 2010; Doğan et al., 2020). The well-exposed 3D basin architecture and the aquatic and terrestrial fossil assemblages represent an excellent but underexplored archive of the palaeoenvironmental evolution of the region. Here, we use a combination of palaeomagnetic and biostratigraphic analyses to provide more robust age constraints, and sedimentary and palaeoecological observations to characterise successive palaeoenvironments. Mollusc, ostracod and dinoflagellate biota are reported, and their biogeographic affinities assessed. The aim of this paper is to date the occurrence of Pontocaspian/Paratethyan type of faunas in the Denizli Basin in order to evaluate the role of Anatolian basins in general and the Denizli Basin in particular in the evolution of these biotas.

\subsection{Geological setting}

\subsubsection{Mediterranean, Paratethyan and Aegean-Anatolian regions during Messinian}

The complex Cenozoic tectonic and palaeogeographic evolution of western Eurasia is the result of an ongoing collision of the African, Arabian and Eurasian plates. Around the Eocene - Oligocene transition, the break-up of the Tethys Ocean resulted in the emergence of Mediterranean and Paratethys basins (Rögl, 1999; Schulz et al., 2005). In between, several continental microplates developed that characterise the Aegean-Anatolian region. The presence of Cenozoic volcanic arcs, accretionary complexes, metamorphic cores and thrust-fold belts in the region attests to the complex and dynamic regional tectonic evolution (van Hinsbergen et al., 2016; Koç et al., 2017). Being at the crossroad of several continents, the Aegean-Anatolian region served at the time as a semi-continuous land bridge between Africa, Europe and Asia allowing migration of continental biotic groups (Rögl, 1999; Vasilyan et al., 2019). During 
short episodes, the region also hosted aquatic corridors with the Mediterranean and Paratethys (Wesselingh et al., 2008)

During the late Miocene, climate regimes in western Eurasia became dryer (Herbert et al., 2016). At the same time, the Atlantic-Mediterranean connections became tectonically restricted (Roveri et al., 2014a; Flecker et al., 2015; Capella et al., 2018). The Eastern Paratethys at the time was an endorheic mesohaline basin covering the Caspian, Euxinian (Black Sea) and Dacian basins (Popov et al., 2006; van Baak et al., 2017). During the Messinian, the Aegean-Anatolian region was characterised by regional extension that resulted in the formation of a complex basin configuration (ten Veen, 2009). Fossil occurrences show the affiliation of the northern Aegean and the Eastern Paratethys from the Tortonian onwards (Gramann and Kockel, 1969; Popov and Nevesskaya, 2000; Popov, 2004).

Conspicuous change in the Paratethys region occurred at 6.1 Ma when the freshwater faunal record of the Maeotian regional stage was interrupted by an influx of marine microfauna, marking the beginning of the Pontian regional stage. This event, known as Pontian flooding or Pontian Salinity Incursion is observed in all Eastern Paratethyan affinities (Dacian, Euxinian and Caspian Basins) (Krijgsman et al., 2010; Stoica et al., 2013; Grothe, 2016; van Baak et al., 2016; Lazarev et al., 2020). Strontium isotope ratios and organic geochemistry data suggest a Mediterranean origin for this incursion (Vasiliev et al., 2015; Grothe et al., 2020). Immediately after the Pontian salinity incursion, the Eastern Paratethys was invaded by new Pontian faunal assemblages (mollusc, dinoflagellates, ostracods) originating from Lake Pannon (Central Paratethys) (Magyar et al., 1999; Grothe et al., 2018).

The latest Miocene palaeogeographic evolution of the region was inextricably linked to the MSC - the time of a substantial base-level drop in the Mediterranean and accumulation of kilometres thick evaporites (e.g. Roveri et al., 2014a). The MSC developed in three stages: Stage 1 (5.97-5.6 Ma) - formation of gypsum in marginal sub-basins; Stage 2 (5.6-5.55 Ma) - the culmination of a crisis characterized by precipitation of halite; Stage 3 (5.55-5.3 Ma) - rebound of a crisis and Lago Mare (Roveri et al., 2014a; Flecker et al., 2015).

Disruption of the Mediterranean water budget during the MSC, superimposed on the late Miocene global climatic cooling, impacted the neighbouring Aegean-Anatolian region and the Eastern Paratethys as well. In Central Anatolia, a subtle precipitation decrease was revealed in the isotopic record of the Kangal Basin (Meijers et al., 2018). The MSC had a much stronger impact on the Eastern Paratethys, where a profound $50 \mathrm{~m}$ water level drop occurred around 5.6 $\mathrm{Ma}$ (Krijgsman et al., 2010). The positive hydrological budget of the Eastern Paratethys domain generated an overspill of anomalohaline water into the nearly-desiccated Mediterranean (Marzocchi et al., 2016). Various Paratethyan faunal groups (Pontian molluscs and ostracods) consequently migrated into the Mediterranean during the Lago Mare stage (5.42-5.3 Ma) of the MSC (Taviani et al., 2007; Roveri et al., 2014b; Stoica et al., 2016). In the Aegean - west Anatolian region, Pontian molluscs were discovered in Souvalia (Aegina Island), the Tracones 
Formation (south of Athens), the Thessaloniki region (Popov and Nevesskaya, 2000) and the Strimon Basin (Gramann and Kockel, 1969). The Paratethyan-Mediterranean aquatic corridor must, therefore, have been located in the Aegean region.

\subsubsection{Tectonic evolution and Neogene infill of the Denizli Basin}

The Denizli Basin is a WNW-ESE-oriented graben type basin located in SW Anatolia (Fig. 2.1). The basin belongs to a larger-scale Aegean - west Anatolian extensional province whose structural evolution is determined by two major plate tectonic processes: 1) roll-back of the Aegean slab initiated around $25 \mathrm{Ma}$ and resulted from subduction of the African plate below the Eurasian plate (Le Pichon et al., 1982; Gautier et al., 1999) and westwards escape of the Anatolian Block along the North and East Anatolian Fault Zones (Şengör and Yilmaz, 1981). The extensional processes in SW Anatolia were expressed in the exhumation of the metamorphic core complex - the Menderes Massif and its subsequent segregation into three sub-massifs: the Northern (Gördes), Central, and Southern (Çine) Menderes Massif (NMM, CMM and SMM respectively) (van Hinsbergen, 2010a). CMM exhumation occurred between 16 and $5 \mathrm{Ma}$. Domal uplift of the CMM led to the formation of the Alaşehir and Büyük Menderes basins along detachment faults (Veen et al., 2009; van Hinsbergen et al., 2010b). Possibly this also initiated the formation of the Denizli Basin that is located on the eastern flank of the CMM (Fig. 2.1). Ever since, the subsidence of the Denizli Basin became controlled by the Babadağ Fault Zone at the southern limit (Fig. 2.1) (Westaway, 1993; Alçiçek, 2007b).

The sedimentary infill of the Denizli Basin has been subdivided into four lithological formations, jointly referred to as the "Denizli Group" (Sun, 1990) (Fig. 2.1). The lower part of the late Burdigalian - late Langhian Kizilburun Formation, contains an alternation of conglomerates and reddish mudstones. The upper part consists of channelized conglomerates interbedded with siltstones, mudstones, limestones and coal lenses, where a micromammal assemblage attributed to MN 5-6 was found (Saraç, 2003), corresponding to age between 16.4 and 14.1 Ma (Hilgen et al., 2012). The following early Serravalian - early Tortonian Sazak Formation conformably overlies the Kizilburun Formation and is built of lacustrine deposits represented by alternating lacustrine marlstones, claystones and siltstones. In its upper part, cherty limestones with gypsum, gypsum arenite and organic levels are present (Alçiçek et al., 2007a). An MN 6-8 micromammal assemblage was found in the marginal part of the Sazak Formation (Saraç, 2003), indicating an age between 14.1 and 11.2 Ma (Hilgen et al., 2012). The late Tortonian - Piacenzian Kolankaya Formation (the subject of this study) conformably overlays the Sazak Formation and comprises alternating marlstones, siltstones and claystones. In its upper parts, sandstones and conglomerates become more common. Mammalian faunas from the lower part of the Kolankaya Formation are attributed to MN11-12 (Sickenberg and Tobien, 1971; Yalçınlar, 1983; Saraç, 2003; Doğan et al., 2020), suggesting an age between 8.9 Ma and 7 Ma (Hilgen et al., 2012). The Early Pleistocene Tosunlar Formation unconformably 
overlies the Kolankaya Formation and is composed of yellowish-brownish sandstone, siltstones, conglomerates, mudstone and clayey limestone (Doğan et al., 2020). A micromammal fauna from the Tosunlar locality was assigned to MN 17 (Yalçınlar, 1983; Kaymakci, 2006; Doğan et al., 2020) attributed to age between 2,5 and 1,8 Ma (Hilgen et al., 2012).

\subsection{Material \& methods}

\subsubsection{Section and logging}

Our study concerns a $1415 \mathrm{~m}$ long section within the Kolankaya Formation (Fig. 2.2). The

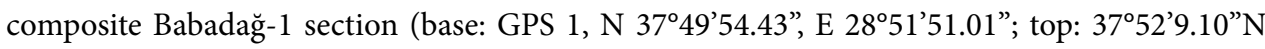
$28^{\circ} 53^{\prime} 42.60$ ”E) is located in the south-western part of the Denizli Basin along the Babadag Sarayköy road, $\sim 2.4 \mathrm{~km}$ to the NW from the town of Babadağ (Fig. 2.1). The section trends perpendicular to the SW basin margin that is delimited by the active WNW-trending Babadağ fault zone. The stratigraphic thickness was measured using Jacob's staff and for non-exposed intervals calculated using the parameters of bedding orientation, the distance between GPS points and their altitude.

\subsubsection{Magnetostratigraphy}

We collected 202 samples for magnetostratigraphic and rock magnetic property analyses, 182 of which were used for polarity determination. Laboratory procedures and analyses follow Lazarev et al. (2019). A local declination correction of $5^{\circ}$ was added (September 2015, https:// www.ngdc.noaa.gov). All palaeomagnetic measurements were performed at the Paleomagnetic laboratory "Fort Hoofddijk" (Utrecht, the Netherlands). Bulk magnetic susceptibility was measured on an AGICO Kappabridge MFK1-FA at room temperature and applied field of 200 $\mathrm{A} / \mathrm{m}$. For magnetostratigraphy, in total, 182 samples were stepwise thermally demagnetized with increments of $30-40^{\circ} \mathrm{C}$ in zero field conditions. Natural remanent magnetization (NRM) was measured on a horizontal $2 \mathrm{G}$ Enterprises DC SQUID cryogenic magnetometer (noise level $3 \times 10^{-12} \mathrm{Am}^{2}$ ). Samples were measured in multiple positions up to a maximum temperature of $580^{\circ} \mathrm{C}$ or until the remanent magnetisation was less than $10 \%$ from the initial NRM. Some samples with low magnetic intensity were measured down to $5 \%$ of the initial NRM if persistent demagnetization was still tending towards the origin. Interpretation of results, including determination of polarity and statistical analyses, was conducted using the online platform Paleomagnetism.org (Koymans et al., 2016). For the correlation of magnetic polarity patterns, we used the Geomagnetic Polarity Time Scale (GPTS) 2012 (Hilgen et al., 2012). Calculation of sediment accumulation rates was done by dividing the stratigraphic thickness of the magnetic polarity interval by its temporal duration based on GPTS 2012. 


\section{CHAPTER 2}
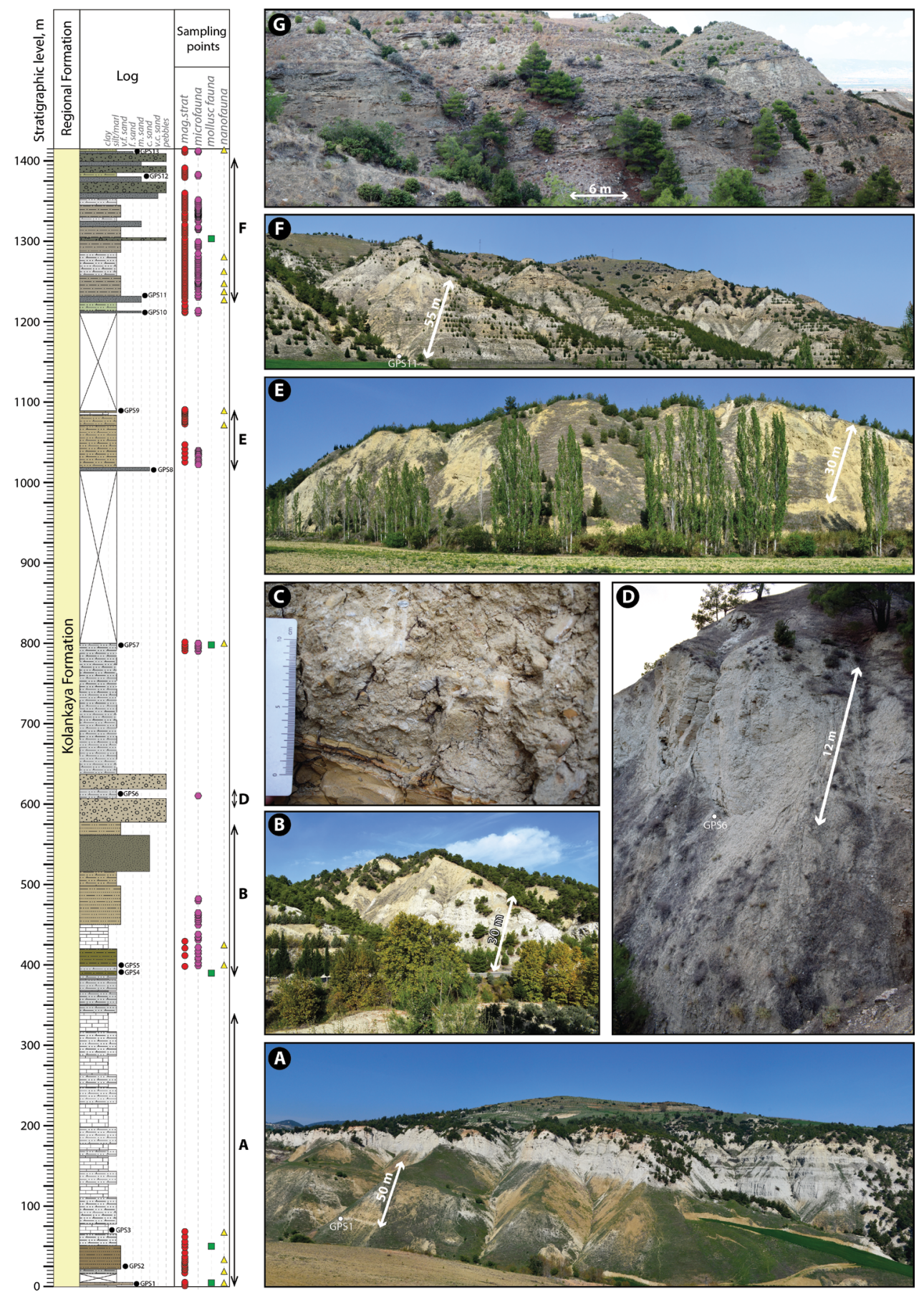

Figure 2.2 Composite log, sampling points and pictures of outcrops along the Babadağ-1 section. 


\subsubsection{Mollusc palaeontology}

Mollusc occurrences were documented in the sections, together with taphonomical characterisation (sorting, abrasion, occurrence of incompatible ecological taxa). The faunas from the upper part of the section have been extensively described before (Wesselingh et al., 2008; Alçiçek et al., 2015) and identification of species in the field was straightforward. For the lower parts of the section, faunas from three shell-rich levels were sampled in order to understand the species and their ecological and biogeographic signature. Sample from $5 \mathrm{~m}$ level is from a coarse-grained sand interval, and consists of a combination of larger gastropod specimens picked from the surface and small amount of fossiliferous sediment, washed over 0.5 $\mathrm{mm}$. Sample $50 \mathrm{~m}$ level yielded clay-silt with compacted and broken dreissenids. These samples were only cleaned and not washed (as the material would disintegrate). Sample from $390 \mathrm{~m}$ level contains about $3 \mathrm{~kg}$ of shell-bearing silts that were washed and sieved over $0.5 \mathrm{~mm}$.

\subsubsection{Ostracod palaeontology}

Ostracod data from two intervals within the Babadağ-1 section have been reported in Rausch et al. (2020). A further twenty-three samples were analysed following methods in that paper in order to increase the coverage of the entire section. Samples were recovered from fine-grained sediments (clayey siltstones and sandy limestones) and processed using standard micropalaeontological methods. Samples were boiled with sodium carbonate for disintegration before being washed and sieved over a battery of three sieves (2000-125-63 $\mu \mathrm{m})$. The dried residue was handpicked using a ZEISS-GSZ light microscope. Identifications are based on work by Moore (1961), Van Morkhoven, Frank P. C. M. (1962) and Hartmann (1959). Further information on the taxonomy is provided in the work of Livental (1929), Agalarova (1967), Agalarova et al. (1961), Yassini (1986), Jiřiček (1985) Krstić (1973, 1985, 1989), and Olteanu (1989). Species were correlated to specific environmental conditions to reconstruct the ecological evolution of the basin.

\subsubsection{Palynological analyses and dinoflagellate cyst as environmental indicators}

Fifteen samples were qualitatively analysed for dinoflagellate cysts (dinocyst) and other palynomorphs (pollen, freshwater and brackish water algae, such as Pediastrum and Botryococcus, and acritarchs such as Leiospheridium) (Supplementary Data 1). Samples were processed at Utrecht University using cold $\mathrm{HCl}(30 \%)$ to remove carbonates and cold $\mathrm{HF}$ (38 $\%)$ to dissolve silicates. Samples were shortly (five minutes) ultrasonicated and subsequently sieved through meshes $(125$ and $10 \mu \mathrm{m})$. The residues $(10-125 \mu \mathrm{m}$ fraction) were mounted on slides using glycerine jelly and sealed with lacquer. Slides were scanned for palynomorphs in order to indicate depositional environments. Identifications were made using several reference texts (Marret and Zonneveld, 2003; Mudie et al., 2001, 2002, 2017; Rochon et al., 1999, 2002; 
Shumilovskikh et al., 2013; Soliman and Riding, 2017; Süto-Szentai, 2000, 2010; Wall and Dale, 1973; Zonneveld et al., 2013, Reille 1993).

\subsubsection{Strontium isotope geochemistry}

Six samples were measured for strontium isotope $\left({ }^{87} \mathrm{Sr} /{ }^{86} \mathrm{Sr}\right)$ ratios in order to determine water sources (local, Paratethyan and Mediterranean waters have very different ratios). For each sample, 3-5 unaltered ostracod valves were used. Analyses were performed on a ThermoFinnegan Triton thermal ionization mass spectrometer (TIMS) at the University of Bristol. The Instrument performance was monitored using the NBS987 Sr standard, which produced an average of $0.710247 \pm 0.000005(2 \mathrm{SD}, \mathrm{n}=81)$ throughout the study. Procedural Sr blank is negligible based on replicate measurement of NBS987 Sr with each batch of column chromatography $(0.710248 \pm 0.000006, \mathrm{n}=41)$.

\subsection{Results}

\subsubsection{Section and logging}

Two coarsening upwards (CU) successions between $0 \mathrm{~m}$ and $635 \mathrm{~m}$ and 635-1415 $\mathrm{m}$ were documented (Fig. 2.2). The base of the lower succession consists of a $5 \mathrm{~m}$ interval represented by alternating marlstones and sandstones followed by a 10-m-unexposed interval. Upwards, a 7-m-thick grey marlstone interval occurs that gradually passes into a $27-30 \mathrm{~m}$-thick brown package of brown siltstones and fine-grained sandstones alternating in $5 \mathrm{~cm}$-thick beds. The overlying 5-450 $\mathrm{m}$ interval is dominated by white marlstones with indurated limestone beds (Fig. 2.2A), locally with brown thinly-bedded mudstones especially rich in mollusc fauna (398$420 \mathrm{~m}$, Fig. 2.2). At the $450 \mathrm{~m}$ level, a sharp contact between the white limestones and overlying yellowish brown sandy siltstones occurs (Fig. 2.2B). The contact is characterised by a $2 \mathrm{~m}$-thick breccia made of sub-angular marlstone clasts (Fig. 2.2C). The overlying sandy siltstones gradually pass into brown sandstone and eventually into a conglomerate interval (577-635 m) that contains a $12 \mathrm{~m}$-thick pale grey marlstone interval (607-619 m, Fig. 2.2D).

The base of the upper CU succession (635-1415 m) commences with pale grey marlstones $(635-800 \mathrm{~m})$ that overlay the conglomerates of the lower succession. The marlstones are exposed in small, discontinuous outcrops (GPS 7, Figure 2.2). The 800-1015 m interval lacks exposure, but given the morphology and the scree it is likely an unconsolidated fine-grained interval. The interval 1015-1090 m (Fig. 2.2E) is represented by yellowish-brown siltstones interbedded with fine-grained mica sandstones in beds of 1-10 cm. The interval 1090-1210 m lacks outcrops. The uppermost part of the section (1210-1415 m, Fig. 2.2F) is dominated by an alternation of brown marly siltstones and white marlstones locally interrupted by channelized conglomerate filled incisions that are very abundant around $1350 \mathrm{~m}$. Between 1350-1415 
$\mathrm{m}$, the conglomeratic incisions are dominant and separated by up to $15 \mathrm{~m}$-thick packages of marlstones and sandstones (Fig. 2.2G).

\subsubsection{Magnetostratigraphy}

The thermal demagnetization of 182 samples from the Denizli section revealed two NRM components. The first component is a low-temperature component (LTC) that demagnetizes in a temperature range $20-270^{\circ} \mathrm{C}$ (in some samples up to $360^{\circ} \mathrm{C}$ ) and has positive inclination values (Fig. 2.3A). The LTC is a dominant component in all studied samples and on average contributes to $80 \%$ of the total Natural Remanent Magnetisation (NTM). The average direction of the LTC component is: $\mathrm{D}=2.4^{\circ}, \mathrm{I}=53^{\circ}, \mathrm{k}=44, \alpha 95=1.6$ for $\mathrm{N}=171$ samples in geographic coordinates (Fig. 2.3B). The expected inclination for the present-day magnetic field in Denizli is $55^{\circ}$ (https://www.ngdc.noaa.gov, March 2016). We interpret the LTC as representing a secondary viscous magnetic overprint by the present-day field.

The second, high-temperature component fully demagnetizes in a temperature range 300 - $400^{\circ} \mathrm{C}$, trends towards the origin of the Z-plot and shows both positive (HT_N) and negative (HT_R) inclination values (Fig. 2.3A). The second component contributes on average, only $20 \%$ of the total NRM. The mean direction for high temperature reversed samples (HT_R) in tectonically corrected coordinates (tc) has parameters of $\mathrm{D}=173.8^{\circ}, \mathrm{I}=-55.6^{\circ}, \mathrm{k}=11.8, \alpha 95$ $=5.8$ for $\mathrm{N}=55$ samples (Fig. $2.3 \mathrm{C}$ ), while for high temperature normal samples $\mathrm{D}=4.7^{\circ}, \mathrm{I}=$ $45.6^{\circ}, \mathrm{k}=11.9, \alpha 95=5.1$ for $\mathrm{N}=71$ samples (Fig. 2.3D).

The mean inclination value of the HT_N group is about $10^{\circ}$ shallower than those in the antipodal reversed group (HT_R). To test for a potential inclination shallowing of the normal polarity samples, we applied the elongation/inclination method (E/I) that corrects for flattening using the TK03.GAD Field Model (Tauxe and Kent, 2004). The bootstrap test used in the E/I method shows an unflattened mean inclination of $57.18^{\circ}$ for the HT_N group (Fig. 2.3E). The application of this method to the reversed directions (HT_R) did not find intersections with the TK03.GAD polynomial (negative test). The HT_N samples were exclusively taken from the uppermost part of the section that has a distinctly different lithology with conglomeratic incisions and fine-grained intercalations (Fig. 2.2). We suspect that the accumulation of conglomerates in this part of the section could potentially result in higher compaction of finegrained intercalations that were the subject of our sampling. The reversal test of McFadden and McElhinny (1990) applied for both, HT_N and HT_R groups is positive, and we thus interpret the high-temperature magnetic component as primary and characteristic for the sedimentation age.

Our fragmented sampling revealed several reversed intervals (R1-R5), suggesting the domination of reversed polarities throughout the entire section limited by normal zones at the base and top (Fig. 2.4). The section begins with a small normal zone N1 $(0-11 \mathrm{~m})$ followed by reversed zone R1 $(11-66.8 \mathrm{~m})$. The next three sampled intervals have exclusively reversed 


\section{CHAPTER 2}

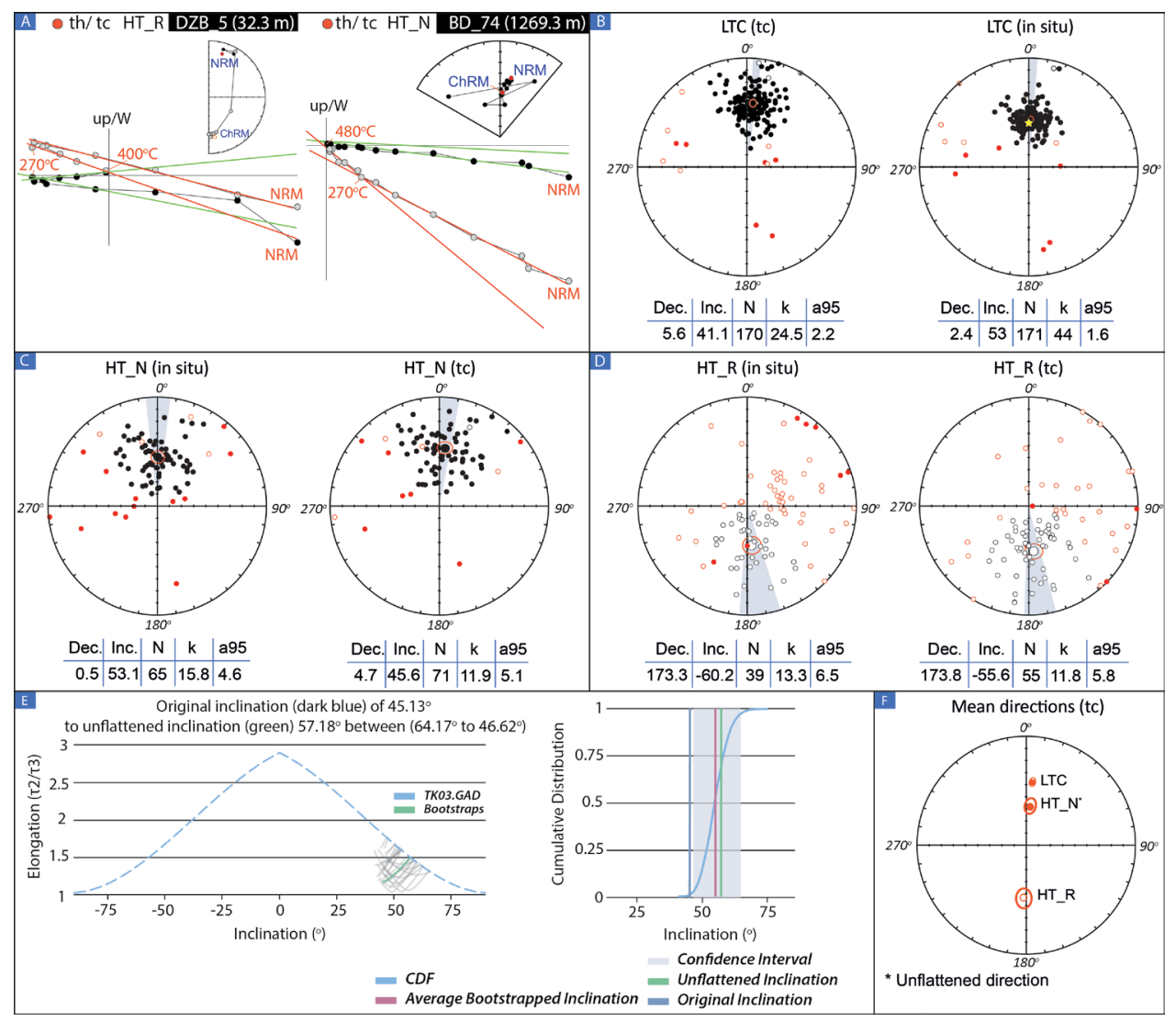

Figure 2.3 Zijderveld diagrams, equal area plots and bootstrap test diagrams of selected palaeomagnetic samples from the Babadağ-1 section. A. Zijderveld diagrams for samples with a representative 1 st magnetic component $\left(0-270^{\circ} \mathrm{C}\right)$ and reversed (left) and normal (right) 2nd components. Equal area plots in tectonic (tc) and geographic (in situ) coordinates for: B. Low-temperature directions (LTC); C. High-temperature normal (HT_N) directions; D. High-temperature reversed (HT_R) directions. E. Diagram of the bootstrap test used in the Elongation/Inclination method for determination of inclination shallowing in the HT_N group. F. Mean directions of all identified magnetic components. Abbreviations: th - thermally demagnetized; tc - tectonically corrected coordinates; in situ - geographic coordinates; NRM - natural remanent magnetization; ChRM - characteristic remanent magnetization; Dec. - declination; Inc. inclination; $\mathrm{N}$ - number of samples; $\mathrm{k}$ - precision parameter of Fischer, a95 - $95 \%$ cone of confidence.

polarity: R2 (398-428.5 m), R3 (790-799.2 m) and R4 (1025-1089.5 m). The uppermost part of the section contains reversed zone R4 (1211-1239.8 m) that passes into a $15 \mathrm{~m}$ interval of uncertain polarity that was defined as a grey zone (1239.8-1255.3 m). Above that, normal polarities extend to the top of the section (N2, 1255.3-1415 m). 


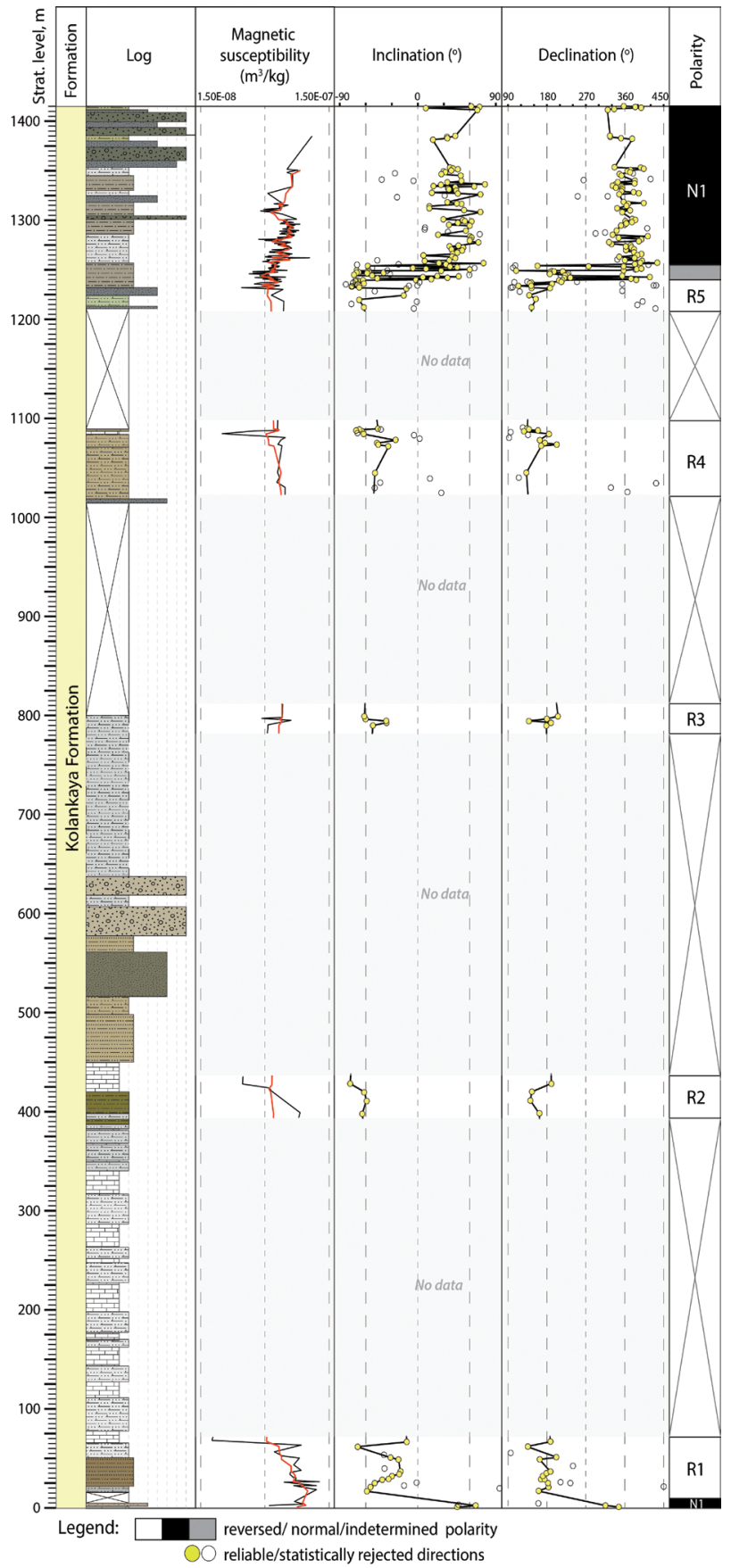

Figure 2.4 Magnetic polarity patterns identified in the Babadağ-1 section. Magnetic susceptibility curve is built in logarithmic scale: black line - values for each sample, red line - averaged 3. 
The bulk magnetic susceptibility fluctuates between $1.07 \mathrm{e}-07$ and $4.08 \mathrm{e}-08 \mathrm{~m}^{3} / \mathrm{kg}$. Generally, magnetic susceptibility follows the lithological trends in the section, demonstrating higher values in the lower- and uppermost parts of the section with dominantly siltstone/coarsegrained sediments and lower values in the middle part, dominated by marlstones/limestones (Fig. 2.4).

\subsubsection{Mollusc palaeontology}

\subsubsection{Mollusc fauna from Kolankaya I}

The fauna from the lower section interval $(0-640 \mathrm{~m})$ is dominated by Dreissena, Theodoxus, a range of hydrobiid and possibly bithyniid gastropods as well as a melanopsid species. Detailed taxonomic investigations are ongoing, but we estimate that about 23 species are present in the fauna. However, for many species, we are very uncertain as to their supraspecific classification.

Two species of Dreissena are present (Fig. 2.5). One of the species was attributed to Dreissena kairanderensis. Another species, Dreissena sp. 1, has flat and very wide shells and a smooth keel. The lower margin in some specimens has a shallow byssal depression. Separate morphological features of Dreissena sp. 1 resemble those of Pontocaspian Dreissena rostriformis, as well as D. kairanderensis and Dreissena rhodiensis.

Two or three species of Theodoxus occur in the material (Fig. 2.5). The first species Theodoxus percarinatus is the most common. Another species, Theodoxus sp. 1 shows higherspired specimens with a rounded-ovate outline and a similar pattering as found in some T. percarinatus. The third species, Theodoxus sp. 2 is a small, wide species with the flat upper side and remarkable strong axial ribs that are developed as papery lamellae. It has close morphological resemblance with T. pilidei from the late Miocene of the Dacian Basin and with T. gloeri from western Anatolia. Possibly the latter three species are very closely related, and they are subject of further study.

The freshwater melanopsid Esperiana cf. bergeroni is very common within the Kolankaya I fauna (Fig. 2.5). It concerns probably the same species as Melanopsis cf. bergeroni reported by Taner (1974). The attribution of our material to Esperiana is based on the similarity to extant Esperiana esperi, which is the only living representative of the genus Esperiana. Melanopsis species typically bear a fasciole and a distinctly thickened inner lip (especially anteriorly), which is lacking both in Esperiana and in the Denizli material.

Four Valvata species were found in the material (Fig. 2.5). A poorly preserved specimen is attributed to Valvata piscinalis. The second species concerns Valvata skhiadica. It was initially described from the Istrios Formation (late Serravallian to early Tortonian) of Rhodes. The third Valvata species concerns V. gregaria also first described from the Istrios Formation of Rhodes. We could not identify the fourth Valvata species, a relatively high and thin-shelled species that somewhat resembles $V$. piscinalis but is less blunt. 


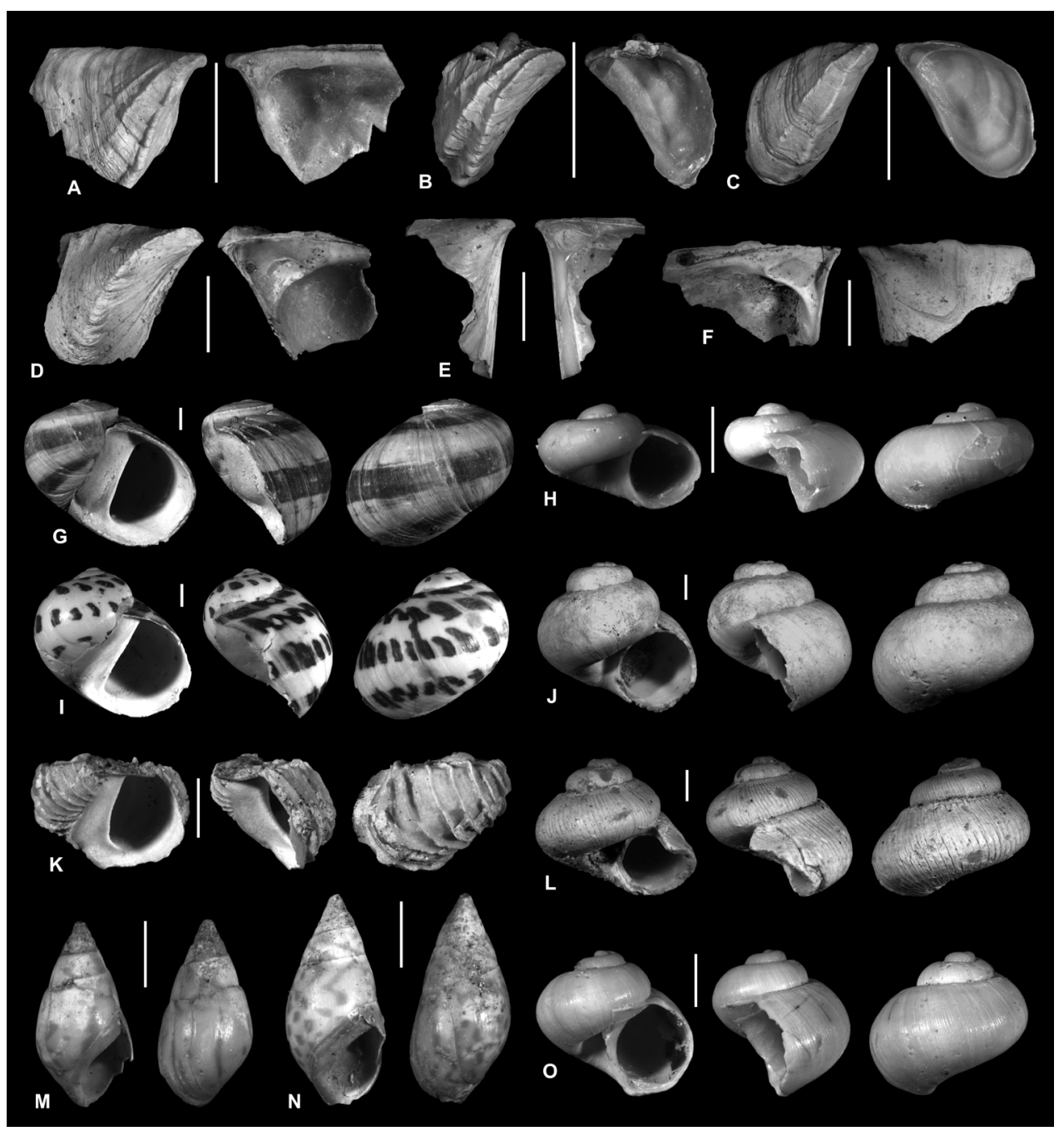

Figure 2.5 Mollusc species from Kolankaya I: A-D. Dreissena kairanderensis. E, F. Dreissena sp. 1. G. Theodoxus percarinatus. H. Valvata gregaria. I. Theodoxus sp. 1. J. Valvata piscinalis. K. Theodoxus sp. 2. L. Valvata skhiadica. M, N. Esperiana cf. bergeroni. O. Valvata sp. Scale bars $=5 \mathrm{~mm}(\mathrm{~A}-\mathrm{F}, \mathrm{M}, \mathrm{N}), 1 \mathrm{~mm}(\mathrm{G}-\mathrm{L}$, O).

The Kolankaya I assemblage also contains eight hydrobiid species (Fig. 2.6). Hydrobiidae sp. 1 and Hydrobiidae sp. 2 have very similar outlines, but Hydrobiidae sp. 2 has slightly irregular sigmoid axial ribs. The convex whorls and deep suture, the somewhat impressed umbilicus and overall shape of both species are reminiscent of Ecrobia, but no confirmed Neogene records of that genus exist for the region and no other species with axial ribbing are known. Together 
with the relatively few different characters in hydrobiid snails, we think the shells could well be evolutionary convergent to Ecrobia. Hydrobiidae s.l. sp. 3 bears some resemblance to Laevicaspia species (such as L. lincta; see Anistratenko, 2008; nomenclature updated after Wesselingh et al., 2019). The fourth species is identified as ?Xestopyrguloides sp. as it reminds of Xestopyrguloides heldreichii (Fuchs, 1877) from the Pliocene of Megara (Greece) as defined by Willmann (1981), but whorls are more aligned and straight-sided in the Turkish material. The fifth species was identified as ?Prososthenia cf. laevigata, which was initially described by Jekelius (1944) from the Pannonian of Soceni, Romania. Our specimen shares the small,

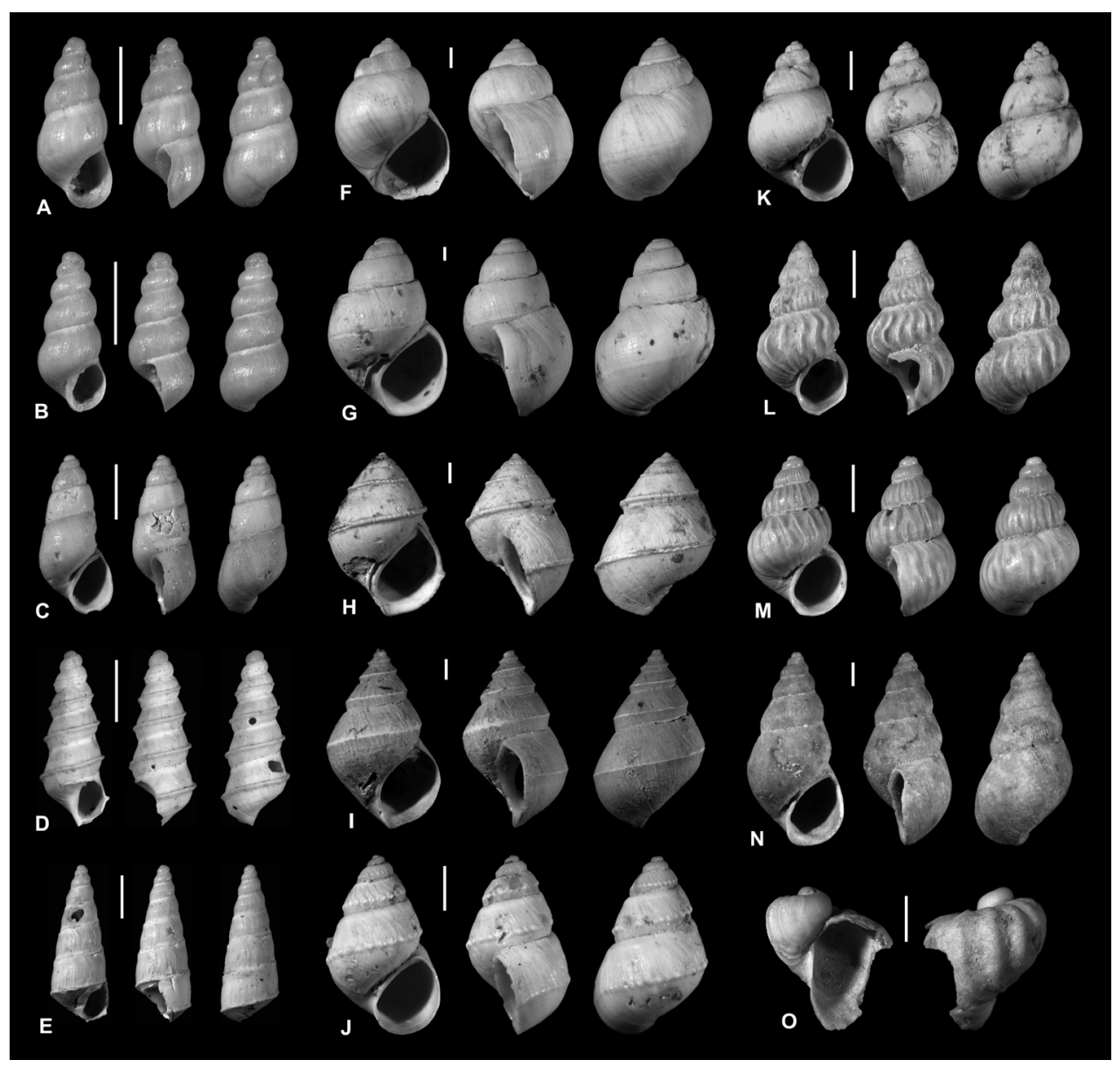

Figure 2.6 Gastropod species from Kolankaya I: ?Graecoanatolica sp. B. ?Iraklimelania sp. C. ?Prososthenia cf. laevigata. D. ?Pyrgula sp. E. ?Xestopyrguloides sp. F. "Staja” lycica. G. "Staja” cf. orientalis. H. "Staja" sp. 1. I, J. “Staja” sp. 2. K. Hydrobiidae sp. 1. L, M. Hydrobiidae sp. 2. N. Hydrobiidae s.l. sp. 3. O. Corymbina cf. elegans. All scale bars $=1 \mathrm{~mm}$. 
slender ovoid shell with ton-shaped last whorl, basal angulation and weakly inclined aperture. The sixth species is tentatively attributed to Graecoanatolica. It is very similar to the species (wrongfully) reported by Wesselingh et al. (2008) from the overlying "Didacna Beds" (= Denizli 2 fauna described below) as G. denizliensis Taner, 1974. The original species described by Taner is a large hydrobiid $(7 \mathrm{~mm})$ with cyrtoconoid spire, moderately convex whorls and thickened aperture. The seventh species was identified as ?Iraklimelania sp. The generic attribution is based on the slender, small shape with a minor but conspicuous constriction below the suture, distinct sigmoidal growth lines, small aperture and a weakly thickened columellar lip, all of which are traits found in Iraklimelania levis from the early Pleistocene of Kos (especially in the paratype illustrated by Willmann, 1981). The smaller size and blunter apex of the Denizli material suggest it is a different, potentially new species. The eighth species is ?Pyrgula sp. has a slender shell with a very strong, blunt, regular keel at $1 / 3$ rd of the whorl height. As with all keeled hydrobiids the attribution to Pyrgula is uncertain.

Four gastropod species were preliminarily attributed to genus Staja. The species are slightly larger than the hydrobiid species described above and more robust. In size (adult specimens are between 0.5 and $1 \mathrm{~cm}$ ) and shape, they are reminiscent to bithyniid snails, yet we have not found any calcite operculum in our material that would indicate the presence of bithyniids. The first species fits well to illustration of Staja lycica (Oppenheim, 1919) originally described from the early Pliocene of Tlos in the Eşen Basin. Our specimens, however, have slightly larger size than the original Staja lycica (ca. 8 vs. $6 \mathrm{~mm}$ ). The second species is attributed to "Staja" orientalis: The small specimens fit well to the species as illustrated by Bukowski (1896), Willmann (1982) and Wesselingh et al. (2008); the larger ones seem just to have one whorl more but otherwise fully correspond. The species was originally described from the Istrios Formation of Rhodes and also recorded from Chios, mainland Greece and Turkey (Harmancik, Denizli). The other two species we preliminarily attribute to Staja show a large variety of morphologies, ranging from slender to bulky, including intermediates. They all share a keel close to the lower suture, which in some individuals is composed of small elongate nodules. We tentatively distinguish two species: a bulky Staja sp. 1 with slightly cyrtoconoid spire, basal keel and distinct fasciole demarcating the umbilicus from the base and a slender Staja sp. 2 with conical (rarely weakly cyrtoconoid) spire with a distinct keel at or slightly below whorl center and without a fasciole.

In our material, we also identified one aquatic pulmonate, i.e. Corymbina elegans (Fig. 2.6), a remarkable axially ribbed lymnaeid genus known from Neogene deposits of Anatolia and the Aegean.

\subsubsection{Mollusc palaeoecology from Kolankaya I}

Two Dreissena species that dominate the faunas of the lower succession show the presence of a hard substrate. Nevertheless, the lack of freshwater indicator groups, such as pearly freshwater mussels and sphaeriid clams, strongly suggest that the fauna lived in anomalohaline 
or strongly alkaline settings. Similarly, within the gastropod faunas several groups that are very abundant in regular freshwater biotopes (streams, rivers, lakes) are notably absent, viz. planorbid and lymnaeid pulmonates (except Corymbina, which occurred in endemic lake faunas). The dominance of prosobranch aquatic gastropods points to lake environments with anomalohaline or alkaline conditions. However, the abundance of I suggests very low salinities as it occurs in rivers and lakes (Glöer, 2019). The Theodoxus species point to clear waters with abundant hard substrate they require to crack their food. Recent Valvata species occur in lakes, rivers, floodplains, springs or ponds, often in eutrophic conditions (Welter-Schultes, 2012). Valvata piscinalis prefers clear, well oxygenated, standing or slowly moving waters and fine grained substrate (Welter-Schultes, 2012). It can tolerate salinities of up to 5 psu (Verbrugge et al., 2012). The dominance of hydrobiids, the frequency of strongly ornamented species in several groups and the lack of common freshwater groups as well as the relatively high species numbers all point to a long-lived lake with slightly elevated salinities during deposition of the Denizli I fauna.

\subsubsection{Mollusc fauna and palaeoecology from Kolankaya II}

The fauna from the upper interval of the section $(640-1415 \mathrm{~m})$ is dominated by Didacna species and has been recorded by Wesselingh et al. (2008) who described the fauna found at the Babadağ BA14 locality (correlates to 1209-1350 m of the studied section) and by Alçiçek et al. (2015) from the Tosunlar outcrop in the northern Denizli Basin. The BA14 fauna consists of four species of Didacna, one Theodoxus species, four hydrobiid species (the abundant and highly variable "Micromelania" phrygica, rare Graecoanatolica, Pyrgula and "Pseudamnicola"), and the spectacularly ribbed Valvata cincta. Within the fauna, low amounts of differentially preserved and reworked freshwater species occur, including Radix cf. ampla, Sphaerium sp. and Pisidium cf. crassisimum. The Tosunlar fauna reported by Alçiçek et al. (2015) is likely younger than that of Babadağ and only contains a single Didacna species. Furthermore, the reworked freshwater component contains Esperiana cf. bergeroni. The mollusc fauna from the Kolankaya II represents mesohaline lake associations with comparably low diversity (11 species) but very high levels of endemicity.

\subsubsection{Ostracod palaeontology}

In total, 32 species belonging to 13 genera were encountered. The ostracods are well preserved and highly abundant but moderate in species numbers.

\subsubsection{Ostracod fauna from Kolankaya I}

The ostracod fauna studied within the $0-66.8 \mathrm{~m}$ and $398-428.5 \mathrm{~m}$ intervals is dominated by leptocytherid ostracods including common Leptocythere sp. 1, Amnicythere multituberculata, A. striatocostata, A. sp. 3, A. sp. 4 and loxoconchid species (Loxoconcha 


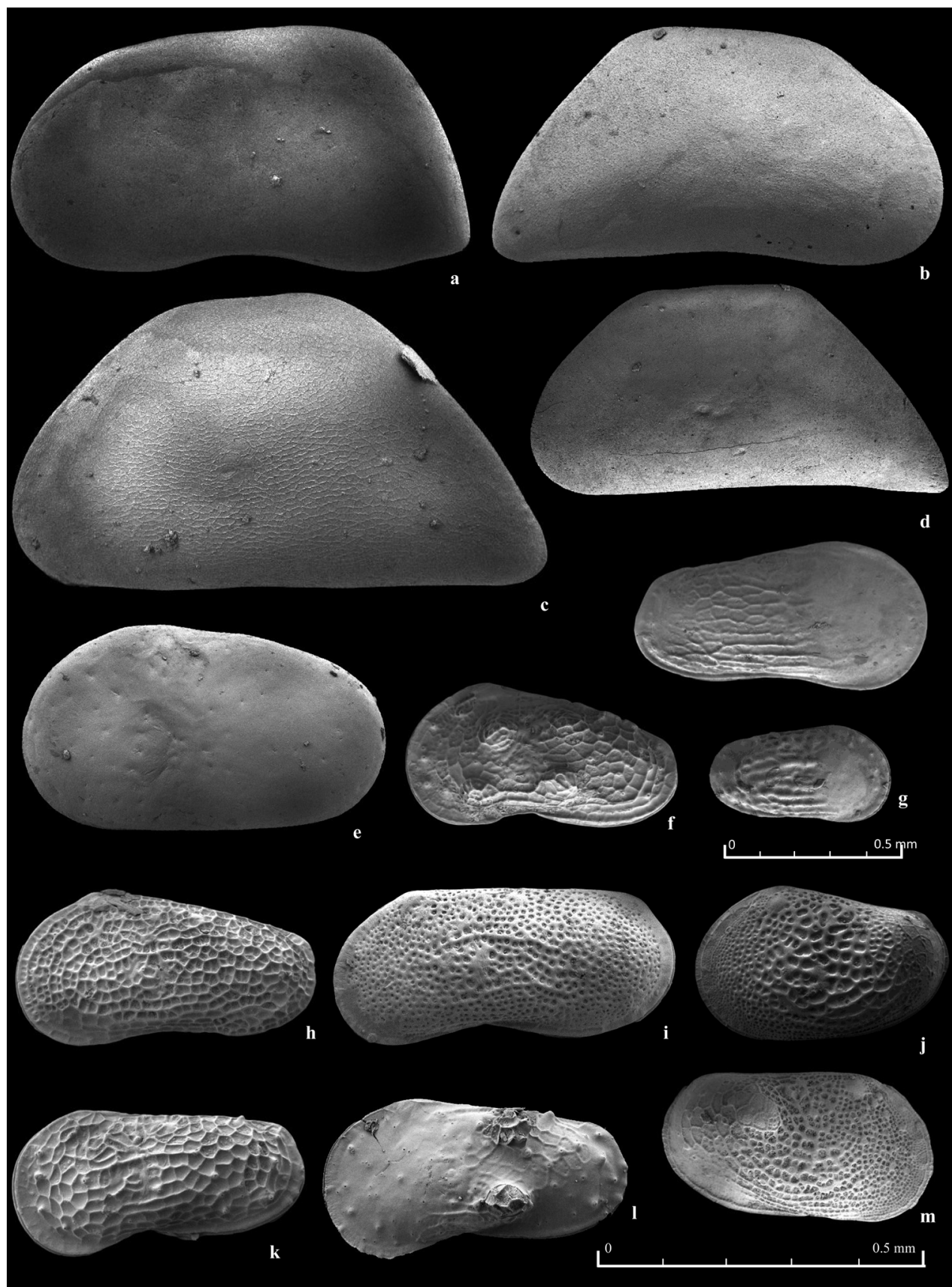


Figure 2.7 (previous page) Most common ostracod species from Kolankaya I. a. Caspiocypris carica, LV, external view; b. Candona ex. gr. angulata, LV, external view; c. Cypria sp., LV, external view; d. Ilyocypris bradyi, RV, external view; e. Ilyocypris gibba, LV, external view; f. Cyprideis ex. gr. torosa, LV, external view; g. Tyrrhenocythere sp., LV, external view; h. Tyrrhenocythere pontica, LV, external view; i. Tyrrhenocythere aff. ruggierii, LV, external view; j. Euxinocythere (Maetocythere) bosqueti, LV, external view; k. Amnicythere sp. 2, external view; 1. Loxoconcha muelleri, LV, external view; m. Loxoconcha ex. gr. eichwaldi, RV, external view; n. Loxoconcha petasa, LV, external view; o. Loxoconcha ex. gr. petasa, RV, external view; p. Loxoconcha ex. gr. petasa spp. 1, LV, external view; q. Loxoconcha ex. gr. petasa spp. 2, RV, extermal view;

babazananica, L. (Loxocaspia) aff. reticulata) as well as some rare occurrences of Cyprideis pannonica, Amnicythere sp. 1 and Tyrrhenocythere aff. pontica (Fig. 2.7). Candonid ostracods are represented by common occurrences of Caspiocypris carica, Candona (Typhlocyprella) sp. together with Typhlocypris fossulata fossulata n. ssp. and Typhlocypris fossulata reticulate n. ssp. The faunal composition indicates oligohaline to lower mesohaline conditions. The presence of both adults and different juvenile stages shows the in situ character of the fauna.

\subsubsection{Ostracod fauna from Kolankaya II}

The lower part of the Kolankaya II (790-799.2 m, 1025-1089.5 m, 1211-1230 m) contains a thin-shelled ostracod fauna with abundant juveniles of candonids, suggesting a freshwater to at most oligohaline environment (Fig. 2.8). The many broken fragments exclude species-level identifications.

The ostracods fauna from the uppermost part of the section (1230-1415 m) has a very distinct composition dominated by candonids (Candona angulata, C. ex. gr. angulata) and loxoconchids (Loxoconcha muelleri, L. eichwaldi) characterising oligohaline - mesohaline conditions (Fig. 2.8). In a few levels, the occurrence of heavily calcified ostracod valves, accompanied by a minor diversification of the assemblage, is indicating a slight increase in alkalinity. These levels contain taxa like Amnicythere sp. 2, Cyprideis torosa, Tyrrhenocythere pontica, Tyrrhenocythere sp., Tyrrhenocythere aff. ruggierii, L. petasa and L. muelleri. From 1253 $\mathrm{m}$, the ostracod valves become commonly thicker and the assemblage is dominated by L. petasa ssp. 1, L. petasa ssp. 2, Euxinocythere (Maeotocythere) bosqueti, Amnicythere sp. 1, A. sp. 2 and C. torosa. Along the succession, rare occurrences of Cypria sp., Candona sp. as well as Ilyocypris bradyi and Ilyocypris gibba suggest the minor influence of a neighbouring freshwater source.

Figure 2.8 (next page) Most common ostracod species from Kolankaya II. a. Candona angulata, LV, external view; b. Candona ex. gr. angulata, LV, external view; c. Cypria sp., LV, external view; d. Ilyocypris bradyi, RV, external view; e. Ilyocypris gibba, LV, external view; f. Cyprideis ex. gr. torosa, LV, external view; g. Tyrrhenocythere sp., LV, external view; h. Tyrrhenocythere pontica, LV, external view; i. Tyrrhenocythere g. Tyrrhenocythere sp., LV, external view; h. Tyrrhenocythere pontica, LV, external view; i. Tyrrhenocythere 


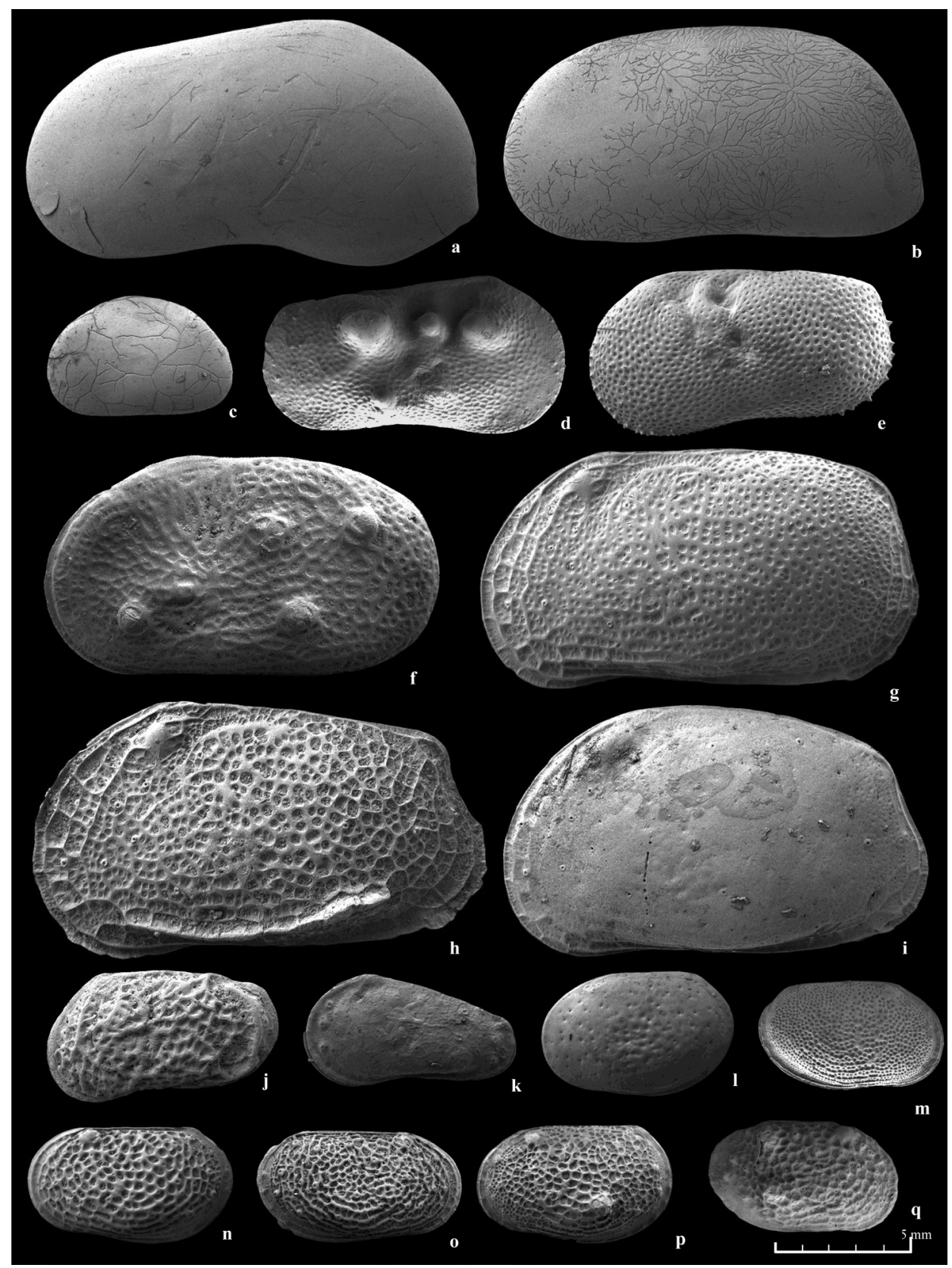

aff. ruggierii, LV, external view; j. Euxinocythere (Maetocythere) bosqueti, LV, external view; k. Amnicythere sp. 2, external view; 1. Loxoconcha muelleri, LV, external view; m. Loxoconcha ex. gr. eichwaldi, RV, external view; n. Loxoconcha petasa, LV, external view; o. Loxoconcha ex. gr. petasa, RV, external view; p. Loxoconcha ex. gr. petasa spp. 1, LV, external view; q. Loxoconcha ex. gr. petasa spp. 2, RV, external view; 


\subsubsection{Palynology and environmental interpretation}

Qualitative results from the palynomorph analyses and their environmental interpretations are reported in Table 2.1. Out of 15 studied samples, six samples did not show any representative palynomorphs or dinocysts that would provide a palaeoenvironmental assessment and these are thus defined as barren. Qualitative assessment of the occurrence of the most indicative palynomorphs is provided here using terms like rare, present, common, abundant.

\begin{tabular}{|c|c|c|c|}
\hline Code & $\begin{array}{c}\text { Str. level, } \\
\text { m }\end{array}$ & Description & Interpretation \\
\hline BD_96 & 1280.6 & $\begin{array}{l}\text { Terrestrial: Pinus (very abundant) } \\
\text { Aquatic: Botryococcus (rare), Achomosphaera (rare). }\end{array}$ & $\begin{array}{l}\text { Mesohaline offshore } \\
\text { environments with } \\
\text { minor freshwater } \\
\text { influence. }\end{array}$ \\
\hline BD_58 & 1261 & $\begin{array}{l}\text { Terrestrial: Pinus (common), plant material (rare). } \\
\text { Aquatic: Botryococcus (abundant), Spiniferites spp. (present, } \\
\text { more abundant than in the previous sample, some S. cruciformis, } \\
\text { some Spiniferites with short spines). }\end{array}$ & $\begin{array}{l}\text { Mesohaline neritic } \\
\text { environments with } \\
\text { freshwater influence. }\end{array}$ \\
\hline DZ_8 & 1088.5 & $\begin{array}{l}\text { Terrestrial: Pinus (abundant), Amarathaceae (reworked), } \\
\text { Poaceae (rare), Abies (rare). } \\
\text { Aquatic: Botryococcus (abundant), Spiniferites (rare, some S. } \\
\text { cruciformis), Impagidinium spongianum (rare), indet. transparent } \\
\text { round palynomorphs }\end{array}$ & $\begin{array}{l}\text { Mesohaline with } \\
\text { significant freshwater } \\
\text { influence }\end{array}$ \\
\hline BDB_35 & 1071 & $\begin{array}{l}\text { Terrestrial: Pinus, Quercus, Asteroideae, Poaceae, } \\
\text { Amaranthaceae. } \\
\text { Aquatic: Botryococcus (very abundant), Pediastrum (very } \\
\text { abundant), dinocysts (common) including Caspidinium rugosum, } \\
\text { Spiniferites (S. bentorii), Achomosphaera spp., Impagidinium } \\
\text { spongianum, cf. Senegalinium, cf. Batiacasphaera. }\end{array}$ & $\begin{array}{l}\text { Mesohaline with } \\
\text { strong freshwater } \\
\text { influence }\end{array}$ \\
\hline CS_11 & 420 & $\begin{array}{l}\text { Terrestrial: Pinus, Quercus, Amaranthaceae, leaf fragments. } \\
\text { Aquatic: Leiosphaeridium, Botryococcus (rare). }\end{array}$ & $\begin{array}{l}\text { Freshwater nearshore } \\
\text { (?) }\end{array}$ \\
\hline CS_2 & 398 & $\begin{array}{l}\text { Terrestrial: Pinus (present), Quercus (rare), Poaceae (rare). } \\
\text { Aquatic: Spiniferites (abundant), Achomosphaera (abundant), } \\
\text { Polysphaeridium zoharyi (common), Lingulodinium } \\
\text { machaerophorum (common), Botryococcus (occasional). }\end{array}$ & $\begin{array}{l}\text { Meso- to euryhaline, } \\
\text { coastal/lagoonal }\end{array}$ \\
\hline DZB_5 & 32.2 & $\begin{array}{l}\text { Terrestrial: abundant pollen and plant material, likely reworked } \\
\text { Aquatic: Botryococcus (abundant), Spiniferites cruciformis (rare). }\end{array}$ & $\begin{array}{l}\text { Oligo- to mesohaline, } \\
\text { near-shore }\end{array}$ \\
\hline DZZ_5 & 21 & $\begin{array}{l}\text { Terrestrial: Pinus (abundant), Poaceae (abundant), Quercus } \\
\text { (rare), Lactucoideae (rare), Cupressaceae (rare), plant detritus, } \\
\text { fungal spores. } \\
\text { Aquatic: cf. Senegalinium (rare), Pterospermella (rare). }\end{array}$ & $\begin{array}{l}\text { Oligo- to mesohaline, } \\
\text { near-shore }\end{array}$ \\
\hline DZZ_1 & 1 & $\begin{array}{l}\text { Terrestrial: } \text { Pinus (abundant), Abie (rare), Poaceae (occasional). } \\
\text { Aquatic: Achomosphaera (abundant), cf. Galeacysta etrusca } \\
\text { (occasional), Impagidinium, cf. Pyxidinopsis }\end{array}$ & $\begin{array}{l}\text { Meso- to euryhaline, } \\
\text { offshore }\end{array}$ \\
\hline
\end{tabular}

Table 2.1 Qualitative analysis of terrestrial (pollen) and aquatic (dinocysts, algae and acritarch) palynomorphs and from selected stratigraphic intervals of the Babadağ -1 section. 


\subsubsection{Strontium Isotope geochemistry}

The strontium isotope $\left({ }^{87} \mathrm{Sr} /{ }^{86} \mathrm{Sr}\right)$ ratios measured on ostracod valves range from 0.7081 to 0.7082 (Table 2). The lack of major variations in the acquired values suggests that the water source of the basin was persistent within the studied section.

\begin{tabular}{|c|c|c|c|}
\hline Sample code & Strat. level, $\mathbf{m}$ & ${ }^{87} \mathrm{Sr} /{ }^{86} \mathrm{Sr}$ ratio & Table $2.2^{87} \mathrm{Sr} /{ }^{86} \mathrm{Sr}$ ratios in selected stratigraphic \\
\hline BD23 & 1243 & 0.708145 & \\
\hline BD104 & 1233.5 & 0.708104 & intervals of the Babadad-1 section. \\
\hline CS14 & 423 & 0.708231 & \\
\hline CS8 & 413.5 & 0.708087 & \\
\hline CS2 & 398 & 0.708092 & \\
\hline DZZ6 & 25 & 0.708182 & \\
\hline
\end{tabular}

\subsection{Discussion}

\subsubsection{Age and correlation to GPTS}

The age of Kolankaya Formation was previously estimated as late Miocene - late Pliocene (Yalçınlar, 1983; Saraç, 2003; Doğan et al., 2020). The base of the Kolankaya Formation contains a small mammal fauna attributed to the MN 11-12 (Kiranyer, Acıdere, Güzelpınar and Gölyerilocalities, late Tortonian - early Messinian) (Yalçınlar, 1983; Doğan et al., 2020). The Kolankaya Formation is unconformably overlain by the Tosunlar Formation, whose base contains a MN 17 - MNQ 18 mammal fauna (Early Pleistocene) (Kaymakci, 2006). The studied Babadağ section is dominated by reversed polarity (R1-R5) delimited by normal zones (N1, N2) (Fig. 2.4). Within the late Miocene - late Pliocene, the two longest reversed chrons are C3r (6.033-5.235 Ma) and C2Ar (4.187-3.596 Ma). On the assumption that we did not miss any short normal polarity interval in our Babadağ section, we think these two chrons are the most likely to correlate to the Babadağ section (Hilgen et al., 2012).

The mollusc and ostracod content of the studied section displays a high level of endemism that hampers their use in age assessments. The presence of the dinocyst Galeacysta etrusca found in sample DZZ 1 at the base of the section represents interesting biostratigraphic elements, as it has a well-dated biogeographic history. Galeacysta etrusca is a Paratethyan dinocyst that originates from Lake Pannon and its appearance in the Eastern Paratethys serves as a marker of the Pontian stage dated at 6.1 Ma (Grothe et al., 2014). During the Lago Mare phase of the MSC (5.3-5.4 Ma), Galeacysta etrusca invaded the Mediterranean (Popescu et al., 2009; Grothe et al., 2018). This coincides with the upper C3r chron. Hence, we correlate the lower normal zone $\mathrm{N} 1$ in the Babadağ section to the top of chron C3An.1n, the reversed intervals R1-R5 to the long reversed chron C3r, and the upper normal zone N2 to the C3n.4n (Fig. 2.9). These results in averaged sedimentation rates of $1.54 \mathrm{~m} / \mathrm{kyr}$ for the long reversed interval. The base of the Babadağ section is several meters below the C3An.1n-C3r boundary which is dated to $\sim 6.03 \mathrm{Ma}$. Extrapolation of the $\mathrm{C} 3 \mathrm{r}$ sedimentation rates upon the C3n.4n 
chron results in an age of $\sim 5.13 \mathrm{Ma}$ for the top of the section, which should, in any case, be older than 4.997 Ma (top of C3An.1n).
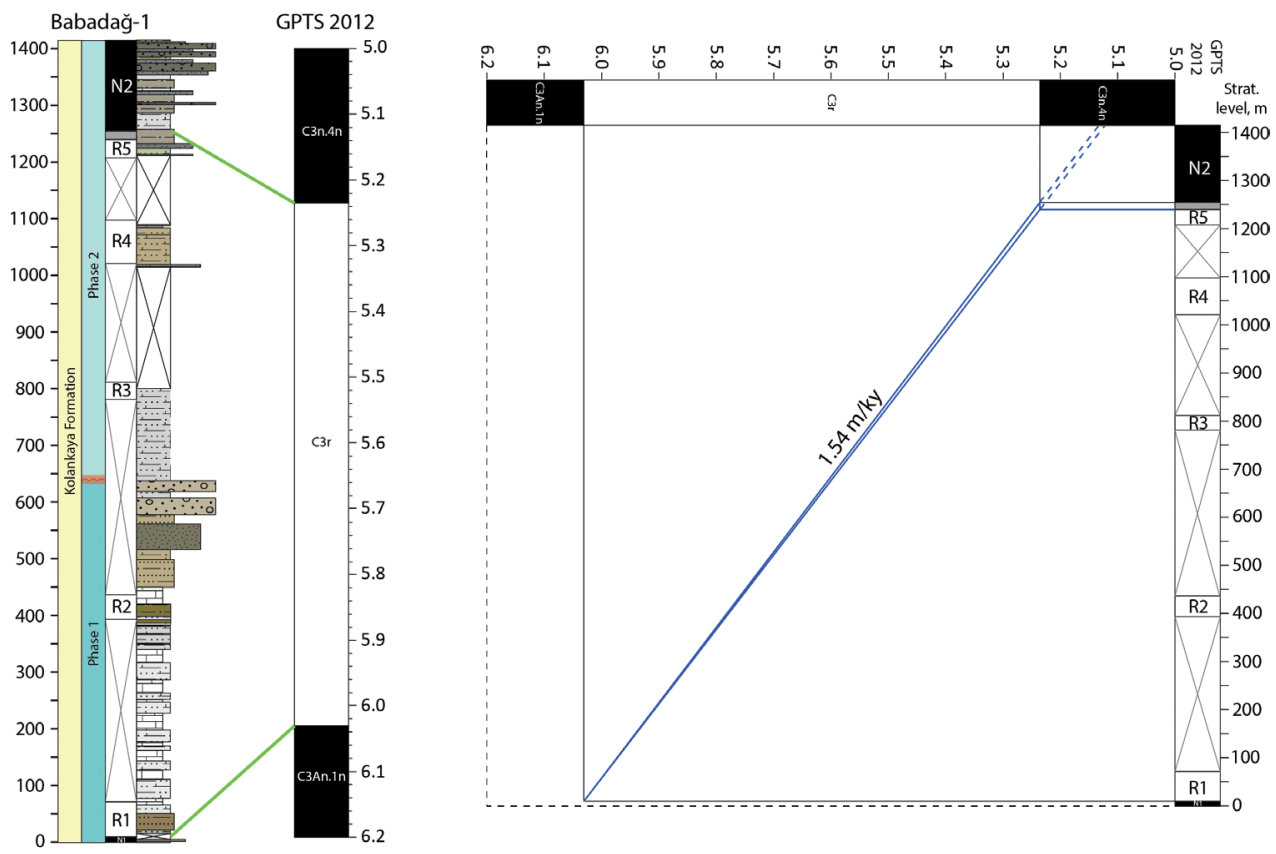

Figure 2.9 Correlation of the polarity patterns from the Babadağ-1 section to the GPTS and the sedimentation rate curve.

\subsubsection{Biogeographic signature of the Denizli biota}

The biogeographic signature of the molluscs in Kolankaya II is very different from that of Kolankaya II (Fig. 2.10). An almost complete faunal turnover was found between both mollusc faunas. A comparable change is also seen in the ostracod faunas, but the biogeographic signature of the latter did not change significantly. On the other hand, the composition and biogeographic signature of the dinocyst assemblage shows no significant differences between the lower and upper assemblages.

The Kolankaya I mollusc fauna represents the cross-road between the Paratethys region and the Graeco-Anatolian province (sensu Neubauer et al., 2015), as well as between Miocene and Quaternary type faunas. Typical late Neogene-Quaternary Graeco-Anatolian taxa are Corymbina, "Staja", ?Iraklimelania, ?Graecoanatolica, Valvata gregaria and V. skhiadica. Some species (Theodoxus percarinatus, T. sp. 1, T. sp. 2, Dreissena kairanderensis and probably several of the unidentified hydrobiids) may be endemic to the Denizli Basin. Some similarities or close relationships exist with taxa from the late Miocene and Pliocene Paratethyan faunas from the 


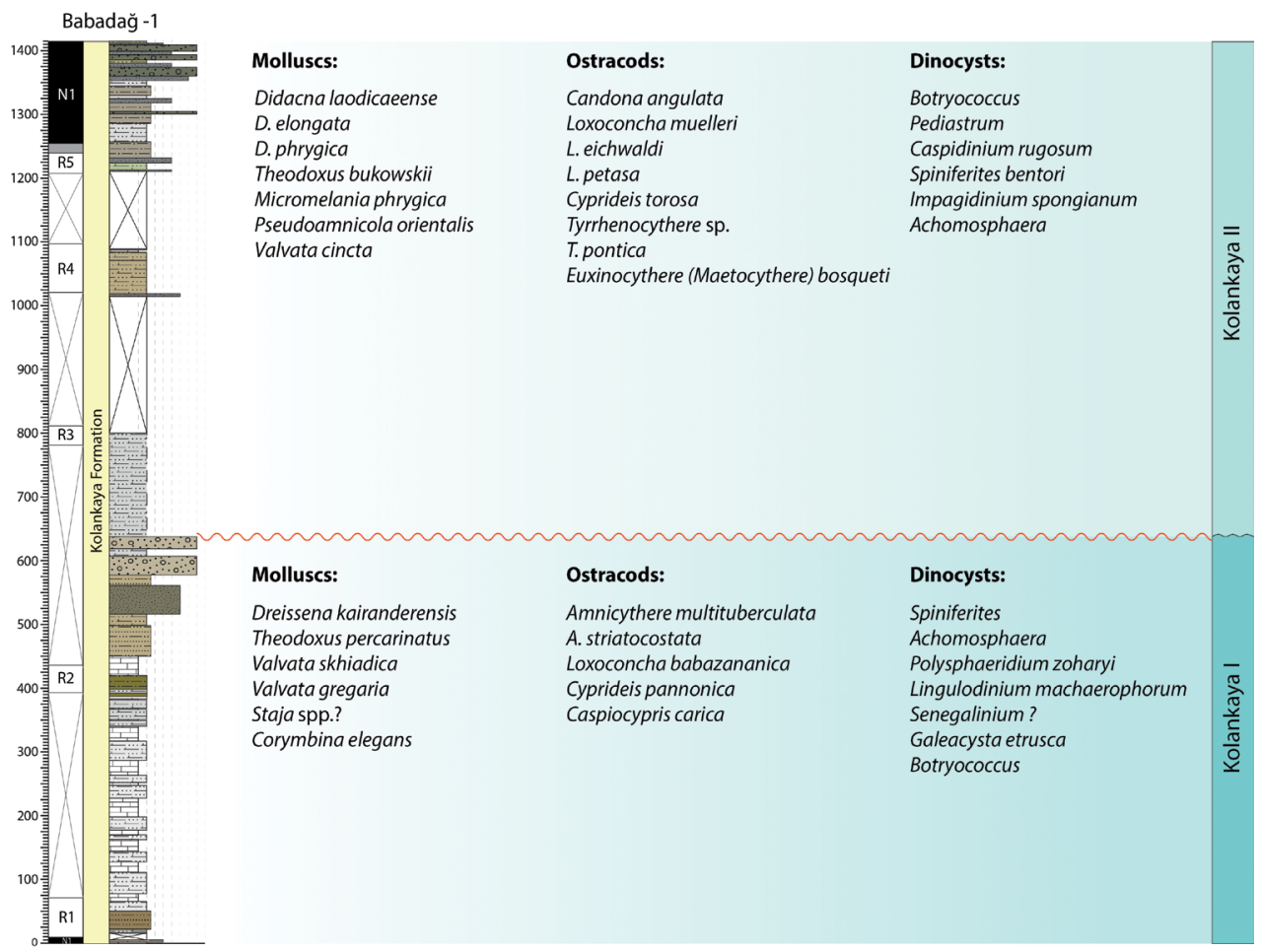

Figure 2.10 Characteristic mollusc, ostracod and dinocyst faunas (including algae) from the lower (Kolankaya-I) and upper (Kolankaya-II) parts of the Babadağ-1 section.

Pannonian and Dacian basins. These include Dreissena sp. 1/D. rostriformis s.l., Theodoxus sp. 2/T. pilidei and Esperiana cf. bergeroni.

The Kolankaya-II mollusc fauna, characterized by the abundance of Didacna and the similarities between the abundant "Micromelania" phrygica and some species of Laevicaspia, shows a distinct Pontocaspian character of the fauna (Wesselingh et al., 2008).

The Denizli ostracod assemblage contains common Pannonian to Pontian (late Miocene) species of the Pannonian Basin (Jiřiček, 1985), the Dacian Basin (Olteanu, 1989; Stoica et al., 2013; van Baak et al., 2015b; Lazarev et al., 2020) and the Euxinian Basin (Tunoglu and Ünal, 2001; Matzke-Karasz and Witt, 2005). The common occurring genus Typhlocypris (T. fossulata fossulata n. ssp., T. fossulata. reticulate n. ssp.) and Candona (Typhlocyprella) sp. are Paratethyan brackish water ostracods known from the upper Pannonian of the Vienna Basin (Krstić, 1972; Sokač, 1972), Pontian of Turkey Tunoğlu (2003) and many other Paratethyan localities (Carbonnel, 1969; Vekua, 1975; Freels, 1980; Pipík and Bodergat, 2007). Another dominant genus Amnicythere originated in the middle Miocene (Sarmatian) from restricted marine environments inside the Paratethys. It diversified progressively in Lake Pannon and colonized 
the Eastern Paratethys during the Maeotian and Pontian (Gliozzi et al., 2005; Namiotko et al., 2012).

The Denizli dinocyst and aquatic palynomorph assemblages contain taxa with oceanic, Paratethyan and freshwater origins. Caspidinium rugosum, Spiniferites cruciformis, Galeacysta etrusca and Impagidinium spongianum are typical Paratethyan dinocysts, which evolved in brackish environments during the late Miocene (e.g. Sütö-Szentai, 2000). Impagidinium spongianum (as well as various species previously described as Pontiadinium) was observed in Miocene sediments of the Pannonian Basin with inferred low salinities (Sütö-Szentai, 1982; Soliman and Riding, 2017). Pyxidinopsis psilata and Spiniferites cruciformis are both present in Pontian age sediments from the Black Sea and the Caspian Sea (Grothe et al., 2018; Richards et al., 2018b), suggesting a Paratethyan origin for the species. Finally, Galeacysta etrusca is a Central Paratethyan species (Magyar et al., 1999). 1999), that migrated into the Eastern Paratethys (at 6.1 Ma) and Mediterranean (5.3-5.4 Ma) and whose occurrence may serve as an excellent regional age indicator (Grothe et al., 2018). Lingulodinium macherophorum, Spiniferites spp. and Achomosphaera spp. can be found in different aquatic environments, and have a with wide tolerances for salinity (Zonneveld et al., 2013; Mudie et al., 2017). However, both Spiniferites and Achomosphaera genera contain endemic Paratethyan species (such as $S$. cruciformis, S. hennersdorfensis and A. brevis) (Soliman and Riding, 2017). Lingulodinium machaerophorum occurs in the present-day Black Sea and Caspian Sea (Mudie et al., 2017). It has been recorded from intervals representing the basal Pontian marine flooding event ( 6.1 Ma) in both the Black Sea Basin (Grothe, 2016) and the Caspian Sea Basin (Richards, 2018a). Polysphaeridium zoharyi is a typical euryhaline species, which can be found in coastal and lagoonal subtropical to tropical regions in the present day, and may also be related with high productivity (Zonneveld et al., 2013). Pediastrum and Botryococcus are both green algae that typically grow in freshwater environments (although some species may tolerate oligohaline to low mesohaline salinities). However, they can also be carried a distance into basins by rivers, so they may also be deposited in saline water at some distance from a river mouth.

\subsubsection{Mechanisms and potential pathways of Paratethyan faunal migrations throughout the region}

The biogeographic history of the mollusc fauna from the Kolankaya I reveals a link with the Graeco-Anatolian region, while the Kolankaya II molluscs has characteristic Paratethyan/ Pontocaspian affinities. The ostracods and dinocysts from the entire section are predominantly of Central and Eastern Paratethyan origin. The occurrence of these groups in the Denizli Basin implies an existence of a late Miocene connection with the neighbouring Eastern Paratethys. Palaeogeographic reconstructions (Lüttig and Steffens, 1975) show that the TortonianMessinian depositional record of west Anatolia consists of lacustrine and fluvial facies shaping a dense network of semi-connected lacustrine basins (Fig. 2.11). Despite uncertain 
chronostratigraphy and size of these basins, their role in the regional biogeography and interbasinal connectivity history may be strongly underestimated.

The Anatolian region has previously been considered as hosting a late Miocene Paratethyan - Mediterranean connection (e.g. Van Baak et al., 2018). A major pathway could have run through the north Aegean-Black Sea region (Option 1, Fig. 2.11). This represents the most lucid region to host the Anatolian-Paratethyan gateway, even though the interbasinal areas have mostly been eroded due to recent uplift. Another potential connection (Option 2, Fig. 2.11) would require a connection with the Caspian Sea running through entire Turkey. This option seems to be less realistic as no wide-spread lacustrine systems are known from Central or Eastern Anatolia (Fig. 2.11). Eastwards, only the Tabriz Basin in northern Iran was interpreted to be connected with the Caspian Sea via the Araks River Valley (Reichenbacher et al., 2011). The palaeogeographic reconstruction also indicates that in southern Anatolia, a potential gateway with the Mediterranean could exist (Option 3, Fig. 2.11). A direct connection between the Mediterranean Basin and the Anatolian Lake System would generally require an influx of marine Mediterranean faunas, which are not present in our sections. This requirement, however, is not necessary if a connection only persisted during Lago Mare times, when the Mediterranean was colonized by Paratethyan faunal groups. The presence of some Lago Mare affiliated ostracods and absence of Lago Mare molluscs in our record suggests that if a connection via Option 3 existed, it would be strongly restricted either physically due to gateway size or ecologically due to differences in salinity.

Despite faunal and palaeogeographic preconditions, the acquired Sr isotope-ratios from our record strongly contradicts any significant open interbasinal connections. Comparison of values with those from the Eastern Paratethys (Grothe et al., 2020) and the Mediterranean (Roveri et al., 2014b) shows that the Denizli values are much lower and most likely represent a local water source (Fig. 2.12). The sampling resolution, however, was rather low and we cannot exclude that we may have missed some very rapid and short influxes of Paratethyan waters.

Besides faunal migration through gateways, avian dispersal may offer an alternative explanation. Dispersal via migratory waterbirds has been shown to be a common mechanism shaping species distributions of invertebrates in both fossil (Wesselingh et al., 1999; Haase, M., Naser, M.D. \& Wilke, T., 2010; Büyükmeriç and Wesselingh, 2018) and recent records (Kappes and Haase, 2012; van Leeuwen et al., 2012a; van Leeuwen et al., 2012b). However, avian dispersal may contribute to the appearance of selected species outside their native range but unlikely accounts for the occurrence of entire assemblages.

The Kolankaya I fauna is present already at the base of the section and perhaps does not reflect the first occurrence in the Denizli Basin. The Kolankaya II fauna with characteristic Pontocaspian Didacna molluscs first occurs a couple of hundred meters above the Kolankaya I/Kolankaya II contact (Wesselingh et al., 2008), the contact interval itself being hindered by poorly-exposed section. Thus, it remains still unclear, whether the faunas of Kolankaya I and 


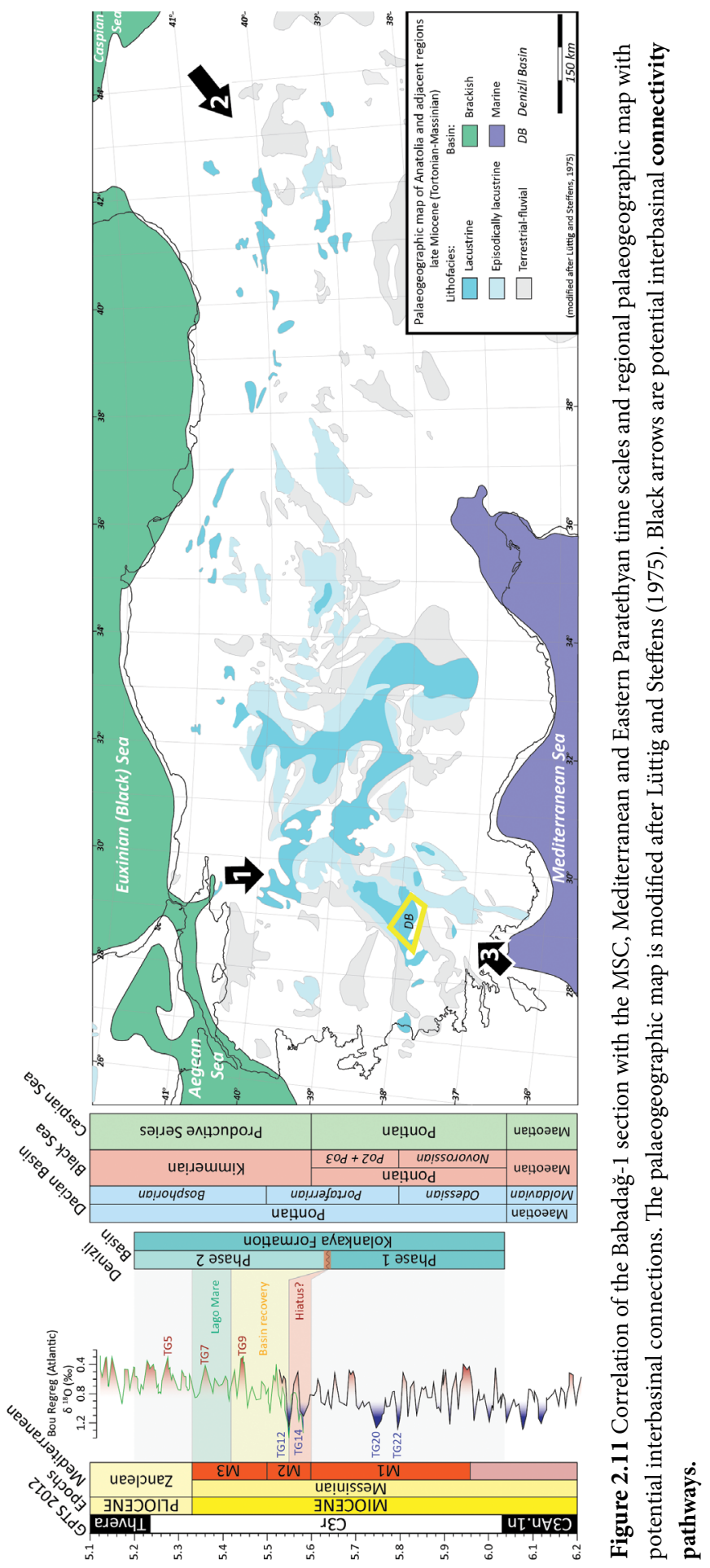




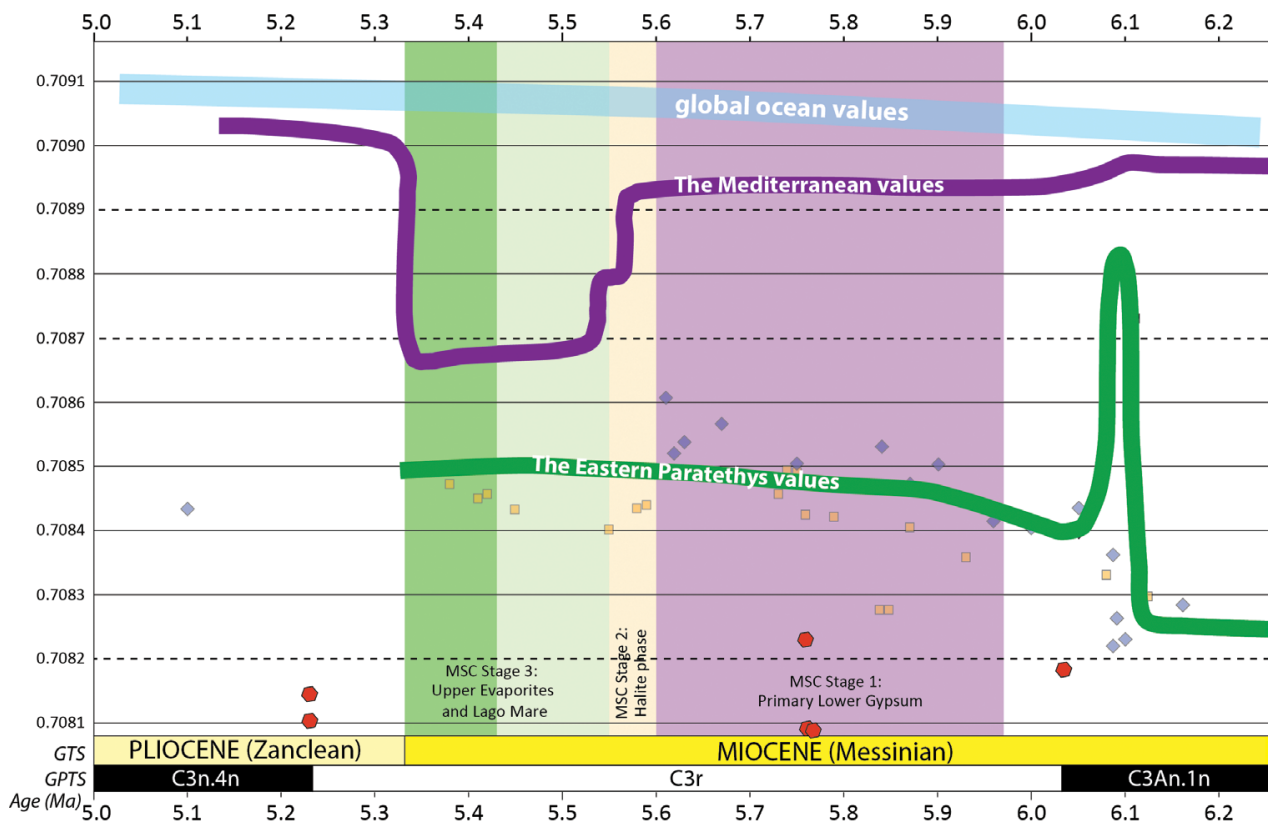

Figure 2.12 Strontium $\left({ }^{87} \mathrm{Sr} /{ }^{86} \mathrm{Sr}\right)$ isotope values from the Babadağ- 1 section (red dots) and their comparison with values from the global ocean, Mediterranean (Roveri et al., 2014b) and Eastern Paratethys (Grothe, 2016). MSC - Messinian Salinity Crisis. Figure is modified after Grothe, 2016.

II entered the Denizli Basin in a single event through an Anatolian-Paratethyan connection. Nevertheless, the Denizli Basin functioned as a satellite basin for Paratethyan biota. The arrival and establishment of both Graeco-Anatolian and Paratethyan elements must have contributed to the rise of the Anatolian aquatic biodiversity hotspot.

\subsubsection{Palaeoenvironmental evolution of the Denizli Basin at the Mio-Pliocene transition}

Our multiproxy data show that the studied section in the Denizli Basin covers the $\sim 6.0$ 5.1 Ma time interval, during which the basin was occupied by an oligohaline - mesohaline lake. A significant palaeoenvironmental reorganisation took place around $\sim 5.6 \mathrm{Ma}$ when a complete faunal turnover took place. There are several tectonic and climatic processes that may have contributed to the abrupt Kolankaya I/II transition, which may be revealed by the lithological changes in the boundary interval. The lower succession Kolankaya I is dominated by white marlstones (Fig. 2.1) that are interpreted as distal lake deposits (e.g. Alçiçek, 2007b; FA 1 in Chapter 3). The marlstones become abruptly replaced by a 1-2 m-thick mud-clast breccia (450 m, Fig. 2.2C) that passes upwards into a thick, coarse siltstone-sandstone-conglomerate succession (up to $675 \mathrm{~m}$, Fig. 2.2B, 2.2D). The conglomerate package at the Kolankaya I/II boundary consists of two individual beds separated by marlstone and can be traced across the 
basin for several kilometres. This lithological trend indicates a significant base level drop and regression of the lake, which hints to major aridification of the region.

The mud-clast breccia indicates an erosion of lacustrine marlstone and the following siltstone-sandstone packages strongly represent a prograding delta system. The extrapolation of sediment accumulation rates results in ages of $\sim 5.75 \mathrm{Ma}$ for the mud-clast breccia and 5.6 $\mathrm{Ma}$ for the base of the upper conglomerate package. These ages suggest a correlation in time of Kolankaya I with MSC Stage 1 (5.97-5.6 Ma) and Kolankaya II with MSC Stage 2 (5.6-5.55 Ma), MSC Stage 3 (5.55-5.33 Ma) and the early Zanclean (Fig. 2.11) that characterize the onset, culmination, aftermath and end of the MSC in the Mediterranean (Roveri et al., 2014a). The late Miocene climate aridification that took place in concert with the MSC may have caused a decrease in regional precipitation in Anatolia. The base-level drop in our record suggests that the Denizli Basin and potentially the entire Anatolian Lake System reacted to the MSC. Unfortunately, the palaeoprecipitation data from the Anatolian region are still very scarce, and any regional comparison is hampering.

Recovery of the lake started with the onset of the Kolankaya II succession and was potentially linked to a late Messinian climate rebound and a rise of precipitation in Anatolia at 5.6 Ma. The Kolankaya II succession is dominated by lacustrine marlstones and prodeltaic siltstones that become abruptly replaced by incised conglomerates bodies in the upper part of the section. The latter ones are interpreted as sublacustrine channel fans likely related to tectonic uplift pulses of the Menderes Massif (Chapter 3). The base of the Kolankaya II succession contains no representative molluscs (only rare shell debris) and a poorly preserved ostracod fauna. The Paratethyan/Pontocaspian fauna assemblage with characteristic Didacna first appears in the interval $775-800 \mathrm{~m}$ dated at $\sim 5.5 \mathrm{Ma}$ and becomes abundant in interval $1210-1415 \mathrm{~m}$ dated at $\sim 5.25-5.13 \mathrm{Ma}$.

The rise of the Paratethyan water level at 5.6 Ma and its overspill into the Mediterranean could have also affected the Anatolian Lake System. The above-proposed Option 1 gateway would very well fit this scenario. During this time interval, the Caspian Sea experienced isolation and strong base-level drop (Productive Series), making Option 2 untenable (van Baak et al., 2017). The Kolankaya II fauna after its blossom at around 5.25 Ma survived in the basin but gradually degraded until the Early Pleistocene where the last and only Didacna species was found as described in the Tosunlar location (Alçiçek et al., 2015).

\subsection{Conclusion}

Our study shows that in the latest Miocene, the Denizli Basin acted as a sink for Paratethyan and continental aquatic groups. Once arriving in the basin, several groups underwent further radiations, forming highly endemic faunas. The integrated magneto-biostratigraphic, geochemical and palaeontological data bring new insights into the late Miocene palaeoenvironmental history and biogeographic evolution of SW Anatolia. 
- The 1415 m lacustrine succession of the Kolankaya Formation in the Denizli Basin is dated between 6.0-5.1 Ma and consists of two coarsening-upwards successions with different ostracod and mollusc faunas.

- The lower Kolankaya I succession represent an oligo- to mesohaline lake with characteristic Paratethyan dinocysts, ostracods and molluscs as well as some endemic GraecoAnatolian mollusc groups.

- The occurrence of the dinocyst Galeacysta etrusca that has a well-reconstructed Paratethyan biogeographic history suggests that the Denizli Basin was physically connected to the Pontian domain.

- The lithological coarsening trend in the upper part of Kolankaya I succession between 5.75-5.6 Ma characterizes progradation of alluvial fans in response to a significant lake level drop.

- The Kolankaya I/II faunal turnover coincides with the peak (Stage 2) of the Messinian Salinity Crisis and for the first time shows the impact of this event on the biogeography of SW Anatolia.

- Lacustrine marlstones mark the onset of the upper Kolankaya II succession and characterize recovery of the lake at 5.6 Ma.

- The lower part of the Kolankaya II succession (between $~ 5.6-5.38 \mathrm{Ma}$ ) contains fragile remnants of Didacna molluscs and a poorly preserved ostracod fauna. This faunal assemblage becomes highly abundant between $\sim 5.25-5.13 \mathrm{Ma}$.

- The Sr isotope-ratios of Kolankaya I and II are similar, indicating local rivers as the main water source for the Miocene Denizli Basin.

- The interbasinal connection between Anatolian lakes and the Eastern Paratethys is still speculative as no actual gateways have been yet discovered.

\subsection{Acknowledgements}

Our research is part of the PRIDE project (Pontocaspian Rise and Demise), which is funded by European Union's Horizon 2020 research and innovation program, under the Marie Skłodowska-Curie Action (grant agreement № 642973). 


\section{DEPOSITIONAL ARCHITECTURE AND DRIVERS OF SUBLACUSTRINE CHANNEL-FANS IN THE EXTENSIONAL DENIZLi BASIN (EARLY Zanclean, SW Anatolia).}

In preparation:

Lazarev, S., Rausch, L., Abels, H.A., Alçiçek, M.C., Wesselingh, Stoica, M., van Baak, C.G.C., Krijgsman, W., 2020. Depositional architecture and drivers of sublacustrine channel-fans in the extensional Denizli Basin (early Zanclean, SW Anatolia). 


\section{Abstract}

Turbidite systems delivered by sediment-gravity flow to deep parts of lacustrine basins form a complex channel-levee-fan architecture that has a high reservoir potential. The deep-water fans also serve as an excellent palaeoenvironmental archive for basin level trends and climatic and tectonic processes in the catchment area. Despite a good theoretical understanding of the evolution of sublacustrine deepwater systems, actual outcrops that reveal the $4 \mathrm{D}$ evolution of the system are rare. Moreover, there is not much known about the reaction of ecosystems to the progradation of sublacustrine channel fans. Here, we present a 185-m thick and 900-m wide depositional record of the upper Kolankaya Formation of the Denizli Basin (early Zanclean, SW Anatolia). The studied section displays extensive lacustrine packages, locally interrupted by incised conglomerate bodies. The integration of high-resolution facies analysis with studies of ostracod fauna and mollusc taphonomy facilitates the reconstruction of the depositional architecture and evolution of sublacustrine channel-fan systems. The sedimentary succession has been subdivided in 4 facies associations: lacustrine (FA1), distal fan (FA2), sublacustrine channel-levee (FA3) and proximal fan with distributary channels (FA4). The lacustrine FA1 contains in situ and reworked assemblages with Didacna molluscs, while the others comprise mostly reworked nearshore assemblages with Micromelania, Theodoxus and Didacna species. The fauna reworking was mostly triggered by slumping within FA 1 and FA 2, turbidity currents in FA 3 and debris flows in FA4. The ostracod fauna is dominated by oligo-, mesohaline genera Loxoconcha, Amnicythere, Candona, Cyprideis and Maetocythere. The transverse sublacustrine channel-fans of the Denizli Basin are oriented perpendicular to the basin-bounding Babadağ Fault zone that acted as the growth fault in response to the uplift of the Menderes Massif. The characteristic increase of the conglomerate-prone debris flows chronologically coincides with a regional precipitation increase during the latest Messinian-early Zanclean transition. Our multidisciplinary study provides new insights into the architecture and evolution of sublacustrine channel-fan systems in extensional basins and their impact on the basin ecosystems. It will also serve as an analogue for future sedimentological studies in geodynamically similar basins around the world.

\subsection{Introduction}

Deep-water fans are turbidite systems with a complex sedimentary architecture formed by sediment-gravity-flows at the termini of land-deep sea sediment-routing systems (Menard, 1955; Covault, 2011). These systems provide the most substantial amount of detrital material from shallow marine/lake and continental settings to deeper parts of basins and have a great reservoir potential (Pettingill and Weimer, 2002; Covault, 2011). Deep-water fans are known from both marine/oceanic basins and lake basins. Despite being formed in various geodynamic settings, both, submarine and sublacustrine systems reveal common architectural elements: feeding channel, fan lobes, well-developed network of distributary channels bounded by levees. 
Fan lobes are classified as upper (proximal), middle or lower (distal) depending on the distance from the major sediment discharge point (Nichols, 2009). The architecture of deep-water fans is controlled by a wide range of allogenic (climate, tectonism) and autogenic (fan lob switching) drivers whose particular role may vary significantly (Clark and Pickering, 1996). Some of the deepwater systems evolved in response to climatically-driven base level drops (Soreghan et al., 1999; Covault, 2011), while others developed from tectonically-uplifted basin margins (Soreghan et al., 1999; Gawthorpe and Leeder, 2000; Nichols, 2009; Sümer et al., 2012). Due to their distal position in the basin, deepwater channel-fans better preserve tectonic and climatic signals, which are commonly removed by erosion on the basin margins. Therefore, facies analysis of deepwater fan-systems may provide essential insights into the palaeogeographic evolution of the basin and surrounding areas.

In this paper, we document and investigate the depositional architecture of sublacustrine fan deposits from the late Miocene-early Pliocene Kolankaya Formation of the Denizli Basin, SW Anatolia (Turkey), a graben type basin that formed within the Aegean - west Anatolian extensional province. The Kolankaya $\mathrm{Fm}$ is dominated by lake marls that are frequently and abruptly interrupted by channelised conglomerate-sandstone bodies. The depositional evolution is actively controlled by very active normal faults related to exhumation of the metamorphic Menderes massif (Seyitoğlu and Işık, 2015) that occurred between 15 and 5 Ma (van Hinsbergen, 2010a). At the time, the Denizli Basin was mostly isolated, yet faunal evidence for some exchange with adjacent basins and even the Paratethyan realm. Here, we integrate high-resolution facies analysis, analysis of ostracod fauna and mollusc taphonomy in a $185 \mathrm{~m}$-thick succession in order to reconstruct the evolution of depositional environments and biotic response. The great lateral and vertical exposures allow tracing and documenting lateral variability, stacking parameters and higher rank architecture of sublacustrine channelfan systems.

The aims of this paper are to (1) make a detailed integrated stratigraphic-taphonomic documentation of sublacustrine fans, (2) investigate the palaeoenvironmental context of fan development and (3) identify drivers of fan evolution in the Denizli Basin during the Miocene-Pliocene transition. This study will help to improve understanding of the response of hydrologically-sensitive Anatolian lakes to major palaeoenvironmental rearrangements during the late Neogene and to improve insights into drivers of deepwater sublacustrine fan evolution in general.

\subsection{Geological setting}

\subsubsection{Tectonic evolution of the Denizli Basin}

The Denizli Basin is a WNW-ESE-trending graben located in the SE portion of the Menderes Massif (Fig. 3.1). The basin is $50 \mathrm{~km}$ wide and $70 \mathrm{~km}$ long. Its southern margin 
is limited by the Babadag fault zone with steep $\left(45-50^{\circ}\right)$ north-dipping normal faults (Westaway, 1993). In its north-western part, the Denizli Basin passes into two other grabentype basins segregated by the Central Menderes Massif: the northern Alaşehir Basin and the southern Büyük Menderes Basin. The Neogene structural evolution of the Denizli graben was inextricably linked with the exhumation of the adjacent metamorphic Menderes Massif that formed in response to extension in the Aegean - west Anatolian region related to roll-back of the Aegean slab (Veen et al., 2009; van Hinsbergen, 2010a; Seyitoğlu and Işık, 2015). The latter initiated c. $25 \mathrm{Ma}$ ago (van Hinsbergen, 2010a). The earliest infill of the Denizli Basin and adjacent Alaşehir and Büyük Menderes basins occurred during the Burdigalian ( 16-18 $\mathrm{Ma}$ ) reflecting the amplification of regional extension. At the same time, the Menderes Massif became compartmentalised into a northern (NMM), central (CMM) and southern (SMM) part (van Hinsbergen, 2010a). Subsequent exhumation of the CMM amplified around $~ 5 \mathrm{Ma}$ ago (post-Miocene) and was accompanied by the formation of detachment and brittle faults along the surrounding basin margins (Çemen et al., 2006; Çiftçi and Bozkurt, 2009; Veen et al., 2009; Seyitoğlu and Işık, 2015). One of the most active fault zones - the Babadağ fault zone, along the SSW margin of the Denizli Basin was controlling the depositional processes throughout basin history (Westaway, 1993) and is active nowadays (Alçiçek et al., 2013).

\subsubsection{Late Miocene-Pliocene regional palaeogeography}

During the Neogene, southwestern Anatolia was located between the Eastern Paratethys in the north and the Mediterranean basins in the south (Fig. 3.1). The Mio-Pliocene transition (Messinian-Zanclean) in the region was a time of dramatic palaeoenvironmental changes linked to regional tectonic and global climatic rearrangements. In the latest Tortonian, starting at 7.5 Ma, well-pronounced aridification and enhanced seasonality provoked restructuring of terrestrial biotic communities world-wide (Herbert et al., 2016) and has also been documented in Paratethyan and Mediterranean realms (Tzanova et al., 2015; Vasiliev et al., 2019a; Vasiliev et al., 2019b). At $\sim 5.6 \mathrm{Ma}$, glacio-eustatic restriction of the Gibraltar gateway (Krijgsman et al., 2018) triggered isolation of the Mediterranean, resulting in a strong Mediterranean base level drop as a response to the disruption of the oceanic water budget. This event forms the peak of the Messinian Salinity Crisis (MSC), and is expressed by deposition of kilometrethick evaporite successions on the Mediterranean seafloor (MSC Stage 2, sensu Roveri et al., 2014a). The Eastern Paratethys underwent only minor base-level changes during the MSC. An estimated maximum drop of $\sim 50 \mathrm{~m}$ occurred at $5.6 \mathrm{Ma}$ in concert with the Mediterranean fall (Krijgsman et al., 2010; van Baak et al., 2017). During the final MSC phase (Stage 3 sensu Roveri et al., 2014a), the Paratethys overspilled into the Mediterranean transforming the latter into an anomalohaline lake with characteristic Paratethyan biota present to the Malaga Basin in southern Spain (Stoica et al., 2016; Grothe et al., 2018). This so-called Lago Mare phase persisted until the marine flooding at the beginning of Pliocene (Zanclean flood: $5.33 \mathrm{Ma}$ ) 

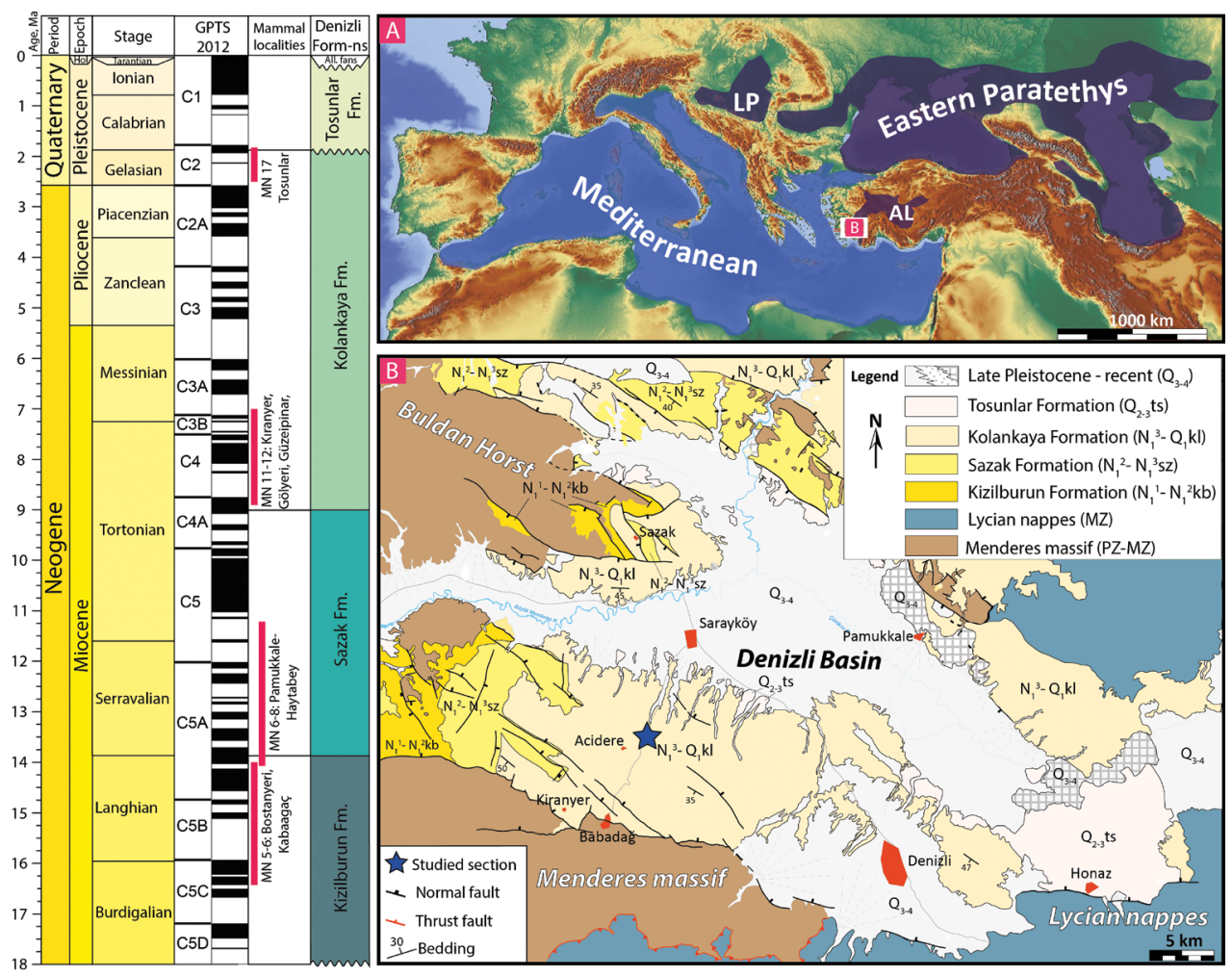

Figure 3.1 Regional lithostratigraphic formations and mammal localities of the Denizli Basin in the Global time scale (GTS). Location of the studied section: A. In the Paratethyan region; B. In the Denizli Basin. Regional time scale and geological map are modified after (Sun, 1990). The GTS is based on Hilgen et al., 2012. The palaeogeograpic map was build using the outlines of Popov, 2004. Abbreviations used: Fm. - Formation, AL - Anatolian Lake System, LP - Lake Pannon.

wiped these faunas out and the modern Mediterranean and its marine faunas established (Hsü et al., 1973; Micallef et al., 2018).

The faunas from the Neogene succession of the Denizli Basin imply phases of isolation and episodic connectivity with the Paratethyan realm (Alçiçek et al., 2015; Wesselingh et al., 2008). A recent study documents the presence of two faunistically distinct lake phases in the late Miocene-Pliocene Kolankaya Formation between 6.0 and 5.2 Ma (Chapter 2) (Rausch et al., 2020). The lower Kolankaya I lake phase contains Paratethyan ostracod faunas, and the upper Kolankaya II lake phase contains a mixed Paratethyan-Pontocaspian fauna. The studied sections in this paper are located in the Kolankaya II lake phase. 


\subsubsection{Regional stratigraphy}

The Neogene succession of the Denizli Basin is subdivided into four lithological formations: the Kizılburun (late Burdigalian-late Langhian), Sazak (early Serravallian-early Tortonian), Kolankaya (late Tortonian-Piacenzian) and Tosunlar (Gelasian) Formations that are wellexposed along the basin margins (Fig. 3.1) (Şimşek, 1984; Saraç, 2003; Kaymakci, 2006; Alçiçek et al., 2015). The sections studied here are part of the Kolankaya Formation.

The Kolankaya Formation has a maximum thickness of $500 \mathrm{~m}$ and consists of 4 units: 1) Laminated marlstones and siltstones; 2) Alternations of marlstones, claystones and sandstones with abundant invertebrate fauna; 3) Alternations of well-sorted massive, planar and currentripple cross-bedded sandstones and planar cross-stratified conglomerates with invertebrate fauna; 4) Alternations of poorly sorted cross-stratified conglomerates, sandstones and marlstones (Alçiçek et al., 2007a). The section presented herein belongs to the upper part of Unit 2 and the lower part of Unit 3.

Preliminary small mammal age constraints indicate a late Miocene age for this formation (Alçiçek et al., 2015). Recent magnetostratigraphic analyses of the Kolankaya Formation performed throughout units $1-3$ showed a long $(1230 \mathrm{~m})$ reversed polarity zone at the base and a shorter $(160 \mathrm{~m})$ normal polarity zone at the top that were correlated to C3r - C3n.4n (6.04$5.23 \mathrm{Ma}$ ) (Chapter 2). According to this age model, Unit 1 has a late Messinian age ( 6.0-5.6), Unit 2 covers the latest Messinian to earliest Zanclean (5.6-5.2 Ma) and Unit 3 is early Zanclean and younger $(<5.2 \mathrm{Ma})$.

\subsection{Methodology}

The studied succession is $185 \mathrm{~m}$ thick (Fig. 3.2), located in the SW portion of the Denizli Basin and exposed in the Babadağ valley on the east side of the Babadağ-Saraykoy road (Fig. 3.1, GPS $\left.37^{\circ} 51^{\prime} 46.06^{\prime \prime} \mathrm{N} 28^{\circ} 53^{\prime} 34.52^{\prime \prime} \mathrm{E}\right)$. The section has been logged for sedimentological and taphonomical analyses and sampled for ostracod and mollusc fauna as well as for magnetostratigraphy (Chapter 2). For the sedimentological study and sampling, a series of 0.2 to $1 \mathrm{~m}$ deep trenches were excavated in the outcrop to expose fresh bedrocks. The section was stratigraphically measured with Jacob's staff and logged at a centimetre scale (Fig. 3.2). During the logging, lithology, grain size, rock colours using a Munsell colour book, sedimentary structures (using Tucker, 2011), bounding surfaces and fossil content and preservation were carefully described. The beds were also traced laterally and photographed to capture spatial distribution.

Taxonomic identifications of molluscs (following Wesselingh et al., 2008) and taphonomy of their shells were described in the field. Taphonomic features such as (dis-)articulation, fragmentation, dissolution and distribution (orientation and density) were documented.

For the ostracod study, 64 samples of 300-500 g sediments were taken throughout the section from fine-grained, freshly excavated intervals (Fig. 3.2). Samples have been washed and 


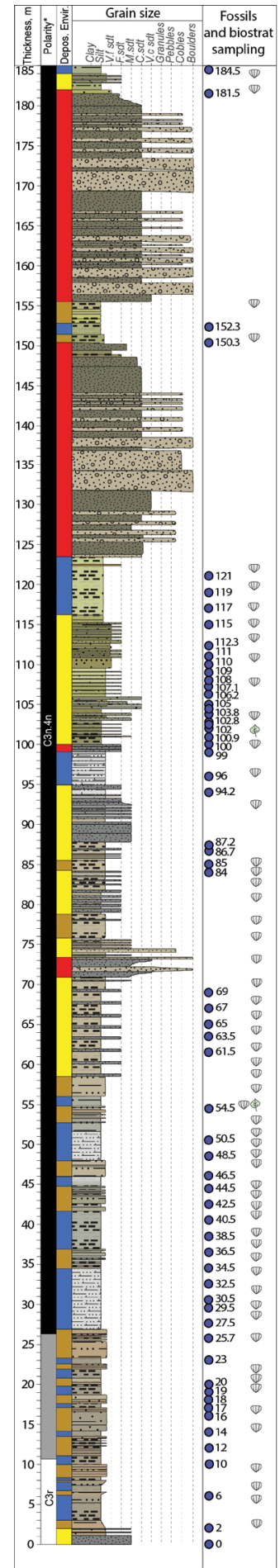

Legend:

FA1 - Lacustrine

FA2 - Distal fan

$\square$ FA3-Levee

FA4 - Proximal fan/Distributary channels

- Ostracod samples

(1) Leaf imprints

(1) Molluses

Grain size

\begin{tabular}{|l|c|}
\hline Clay & $<4 \mu \mathrm{m}$ \\
\hline Silt & $4-63 \mu \mathrm{m}$ \\
\hline Very fine-grained sandstone & $63-125 \mu \mathrm{m}$ \\
\hline Fine-grained sandstone & $125-250 \mu \mathrm{m}$ \\
\hline Medium-grained sandstone & $250-500 \mu \mathrm{m}$ \\
\hline Coarse-grained sandstone & $500 \mu \mathrm{m}-1 \mathrm{~mm}$ \\
\hline Very coarse-grained sandstone & $1-2 \mathrm{~mm}$ \\
\hline Granules & $2-4 \mathrm{~mm}$ \\
\hline Pebbles & $4-64 \mathrm{~mm}$ \\
\hline Coubles & $64-256 \mathrm{~mm}$ \\
\hline Boulders & $>256 \mathrm{~mm}$ \\
\hline
\end{tabular}

Figure 3.2 Lithological log of the studied section. Columns (from left to right): Stratigraphic thickness (in meters), magnetic polarity (Chapter 2), Facies associations, lithological column with grain size and sampling column with ostracod sampling points and distribution of fossil molluscs. 
sieved over $63 \mu \mathrm{m}$, and the dried residue was handpicked using a ZEISS - GSZ light microscope. Identification of ostracod fauna was performed using the taxonomic concept previously published by Moore (1961) and Van Morkhoven (1962). Furthermore, information on the taxonomy provided in the work of Livental (1929), Agalarova (1967), Yassini (1986), Krstić (1973), Olteanu (1989) and Rausch (2020) was taken into account.

\subsection{Results}

\subsubsection{Lithological facies}

In total, eleven lithological facies have been documented in the studied section (Table 3.1). Based on the mutual occurrence of facies and the geometry of lithological units, four facies associations (FA) have been determined.

\begin{tabular}{|c|c|c|c|c|}
\hline Lithofacies & $\begin{array}{c}\text { Sedimentary structure } \\
\text { and thickness }\end{array}$ & Occurence & Interpretation & Fig. \\
\hline $\begin{array}{l}\text { Mh } \\
\text {-Laminated } \\
\text { marsltone }\end{array}$ & $\begin{array}{l}\text { White }(2.5 Y 8 / 2) \text {, pale yellow }(5 Y \\
8 / 2 ; 2.5 Y 8 / 3) \text { parallel-laminated } \\
(10-50 \mathrm{~mm}) \text { to thinly parallel- } \\
\text { laminated }(1-4 \mathrm{~mm}) \text { marlstone. }\end{array}$ & $\begin{array}{l}\text { Associated with } \\
\text { Fh, Sm locally } \\
\text { interbedded with } \\
\text { Sr, Sh. }\end{array}$ & $\begin{array}{l}\text { Suspension fallout in the } \\
\text { standing water column, seasonal } \\
\text { control on the colouring of } \\
\text { laminae (Dean and Fouch, } \\
\text { 1983a) }\end{array}$ & $3.3 A$ \\
\hline $\begin{array}{l}\text { Fh - } \\
\text { Laminated } \\
\text { siltstone }\end{array}$ & $\begin{array}{l}\text { Pale yellow }(5 Y \text { 8/3), very pale } \\
\text { brown (10YR 8/3), light grey (10Y } \\
\text { 7) parallel-laminated (to thinly- } \\
\text { parallel laminated ( } 1-3 \mathrm{~mm}) \\
\text { siltstone, locally sandy. }\end{array}$ & Associated with Sm. & $\begin{array}{l}\text { Small scale low-density turbidity } \\
\text { flows }\end{array}$ & $3.3 B$ \\
\hline $\begin{array}{l}\text { Sm - } \\
\text { Massive } \\
\text { sandstone }\end{array}$ & $\begin{array}{l}\text { Structureless, fine- to coarse- } \\
\text { grained sandstone with } \\
\text { non-erosive to erosive, flat to } \\
\text { undulating bases. Locally, with } \\
\text { dispersed pebbles or mud clasts. }\end{array}$ & $\begin{array}{l}\text { Associated with Mh, } \\
\text { Fh, Sp, Gcm, Gmm. }\end{array}$ & $\begin{array}{l}\text { Massive accumulation from } \\
\text { sediment-laden turbidity flows. }\end{array}$ & $3.3 C$ \\
\hline $\begin{array}{l}\text { Sh - } \\
\text { Laminated } \\
\text { sandstone }\end{array}$ & $\begin{array}{l}\text { Parallel-laminated fine to } \\
\text { medium-grained well-sorted } \\
\text { sandstone with flat slightly } \\
\text { erosive to non-erosive bases. }\end{array}$ & $\begin{array}{l}\text { Associated with Sm, } \\
\text { vertically grades into } \\
\text { Sr, St and Sp, locally } \\
\text { occurs within Mh. }\end{array}$ & $\begin{array}{l}\text { Lower and upper stage flow } \\
\text { regime in fluvial channels (Miall, } \\
\text { 1996; Vincent et al., 2010) }\end{array}$ & $3.3 D$ \\
\hline $\begin{array}{l}\text { Sp - Planar } \\
\text { cross- } \\
\text { laminated } \\
\text { sandstone }\end{array}$ & $\begin{array}{l}\text { Planar cross-laminated fine-to } \\
\text { coarse-grained sandstone. }\end{array}$ & $\begin{array}{l}\text { Associated with Sh, } \\
\text { Sm. }\end{array}$ & $\begin{array}{l}\text { Migration of linguoidal bedforms } \\
\text { (Miall, 1996). }\end{array}$ & $3.3 D$ \\
\hline $\begin{array}{l}\text { Sr - Ripple } \\
\text { cross- } \\
\text { laminated } \\
\text { sandstone }\end{array}$ & $\begin{array}{l}\text { Uni-directional current rippled } \\
\text { and cross-laminated fine-grained } \\
\text { sandstone with asymmetrical } \\
\text { ripples. Ripple amplitudes of } \\
2-3 \mathrm{~cm} \text {. }\end{array}$ & Associated with Fh. & $\begin{array}{l}\text { Migration of uni-directional } \\
\text { current ripples in fluvial channels } \\
\text { and overbank (levee) deposits. }\end{array}$ & $3.3 E$ \\
\hline $\begin{array}{l}\text { St - Trough } \\
\text { cross- } \\
\text { laminated } \\
\text { sandstone }\end{array}$ & $\begin{array}{l}\text { Trough cross-laminated fine to } \\
\text { medium-grained sandstone. } \\
\text { Trough cross-sets are up to } 4 \mathrm{~cm} \\
\text { thick. }\end{array}$ & $\begin{array}{l}\text { Associated with Fh, } \\
\text { Sm. }\end{array}$ & $\begin{array}{l}\text { Migration of sinuous-crested } \\
\text { dunes in fluvial channels (Miall, } \\
\text { 1996; Vincent et al., 2010). }\end{array}$ & $3.3 F$ \\
\hline
\end{tabular}




\begin{tabular}{|c|c|c|c|}
\hline $\begin{array}{l}\text { Gcm - Clast } \\
\text { supported } \\
\text { massive } \\
\text { gravel }\end{array}$ & $\begin{array}{l}\text { Unsorted conglomerate with } \\
\text { pebbles and blocks form } 2 \mathrm{~cm} \text { to } \\
50 \mathrm{~cm} \text {, locally up to } 1.5 \mathrm{~m} \text {. The } \\
\text { base is erosive, irregular. }\end{array}$ & $\begin{array}{l}\text { Associated with Sh, } \\
\text { Sm. }\end{array}$ & $\begin{array}{l}\text { Pseudoplastic debris flow, inertial 3.3G } \\
\text { bedload, turbulent flow (Miall, } \\
\text { 1996). }\end{array}$ \\
\hline $\begin{array}{l}\text { Gmm - } \\
\text { Matrix } \\
\text { supported } \\
\text { massive } \\
\text { gravel }\end{array}$ & $\begin{array}{l}\text { Unsorted conglomerate with } \\
\text { pebbles and cobbles up to } 20 \\
\mathrm{~cm} \text { big and medium to coarse- } \\
\text { grained sandy matrix, locally } \\
\text { contains abundant bivalve shells. } \\
\text { The base is erosive, irregular. }\end{array}$ & $\begin{array}{l}\text { Associated with Sm, } \\
\text { Ggm. }\end{array}$ & $\begin{array}{l}\text { High-strength, viscous, plastic } \\
\text { debris flow (Miall, 1996). }\end{array}$ \\
\hline $\begin{array}{l}\text { Gmt - } \\
\text { Matrix } \\
\text { supported } \\
\text { stratified } \\
\text { gravel }\end{array}$ & $\begin{array}{l}\text { Moderately sorted, normal } \\
\text { graded trough cross-stratified } \\
\text { sandstone. }\end{array}$ & Associated with $\mathrm{Gcm}$. & $\begin{array}{l}\text { Branching of debris flows and } \\
\text { minor channel infill (Miall, 1996). }\end{array}$ \\
\hline $\begin{array}{l}\text { Ggm - } \\
\text { Breccia of } \\
\text { mud clasts }\end{array}$ & $\begin{array}{l}\text { Well rounded to sub-rounded } \\
\text { mud clasts, from } 2 \text { to } 20 \mathrm{~cm} \text { size } \\
\text { in coarse-grained poorly-sorted } \\
\text { sandstone matrix. The base is } \\
\text { erosive, flat. }\end{array}$ & $\begin{array}{l}\text { Associated with } \\
\text { Gmm and Sm, } \\
\text { incised into Mh with } \\
\text { erosional contact. }\end{array}$ & $\begin{array}{l}\text { Erosion of the underlying } \\
\text { sediments by bottom-hugging } \\
\text { currents within fluvial channels. } \\
\text { Intraformational origin. }\end{array}$ \\
\hline
\end{tabular}

Table 3.1 Lithological facies interpretations within the studied section, their sedimentological

characteristic and relations. The colour codes are from Munsell colour book, and facies codes are modified after Miall (1996).

\subsubsection{Facies associations and their faunal content}

\subsubsection{Facies association 1 - Lacustrine}

Facies association 1 (FA1) is represented by alternations of $<0.5$-m thick beds of thinly (1-4 $\mathrm{mm}$ ) parallel-laminated and convoluted marlstones (Figs. 3.4A, 3.5). Thin-parallel-lamination displays interchange of darker and lighter laminae, which are often disturbed by lenses, streaks and single ripples of fine-grained mica sandstone ( $\mathrm{Sm}, \mathrm{Sr}$ ) (Fig. 3.3A). The convoluted beds lack sedimentary structures and are limited below and above by thinly-laminated beds with irregular contacts. The marlstone beds are frequently separated by $1-3 \mathrm{~cm}$ sheet-like beds of massive fine-grained mica sandstone. The FA1 forms packages of $0.5-7 \mathrm{~m}$ and gradually passes into FA2 or FA3 or with sharp, irregular contact into FA4.

Figure 3.3 (next page) Photos of lithological facies summarised in Table 3.1. Scale: hammerhead - 15 $\mathrm{cm}$ long, scale bars are in $\mathrm{cm}$ division. A. Parallel-laminated marlstone (Mh); B. Parallel-laminated siltstone (Fh); C. Massive sandstone (Sm); D. Parallel-laminated and planar cross-laminates sandstone (Sh and Sp); E. Ripple cross-laminated sandstone ( $\mathrm{Sr}$ ) among thin marlstone-siltstone alternation; $\mathrm{F}$. Trough cross-laminated sandstone (St); G. Unsorted clast-supported conglomerate (Gcm); H. Unsorted matrix-supported conglomerate (Gmm); I. Moderately sorted, trough cross-stratified matrix-supported conglomerate (Gmt); J. Breccia of mud clasts (Ggm). 

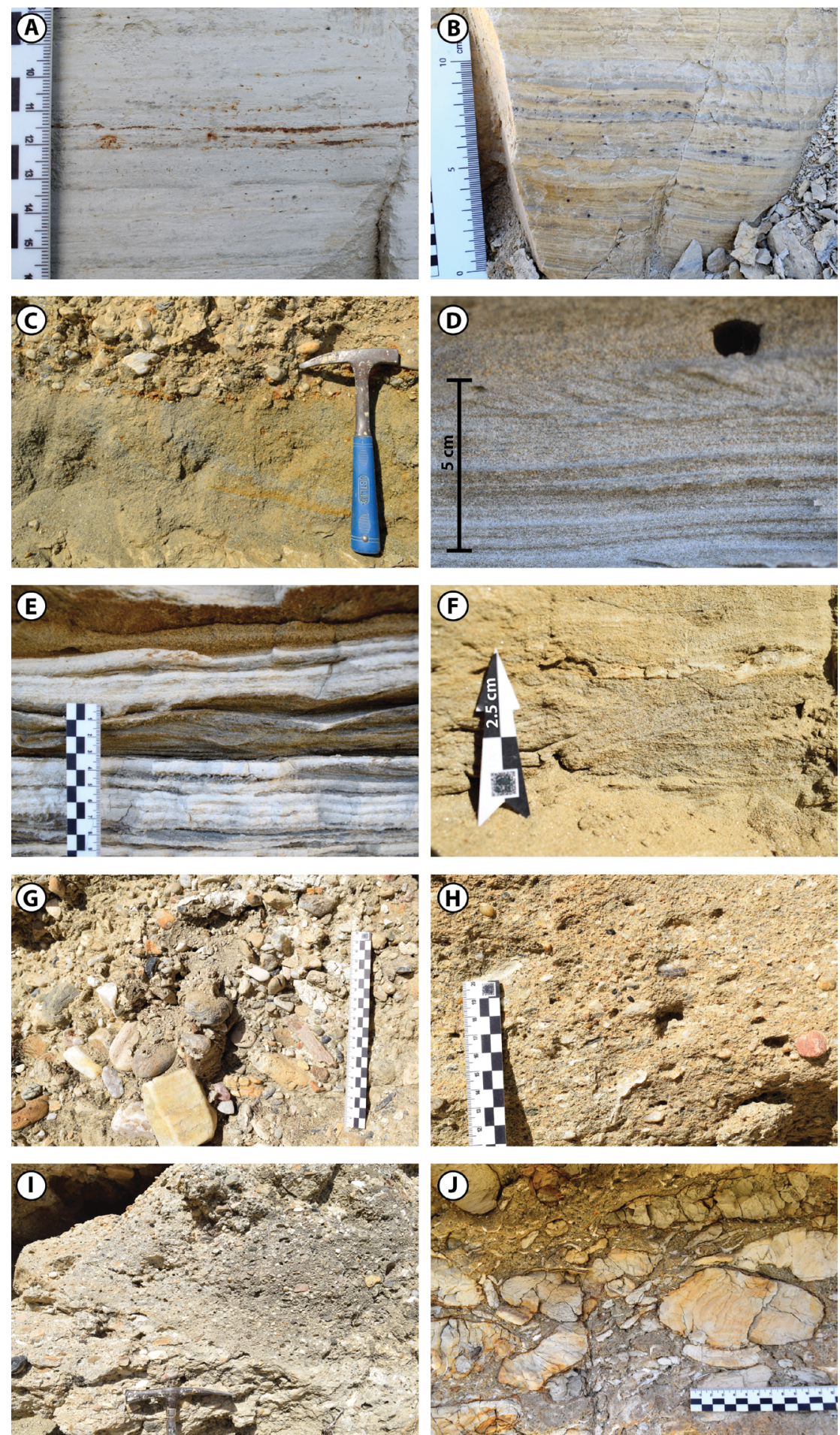

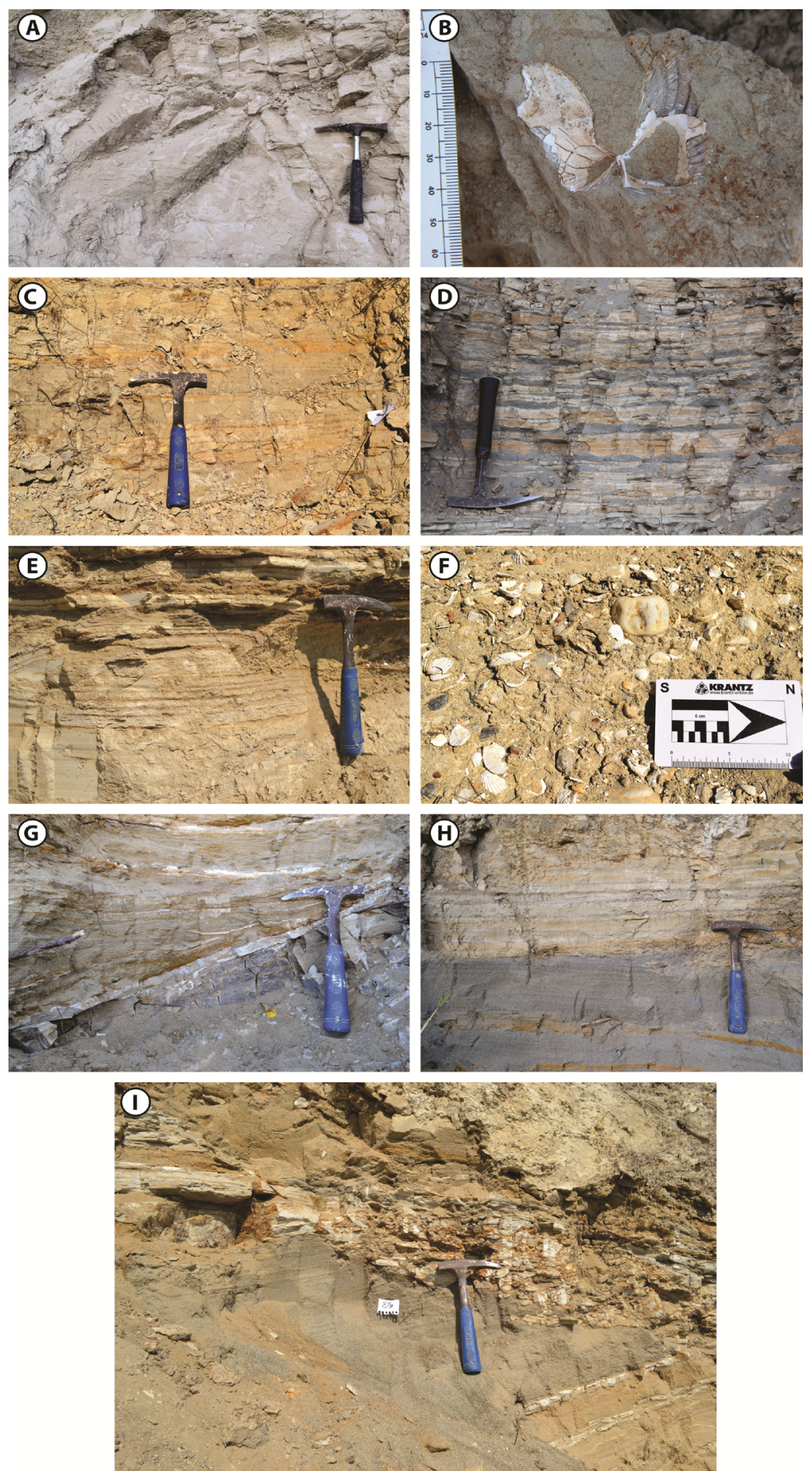
Figure 3.4 (previous page). Field photos of facies associations and sedimentary features. Scales are similar to Fig. 3.3. A. Facies association 1 - Lacustrine; B. Didacna pair the FA 1 (lacustrine); C. Facies association 2 - Distal sublacustrine fan; D. Facies association 3 - Sublacustrine channel levee; 4. Slump in unstable marlstone blanket formed on top of attenuated channel; F. Chaotic distribution of Didacna valves (white shells and fragments) in conglomeratic debride of FA4 (Upper fan with distributary channels); G. Erosional contact between lacustrine marlstone base (FA1) and incised sandstone-prone channel; $\mathrm{H}$. The marlstone cape on top of the sandy-channel fan characterizes the fan lobe's "death"; I. Collapse (slump) of soft plastic marlstone on top "dying" fan.

The mollusc fauna of FA1 includes taxa like Didacna sp. 1, D. cf. loadicaense, D. elongata, Micromelania phrygica and Theodoxus bukowskii. Didacna occurs in thinly-laminated beds; its valves are often paired or in close proximity and have relatively thick shells (Fig. 3.4B). However, the most abundant mollusc remains occur in convolute beds, where they are randomly oriented; complete and fragmented Didacna valves occur together with Micromelania and locally with Theodoxus. The microfauna assemblage of the FA1 is dominated by candonids (Candona angulata, C. ex. gr. angulata) and loxoconchids (Loxoconcha muelleri, L. eichwaldi). In some levels, the ostracod valves are strongly calcified and mainly represented by Amnicythere sp. 2, Cyprideis torosa, Tyrrhenocythere pontica, T. sp., Loxoconcha petasa and L. muelleri.

Interpretation. The FA1 was deposited under low energy regimes representing distal lake floor settings. Distinct colours of laminae reflect different sediment supply sources likely controlled by seasonality: dark laminae indicate higher organic matter input during summer seasons, and lighter laminae represent relative higher carbonate supply during winters (Dean and Fouch, 1983a). Thin sandstone streaks, often with single ripple marks, define low-density turbidity flows. The low energy depositional setting is also supported by the presence of (in situ) paired bivalves. The convolute beds with randomly distributed molluscs are interpreted as slumps. Lack of organised sedimentary structures in slumps implies a non-turbiditic process of formation. Moreover, the absence of lithological changes and additional clastic material suggests that slumps were spatially limited to lacustrine marlstones, and no proximal facies were involved. Locally, the slumps display repetitive convoluted structures that may point at a seismic trigger. The ostracod and mollusc faunas of FA1 indicate oligohaline - low mesohaline salinities and episodic occurrences of thick-valved ostracod assemblages point at increased alkalinity (Checa et al., 2007; van Dijk et al., 2016). Examples of similar lacustrine facies association have been described in the Pliocene Tiberino Basin of Central Italy (Basilici, 1997).

\subsubsection{Facies Association 2 - Distal sublacustrine fan}

FA2 is represented by alternations of siltstone beds with thin $(3-10 \mathrm{~mm})$ and intermediate $(1-5 \mathrm{~cm})$ parallel lamination and disturbed convoluted beds (Figs. 3.4C, 3.5). These beds usually do not exceed $50 \mathrm{~cm}$ in thickness and have sharp, non-erosional boundaries. Inside 


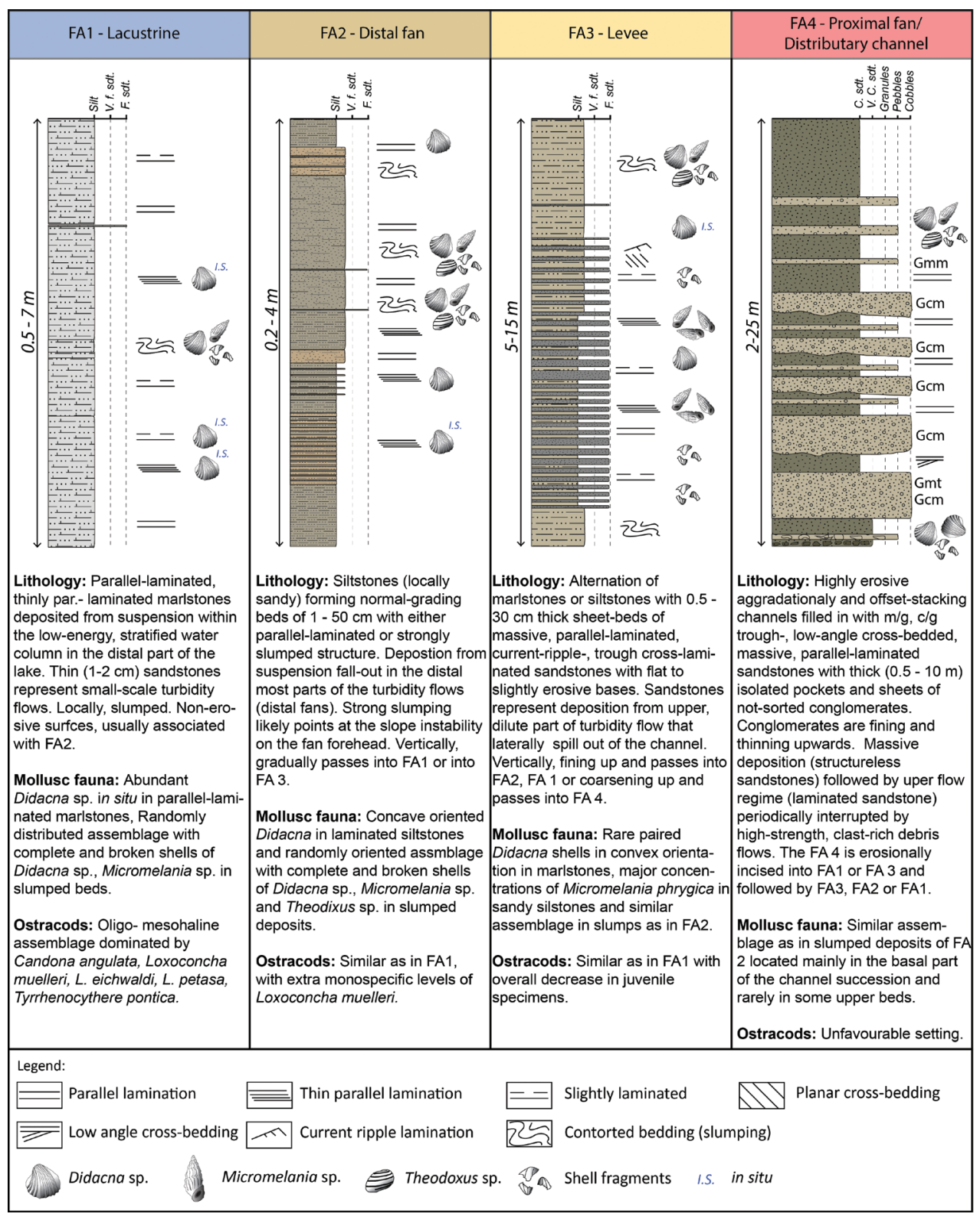

Figure 3.5. Sedimentological and faunal characteristics of interpreted facies associations.

convoluted beds, single fragments of sub-rounded siltstone clasts (maximum diameter is $20 \mathrm{~cm}$ ) were observed. Locally, the siltstone beds alternate with grey marlstone (up to $0.5 \mathrm{~m}$ ) or rare sharp-based massive sandstone ( $\mathrm{Sm}$ ) (up to $5 \mathrm{~cm}$ thick). The FA2 overlies FA1 with a gradual contact and passes into FA3. 
The FA2 mollusc fauna is similar to the FA1 fauna. Complete valves of Didacna in concavedown orientation are distributed in thinly-laminated siltstones. In convoluted beds, randomly distributed fragments and complete shells of Didacna, Micromelania and Theodoxus are present. The shells are overall strongly dissolved, but sharp ribs and details of surface structure are still preserved. Locally, at $54.5 \mathrm{~m}$, in intermediate thin parallel laminated siltstones, well-preserved imprints of leaves are found. The ostracod fauna also contains an assemblage similar to that of FA1. Candona angulata and Loxoconcha eichwaldi are dominant, and in few levels, increased abundance of nodded Cyprideis torosa as well as Loxoconcha petasa and L. muelleri is noticed. In rare cases, monospecific $L$. muelleri-dominated assemblages are present.

Interpretation. Based on fine-grain size, distinct normal-grading siltstone laminae and its relation with the other facies associations, FA2 was formed in distal fan depositional environments. The $\mathrm{mm}$-scale parallel-lamination and presence of leaf imprints are indicative for low bioturbation intensity and episodic low oxygen levels, which suggests deposition below the storm wave base. The thicker $\mathrm{cm}$-scale normal-grading siltstone beds were deposited by low-density tails of turbidity currents. Slightly higher intensity of these currents occasionally may have resulted in sandstone beds. The convoluted beds with siltstone clasts and randomly dispersed mollusc shells resulted from slumping on the fan forehead triggered by gravitational instability. The alternations of grey and white marlstones represent the transition between more distal lacustrine settings and pulses of distal fan turbidites. The ostracod fauna indicates oligohaline - low mesohaline salinities. The FA2 is similar to the outer-fan or distal lobe (Zone 4) facies association described in the Tanqua area of the Karoo Basim, South Africa (Johnson et al., 2001; Hodgson et al., 2006).

\subsubsection{Facies association 3 - Sublacustrine channel levee}

FA3 consists of interbedded fine- to medium-grained sandstones (St, Sp, Sr) and marlstones (Mh) (Fig. 3.4D, 3.5). The trough-, current ripple-, and planar cross-laminations form extensive sheet-like beds of 0.5-10 cm-thick, with sharp basal and top surfaces (Figs. 3.3E, 3.4D). The marlstones form tabular, 1-30 cm-thick beds that contain continuous sand laminae (Fig. 3.3E). Locally, deposits are convoluted (slumped: Fig. 3.4E). Laterally, towards the channel centre (FA4), the sandstones become thicker (up to $20 \mathrm{~cm}$ ), with sharp, undulating bases ( $\mathrm{Sm}$, Sh, St, $\mathrm{Sp}, \mathrm{Sr}$ ) and the white marlstones grade into pale brown sandy siltstones (Fh). At $102 \mathrm{~m}$, wellpreserved leaf imprints were found. Laterally and vertically FA3 passes into FA4 or into FA1.

FA3 contains a mollusc assemblage dominated by adult specimens of Micromelania phrygica, which often forms monospecific randomly oriented concentrations within the sandy siltstone (Fh). In some marlstone beds ( $\mathrm{Mh}$ ) paired shells and fragments of Didacna sp. 1 and fragments of $D$. laodicaense are distributed in convex-down orientation. The sandstone layers contain associations of randomly distributed fragments of Didacna, Micromelania and Theodoxus. The FA3 ostracod fauna is relatively diverse and increasingly lacks juvenile forms. 
Besides common occurrences of C. angulata and C. ex. gr. angulata, species including L. petasa ssp. 1, L. petasa ssp. 2, Maeotcythere bosqueti, Amnicythere sp. 1, A. sp. 2 and C. torosa are found. In the upper part of the section (interval 100-121 m), the ostracod valves become thicker and more ornate.

Interpretation. FA3 is interpreted as sublacustrine channel levee. Accumulation occurred as a result of the spillover of dilute turbidity flows from the feeder channels by analogy with overbank deposits in terrestrial fluvial environments (Hiscott et al., 1997). Levees deposits become thinner and their grain size smaller away from the channel. The marlstone beds represent depositional settings similar to FA1 - periods of relatively quiet deposition in a lacustrine setting with in situ Didacna pairs. The sandstones, on the other hand, demonstrate a wide variety of traction structures ( $\mathrm{Sr}, \mathrm{St}, \mathrm{Sp}, \mathrm{Sm}$ ) that characterize episodes of active turbidity flows connected with the flow within the channels. The ostracod fauna is overall taxonomically the same as in FA1 and FA2, but a quantitative drop of juvenile forms points at partial transportation and reworking. The same applies to mollusc fauna, that also represents oligohaline - lower mesohaline conditions. Preservation of leaves in sandy siltstones may presume either a high sedimentation rate, allowing fast burial and further fossilization, or low oxygenation, inhibiting bacterial decay, or both. Examples of sublacustrine channel-levee deposits (F9 and F10) similar to FA3 have been described in late Miocene deposits of the Dacian Basin (Fongngern et al., 2018).

\subsubsection{Facies association 4 - Proximal sublacustrine fan with distributary channels}

FA4 is represented by incised sandstone and conglomerate bodies (Fig. 3.5). The base of the incision infill is composed of medium- to very coarse-grained well-sorted mica sandstone, trough-cross-laminated sandstone $(\mathrm{St})$ on the margins and massive, very-coarse grained, slightly fining-upwards sandstone $(\mathrm{Sm})$ in the centre (Fig. 3.5). Locally, at the base, intraformational breccia (Ggm) is present with marlstone/siltstone rip-up clasts of up to 20 $\mathrm{cm}$ in size (Fig. 3.3J). Upwards, alternations of matrix $(\mathrm{Gmm})$ and clast $(\mathrm{Gcm})$ supported, poorly sorted, conglomerates and massive $(\mathrm{Sm})$ and horizontally laminated sandstones $(\mathrm{Sp})$ are common. Locally, conglomerate beds contain abundant mollusc fauna (Fig. 3.4F). In the central parts of incisions, conglomerate beds become thicker and more frequent and form amalgamated packages of 5-8 $\mathrm{m}$ (locally up to $15 \mathrm{~m}$ ) thick. Laterally, towards the margins, conglomerates form continuous sheet-like beds for tens of meters long, displaying single meter-scale troughs (Gmt) that gradually become thinner and grade into large scale trough- and planar-cross bedded sandstones. In the latter, numerous scours are developed. In the vertical profile, once reaching maximum thickness, conglomerate beds get gradually thinner and less frequent and finally disappear. The uppermost parts of incisions are built of trough-cross laminated, parallellaminated or massive sandstones capped by marlstones of FA1 (Fig. 3.4H). The marlstones are often slumped due to instability of the infilled channel surface (Fig. 3.4I). 
The abundant mollusc fauna is mainly associated with matrix-supported conglomerate beds (Gmm) (Fig. 3.4F). Here, the mollusc fauna includes various thick-shelled Didacna species (D. loadicaeense, D. phrygica, D. sp. 2), rarely thin-shelled Didacna sp. 1 and shells and fragments of Micromelania phrygica, Theodoxus bukowskii and Valvata cincta. The orientation of shells appears mostly random, and sorting is mostly chaotic with zones containing more or fewer small gastropods. Paired bivalves are lacking and wear patterns are variable. The faunas contain an admixture of barely to badly worn specimens as well as specimens with reasonable to good surface preservation. Posterior margins in Didacna are almost all broken, and edges are often slightly abraded. The FA4 was not sampled for micropalaeontology because of the coarsegrained nature of sediments.

Interpretation. Based on grain size, spatial distribution and relationship with other facies associations, FA 4 is interpreted as sublacustrine distributary channel - proximal fan. Channels were initiated by high-density turbulent sand-laden flows that created incisions in the lake floor by bedload transport (Fig. 3.4G) (Clark and Pickering, 1996; Di Celma et al., 2011). Formation of new channel-fans (or lobes) is linked to complete filling of the previous lobes and their avulsion (Clark and Pickering, 1996). Successive turbidity flows followed topographically advantageous pathways until the channel filled, instigating further avulsion (Clark and Pickering, 1996; Nichols, 2009). Massive sandstones in channel centres indicate higher depositional energy than on the margins, where migration of sinuous-crested dunes, expressed in trough-cross-lamination, occurred. Locally occurring intraformational breccia resulted from erosion of lacustrine beds by turbidity flows.

Sheet-beds of massive, non-sorted conglomerates with single boulders up to $1.5 \mathrm{~m}$ are interpreted as a product of periodical high-energy plastic debris flows. This interpretation is supported by complete, and randomly dispersed Didacna shells among pebbles and boulders stand for rapid transportation. Intraformational breccia, occurring just below mollusc debris, advocates destruction of the primary lacustrine deposits on the flow way. The massive (Sm) and parallel-laminated $(\mathrm{Sp})$ sandstones that overlie conglomerates correspond to the $\mathrm{Ta}$ and $\mathrm{Tb}$ parts of the Bouma sequence (Bouma, 1964). The occurrence of thick amalgamated conglomerates, their attenuation upward in succession and last blanketing by lacustrine marlstones evidences a gradual filling of the channel and its avulsion (Basilici, 1997). FA4 is similar to the inner and middle fan facies association described in the Lower Cretaceous Bogota trough, Colombian Andes (Pimpirev and Sarmiento, 1993).

\subsubsection{Channel infill and stacking architecture}

Within the studied section, two major types of channel architecture have been revealed: non-leveed and leveed-channels. These types represent distinct phases of channel evolution and can be well-classified according to 3-stages-model of the channel infill of Clark and Pickering 
(1996). In our section, the non-leveed and leveed channels vary in shape, type of enclosing rocks, and channel stacking patterns.

\subsubsection{Non-leveed channels}

The non-leveed channels are well-confined conglomerate-infilled bodies of up to 40 -m wide and 10-m thick (width/depth ratio 4:1) that are located within bigger (> 70-m wide), sandstone dominated, U-shape valleys (Fig. 3.6A). These valleys cut into the lacustrine marlstones with stepwise scour.

\section{Interpretation.}

The reconstruction of the event order in the non-leveed channel system suggests a five-stage scenario (Fig. 6A): Erosion of the lacustrine deposits (I) via initiation of the sand-prone channel (II) resulted from the bypass of the first turbidity flows downstream; Amplification of gravity flows and the occurrence of first debris flows, confined within isolated troughs (III). Here, multi-storey flows can be traced (Fig. 3.6A); A "short-term" avulsion of the channel marked by capping siltstone (IV); Installation of a smaller-scale channel on top (V) suggesting gradual attenuation of the system until it is entirely abandoned.

\subsubsection{Leveed channels}

The leveed channels are developed within the upper fans, which have a lateral width up to $300 \mathrm{~m}$. The channels are $\sim 20 \mathrm{~m}$ wide and $\sim 5 \mathrm{~m}$-thick offset-stacked conglomerate-infilled bodies (width/depth ratio 4:1)., locally with well-developed through-cross bedded sandstone wings (Fig. 3.6B). In vertical succession within the fan, channels thicken upwards until they merge into massive, up to $15 \mathrm{~m}$ thick, conglomerate bodies (Fig. 3.2, Fig. 3.7 upper right corner). Above these conglomerates, the number of channels decreases and they become thinner and sandier upwards, alternate with conglomerates sheet-beds and are finally capped by lacustrine deposits (Fig. 3.6B, 3.6C, 3.7). The channels are usually accompanied by levees (FA3) whose thickness may reach $15 \mathrm{~m}$ near the channel margins and gradually decrease in thickness away from them. The levees are usually eroded by a successive generation of channels (Fig. 3.6C).

\section{Interpretation.}

A three-stage formation of the leveed channels can be defined: I. Progradation and growth of the upper fan due to constant supply dense sand-laden turbidity flows. The flows confine into the channels, and their dilute part forms levees along the channels; II. Channels serve as the major conduit for the through-put of debris flows. The gradual build-up of the fan initially leads to the formation of offset-stacked channels formed on top of the previous channel's levee. After that, the gradual infill of the fan-channels leads to the retreat of new debris flows (backfill); III. Mass flow intensity decreases, and only exceptional large flows result in deposition of 


\section{CHAPTER 3}
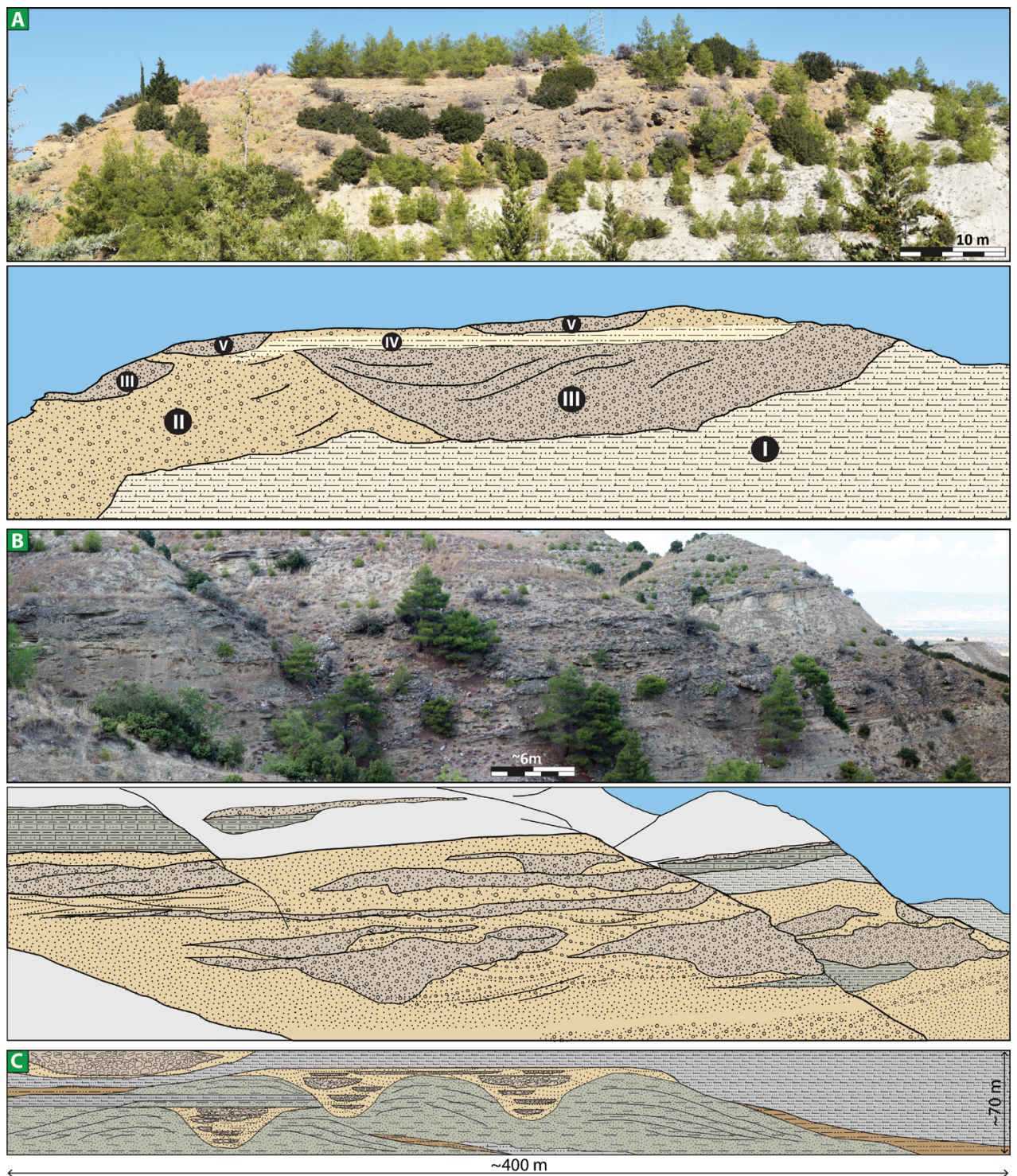

Lacustrine (FA1): marlstones
Distal fan (FA2): siltstones
Levee (FA3): Interbedded marlstones/siltstones and sandstones

\begin{tabular}{ll}
\hline & Upper fan (FA4): sandstones and conglomerate \\
0 & Distributary channels (FA4): conglomerates \\
\hline$\quad$ Indetermined \\
\hline
\end{tabular}

I Reconstructed event order

Figure 3.6 Photos, line-drawing interpretation and depositional architecture of: A. Non-leveed channel s;

B. Leveed channels. C. Reconstruction of relations between elements of sublacustrine channel-system. 
conglomerate-sheet beds. Subsequent new turbidity flows take another topographicallybeneficial path attenuating the previous fan and blanketing it with lacustrine marls.

\subsubsection{Stratigraphic succession}

The here studied early Zanclean depositional record of the Denizli Basin displays a gradually coarsening upwards succession of siltstone, sandstone and conglomerate packages interbedded within lacustrine marlstone. The lower part of the succession $(0-58.5 \mathrm{~m})$ displays alternations of 0.5-8 m packages of white marlstone deposited in distal lacustrine settings (FA1) and brown, frequently slumped siltstone and packages of $0.5-5 \mathrm{~m}$ representing the distal sublacustrine fans (FA2) (Fig. 3.2, 3.7). In the middle part of the studied succession (58.5-124.5 m), an increase of the amount of fine- to medium-grained sandstone, occurring in a shape of thin interbeds among marlstone and siltstone, characterizes the sublacustrine channel levee deposits (FA3, Fig, 3.2, 3.7). Towards the top, between 124.5 and $186 \mathrm{~m}$, the succession displays up to $25 \mathrm{~m}$ thick conglomerate-prone bodies capped by up to $5 \mathrm{~m}$-thick packages of marlstone (FA1) and sandstone-marlstone (FA3). The palaeocurrent directions measured from distributary channels are oriented towards $0-30^{\circ} \mathrm{NNE}$. The generally coarsening upward succession indicates a progradation of the channel-fan system.

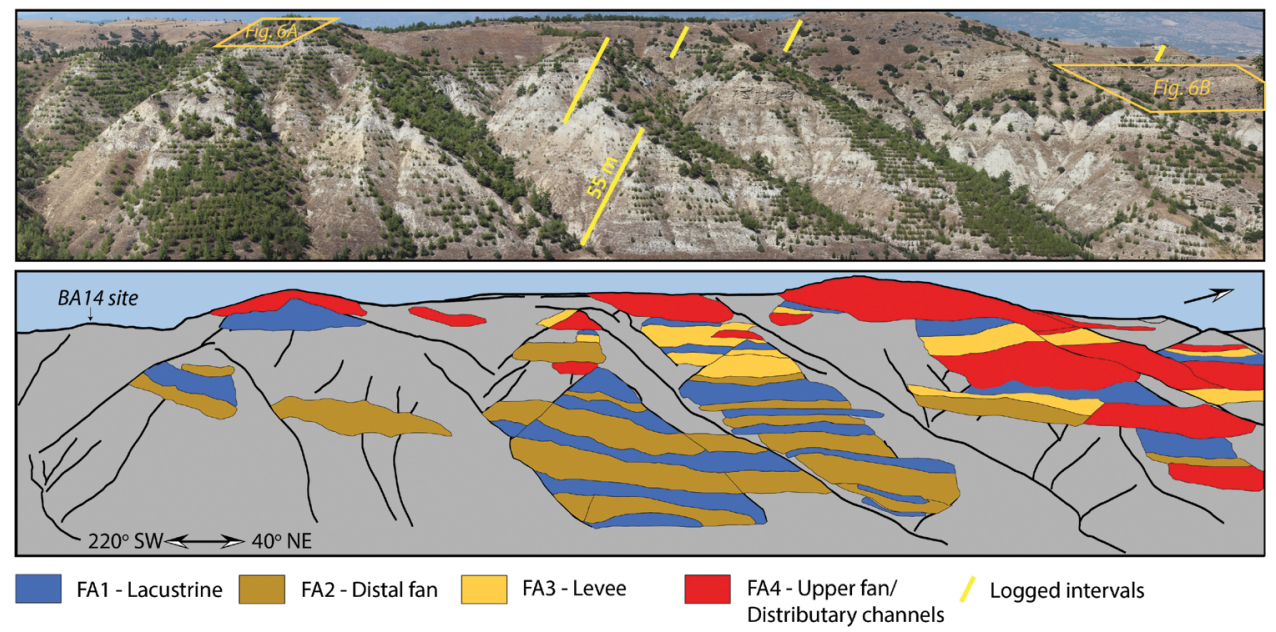

Figure 3.7 Panoramic view on the studied section and depositional system reconstructed through the line-drawing and closer observations.

\subsection{Discussion}

\subsubsection{Sedimentary processes and palaeoenvironments}

The depositional architecture of the early Zanclean sediments in the upper Kolankaya Formation of the Denizli Basin records a prograding sublacustrine channel-fan system (Fig. 
3.8). The facies model displays several features formed by sediment-laden, high-energy turbidity flows, possibly related to palaeoseismic activity.

The facies analysis suggests that most of the depositional processes in the studied system were instant and highly energetic. The thinly parallel-laminated lacustrine marlstones characterize depositional processes in quiet, low-energy environments, below the storm-wave base (Dean and Fouch, 1983b). Major disturbances in lacustrine facies, expressed in convoluted beds are potentially linked to instability of the lacustrine bottom (slumps) (Oliveira et al., 2011) as well as being induced seismically (seismites) (Rodriguez-Pascua et al., 2000; Üner, 2014). Thin-laminated - convoluted sets in siltstones are linked to the most mobile, and distal parts of turbidity flow followed by accumulation from residual suspension (Bouma, 1964; Nichols, 2009). Sandstone sheet-beds with planar cross-lamination, current-ripples, troughcross lamination and non-erosive contacts were accumulated along the channel axis due to overspill of the major turbidity flows (Bouma, 1964; Peakall et al., 2000; Nichols, 2009). The intraformational mud clast breccia indicates a rapid flow cutting into lacustrine deposits and transporting mud-fragments downslope (Fielding, 2010; Di Celma et al., 2011). The facies analysis suggests that the majority of depositional processes in the studied system were sudden and episodic, turbidity and debris flows.

The uppermost part of the Kolankaya Fm. with sandstone-conglomerate-dominated content (e.g. Units 3 and 4, Alçiçek et al., 2007a) was previously considered as fluvial (Westaway et al., 2004) or as subaerially exposed lake shoreface and foreshore deposits (Alçiçek et al., 2007a). The oxygen isotope data from lacustrine marlstones preceding the major conglomerates were interpreted as reflecting an increase of salinity and a hydrological change towards a closed character of the basin (Alçiçek et al., 2007a). Furthermore, the progradation of conglomerates was interpreted as shrinking and freshening of the lake (Alçiçek et al., 2007a). Our facies analysis proposes that these deposits represent sublacustrine channel-fans instead (Fig. 3.8). The channel-fans are laterally restrained and incised into lacustrine marlstone and thus cannot represent a basin-wide shoreline progradation. Being laterally surrounded by lacustrine marlstone, the channel-fans were deposited in relatively deep (below storm-wave base) lacustrine settings. The micropalaeontological data throughout the section, namely below, above and in between the fans (Fig. 3.2) shows the constant presence of oligo - low mesohaline assemblages dominated by loxoconchids and candonids with the presence of Maetocythere and Amnicythere; freshwater assemblages are absent. Similar mesohaline dominant mollusc assemblages occur with the only limited influx of clearly reworked freshwater taxa. Moreover, the lack of terrestrial indicators such as oxidation, mud cracks, pedogenic modification, rootlets, and terrestrial in situ (ichno) fossils, excludes a subaerial origin for the facies associations. We have no indications for changing depositional water depths through the series. 


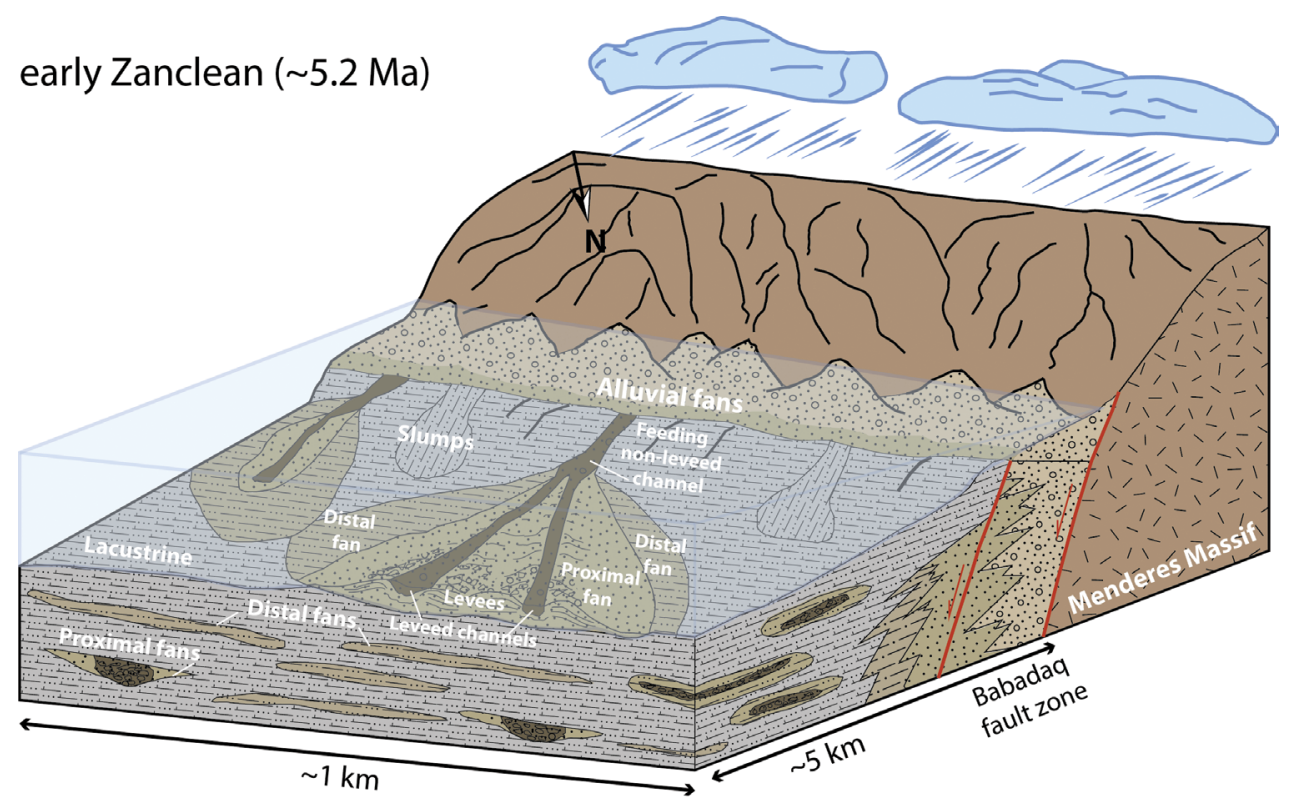

Figure 3.8. A. schematic model of the depositional environments of the Denizli Basin in the early Zanclean.

\subsubsection{Potential drivers of depositional environments}

The depositional architecture and evolution of deep water channel-fan systems are generally driven by allocyclic forcing, even though, at a lower scale of single fan lobes (fan lobe switching) autocyclic control may be the dominant process (Hickson and Lowe, 2002; Di Celma et al., 2011). Average sedimentation rates (Chapter 2 ) for the $185 \mathrm{~m}$ interval imply a very short $(\sim 100-$ $240 \mathrm{ky}$ ) duration of its formation. It is comparable with the duration of one or two 100-kyr eccentricity cycles and with 2-7 obliquity cycles (Hilgen et al., 2012). However, the upper limit of the section stops short before the maximum development of the channel-fans hampering the further evolution of the system, as well as its duration and potential astronomical forcing.

\subsubsection{Base level changes}

Deep-water fan systems are commonly considered to be formed during falling sea level stages (Covault, 2011) even though, more complex relationships between fan system development and sea-level change also exist (Posamentier et al., 1991; Di Celma et al., 2011). During base-level fall, accommodation space previously available on the shelf (or nearshore littoral part) moves basin-wards allowing delivery of coarse-grained sediment supply into the deeper parts of the basin (Covault, 2011). Such a mechanism has been proposed in the Palaeozoic Karoo Basin (Di Celma et al., 2011) and modern Lake Malawi (Soreghan et al., 1999). In these two African systems, the expressions of base-level fluctuations are intrabasinal 
erosional surfaces between depositional units. Such surfaces, however, were not detected in the studied record of the Denizli Basin. The erosional surfaces may potentially be absent (or not visible) in distal, deep water parts of the basin where base-level changes are less pronounced.

The channel-fans in the Denizli Basin were formed in relatively deep water environments, below the storm wave base. However, the position of this level in a small and wind-protected basin like Denizli can be much shallower than in open marine settings. Moreover, the section is only $5 \mathrm{~km}$ away from the southern basin margin and about $4 \mathrm{~km}$ away from the nearest alluvial fan (Fig. 3.1). The base-level fluctuations in isolated basins are usually of higher frequency and amplitude (Shanmugam et al., 1985; Soreghan et al., 1999; Krijgsman et al., 2010) than in the global ocean. The proximal location of the section implies that well-pronounced base-level changes could have impacted the formation of lacustrine marlstones (FA1) by replacement with coarser sediments arriving from prograding delta or alluvial fans during lake level drops. Instead, no changes in lithology of lacustrine marlstone were observed. The lack of lithological changes in deep-water lacustrine marlstones through time and the absence of intrabasinal erosional surfaces do not support a significant role of base-level fluctuations in the evolution of the Denizli sublacustrine channel-fans.

\subsubsection{Tectonic drivers}

The depositional processes in extensional basins are generally tectonically controlled through basin-bounding normal faults (Basilici, 1997; Soreghan et al., 1999; Allen and Densmore, 2000; Gawthorpe and Leeder, 2000; Sümer et al., 2012). Movements along the faults create footwall and hanging wall blocks that define the basin topography (Gawthorpe and Leeder, 2000). Footwall erosion feeds prograding fans. The size of the fan system is controlled by slip rate and intensity of growth and progradation of associated normal faults (Allen and Densmore, 2000; Gawthorpe and Leeder, 2000).

The depositional record of the extensional Denizli Basin has also been tectonically controlled throughout the entire basin history (Seyitoğlu and Işık, 2015). The Kolankaya Formation displays syn-sedimentary tectonic disturbances along the Babadağ Fault zone expressed by wedge-shaped alluvial fans thickening towards the footwall blocks of proximal faults (Seyitoğlu and Işık, 2015), and by the abundance of seismites (Koçyiğit, 2005; Topal and Özkul, 2014). Such features suggest that the Babadağ Fault zone acted as a growth fault during deposition of the Kolankaya Formation (Seyitoğlu and Işık, 2015).

The palaeocurrent directions of the sublacustrine channels, measured in our section and sections nearby (e.g. Babadağ 7-log, Ba14 site, Alçiçek 2007), are mostly towards 0-30 NNE, which is perpendicular to the WNW-ESE trending Babadağ Fault Zone (Fig. 3.1). Such orientation defines the fans as transverse depositional systems (Gawthorpe and Leeder, 2000) and points at a direct link with the normal faults. Palaeomagnetic data indicated extreme high sedimentation rates of $>1.5 \mathrm{~m} / \mathrm{kyr}$ within the lower fine-grained part of the Kolankaya 
Formation that evidence sufficient accommodation space created by active basin subsidence (Chapter 2).

The Pliocene history of the Denizli Basin is characterised by the intensification of the Menderes Massif uplift (Westaway et al., 2004; Seyitoğlu and Işık, 2015). In the Gediz Graben to the north and Büyük Menderes graben to the south, the post-Miocene deposits consist of unsorted conglomeratic sheet-beds normally grading into sandstones and marlstones. Similar to the Denizli Basin, these high-energy deposits are prograding, away from the basin-bounding faults and considered a result of the activation of detachment faults (Çiftçi and Bozkurt, 2009; Gürer et al., 2009).

The link of the channel-fans with basin-bounding faults, the observed high sedimentation rates and presence of seismites in lacustrine deposits suggest that increased Menderes Massif uplift expressed in the vertical movements along the detachment, basin-bounding normal faults played a major role in the progradation of the studied sublacustrine channel-fan system.

\subsubsection{Climatic drivers}

An alternative explanation for the transport of coarse clastic material into the basin is the increased erosional potential of rivers bringing material from the Menderes Massif. This can, for instance, be achieved by more intense precipitation (Forzoni et al., 2014). The onset of the sublacustrine channel fan systems in the Denizli Basin is magneto-biostratigraphically dated at $\sim 5.5 \mathrm{Ma}$ (Chapter 2). At that time the circum-Mediterranean region experienced a significant hydrological change towards warmer and wetter conditions (Hodell et al., 2001; Hilgen et al., 2007; Roveri et al., 2014a). The nearly-desiccated Messinian Mediterranean Basin became first filled with brackish water (Lago Mare stage) followed, at $5.33 \mathrm{Ma}$ by the re-establishment of modern Mediterranean marine conditions (Hsü et al., 1973; Krijgsman et al., 2018; Micallef et al., 2018). After 5.5 Ma the Mediterranean thus became (again) a regional moisture source that could have driven increased precipitation, such as those documented from early Zanclean intervals in Anatolia (Kayseri-Özer, 2017; Meijers et al., 2018). This early Zanclean precipitation increase may have resulted in coeval lake development and deepening in isolated groups of basins: the Denizli, Söke and Yatağan basins and the Karacasu, Bozdoğan, Çameli and Eşen (Alçiçek, 2007b; Kaya et al., 2012; Alçiçek and Jiménez-Moreno, 2013; Sümer et al., 2013; Alçiçek et al., 2019). All these basins (except Denizli Basin) show changes from sandstone/ conglomerate-dominated facies to claystone/limestone-dominated facies characterizing the expansion of lakes (Alçiçek, 2010).

Increased runoff is expected to have caused a decrease of water salinity and hence should be reflected in the biotic record. The fossil mollusc and ostracod assemblages from the lower (before major progradation) and upper (in between fans) parts of the section both represent oligo- low mesohaline environments. Thereby, the depositional record does not indicate 
freshening of the basin throughout the section. This indirectly declines the idea of a potential rise of riverine.

\subsubsection{Evolution of the Denizli deep-water channel-fans}

Submarine and sublacustrine channel-fan systems are well studied (Pimpirev and Sarmiento, 1993; Clark and Pickering, 1996; Soreghan et al., 1999; Allen and Densmore, 2000; Gawthorpe and Leeder, 2000; Hickson and Lowe, 2002; Mack and Stout, 2005; Covault, 2011; Di Celma et al., 2011; Morris et al., 2014; Dodd et al., 2019). The marine and lake systems generally have similar architectural elements but differ in size and controlling processes. Development of submarine systems mostly relies on sea-level fluctuations (Di Celma et al., 2011) whereas, in sublacustrine systems, tectonic factors play a major role (Mack and Stout, 2005). However, systems with complicated mixed controls are also known (Soreghan et al., 1999).

Based on the analysis of facies, mollusc and ostracod fauna, depositional architecture and spatial distribution, we propose a new depositional model of the early Zanclean Denizli Basin (Fig. 3.8). The channel-fan system of the Denizli Basin has two remarkable features relatively small size with prograding distance of $\sim 5-8 \mathrm{~km}$ and infill with high energy $(\mathrm{Gcm}-$ facies) debris flows (Fig. 3.2, 3.3G, 3.6, 3.8). Comparison of the Denizli system with the Permian submarine slope channel-levee system of the Karoo Basin (South Africa) revealed resemblance in development phases between these two systems (Johnson et al., 2001; Hodgson et al., 2006; Di Celma et al., 2011). The study of Di Celma et al. (2011) subdivided three distinct phases of the Karoo channel-levee-fan system evolution: 1. Initiation Phase (their Sub-Unit C1): progradation of sand-dominated packages of unit $\mathrm{C}$ on the mud-dominate submarine slope. Formation of gull-winged leveed channels; 2. Growth Phase (Subunit C2): The active growth of the system characterised by the increased incision of the channels, their infill and repetitive channel cutting, bypass, backfilling etc. In this phase, the system developed the most complex channel-belt structure with laterally stacked channels; 3. Retreat Phase (Subunit C3): Reduction of the sediment delivery and basin margin retreat of the system.

Compared to Karoo, in Denizli, the initiation phase is marked by the occurrence of brown siltstone (FA2) representing the lightest by-passed part of turbidity flows. In the proximal part of the section, this is followed by the initiation of non-leveed channels that incised into lacustrine sediments (4.3.1). The subsequent channel-fan progradation, characterised by the formation of leveed channels, corresponds to the growth phase. The retreat phase is not presented in our system as the section stops at the maximum expansion of the channel-fans. Nevertheless, at a smaller scale, the channels demonstrate the retreat phase and the lobe switch expressed in fining upward-trends (Fig. 3.2, 3.7). The submarine Karoo channel-fan system was interpreted to be controlled by climatically-driven eustatic fluctuations with the maximum fan progradation during the lowstand (Di Celma et al., 2011). 
A modern example of sublacustrine channel-fans is from Lake Malawi, which has a similar tectonic setting as the Denizli Basin. Being formed within the western arm of the East African Rift System, Lake Malawi rests in three major half-graben basins bounded by normal faults (Soreghan et al., 1999). Here, similar to Denizli, sand-dominated canyon-channel-fan systems spread basinward perpendicular to the faults. Both fault tectonics and lake-level fluctuations were considered as major drivers of the growth and progradation of the fans (e.g. Soreghan et al., 1999). Progradation in Lake Malawi is linked to the lake lowstands that resulted in the erosion of proximal alluvial fans, re-activation of canyons and supply of eroded material to distal sublacustrine fans.

The Denizli channel-fan system combines features of both, the base-level-controlled channel-fan system of the Karoo Basin and tectonically-driven system in the Lake Malawi. The Denizli channel-fan system underwent similar initiation and growth phases as the Karoo Basin system showing a similar structural link with basin-bounding faults as in the Lake Malawi. Nevertheless, unlike the African systems, the progradation of sublacustrine-channel fans in Denizli was likely driven by the activity of the basin-bounding Babadağ Fault Zone rather than by fluctuations of the base level. The direct impact of the climatic factor on the evolution of Denizli channel-fans yet remains under discussion.

\subsection{Conclusion}

The extremely well exposed $185 \mathrm{~m}$ depositional record of the upper Kolankaya Formation of the Denizli Basin has been subdivided into 11 distinct lithological facies. Based on the reciprocal distribution of lithological facies, architecture and taphonomic features, 4 facies associations have been distinguished: lacustrine (FA1), distal fan (FA2), distal and proximal sublacustrine channel-levee (FA3) and upper fan with distributary channels (FA4).

Taphonomic analysis on mollusc fauna showed a high impact of turbidity and mass transport processes on habitat and post-mortal burial of mollusc assemblages. The lacustrine FA1 contains in situ and reworked assemblages with Didacna mollusc, while the others comprise mostly reworked nearshore assemblages with Micromelania, Theodoxus and Didacna genera. The fauna reworking was mostly triggered by slumping within FA 1 and 2, turbidity currents in FA 3 and dense debris flows in FA4. The ostracod association in lacustrine, distal fan and levees (FA1, FA2, and FA3 respectively) consists of oligo-, low mesohaline assemblages dominated by the genera Loxoconcha, Amncythere, Candona, Cyprideis and Maetocythere and do not show any major environmental changes. The application of mollusc and ostracod proxies helped to determine that in the early Zanclean the Denizli basin was an oligo- low mesohaline lake with gradually increasing freshening of the marginal parts.

Three evolutionary stages can be distinguished: 1) Initiation, marked by the formation of erosional non-leveed channels that served as major route for initial bypassing turbidity flows; 2) Growth, characterised by the establishment of sandstone-prone, leveed channels 
that channelled frequent high energy conglomerate debris flows; 3) Attenuation, representing the backfilling of the fan, from conglomerate-prone channels to massive sandstones with thin sheet-beds of exceptional conglomeratic debris flows and blanketing by lacustrine marlstones. Tectonism was the main driver of channel-fan progradation. Features of base-level fluctuations such as progradation of proximal facies (delta or alluvial fan) or intrabasinal erosional surfaces, were not found in the studied record suggesting that base level changes were not primarily responsible for progradation of sublacustrine channel-fans in the Denizli Basin.

Our study provides a more detailed reconstruction of the depositional environment in the Denizli Basin and gives new insights not only in the architecture of the systems but also its impact on palaeoecosystems. Our study may be used as an analogue for future sedimentological studies in numerous extensional lacustrine basins around the world. 
DEPOSITIONAL ARCHITECTURE OF SUBLACUSTRINE CHANNEL-FANS 



\section{Part}

Magneto-Biostratigraphy, PALAEOENVIRONMENTS AND FAUNAL TURNOVERS IN THE KURA BASIN DURING THE LATEST PlioceneMiddle Pleistocene. 


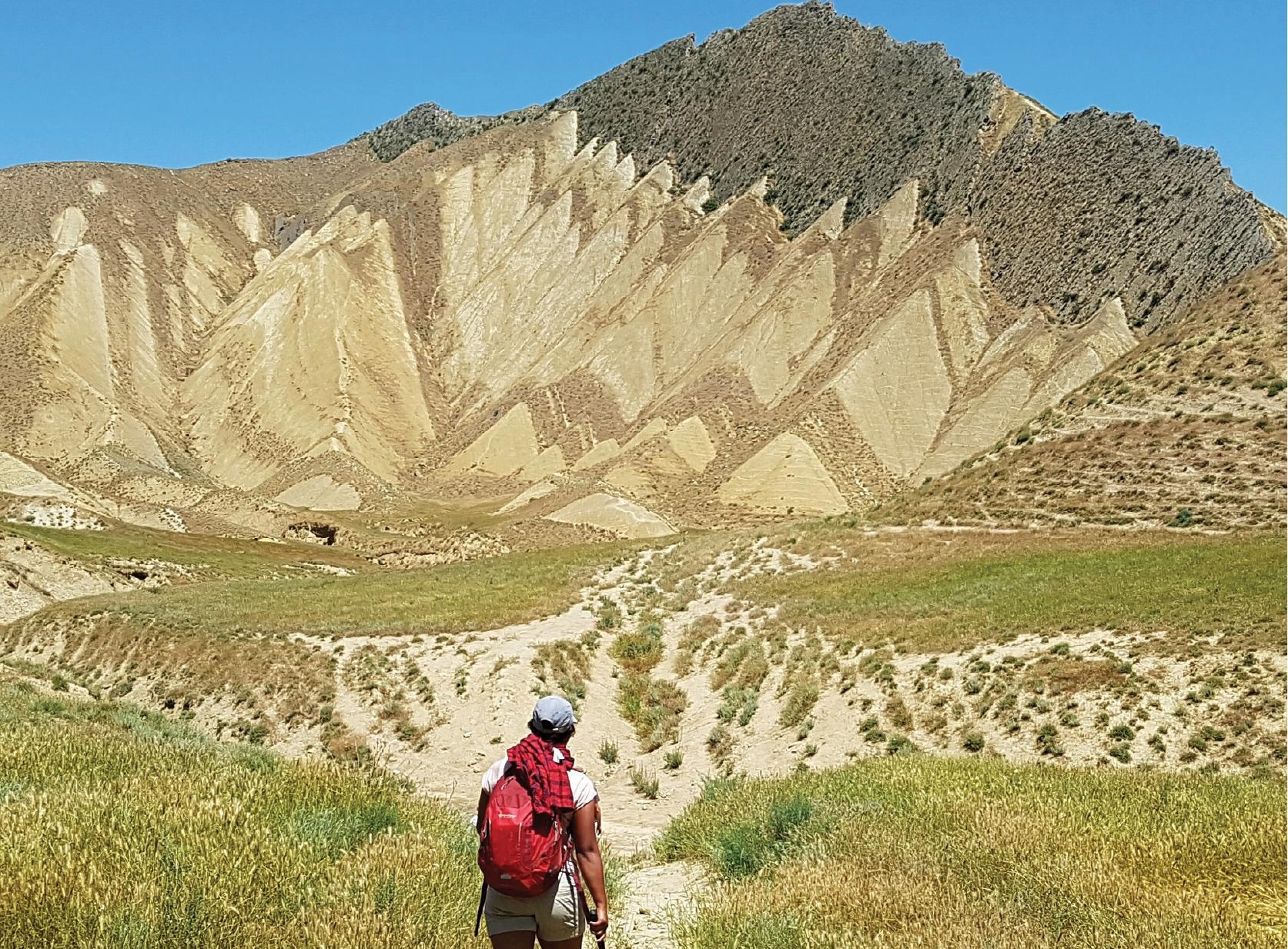
2. (2) (1) (2)

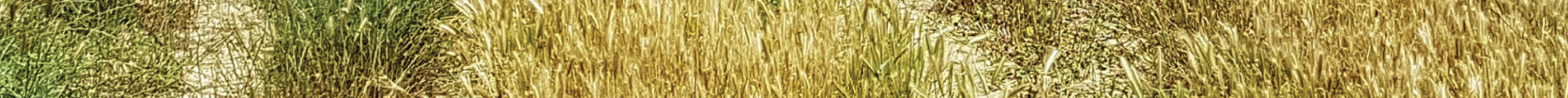

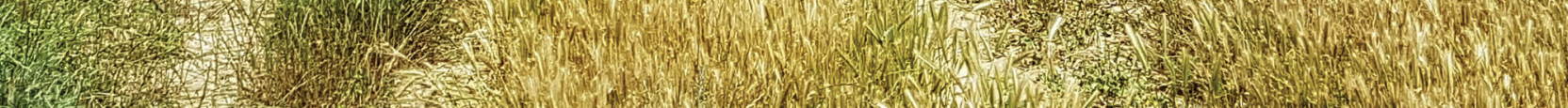

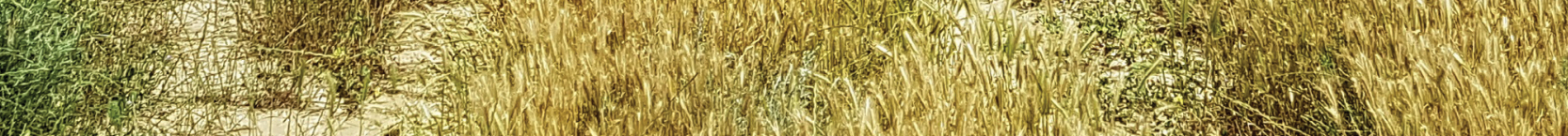

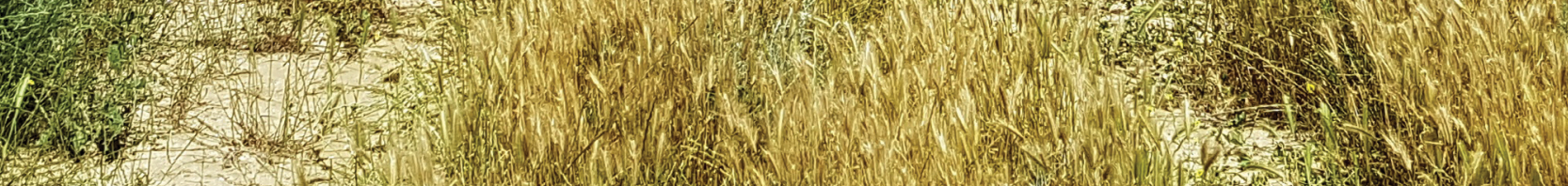

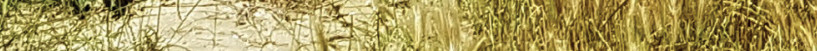

The Hajigabul section better known among our friends as a "Dream section" is about $1.4 \mathrm{~km}$ thick and exposes the entire late Pliocene - Middle Pleistocene record of the Kura Basin. On 


\section{4}

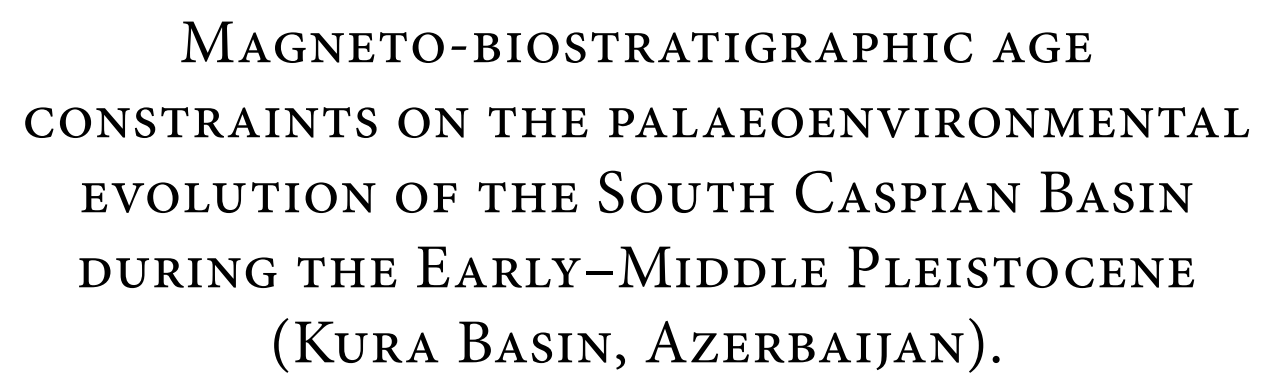

Published:

Lazarev, S., Jorissen, E.L., van de Velde, S., Rausch, L., Stoica, M., Wesselingh, F.P., van Baak, C.G.C., Yanina, T.A., Aliyeva, E., Krijgsman, W., 2019. Magnetobiostratigraphic age constraints on the palaeoenvironmental evolution of the South Caspian basin during the Early-Middle Pleistocene (Kura basin, Azerbaijan). Quaternary Science Reviews 222, 105895 . 10.1016/j.quascirev.2019.105895. 


\section{Abstract}

The sedimentary record of the Caspian Basin is an exceptional archive for the palaeoenvironmental, palaeoclimatic and biodiversity changes of continental Eurasia. During the Pliocene-Pleistocene, the Caspian Basin was mostly isolated but experienced large lake level fluctuations and short episodes of connection with the open ocean as well as the Black Sea Basin. A series of turnover events shaped a faunal record that forms the backbone of the Caspian geological time scale. The precise ages of these events are still highly debated, mostly due to the lack of well-dated sections. Here, we provide an integrated magneto-biostratigraphic age model for two sections from the Kura Basin - Goychay and Hajigabul. Our results reveal several major intervals with elevated salinity, associated with mesohaline faunas, and propose the following age constraints: 1) The Productive Series-Akchagylian boundary is marked by a marine transgression from the open ocean that occurred around the Gauss-Matuyama reversal ( 2.7-2.6 Ma); 2) The Akchagylian-Apsheronian transition is characterised by a regression event and introduction of a new, "Pontocaspian" mollusc assemblage, dated within the Reunion subchron $(\sim 2.13 \mathrm{Ma})$. The ostracod assemblages of the two sections do not show a major faunal turnover here; 3 ) The early Bakunian transgression occurs after the upper Apsheronian lowstand (0.85-0.83 Ma). We conclude that major transitions in the age-indicative mollusc groups sometimes occur at different time intervals (i.e. diachronic) and are highly depended on the local depositional environments. A high-resolution interdisciplinary approach on sections outside the Kura Basin is required to understand better the potential diachroneity of these turnover events in the entire Caspian Basin.

\subsection{Introduction}

The Caspian Sea is an endorheic basin, located between Eastern Europe and Central Asia. Even though the Caspian Sea has marine aspects (salinity, particular faunas), it is technically a long-lived lake, and it is the largest lake in the world. The Caspian Basin became isolated from the Paratethys Sea during the latest Miocene (Popov et al., 2006; van Baak et al., 2017). Since that time, the Caspian Sea went through periods of dramatic lake-level drops and spectacular expansions. The Caspian Sea was mostly isolated but periodically connected to the Black Sea Basin and global ocean (Krijgsman et al., 2019). Consequently, a unique fauna evolved in the Caspian Basin through a series of big turnover events. The sedimentary record of the Caspian Sea Basin provides a comprehensive geological archive to study these faunal changes and the coeval climatic and environmental history of Eurasia.

The complete geological successions crop out in the South Caspian Basin (including the Kura Basin and the West Turkmenian Depression). Here, active tectonic uplift of the basin margins and hinterlands, accompanied with high subsidence rates in the basin, preconditioned accumulation of kilometres of sediments since the late Miocene (Allen et al., 2002; Morton et al., 2003; Forte et al., 2015). A succession of endemic species (Kirsanov, 1972, cited in 
Trubikhin, 1977) that occupied the anomalohaline ("brackish") lakes of the South Caspian Basin has been used to erect regional stratigraphic schemes. The Pliocene-Middle Pleistocene succession of the South Caspian Basin is subdivided into several regional stratigraphic stages: Akchagylian, Apsheronian, Bakunian and Khazarian (Muratov and Nevesskaya, 1986; Jones and Simmons, 1997). These regional stages have been uniformly applied to the entire Caspian Basin (Nevesskaya et al., 2004; Zastrozhnov et al., 2013). However, the tectono-sedimentary histories of the North, Middle and South Caspian basins have been very different. They might have resulted in the diachronous evolution of depositional environments and associated faunas (e.g., Forte et al., 2015).

Furthermore, preservation potential and lateral variability of habitats, which may affect the definition of regional biostratigraphic stages, remain largely unexplored. Well-preserved deep water faunas are often lacking, and in shallower settings, faunas may respond to local palaeoenvironmental change rather than represent basin-wide synchronous turnover events (Markova, 1962; Magyar et al., 2013). In this paper, we study two long sections in Azerbaijan covering the Productive Series to the Khazarian regional stages, straddling the interval $\sim 3-0.5$ Ma. The Goychay and Hajigabul sections are located in proximal and distal settings in the Kura Basin, respectively.

The aim of this study is to characterize major depositional units and combine magnetostratigraphic and biostratigraphic (molluscs and ostracods) approaches to develop an integrated stratigraphic framework, which will facilitate the identification of major drivers of regional palaeoenvironmental changes.

\subsection{Geological background}

\subsubsection{The South Caspian Basin: setting and structure}

The Caspian Sea is elongated in a meridional direction and overlies several tectonicstructural zones, forming three sub-basins: North, Middle (Central) and South Caspian basins (Fig. 4.1A). The North Caspian Basin is a depression that was formed in the Late Proterozoic (Khain et al., 2004; Khain and Popkov, 2009) on the East European platform. Its sedimentary infill contains several distinctive complexes: Early Palaeozoic, Devonian-Permian, PermianTriassic and Jurassic-Quaternary. The basement of the Middle Caspian Basin consists of Late Proterozoic metamorphic rocks of the Scythian Platform with a complex of Mesozoic and Cenozoic sedimentary rocks on top (Khain et al., 2004; Green et al., 2009). The South Caspian Basin is linked to the Alpine-Himalayan orogenic belt of the Greater Caucasus and forms the most tectonically active part of the Caspian Sea (Jackson et al., 2002). It consists of the South Caspian Depression and a complex of surrounding foredeep basins: the Kura, West Turkmenia and Absheron-Gobustan depressions (Brunet et al., 2003; Khain et al., 2004; Forte et al., 2013; Forte et al., 2015). The basement of the South Caspian Depression is considered to be either 
oceanic crust or attenuated, high-velocity continental crust (Mangino and Priestley, 1998). The complex of sedimentary rocks that overlies the basement has a thickness of up to $20 \mathrm{~km}$, most of which accumulated during latest Miocene-Pliocene (Allen et al., 2002; Brunet et al., 2003; Morton et al., 2003; Green et al., 2009).

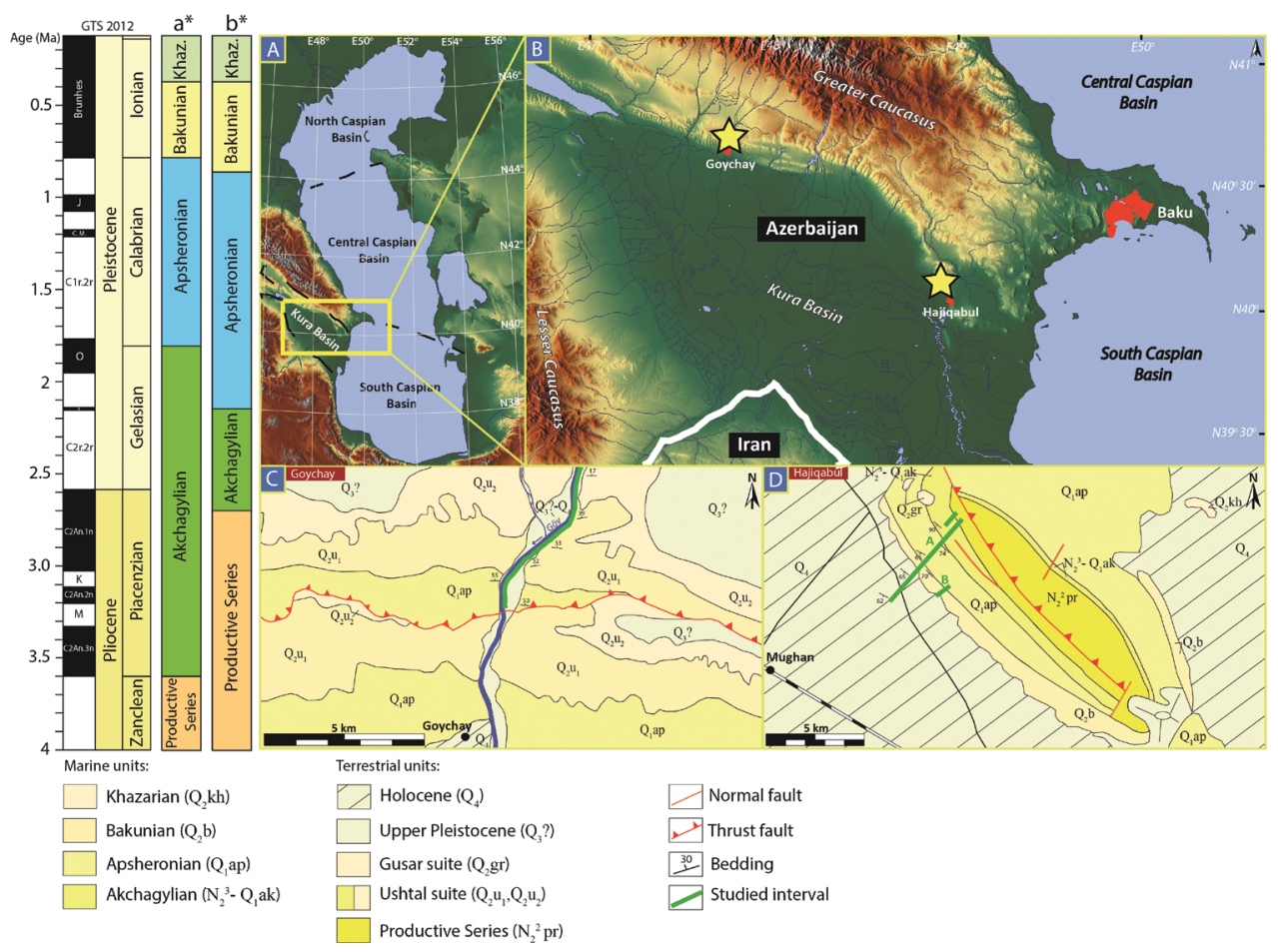

Figure 4.1 Location map of the Goychay and Hajigabul sections. Columns on the left: Global polarity time scale (Hilgen et al., 2012) Epoch/Age; Regional Stages: $\mathrm{a}^{*}$ classical definition (Shantser, 1982; Arslanov et al., 1988; Nevesskaya et al., 2003; Nevesskaya et al., 2004), b this study. Position of the studied sections in relation to the Caspian Sea (A) and to the Kura Basin (B) (The map base is taken from www.maps-for-free. com); Geological maps for the Goychay section (C) and the Hajigabul section (D) modified after Bairamov et al. (2008).

The Kura Basin is the western extension of the South Caspian Basin and the foreland basin between the Lesser and Greater Caucasus mountain ranges (Fig. 4.1B). Because of the extreme depth (up to $20 \mathrm{~km}$ ), the composition of the basement of the Kura Basin is poorly known. It may be a westward continuation of the South Caspian Basin basement (Zonenshain and Le Pichon, 1986), containing Early Palaeozoic crystalline rocks (Azizbekov, 1972) and/or the remnant of a Mesozoic island arc (Nadirov et al., 1997). The late Cenozoic history of the Kura Basin is closely linked to the amplification of the Arabian - Eurasian collision that caused progradation 
of the Kura thrust fold belt (Forte et al., 2010). This belt accommodated most of the post $5 \mathrm{Ma}$ shortening, which is expressed in a series of well-exposed sedimentary successions, located along the northern flank of the Kura Basin. This late Cenozoic sedimentary sequence is about $5-7 \mathrm{~km}$ thick and is similar to that found in the South Caspian Basin (Mangino and Priestley, 1998; Allen et al., 2002; Forte et al., 2010).

\subsubsection{Caspian Sea: from Paratethys to an isolated basin}

The Caspian Sea became isolated during the fragmentation of the Paratethys, a large epicontinental sea reaching in the Oligocene from the Molasse Basin in France in the West to the Tien Shan mountains in western China in the East (Laskarev, 1924). The Paratethys has been shrinking in size throughout its Neogene and Quaternary history due to the ongoing collision between the African, Arabian and Eurasian plates (Rögl, 1999; Schulz et al., 2005; Popov et al., 2006). Isolation of the Caspian Sea from other Paratethyan basins occurred during the latest Miocene, around 5.6-5.5 Ma (Allen et al., 2002; Jackson et al., 2002; Allen et al., 2003). At that time, a complex combination of climatic and tectonic factors led to a major Paratethys sea-level drop (Krijgsman et al., 2010; van Baak, 2015a; van Baak et al., 2017). Consequently, intensification of the Caucasian orogeny provoked a permanent closure of the Ciscaucasian Strait and thus, isolation of the Caspian Basin from the Euxinian (Black Sea) Basin (Popov et al., 2010).

During the early Pliocene, both climatic and tectonic factors contributed to a large lakelevel drop in the Caspian Basin (Kroonenberg et al., 2005). The basin reduced in size to the South Caspian Depression and deep river canyons eroded into the desiccated North and Central Caspian basins (Kroonenberg et al., 2005). The Palaeo-Volga, Palaeo-Kura and PalaeoAmu-Darya deltas reached the South Caspian Basin and locally deposited about 7-8 km of sediments (Morton et al., 2003; Green et al., 2009; Abdullayev et al., 2017). This Pliocene lakelevel lowstand was initiated around 5.3 Ma and had resulted in the deposition of the Productive Series - a sequence of interbedded and regionally continuous lacustrine mudstones and fluviodeltaic sandstones that form main hydrocarbon reservoirs in the South Caspian region (Aliyeva, 2005; Kroonenberg et al., 2005; Vincent et al., 2010). The Productive Series was terminated by the late Pliocene Akchagylian transgression (Nevesskaya and Trubikhin, 1984; Popov et al., 2006; Green et al., 2009).

\subsubsection{Late Pliocene-Early Pleistocene regional stages and boundaries}

From the late Pliocene onwards, a succession of anomalohaline lake stages with characteristic endemic faunal suites developed (Nevesskaya and Trubikhin, 1984; Danukalova, 1996). The stratigraphic boundaries of these stages are subject of scientific debate (Krijgsman et al., 2019) The first research on the Caspian stratigraphy started at the end of the 19th century with the works of Sjögren, Andrusov and Barbot-de-Marni (Vereshchagin, 1982). Ever since, 
the definitions of stratigraphic units have been discussed, further documented and updated (Andrusov, 1918; Borissjak, 1937; Ali-Zade, 1961; Muratov and Nevesskaya, 1986). In the 1950's - 1970's, magnetostratigraphic analyses in the South Caspian Basin contributed to an age model for the late Pliocene-Pleistocene regional stages of the Caspian region (Khramov, 1960; 1963; Trubikhin, 1977; Pevzner, 1986).

The Lower-Middle Pleistocene geological record of the Caspian region comprises four regional stages: Akchagylian, Apsheronian, Bakunian and Khazarian (Krijgsman et al., 2019). The Akchagylian Stage was defined by Andrusov on the Krasnovodskiy peninsula (Turkmenian coast) and named after the "Akchagyl hill" (Andrusov, 1902; Ali-Zade, 1961; Muratov and Nevesskaya, 1986). The lectostratotype (the Ushak well) is also located on the Krasnovodskiy peninsula in Turkmenistan (Ali-Zade, 1961). In the Kura Basin, the Akchagylian stage developed as a dark grey claystone unit interbedded with white ash layers (van Baak, 2015a). The Akchagylian Stage represents a wide transgression event following the Productive Series lowstand phase. The lake expanded far onto the northern and western margins of the basin and refilled all sub-basins like the Kura Basin, pre-Kopet-Dagh Gulf, Aral Sea, as well as the Volga and Kama deltaic plains (Muratov and Nevesskaya, 1986; Popov et al., 2006). One of the most distinguishing features in the Akchagylian is its unique endemic mollusc fauna (Paramonova, 1994; Danukalova, 1996). Characteristic mollusc species include Cerastoderma dombra, Avimactra subcaspia, Pirenella caspia, as well as species of Aktschagylia, Andrussovicardium, Avicardium and Miricardium (Nevesskaya and Trubikhin, 1984; Paramonova, 1994; Danukalova, 1996). Microfaunas contain oligo- to mesohaline ostracods of Leptocythere, Limnocythere, Loxoconcha, euryhaline Cyprideis and freshwater species of genus Candona. The most common foraminifera taxa are Bolivina, Cassidulina and Cibicides (Rozyeva, 1971; Paramonova, 1994; Alizadeh et al., 2016). During the Akchagylian, a possible connection existed between the Caspian Sea and the Arctic Ocean (Mordukhai-Boltovskoi, 1964; van Baak, 2015a; Richards et al., 2018b). However, the pathways of the connection, as well as the origin of this fauna, are still unclear (Hoyle et al., 2019b; Krijgsman et al., 2019).

The age of the onset of the Akchagylian Stage is still under discussion (Krijgsman et al., 2019). It was commonly correlated to the lower limit of the Gauss chron at 3.6 Ma (Trubikhin, 1977). However, revision of this correlation, as well as recent data from the Kura Basin and Apsheron peninsula, suggest an age of $2.7 \mathrm{Ma}$ instead, which correlates to the upper limit of the Gauss chron (Gurarii, 2015; van Baak, 2015a; Abdullayev et al., 2018; Hoyle et al., 2019b).

The Apsheronian Stage was defined by Barbot-de-Marni and Simonovic (1891) and has been described in more details by Andrusov (1923). The Bayil section near Baku City was proposed as a lectostratotype (Borissjak, 1937; Vereshchagin, 1982; Muratov and Nevesskaya, 1986). In Apsheronian time, the size of the Caspian Sea slightly diminished compared to the previous Akchagylian stage. Apsheronian deposits almost everywhere, conformably overlie Akchagylian deposits (Sidnev, 1985; Zastrozhnov et al., 2013; Alizadeh et al., 2016). 
The Apsheronian mollusc fauna almost entirely replaced the previous Akchagylian communities (Nevesskaya and Trubikhin, 1984). The Apsheronian mollusc fauna is dominated by cardiids, hydrobiids and dreissenids. Among them are bivalve genera Dreissena, Corbicula, Apscheronia, Monodacna, Didacna, Didacnomya and Hyrcania and the gastropod genera Turricaspia, Streptocerella and Lymnaea (Nevesskaya, 1958; Bludorova et al., 1983; Nevesskaya and Trubikhin, 1984; Muratov and Nevesskaya, 1986). Ostracod species of the genera Leptocythere and Caspiolla typify the Apsheronian (Bludorova et al., 1983; Alizadeh et al., 2016). Several of these genera occurred in the Pliocene-Early Pleistocene Black Sea Basin and were absent during the Akchagylian in the Caspian Basin. Therefore, part of the Apsheronian fauna appears to have originated in the Black Sea Basin (Bogachev, 1940; Popov, 1970; Taktakishvili, 1977).

Apsheronian deposits are usually conformably overlain by Middle Pleistocene Bakunian deposits. However, some researchers documented erosive sandy and conglomeratic deposits with freshwater mollusc and ostracod fauna on top of the Apsheronian (Svitoch and Yanina, 2007). These deposits are locally known as Tyurkyanian and represent a lowstand of the Caspian Basin at the end of the Apsheronian stage. The stratigraphic rank of Tyurkyanian is still unclear. It is considered as an independent stage (Svitoch and Yanina, 2007; Zastrozhnov et al., 2013), a suite (Vereshchagin, 1982) or as the lowermost part of Bakunian Stage (Krasnov, 1984). Here, we only focused on the subdivision of the Apsheronian and Bakunian.

The base of the Apsheronian stage is commonly correlated to the top of the Olduvai subchron at the age of 1.8 Ma (Kochegura and Zubakov, 1978; Semenenko and Pevzner, 1979). The polarity pattern of the Duzdag section in Azerbaijan (Pevzner, 1986), however, shows that the onset of the Apsheronian is better correlated to the Reunion subchron, estimated at 2.1 Ma. This provides an alternative correlation for the Akchagylian-Apsheronian transition (see Krijgsman et al., 2019 and references therein).

The Bakunian Stage was defined by Sjögren (1891) on the Absheron Peninsula of Azerbaijan, as sedimentary strata that overlie the Apsheronian deposits (Borissjak, 1937). The Gora Bakinskogo Yarusa section and the Neftyanaya Balka section have been proposed as lectostratotypes (Yanina, 2013).

The Bakunian mollusc fauna is very distinct from the Apsheronian fauna: it is dominated by a set of particular Didacna species. The Bakunian stage is divided into two sub-stages. The lower Bakunian is characterised by a wide range of differently shaped Didacna species, like Didacna parvula and D. catillus catillus. Furthermore, Dreissena rostriformis and ostracods such as Eucypris inflata, Candoniella albicans and Cypris mandelstami (Krasnov, 1984) occur in this interval. The upper Bakunian is represented by Didacna eulachia, D. bakuana, D. rudis, D. carditoides coexisting with the same species occurring in the lower Bakunian (Yanina, 2013). Among typical ostracods are species of the genera Candona, Eucypris, Loxoconcha and Leptocythere (Ali-Zade, 1961; Krasnov, 1984). 
Some researchers also recognise a separate Urundzhikian Stage between the Bakunian and Khazarian (Svitoch et al., 2010; Yanina, 2012; Yanina, 2013). The Urundzhikian stratigraphic status is unclear, as it is considered as a stage, horizon, suite or just as a layer (Krasnov, 1984). The Urundzhikian mollusc association consists of species that are typical for the preceding Bakunian and succeeding Khazarian (Yanina, 2012). Due to all issues mentioned above, we here only use a division into Bakunian and Khazarian.

The base of the Bakunian Stage is correlated to the Matuyama-Brunhes polarity reversal and is dated at $0.781 \mathrm{Ma}$ (Asadullayev and Pevzner, 1973). However, recent studies on the Xocashen section in Azerbaijan suggest a slightly older age of $0.85 \mathrm{Ma}$, corresponding to the upper part of the Matuyama (van Baak et al., 2013). Hence, the base of the Bakunian Stage is estimated between $0.78 \mathrm{Ma}-0.85 \mathrm{Ma}$. In the Goychay area (Fig. 4.1C), the continental Ushtal suite is widely represented by alluvial deposits with a thickness up to $500 \mathrm{~m}$. This is considered to be the terrestrial analogue of Bakunian deposits (Alizadeh et al., 2016).

The Khazarian Stage was defined by Andrusov in 1913 and later clarified as strata that transgressively overlie upper Bakunian and Urundzhikian deposits in the North Caspian Basin and the Manych region (Vereshchagin, 1982). Despite several existing subdivision schemes, we follow here a subdivision into a lower and upper Khazarian that represents two successive transgressive events with different mollusc faunas (Vekilov, 1969). The lower Khazarian is characterised by the abundance of so-called trigonoidal Didacna species, such as Didacna subpyramidata, D. trigonula, D. paleotrigonoides. Furthermore, some species of the catilloidal group with Didacna subcatillus, D. dilatata and the crassoidal group with Didacna nalivkini, $D$. apscheronica, D. pravoslavlevi occur (Yanina, 2012). Among microfauna, most typical ostracods are Candoniella subellipsoida, Caspiolla gracilis, Leptocythere arevina, Loxoconcha endocarpa, Cytherissa cascusa, and key foraminifera are Ammonia caspica and Mayerella brotzkajae (Sedaikin, 1988; Yanko, 1989; Svitoch and Yanina, 1997). In the upper Khazarian, a group of crassoidal Didacna with D. surachanica are indicative species (Fedorov, 1957; Yanina, 2012).

The lower Khazarian is correlated to the upper part of the Middle Pleistocene and dated between 400-260 ka. It shows normal polarities (Brunhes) and one or two short-term reverse polarity fluctuations (Saltykov, 2011). A recent review on the lower Khazarian suggests a correlation to the MIS 10 stage and age around 0.37-0.38 Ma (Saltykov, 2011; Krijgsman et al., 2019).

A brief overview of the regional stratigraphic time scale shows that regional stages are distinct and characterised by specific faunal assemblages. However, there are still many uncertainties regarding the definition and age constraints of the stage boundaries.

\subsection{Material and methods}

The Goychay section $\left(\mathrm{N} 40.684458^{\circ}, \mathrm{E} 47.759803^{\circ}\right)$ is located on the north-western margin of the Kura Basin and was previously described and logged in detail (Forte et al., 2013). A 

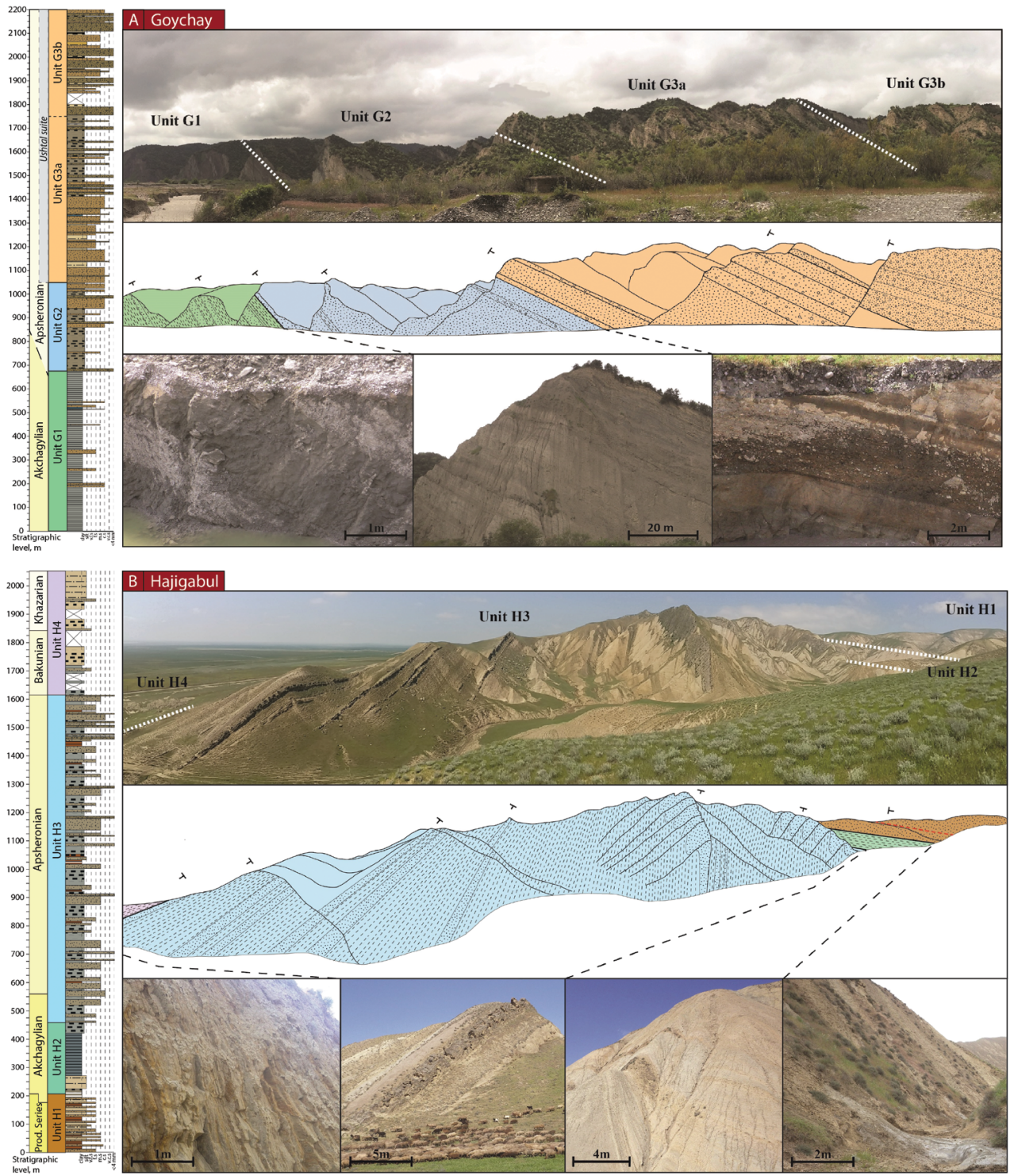

Figure 4.2 Lithostratigraphic subdivision of the Goychay section (A) and the Hajigabul section (B). Logs, general view and characteristic photos of each sedimentary unit.

stratigraphic succession of $2200 \mathrm{~m}$ thick is exposed along the Göy River that flows southwards, cutting through an NW-SE foreland thrust fault system (Fig. 4.1C, 4.2A) (Forte et al., 2013). The Hajigabul section $\left(\mathrm{N} 40.1270332^{\circ}, \mathrm{E} 48.8726990^{\circ}\right.$ ) is located to the Southeast of Goychay, $11 \mathrm{~km} \mathrm{NW}\left(330^{\circ}\right)$ from the Hajigabul city centre (also known as Adzhikabul or Hajiqabul), in a more central and deeper part of the Kura Basin (Fig. 4.1D). The section crops out along 
the Hajigabul anticline, also known as the Maliy Kharami (or Kichik Kharami) fold whose axis trends $320^{\circ} \mathrm{NW}-140^{\circ} \mathrm{SE}$. A well-exposed stratigraphic succession of $2035 \mathrm{~m}$ thick was logged in detail, with GPS coordinates taken at $5 \mathrm{~m}$ stratigraphic intervals (Fig. 4.2B). The interval $1560-1730 \mathrm{~m}$ was additionally studied in a neighbouring valley (Section $\mathrm{B}, \mathrm{N} 40^{\circ} 7^{\prime} 8.00^{\prime \prime}$, E48 $52^{\prime}$ '57.30") due to bad exposure in the main Section A (Fig. 4.1D).

For palaeomagnetic investigations, 142 stratigraphic levels were sampled along the Goychay section and 197 levels along the Hajigabul section. Two standard cylindrical cores were collected from each level using an electric drill with a diamond crone, water pump and electrical generator as power supply. Each core was oriented with a measuring table and compass. A local declination of 60 (https://www.ngdc.noaa.gov) has been added to the orientation measurements to compensate for secular variation.

Palaeomagnetic measurements were performed at the Paleomagnetic Laboratory "Fort Hoofddijk" at Utrecht University, the Netherlands. In total, 218 samples were stepwise thermally demagnetised with increments of $30-40^{\circ} \mathrm{C}$ in zero field magnetic conditions. Natural remanent magnetization (NRM) was measured on a horizontal 2G Enterprises DC SQUID cryogenic magnetometer (noise level $3 \times 10^{-12} \mathrm{Am}^{2}$ ). Each sample was measured in multiple positions and incrementally heated up to a maximum temperature of $680^{\circ} \mathrm{C}$, or to a lower temperature where the remanent magnetization was less than $10 \%$ of the initial NRM. In addition, 23 samples from the Hajigabul section were demagnetised in alternating field (AF) from 0 to 100 $\mathrm{mT}$. Measurements in alternating field (AF) were performed on a robotised sample handler controller attached to a horizontal $2 \mathrm{G}$ Enterprises DC SQUID cryogenic magnetometer (Mullender et al., 2016). Bulk magnetic susceptibility measurements were performed on an AGICO Kappabridge MFK1-FA at room temperature and applied field of $200 \mathrm{~A} / \mathrm{m}$. To identify magnetic carriers, ten samples from both sections were measured for thermomagnetic properties in air on a horizontal type Curie balance (noise level $5 \times 10^{-9} \mathrm{Am}^{2}$ ) (Mullender et al., 1993). Interpretation of measured directions was carried out using the online platform Paleomagnetism.org (Koymans et al., 2016). The supplementary material files associated with this paper contain a catalogue with information about all taken and analysed samples (Supplementary 1,2) as well as interpretation of palaeomagnetic data (directions and statistics) that can be uploaded on Paleomagnetism.org (Supplementary 3-8).

In our paper, we refer to the Geomagnetic Polarity Time Scale (GPTS) 2012 (Hilgen et al., 2012) for the correlation of magnetic polarity patterns. We also used the last improvement on the age of the Cobb Mountain subchron (Channell, 2017). For the calculation of sedimentation rates, we used the ratio of the thickness of polarity intervals in the section to the actual duration of the corresponding chron in GTS2012. The boundary between normal and reversed intervals has been set at the middle point between two measured samples with different polarity. Uncertainty levels were calculated by assuming the upper- and lowermost possible stratigraphic 
position of the polarity zone. For incomplete chrons, we extrapolate sedimentation rate from the underlying, relatively long, complete chrons with similar lithology/depositional environments.

For the micropalaeontological study, 46 samples from Goychay and 57 samples from Hajigabul section have been analysed for ostracods and foraminifera. Samples were processed using a standard micropalaeontological approach, sieved over $63 \mu \mathrm{m}$ sieves and handpicked under a microscope following procedures outlined in Stoica et al. (2013). We also studied the fossil mollusc assemblages in both sections by making field observations and taking hand samples. In total, ten samples in Goychay and 61 samples in Hajigabul have been analysed for mollusc fauna. These samples were typically $0.5-1 \mathrm{~kg}$ and were washed over $1 \mathrm{~mm}$ sieves and picked. For identifications, Andrusov (1923) and Kolesnikov (1950) have been used. For estimation of water salinity, we used three salinity intervals from the Venetian classification: freshwater (0-0.5\%o), oligohaline (0.5-5\%o) and mesohaline (5-18\%o).

\subsection{Results}

\subsubsection{Goychay section}

\subsubsection{Lithological description}

The Goychay section has been subdivided into three depositional units (Fig. 4.2A). Unit G1 $(0-675 \mathrm{~m})$ represents a thick clay-dominated interval at the base of the section. The lowermost part of Unit G1 $(0-120 \mathrm{~m})$ is represented by thinly laminated grey claystones. Higher in the section, grey claystones alternate with rare centimetre-scale layers of brownish siltstones and coarse sandstones. The sandstones display millimetre-scale horizontal laminae and centimetrescale wavy bedding, sigmoidal cross-stratification and centimetre-scale scours. These sedimentary structures are often separated by dark-grey organic-rich clay partings. Locally, centimetre-scale soft-sediment deformation structures are present. In addition, we observed a few levels rich in molluscs. Unit G1 is interpreted as a distal depositional environment with claystones deposited out of suspension, occasionally disrupted by sandstones transported by small density underflow currents into open-waters. Towards the top of Unit G1, sandstone layers become coarser and more frequent, indicating a regressive/prograding trend.

Unit G2 $(675-1050 \mathrm{~m})$ is composed of brownish-grey mudstones recurrently alternating with yellowish-brown siltstones and conglomeratic sandstones (Fig. 4.2A). Its lower boundary is marked by the appearance of the first conglomeratic layer. Sandstones are deposited in meter- to decametre-thick beds, which often display an erosive base. These beds include decimetre- to meter-scale sigmoidal cross-stratification, decimetre-scale scours and millimetrescale horizontal laminations. Sedimentary structures are typically separated by finer-grained sandstones or by dark-grey organic-rich clay partings. Some anomalohaline (brackish) and freshwater mollusc species were found in these deposits. Unit G2 records sediments deposited 
out of suspension, frequently disturbed by large density underflow currents. This interval was subject to higher energy outflows in a more proximal depositional environment compared to Unit G1. The sedimentary succession displays coarser and thicker sandstone beds towards the top, representing a regressive/prograding trend.

Unit G3 can be subdivided into two subunits. The subunit G3a (1050-1750 m) consists of brownish fine to conglomeratic sandstones, deposited in meter- to decametre-thick erosive layers (Fig. 4.2A). Its lower boundary is defined by the disappearance of distal claystones. Sandstone layers often contain lag deposits at their base with normal grading and meterscale sigmoidal cross-stratification. Sedimentary structures are typically separated by finer grained sandstone partings. Sandstone beds usually form decimetre-wide channels. They are intercalated with yellowish-brown mudstones and siltstones. Unit G3a is interpreted as being deposited in fluvial environments.

The subunit G3b (1750-2200 m) consists of conglomeratic beds interbedded with dark grey and reddish-brown claystones. Dark grey claystones contain abundant millimetre- to centimetre-scale organic fragments. They include centimetre-scale vertical roots and contain some centimetre-thick coal layers, as well as terrestrial flat gastropods. The sandstones were deposited under very high energies in fluvial channels. In between these fluvial channels, organic-rich fine-grained sediments were deposited out of suspension in flood plains. Thereby, subunit G3b was deposited in subaerially exposed setting of fluvial and floodplain environments. The general sedimentary succession recorded along the Goychay section thus highlights a regressional trend from distal open-water to proximal fluvial and floodplain depositional environments.

\subsubsection{Microfauna (ostracods and foraminifera)}

Throughout the Goychay section, several ostracod assemblages have been identified, representing frequent variations between freshwater, oligohaline and mesohaline environments. The lowermost part of Unit G1 $(77.5-99.4 \mathrm{~m})$ is dominated by mesohaline assemblages with the foraminifera Ammonia sp. and ostracods like Loxoconcha eichwaldi, L. petasa, L. babazananica, Eucythere naphtatscholana, Tyrrhenocythere bailovi, Amnicythere ex. gr. andrussovi, A. cymbula, A. monotuberculata, A. alveotuberculata, Cyprideis torosa and Cytherissa bogatschovi (Fig. 4.3). Higher in the section, foraminifera disappear, and the ostracod assemblages reduce in the number of taxa, suggesting oligohaline environments (Fig. 4.3). Samples between 267-285 $\mathrm{m}$ are barren in microfauna. After this barren zone, the diverse anomalohaline ostracod assemblages alternate with short intervals that contain exclusively freshwater species. Freshwater assemblages include mainly Ilyocypris bradyi and Candona sp. (fragments and juveniles) and charophytic gyrogonites. In the upper part of Unit G1, at 651 $\mathrm{m}$, abundant populations of Cyprideis torosa and Tyrrhenocythere azerbaijanica characterize levels with elevated (oligohaline) salinities. In addition, the anomalohaline species Amnicythere 
multituberculata, Leptocythere gubkini, Candona cambibo and Camptocypria acronasuta are present. This assemblage continues at the base of Unit G2 (700 m, $703.5 \mathrm{~m})$.

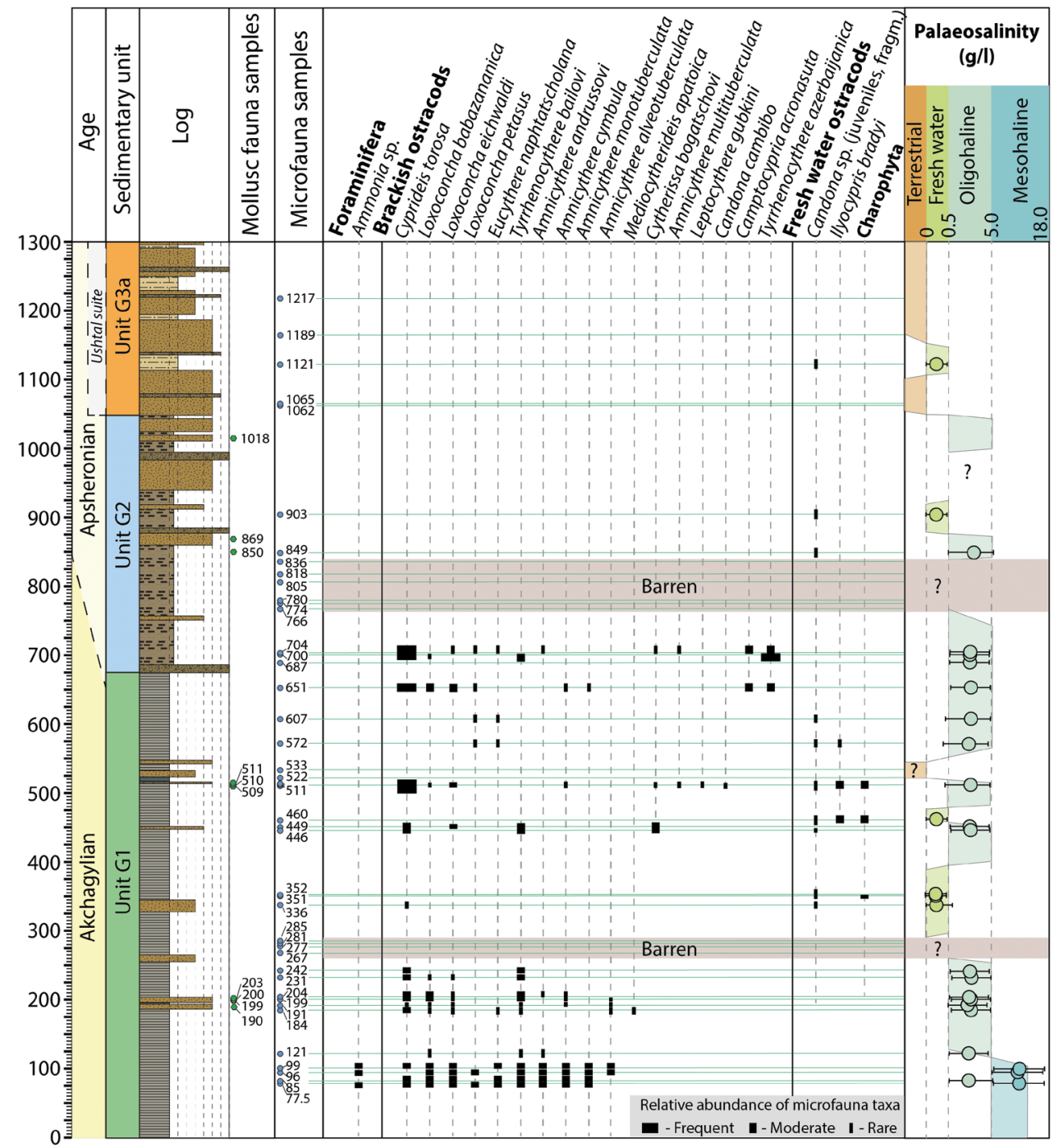

Figure 4.3 Sedimentary log, palaeontological sampling points, microfauna assemblages and palaeosalinity estimation in the Goychay section.

The major part of Unit G2 generally lacks microfauna. Exceptions are the short intervals between $849-903 \mathrm{~m}$ that contain rare and poorly preserved candonids, together with mollusc fauna suggesting freshwater to oligohaline environments. 
Subunit G3a also lacks microfauna and only in one sample $(1121 \mathrm{~m})$ did we discover poorly preserved candonids that indicate freshwater environments (Fig. 4.3). Thereby, the micropalaeontological record of the Goychay section displays a gradual transition from mesohaline to freshwater assemblages towards the top, which is in a good agreement with the regressive trend observed in sedimentary facies.

The abundant ostracod fauna in the Goychay section resembles Akchagylian-Apsheronian ostracod assemblages described in other sections across the Kura Basin (Richards et al., 2018b; Krijgsman et al., 2019; van Baak et al., 2019).

\subsubsection{Macrofauna (molluscs)}

Along the Goychay section, ten samples were analysed covering the interval $189-883 \mathrm{~m}$ (Table 4.1). These samples are from Unit G1 (samples GOY-M-01 - GOY-M-07) and from Unit G2 (samples GOY-M-08 to GOY-M-10). The fluvial environment of subunit G3a contains very few molluscs, but some terrestrial gastropod species have been recorded there (Forte et al., 2013). In general, the studied mollusc assemblages seem to be in situ, marked by the presence of paired bivalves, and often show excellent preservation of gastropods and bivalves. In samples GOY-M-01 (189.5 m), GOY-M-06 (511.3 m), GOY-M-08 (849.3 m) and GOY-M-09 $(868.6 \mathrm{~m})$, rare indications of reworking are present (differences in colouration and abrasion). Samples GOY-M-02 (199 m), GOY-M-03 (200 m), GOY-M-04 (203 m) contain well-preserved shells, nevertheless demonstrating features of downslope transportation (irregular distribution in turbidite layers). Compaction (cracking) is common in several samples, as is some postdepositional dissolution.

Samples GOY-M-01 to GOY-M-04 are dominated by Laevicaspia, Turricaspia and Theodoxus gastropod species, and Dreissena and Corbicula bivalve species (Fig. 4.4, 4.5). This assemblage resembles somewhat the modern oligohaline Caspian Sea faunas with the exception of Corbicula that is restricted to rivers today. Sample GOY-M-02, dominated by Theodoxus, indicates vegetated seafloor at shallow depth. In sample GOY-M-05 (510.3 m) Lymnaeidae and Valvata frequently occur. It also contains a few Melanopsis individuals, Bithynia fragments and an operculum. Together with the abundant charophytes, we interpret this as a freshwater assemblage. Samples GOY-M-06 and GOY-M-07 are dominated by a mixture of Corbicula, dreissenids and abundant hydrobiids, likely representing freshwater to oligohaline conditions. In samples GOY-M-08 to GOY-M-10, Lymnocardiinae species are common, as well as hydrobiids and some dreissenids. They all contain the Apsheronian gastropod Caspia apscheronica. In general, the upper three samples reflect more oligohaline to mesohaline shallow lake conditions.

Indicative Akchagylian mollusc groups such as Avimactra, Pirenella and endemic lymnocardiine genera (Andrusov, 1923; Kolesnikov, 1950) are absent in the Goychay section. In samples GOY-M-01 to GOY-M-07, we observe low oligohaline assemblages that are common 


\begin{tabular}{|c|c|c|c|c|c|c|c|c|c|c|c|c|c|c|c|c|c|c|c|c|c|c|}
\hline \multirow[b]{2}{*}{ 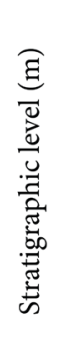 } & \multirow[b]{2}{*}{ 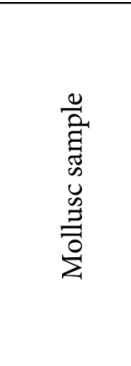 } & \multicolumn{18}{|c|}{ Molluscs } & \multicolumn{3}{|c|}{ Palaeosalinity } \\
\hline & & 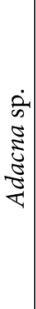 & 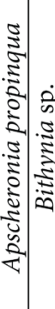 & 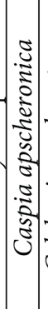 & 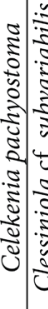 & 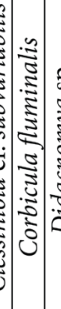 & 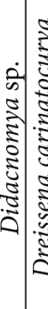 & 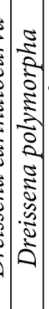 & 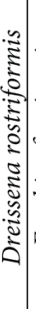 & 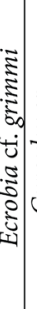 & 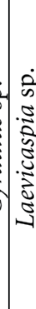 & 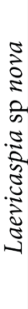 & 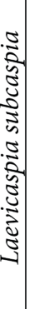 & 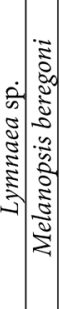 & 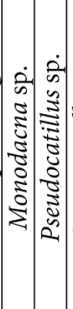 & & 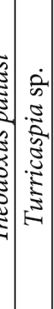 & 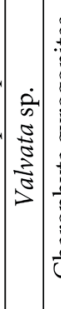 & 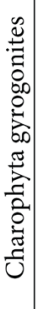 & 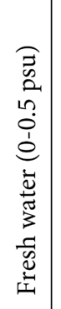 & 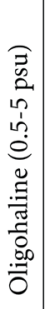 & 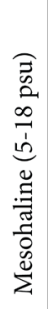 \\
\hline 1018 & $\begin{array}{l}\text { GOY-M- } \\
10\end{array}$ & 2 & & 1 & & 1 & 3 & 1 & 1 & & & & & & & & & & & & $\mathrm{X}$ & $\mathrm{X}$ \\
\hline 868 & $\begin{array}{l}\text { GOY-M- } \\
09\end{array}$ & & 1 & 1 & & & 2 & & 3 & & 3 & 1 & 3 & & 1 & 1 & 1 & & & & $\mathrm{X}$ & $\mathrm{X}$ \\
\hline 849 & $\begin{array}{l}\text { GOY-M- } \\
08\end{array}$ & & 2 & 2 & 1 & & 1 & 2 & 3 & 1 & 2 & 3 & 2 & 2 & 2 & 2 & 2 & & & $\mathrm{X}$ & $\mathrm{X}$ & $\mathrm{X}$ \\
\hline 511 & $\begin{array}{l}\text { GOY-M- } \\
07\end{array}$ & & & & & 2 & & 2 & & & 2 & & 2 & & & & & & & $\mathrm{X}$ & $\mathrm{X}$ & ? \\
\hline 510 & $\begin{array}{l}\text { GOY-M- } \\
06\end{array}$ & & & 1 & & 3 & & 2 & & & 2 & & 2 & & & \begin{tabular}{l|l|l}
1 & 1
\end{tabular} & 1 & 2 & & $\mathrm{X}$ & $\mathrm{X}$ & \\
\hline 509 & $\begin{array}{l}\text { GOY-M- } \\
05\end{array}$ & & 1 & & 1 & & & & & & & & & \begin{tabular}{l|l|l}
2 & 1
\end{tabular} & & & & 2 & 3 & $\mathrm{X}$ & & \\
\hline 203 & $\begin{array}{l}\text { GOY-M- } \\
04\end{array}$ & & & & 1 & & & 3 & & & 1 & & 3 & & & & 3 & & & & $\mathrm{X}$ & \\
\hline 200 & $\begin{array}{l}\text { GOY-M- } \\
03\end{array}$ & & & & 1 & 1 & & & 1 & & 3 & & 3 & & & & 3 & & & & $\mathrm{X}$ & $?$ \\
\hline 199 & $\begin{array}{l}\text { GOY-M- } \\
02\end{array}$ & & & & 1 & & & & 2 & 1 & & & & & & & \begin{tabular}{l|l|}
3 & 2 \\
\end{tabular} & & & & $\mathrm{X}$ & \\
\hline 190 & $\begin{array}{l}\text { GOY-M- } \\
01\end{array}$ & & & & 1 & 1 & & & 2 & & 2 & & 3 & & & & 2 & & & & $\mathrm{X}$ & $?$ \\
\hline \multicolumn{23}{|c|}{ Abundance } \\
\hline 1 & rare & \multicolumn{6}{|c|}{$1-10$ individuals } & & & & & & & & & & & & & & & \\
\hline 2 & moderate & \multicolumn{6}{|c|}{$11-30$ individuals } & & & & & & & & & & & & & & & \\
\hline 3 & frequent & \multicolumn{6}{|c|}{$>30$ individuals } & & & & & & & & & & & & & & & \\
\hline
\end{tabular}

Table 4.1 Distribution of mollusc taxa in the Goychay section.

in the Apsheronian (Table 4.1, Fig. 4.5). Occurring species are Laevicaspia subcaspia, Celekenia pachyostoma and thin elongated egg-shaped Caspia species (Caspia matura and C. apsheronica as illustrated in Kolesnikov 1950). Starting from 849 m (samples GOY-M-08 to GOY-M-10) the indicative Apsheronian bivalve taxa Apscheronia propinqua s.l. and Monodacna sp. are present (Table 4.1, Fig. 4.4).

\subsubsection{Palaeomagnetic results}

The thermal demagnetization of samples from the Goychay section revealed two NRM components. The first is a low-temperature component of normal polarity (LT_N) that becomes 


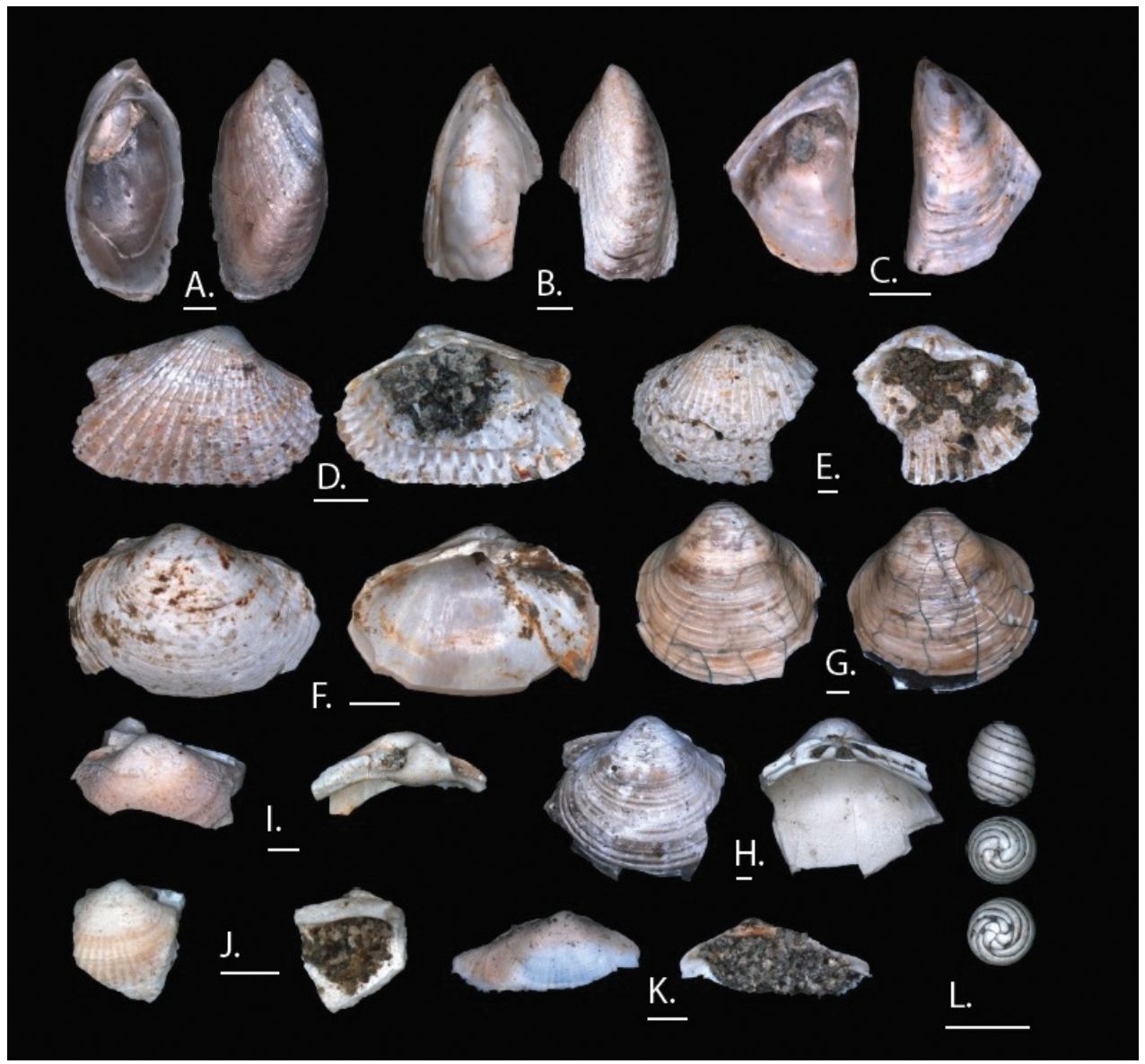

Figure 4.4 Selected bivalve species and charophyta from the Goychay section: A. Dreissena carinatocurva; B. Dreissena rostriformis; C. Dreissena polymorpha; D. Pseudocatillus sp.; E. Didacnomya sp.; F. Apscheronia propinqua; G. Corbicula fluminea (paired bivalve); H. Corbicula fluminea; I. Monodacna sp. 1; J. Monodacna sp. 1; K. Adacna sp; L. Oogonium of charophyta. (Scale bars $1 \mathrm{~mm}$ ).

fully demagnetised at temperatures of $250-300^{\circ} \mathrm{C}$ (Fig. 4.6A). Within a set of 84 samples from this section, $40 \%$ have a weak LT_N component that is fully demagnetised at $180^{\circ} \mathrm{C}$, whereas $30 \%$ lack this component. The mean direction of the LT_N component has parameters of D $=5.9^{\circ}, \mathrm{I}=41.1^{\circ}, \mathrm{k}=10.8$, a95 $=6.6$ for $\mathrm{N}=47$ samples (Fig. 4.6B). The LT_N component is considered a present-day overprint, even though the inclination values are aberrantly low. The magnetic field estimated values for the Goychay district are $\mathrm{D}=6.13^{\circ}, \mathrm{I}=59.4^{\circ}$ (https://www. ngdc.noaa.gov, May 2016).

The average inclination values of the LT_N component are $18^{\circ}$ lower than the expected present-day field value. The equal area plot shows that all low-temperature directions form two 


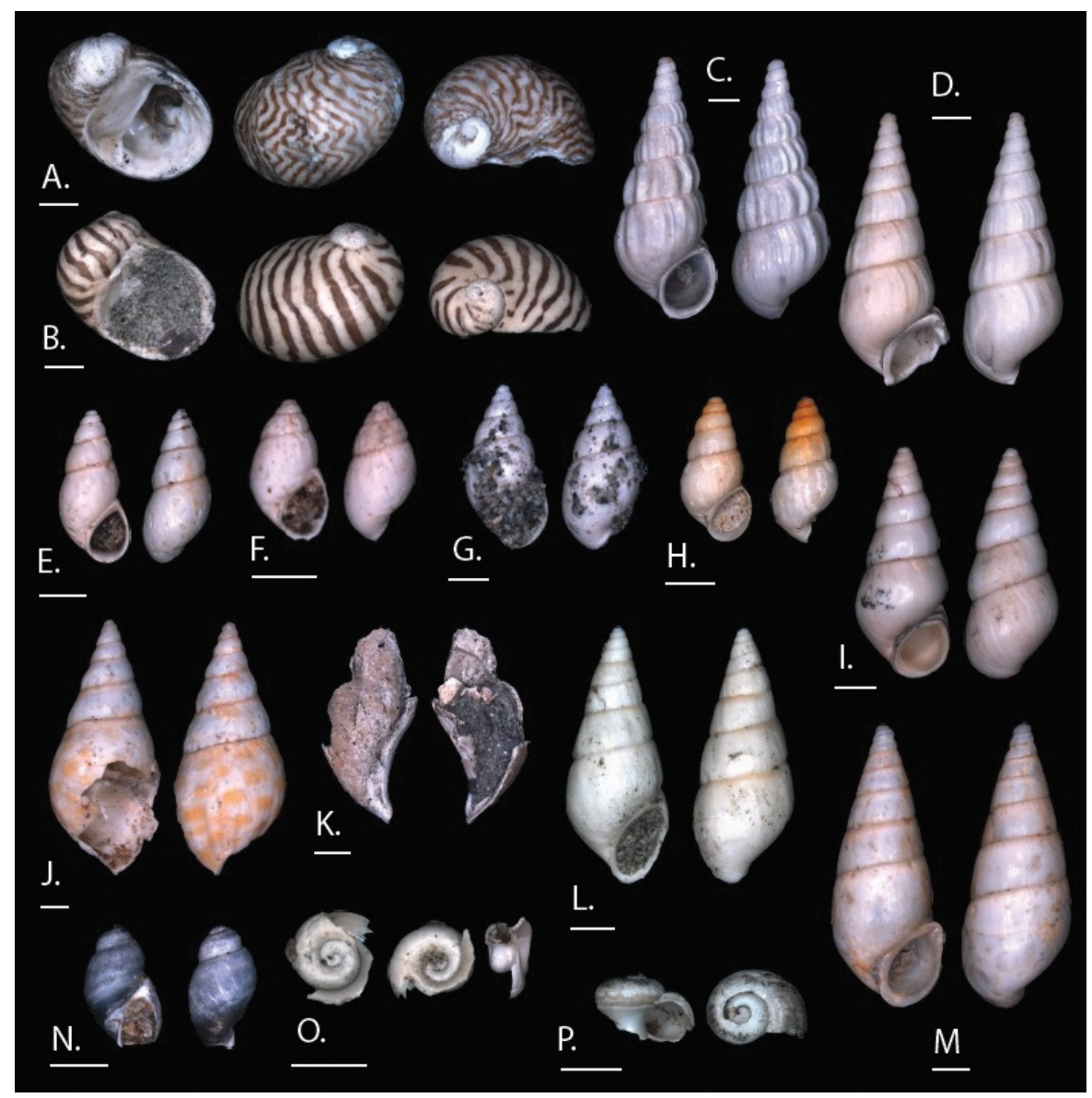

Figure 4.5 Selected gastropods from the Goychay section. A. Theodoxus pallasi; B. Theodoxus pallasi; C. Laevicaspia sp. D. Laevicaspia subcaspia; E. Caspia apsheronica; F. Caspia sp.; G. Clessiniola cf. subvariabilis; H. Ecrobia cf. grimmi; I. Laevicaspia subcaspia; J. Melanopsis bergeroni; K. Lymnaea sp.; L. Turricaspia sp. ; M. Laevicaspia sp.; N. Streptocerella sp.; O. Gyraulus sp.; P. Valvata sp. (Scale bars $1 \mathrm{~mm}$ ).

clouds - one around the current day magnetic overprint and the second widely dispersed. The isolation of the first cloud revealed parameters of $\mathrm{D}=8^{\circ}, \mathrm{I}=51.4^{\circ}, \mathrm{k}=46.7$, a95 $=4.5$ for $\mathrm{N}=23$ samples (Fig. 4.6C). These values are closer to the parameters of the present-day magnetic field in the Goychay district and may be considered as viscous present-day overprints. The second group of random directions is possibly represented by another viscous remanent magnetization.

The second component is further subdivided into two groups: a medium temperature component (MT_R) with a demagnetization temperature range $300^{\circ}-400^{\circ} \mathrm{C}$ (Fig. 4.6D) and a high-temperature component (HT_N, HT_R) with a maximum demagnetization temperature up to $680^{\circ} \mathrm{C}$ (Fig. $4.6 \mathrm{G}, \mathrm{H}$ ). Both (medium and high) decay towards the origin. Samples 


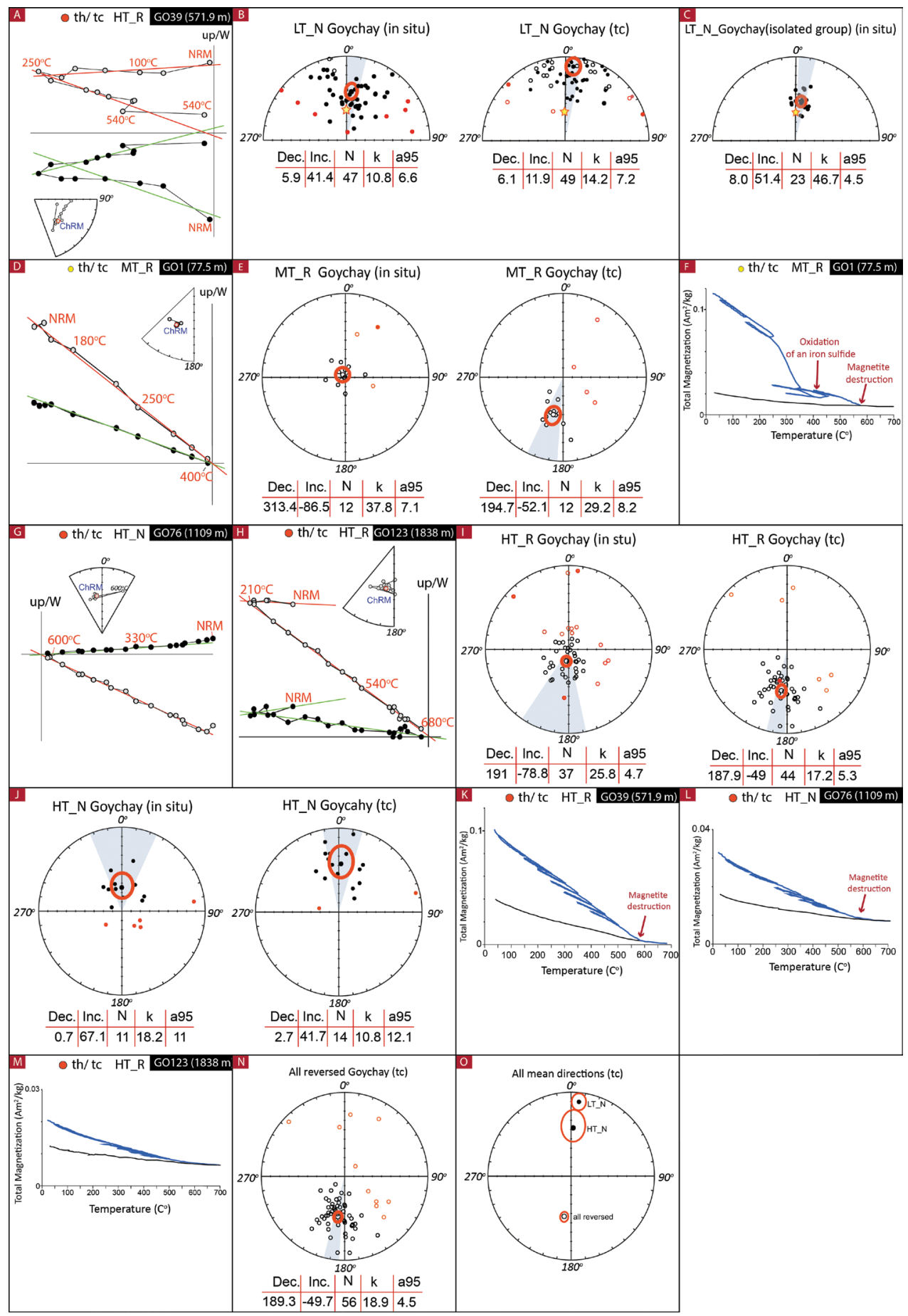


Figure 4.6 (previous page) Equal area plots, Zijderveld diagrams and thermomagnetic curves for samples from the Goychay section. Equal area plots for: B. The low temperature component $\left(20^{\circ} \mathrm{C}-300^{\circ} \mathrm{C}\right.$, LT_N): all LT_N direction in situ and in tectonic coordinates; C. Isolated group of LT_N directions; E. The medium temperature component with reversed directions $\left(330^{\circ} \mathrm{C}-400^{\circ} \mathrm{C}, \mathrm{MT} \_\mathrm{R}\right)$, in situ and in tectonic coordinates (tc); I. High-temperature component $\left(440^{\circ} \mathrm{C}-580^{\circ} \mathrm{C}\left(670^{\circ} \mathrm{C}\right)\right.$, HT_R $)$ with reversed directions, in situ and in tectonic coordinates (tc); J. High-temperature component $\left(440^{\circ} \mathrm{C}-\right.$ $\left.580^{\circ} \mathrm{C}\left(670^{\circ} \mathrm{C}\right), \mathrm{HT} \_\mathrm{N}\right)$ with normal directions, in situ and in tectonic coordinates (tc); N. All reversed direction (MT_R and HT_R) in tectonic coordinates; O. All mean directions for all reversed (MT_R and HT_R), LT_N and HT_N groups; A, D, G and H - characteristic Zijderveld diagrams; F, K, L and M characteristic thermomagnetic runs for various samples.

with a MT component constitute about $20 \%$ of all measured samples and are characterised by a reversed signal. The mean direction of the MT_R component has parameters $\mathrm{D}=$ $194.7^{\circ}, \mathrm{I}=-52.1^{\circ}, \mathrm{k}=29.2$, a95 $=8.2$ for $\mathrm{N}=12$ samples in tectonic coordinates (Fig. 4.6E). Thermomagnetic runs of the sample GO1 show an abrupt magnetization decrease down to 340 $350^{\circ} \mathrm{C}$ with irreversible magnetization loss while cooling is applied (Fig. 4.6F). This signature is typical for greigite (Vasiliev et al., 2008). After the drop, a small peak forms between $400-580^{\circ} \mathrm{C}$ (Fig. 4.6F) that is characteristic for the presence of pyrite (Palcu et al., 2019a). Therefore, in the basal part of the Goychay section, the iron sulphide greigite is considered the main magnetic carrier.

The mean direction of the high temperature reversed group (HT_R) has parameters of $\mathrm{D}=187.9^{\circ}, \mathrm{I}=-49^{\circ}, \mathrm{k}=17.2$, a95 $=5.3$ for $\mathrm{N}=44$ samples in tectonic coordinates, whereas the normal group (HT_N) mean direction is $\mathrm{D}=2.9^{\circ}, \mathrm{I}=41.7^{\circ}, \mathrm{k}=11.7$, a95 $=12.1$ for $\mathrm{N}$ $=14$ samples (Fig. 4.6I, J). Thermomagnetic runs for samples GO39 and GO76 demonstrate a gradual decrease of magnetization down to $580^{\circ} \mathrm{C}$ (Fig. $4.6 \mathrm{~K}, 4.6 \mathrm{~L}$ ). This signature is characteristic for the iron oxide - magnetite - the main magnetic carrier in these samples. Some samples demonstrate a stable signal that continues decaying towards the origin until $670-680^{\circ}$ $\mathrm{C}$ (Fig. 4.6H). They turn red-coloured while being heated. We interpret this magnetic carrier as hematite, even though it is not expressed on the thermomagnetic curves (Fig. 4.6M), due to weaker remanence of hematite compare to magnetite remanence (Dunlop and Ozdemir, 1997). The similarity of the HT_R and MT_R directions indicates that they represent the same magnetic direction. We combine the reversed direction of the two groups under the name "all reversed" (Fig. 4.6N). The reversal test of McFadden and McElhinny (1990) for the group MT_R and HT_R (all reversed) and HT_N is positive (Fig. 4.6O). Therefore, the second magnetic component (MT_R, HT_R, HT_N) is interpreted as being characteristic of the sedimentation age (ChRM).

The Goychay section is dominated by a reversed polarity (reversed zones R1, R2, R3 and R4) with two relatively short normal polarity intervals in the lower (N1: 612-638 m) and the 
upper part (N3: 2091-2112 m) and one long normal interval in the middle (N2: 889-1148 m) (Fig. 4.7). A bulk magnetic susceptibility analysis performed for all measured samples shows

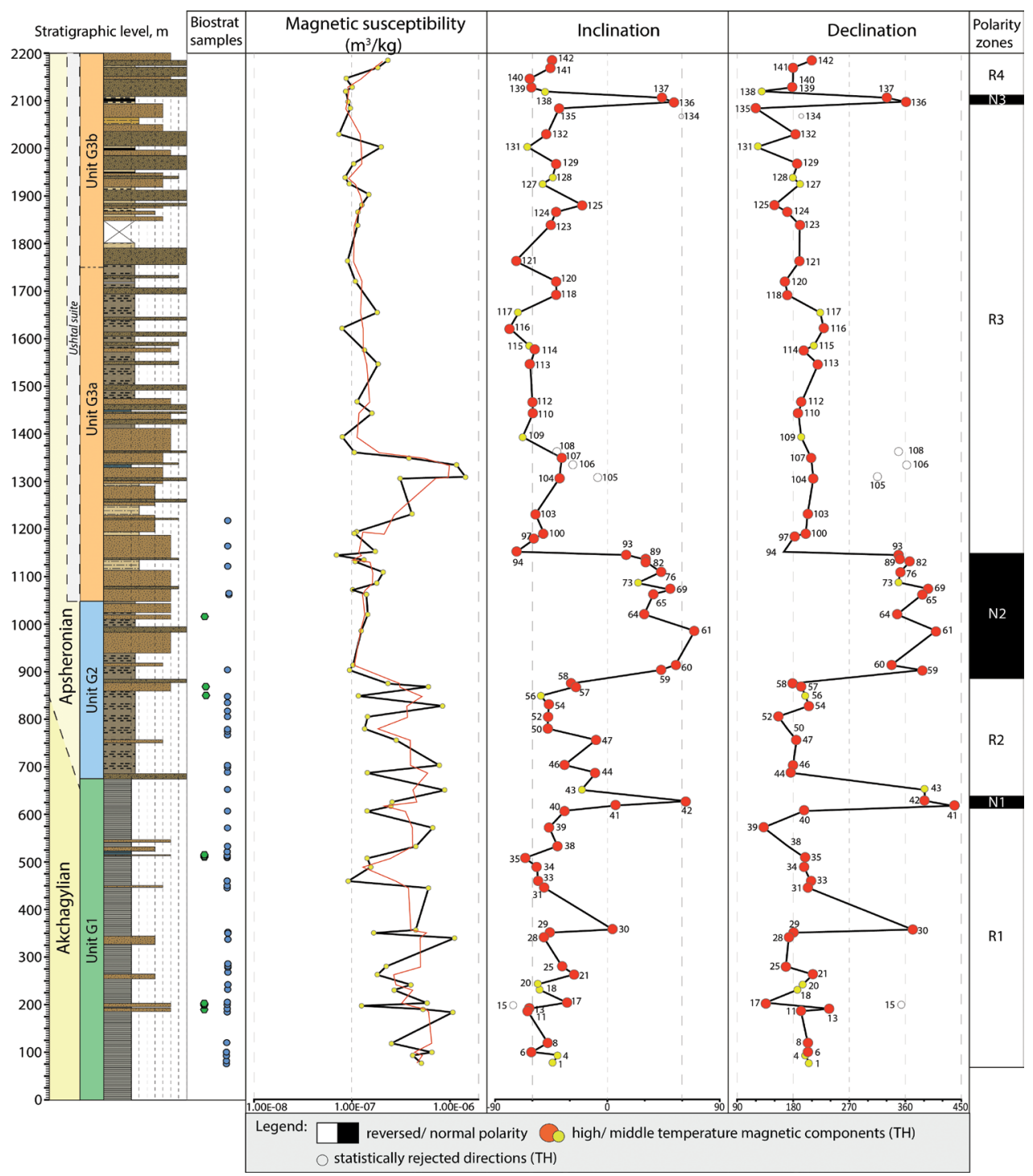

Figure 4.7 Magnetostratigraphy of the Goychay section. In columns, from left to right: Regional (local) stages; Depositional units; Lithological log; Biostratigraphic sampling points: green - mollusc samples, blue - microfauna samples; Magnetic susceptibility (plotted on a logarithmic scale; black line - values for each sample, red line - averaged 3); Inclination; Declination; Interpreted polarity (black - normal, white - reversed). The Akchagylian - Apsheronian transition is drawn based on microfauna (lower limit) and macrofauna (upper limit). 
highly fluctuating values in the lower fine-grained units. After $1400 \mathrm{~m}$, the values stabilize at about 1.00E-07 (Fig. 4.7).

\subsubsection{Hajigabul section}

\subsubsection{Lithological description}

The sedimentary succession of the Hajigabul section can be divided into four main sedimentary units (Fig. 4.2B). Unit H1 $(0-205 \mathrm{~m})$ is mostly composed of brownish fine to coarse sandstones, deposited in centimetre- to meter-thick erosive layers. Sandstone beds display normal-grading, centimetre- to decimetre-scale sigmoidal cross-stratification, centimetre- to decimetre-scale trough cross-stratification and millimetre-scale horizontal laminations. Sedimentary structures are typically separated by finer-grained sandstone or by dark-grey organic-rich clay partings. Sandstone layers alternate with yellowish-brown and reddish claystones and siltstones. These finer deposits contain millimetre- to centimetre-scale organic material fragments and contain some centimetre-scale vertical burrows. Claystones occasionally display slickensides, centimetre-scale vertical rootlets and contain some rare flat terrestrial gastropod shells. The interval below the boundary between Unit H1 and Unit H2 displays several ash layers. Unit $\mathrm{H} 1$ is interpreted to be deposited in fluvial environments. The organic-rich fine sediments were deposited out of suspension on floodplain and later pedogenically modified. Thereby, Unit $\mathrm{H} 1$ was formed in a terrestrial, floodplain and fluvial depositional environments.

The base of Unit H2 $(205-457 \mathrm{~m})$ is marked by the abrupt transition to dark-grey mudstones that overly sandstones from the previous Unit H1 (Fig. 4.2B). These fine-grained deposits contain millimetre-scale horizontal lamination, made of brownish-grey mudstones and siltstones. Some anomalohaline molluscs are found in these deposits including paired lymnocardiine bivalves. Clay-dominated sediments recorded in Unit $\mathrm{H} 2$ were deposited out of suspension in distal open-water environments, which implies a major transgressive phase following Unit $\mathrm{H} 1$.

Unit H3 (457-1614 m) records an alternation between fine and coarse sediments. The previously described dark-grey mudstones are repetitively intercalated with fine to coarsegrained brownish sandstones, and with greenish and reddish claystones (Fig. 4.2B). The sandstones are deposited in centimetre- to decametre-thick layers. They display normal grading, centimetre- to meter-scale sigmoidal cross-stratification, centimetre- to decimetrescale trough cross-stratification, millimetre-scale horizontal laminations, centimetre- to decimetre-scale scours and centimetre- to decimetre-scale hummocky cross-stratification. These sandstones are interpreted to to deposit in nearshore environments. Towards the top of Unit H3, decimetre-scale low-angle cross-stratification and wavy-bedding become common, suggesting lateral move towards coastal depositional environments. Unit $\mathrm{H} 3$ also contains 
some centimetre- to decimetre-thick layers of greenish and reddish claystones. These claystones display slickenslides and contain plant debris, freshwater molluscs and centimetre-scale vertical burrows. We interpret this claystones to be formed in lagoonal and terrestrial environments. Overall, Unit $\mathrm{H} 3$ shows frequent oscillations between distal claystones deposited in open-water environments, proximal sandstones deposited in nearshore and coastal environments and greenish and reddish claystones deposited in lagoons and terrestrial settings. Unit $\mathrm{H} 3$ represents a regression phase following the Unit $\mathrm{H} 2$, and recording repetitive lake-level oscillations.

Unit H4 (1614-2050 m) consists of yellowish-grey claystones and siltstones. Towards the top, they are frequently interbedded with brownish siltstones to fine sandstones, deposited in millimetre- to decimetre-thick layers (Fig. 4.2B). These sandstones present centimetre-scale sigmoidal cross-stratification, centimetre-scale trough cross-stratification, millimetre-scale horizontal lamination and centimetre-scale scours. The claystone- and siltstone-dominated Unit H4 is interpreted to be deposited out of suspension in nearshore environments, repeatedly disrupted by small, density underflow currents in the upper part of this interval. The boundary between Units $\mathrm{H} 3$ and $\mathrm{H} 4$ denotes a major transgressive event.

\subsubsection{Microfauna (ostracods and foraminifera)}

Throughout the Hajigabul section, several assemblages have been identified, representing frequent variations between freshwater, oligohaline and mesohaline environments (Fig. 4.8). Unit H1 (at $110 \mathrm{~m}$ ) contains only freshwater ostracods. Most common taxa are represented by cyprinid ostracod species such as Candona elongata, Candona sp. (the majority poorly preserved or in juvenile stages), Eucypris sp., Cypris subglobosa, Ilyocypris bradyi and Darwinula stevensoni. Similar assemblages have previously been reported from fine-grained, lacustrine intercalations within the Productive Series of the South Caspian Basin (van Baak et al., 2013).

The base of Unit $\mathrm{H} 2(211-453 \mathrm{~m})$ contains an oligohaline assemblage replacing the previous freshwater one (Fig. 4.8). Ostracods in this interval are moderately abundant and taxonomically diverse. Most common taxa include Limnocythere alveolata, L. luculenta, Eucythere naphtatscholana, loxoconchid species represented by Loxoconcha eichwaldi, L. petasa and L. babazananica as well as numerous leptocytherids represented by Leptocythere gubkini, Amnicythere ex. gr. andrussovi, A. nata, A. multituberculata, A. cymbula and Euxinocythere praebosqueti. Two candonid ostracod species are observed: C. candida and Camptocypria acronasuta. Less frequently occurring taxa are Mediocytherideis apatoica, Tyrrhenocythere bailovi and Cytherissa bogatschovi. The faunal composition within unit $\mathrm{H} 2$ is consistent and only shows a barren interval between the stratigraphic levels $427 \mathrm{~m}-543 \mathrm{~m}$. The disappearance may suggest the presence of poorly oxygenated water.

Unit H3 (453-1614 m) contains more diverse ostracod assemblages. At $543 \mathrm{~m}$, a re-established microfauna resembles the same groups as those before the barren zone. Among them are rare ostracods of Eucythere naphtatscholana, Cytherissa bogatschovi and Camptocypria 


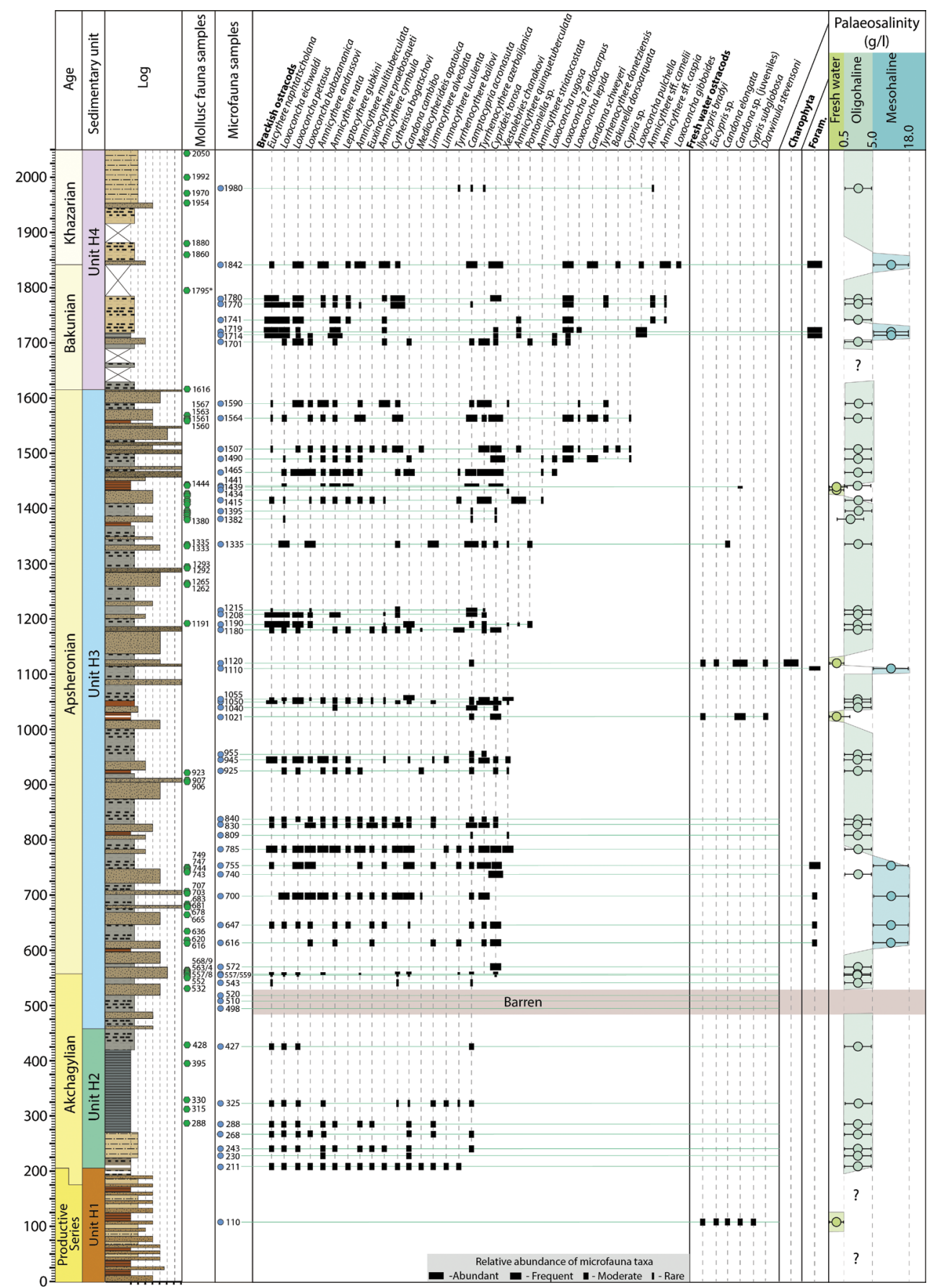

Figure 4.8 Sedimentary log, palaeontological sampling points, microfauna assemblages and palaeosalinity estimation in the Hajigabul section. 
acronasuta (Fig. 4.8). In the interval $616-755 \mathrm{~m}$, ostracod fauna demonstrates quantitative increase of previously presented groups as well as two new taxa - Tyrrhenocythere azerbaijanica and Cyprideis torosa occur. Moreover, this interval is rich in foraminifera - Ammonia, Cibicides and Cassidulina that points at a higher, mesohaline level of salinity (Fig. 4.8). After this interval with higher salinity, the disappearance of foraminifera suggests a reduction of salinity, and ostracod fauna consists of oligohaline assemblages alternating with a few freshwater intervals (755-1701 m). Here, oligohaline assemblages include Cyprideis torosa, Tyrrhenocythere azerbaijanica, and Xestoleberis chanakovi.

At $1110 \mathrm{~m}$, there is a level rich in foraminifera like Ammonia sp., Cassidulina sp. and Porosononion sp. It might indicate a short salinity incursion, caused by an influx of marine water. Between 1465 and $1490 \mathrm{~m}$, a remarkable occurrence of seven new taxa in addition to previous assemblage was revealed: Loxoconcha rugosa, L. lepida, L. endocarpus ?, Candona schweyeri, Tyrrhenocythere donetziensis, Bakunella dorsoarcuata, Cypria sp. (Fig. 4.8). Thereby, the taxonomic content of the microfauna assemblage is remarkably enriched within Unit H3.

In Unit H4, at 1701-1719 m, another salinity incursion is indicated by the presence of euryhaline foraminifera like Ammonia and Cibicides spp. (Fig. 4.8). Dominant ostracod taxa are Eucythere naphtatscholana, Cytherissa bogatschovi, Amnicythere nata, A. caspia, A. camelii, A. cymbula as well as numerous loxoconchids including Loxoconcha eichwaldi, L. petasa, L. endocarpus, L. lepida, L. pulchella, L. gibboides. Many ostracod species show transitional morphotypes, hinting at rapid and frequent environmental changes. This suggests shallow anomalohaline/oligohaline lake environments with interrupting lagoon/littoral levels.

A further salinity incursion $(1842 \mathrm{~m})$ is marked by an abundance of euryhaline foraminifera with Ammonia sp., as well as Cassidulina sp., and Porosononion sp. (Fig. 4.8). The ostracod assemblage here is similar to the one prevailing in the lower part of Unit $\mathrm{H} 4$ and shows a strong resemblance to the recent living fauna in the Caspian Sea.

\subsubsection{Macrofauna (molluscs)}

Unit $\mathrm{H} 2$ contains scarce, partially dissolved shells and imprints of cardiids and Dreissena rostriformis and rare finds of the gastropod Pirenella caspia (Andrusov, 1902) (Fig. 4.9j). The bivalves are often paired, or with valves in close proximity, implying in situ preservation with some burrowing activity. Bivalves found in Unit $\mathrm{H} 2$ imply a very low energy muddy saline lake floor assemblage. Four Cardiidae species were observed between $395 \mathrm{~m}$ and $428 \mathrm{~m}$, and we have difficulties in establishing their identities. Cardiidae sp. A (Fig. 4.9a) is a small (about 1.2 $\mathrm{cm}$ wide) flat, thin-shelled species with very broad and very low flat ribs separated by almost obsolete grooves. The general outline resembles the modern Adacna vitrea but further study of the hinge will be required to assess whether Cardiidae sp. A can be attributed to that genus. Cardiidae sp. B (Fig. 4.9b-d) has an intermediate-sised ( $>2 \mathrm{~cm}$ wide) shell with a sub-rounded outline. The shells' ribbing is very specific: Three very distinct ribs on the posterior half of the 


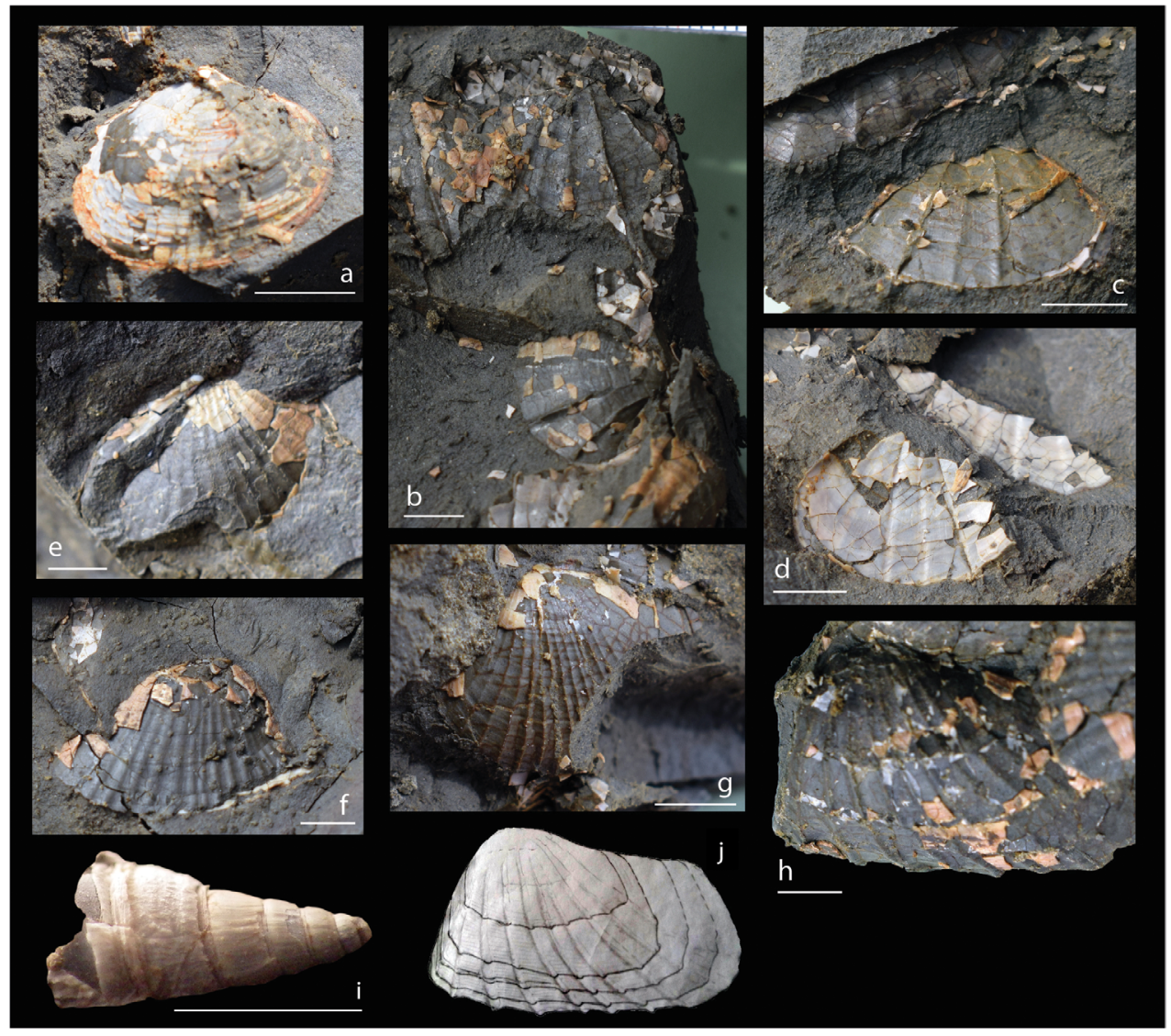

Figure 4.9 Mollusc fauna from the Akchagylian clay interval in the Hajigabul section. Scale bar $5 \mathrm{~mm}$. (a). Cardiidae sp. A. (428 m); (b-d). Cardiidae sp. B. (395 m); (e-g). Cardiidae sp. C (395 m); (h, j). Avicardium nikitini (395 m); ((i) is a reconstruction); (i) Pirenella caspia (288 m).

disk give way to three low and imbricate ribs on the anterior side. The fine ribs do resemble those of Parapsheronia raricostata s.l. from the Apsheronian, but the resemblance is superficial. No imbricated anterior ribs are known for Parapsheronia and the erect posterior ribs in Cardiidae sp. B are much thinner with wide, almost concave, interspaces. The posterior margin of the former species is smooth. Cardiidae sp. B has some commonalities with the Akchagylian species Avicardium radiiferum (see Danukalova, 1996, pl. 14, figs. 1-4). Yet, the new material appears to have a rhomboid shape and not an elongated shape as in the latter. Cardiidae sp. C (Fig. 4.9e-g) is a very thin-shelled, slightly convex, sub-rounded, sub-triangular to subrectangular species wearing approximately 20 thin erect posterior ribs at more or less equal distances with flat broad interspaces. In some specimens, the ribbing becomes more irregular towards the posterior margin. Cardiidae sp. C has a similar shape as some of the Miricardium 


\begin{tabular}{|c|c|c|c|c|c|c|c|c|c|c|c|c|c|c|c|}
\hline 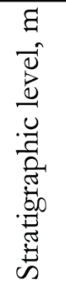 & 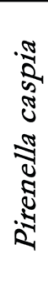 & 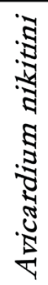 & 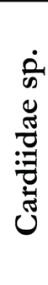 & 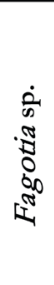 & 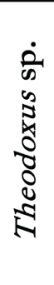 & 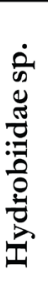 & 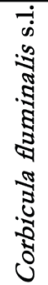 & $\begin{array}{l}\dot{\dot{s}} \\
\dot{0} \\
\dot{0} \\
\dot{s}\end{array}$ & 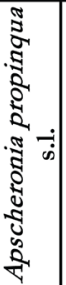 & 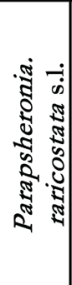 & 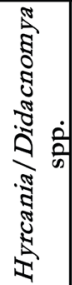 & 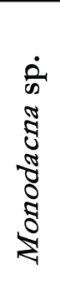 & 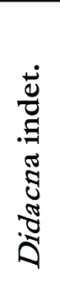 & 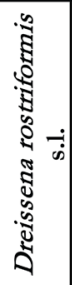 & 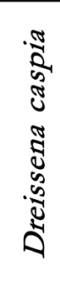 \\
\hline 1616 & & & & & & & & & & & & & & $\mathrm{X}$ & \\
\hline 1567 & & & & & & $\mathrm{X}$ & & & $?$ & & $\mathrm{X}$ & & & $\mathrm{X}$ & \\
\hline 1563 & & & & & & & & & & & & & & $\mathrm{X}$ & \\
\hline 1561 & & & & & & $x$ & & & $\mathrm{X}$ & & $x$ & $\mathrm{X}$ & $\mathbf{X}$ & $\mathrm{X}$ & \\
\hline 1560 & & & & & & & & & $X$ & & $x$ & $\mathbf{X}$ & & $X$ & $X$ \\
\hline 1444 & & & & & & & & & & & $?$ & & $?$ & $\mathrm{X}$ & \\
\hline 1442 & & & & & & & & & $\mathrm{X}$ & & & $\mathbf{X}$ & & & \\
\hline 1427 & & & & & & & $\mathrm{X}$ & $\mathrm{X}$ & & & 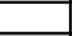 & - & & & \\
\hline 1425 & & & & & & $\bar{X}$ & & & & & & & & $\bar{X}$ & \\
\hline 1415 & & & & & & & & & $\mathrm{X}$ & & $\mathrm{X}$ & $\mathrm{X}$ & $?$ & $\mathrm{X}$ & \\
\hline 1407 & & & & & & & & & & & $\mathbf{X}$ & $\mathrm{X}$ & & $\mathrm{X}$ & \\
\hline 1398 & & & & & & & & & & & $\mathrm{X}$ & $\mathrm{X}$ & & $\mathrm{X}$ & \\
\hline 1390 & & & & & & & & $X$ & & & & 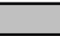 & & & \\
\hline 1383 & & & & & & & & $\mathbf{X}$ & & & & & & & \\
\hline 1380 & & & & & & & & $\mathbf{X}$ & & & & & & & \\
\hline 1335 & & & & & & & & & $\mathrm{X}$ & & $?$ & $\mathbf{X}$ & $?$ & & \\
\hline 1333 & & & & & & & & & & & $x$ & $\mathbf{X}$ & & & \\
\hline 1293 & & & & & & & & & & & $X$ & $\mathbf{X}$ & & & \\
\hline 1292 & & & & & & & & & & & & & & $\mathrm{X}$ & \\
\hline 1265 & & & & & & & & & & & & $\mathrm{X}$ & & & \\
\hline 1262 & & & & & & & & & & & & & & $\mathbf{X}$ & \\
\hline 1191 & & & & & $\mathbf{X}$ & & & & & & $?$ & $\mathrm{X}$ & $?$ & & \\
\hline 923 & & & & & & $X$ & & & & $?$ & & $\mathbf{X}$ & & $\mathbf{X}$ & \\
\hline 907 & & & & & $\mathbf{X}$ & $\mathrm{X}$ & & & $\mathrm{X}$ & & & $\mathrm{X}$ & & $\mathrm{X}$ & $\mathrm{X}$ \\
\hline 906 & & & & & & & & & $\mathrm{X}$ & & & & & & \\
\hline 749 & & & & & & & & & $\mathrm{X}$ & & 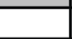 & 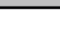 & & $\mathrm{X}$ & \\
\hline 747 & & & & & & $X$ & & & $\bar{x}$ & & & & & $\mathrm{X}$ & \\
\hline 743 & & & & $\mathrm{X}$ & $X$ & & & & & & $?$ & $?$ & & & \\
\hline 707 & & & & & $\mathbf{X}$ & $X$ & & & & & & $\mathrm{X}$ & & $\mathrm{X}$ & \\
\hline 703 & & & & & $\mathbf{X}$ & $\mathrm{X}$ & $\mathrm{X}$ & & $\mathrm{X}$ & & & $\mathrm{X}$ & & $\mathrm{X}$ & \\
\hline 683 & & & & & & & & $X$ & & & & $\mathrm{X}$ & & $\mathrm{X}$ & \\
\hline 681 & & & & & & & $\mathrm{X}$ & $\mathrm{X}$ & & & & & & $\mathrm{X}$ & \\
\hline 678 & & & & & & $x$ & & & $?$ & & & $\mathrm{X}$ & & $\mathrm{X}$ & \\
\hline 636 & & & & & & & & & $\mathrm{X}$ & & & $\mathrm{X}$ & & & \\
\hline 620 & & & & & & & & & $\mathrm{X}$ & & & $\mathbf{X}$ & & $\mathrm{X}$ & \\
\hline 616 & & & & & & & & & $\bar{X}$ & & & $\mathrm{X}$ & & $\mathrm{X}$ & \\
\hline 569 & & & & & & $\mathbf{X}$ & & & $\mathrm{X}$ & & & & & $\mathrm{X}$ & \\
\hline 568 & & & & & & $\mathrm{X}$ & & & $\mathrm{X}$ & & & $\mathrm{X}$ & & $\mathrm{X}$ & \\
\hline 564 & & & & & & & $\mathrm{X}$ & & $\mathrm{X}$ & & & $\mathbf{X}$ & & & \\
\hline 563 & & & & & $X$ & $X$ & & & $\mathrm{X}$ & & & $\mathrm{X}$ & & $\mathrm{X}$ & \\
\hline 558 & & & & & & & & & & & & $X$ & & $X$ & \\
\hline 557 & & & & & & & & & & & & $\mathrm{X}$ & & $\mathrm{X}$ & \\
\hline 532 & & & & $\mathbf{X}$ & & $\mathbf{X}$ & & & & & & & & $\mathrm{X}$ & \\
\hline 428 & & & $\mathbf{X}$ & & & & & & & & & & & & \\
\hline 395 & & & $\bar{X}$ & & & & & & & & & & & & \\
\hline 330 & & $\mathrm{X}$ & & & & & & & & & & & & & \\
\hline 315 & & $\mathbf{X}$ & & & & & & & & & & & & & \\
\hline 288 & $\mathrm{X}$ & & & & & & & & & & & & & & \\
\hline
\end{tabular}

Table 4.2 Distribution of Akchagylian and Apsheronian mollusc taxa in the Hajigabul section. 
caracutum (see Danukalova, 1996, pl. 12, figs. 1-10) but that shape-variable species has lesser ribs. Several imprints are attributed to Avicardium nikitinum (Andrusov, 1902) (Figs. 4.9h, I, see for comparison Danukalova, 1996, pl. 13, fig. 4)). The species is relatively large $(3 \mathrm{~cm})$, convex and irregular sub-quadrangular. The anterior margin appears truncated; the posterior margin is greatly expanded. Approximately ten well-developed ribs occur with wide flat interspaces about three times as wide. The shell has a Pholadomya outline. The outline also resembles the Apsheronian Adacna(?) andrusovi as illustrated in Kolesnikov (1950) (table 26, figs. 4-6). Yet, the latter species appears to have strong ribbing throughout the shell whereas ribbing in our material fades towards the posterior end. Attribution of this mollusc fauna to the Akchagylian is tentative and open to further scrutiny. The presence of Pirenella caspia and Avicardium nikitini are the best indicators (Fig. 4.9i, j). The cardiids of Cardiidae sp. A, B and C in the section likely represent a deep-water fauna that requires further taxonomic elaboration.

In Unit 3, new oligo- mesohaline communities with Dreissena rostriformis, Monodacna sp., and Apscheronia propinqua s.l. occur (Table 4.2). Besides that, freshwater intervals dominated by Unio are also present. We correlate unit $\mathrm{H} 3$ to the Apsheronian. Two other smooth Apscheronia species have been reported before (A. brevior and A. preextensa). The distinction in species is mainly based on the height/width ratios of adult specimens. In the studied material, however, mainly juvenile and broken specimens were found, and we lumped these into Apscheronia propinqua s.l. Other occurrences, such as Hyrcania, Didacnomya and Monodacna spp. confirm the Apsheronian age.

Unit H4 contains several faunal levels that yield Middle Pleistocene faunas (Table 4.3). The section itself has been documented along a small river valley parallel to the main one (Section B). Here we report on the age-diagnostic Didacna species (Fig. 4.10). Sample 18DS09 (1795 m) was an indurated claystone layer with cracked, partially dissolved Didacna, which were paired but could not be sampled. Here, we identified in the field an assemblage containing Didacna corpulenta, D. parvula, D. cf. carditoides and D. alibajramlinica. Higher in the section, at 1860 m, we found Didacna eulachia, D. charamica, D. subpyramidata and D. trigonula. In the upper

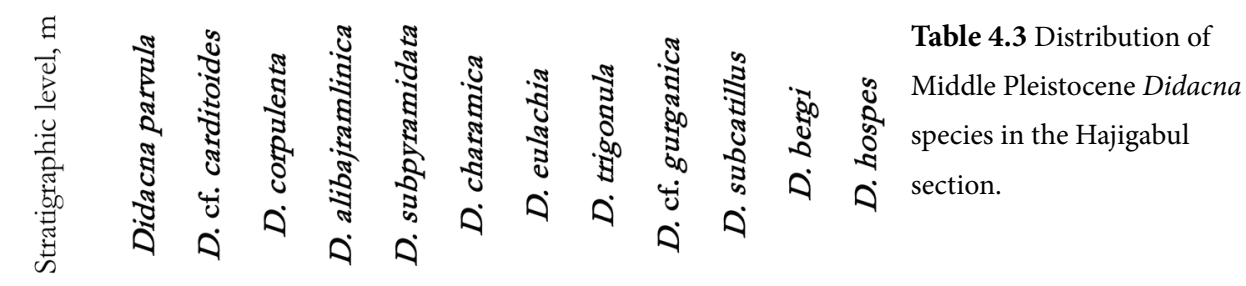

$$
\begin{array}{llllllllll}
\hline 1954 & & & & X & X & X & X & X & X \\
1860 & X & X & X & X & & & & \\
& & X & X & X & & & & & \\
\end{array}
$$

$1795 \quad X \quad X \quad X \quad X$ 


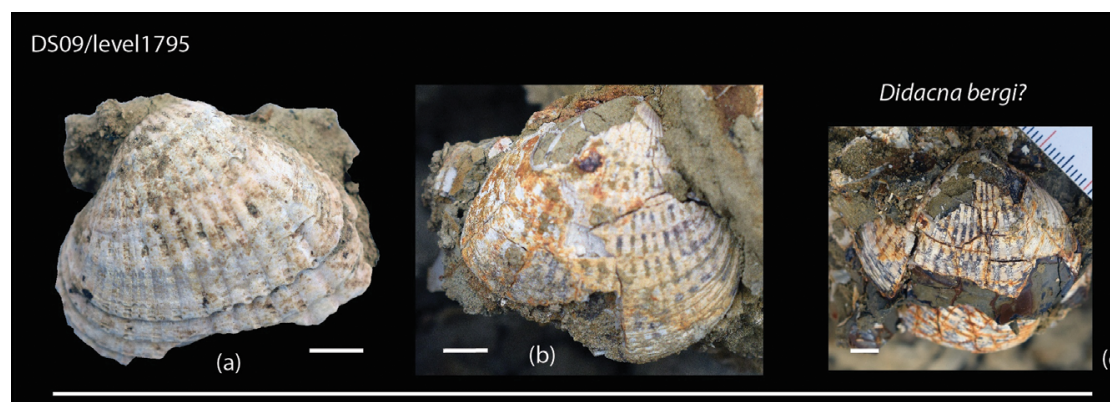

(c)

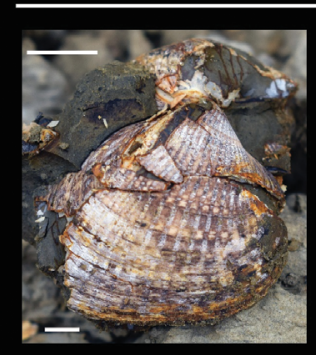

(d)
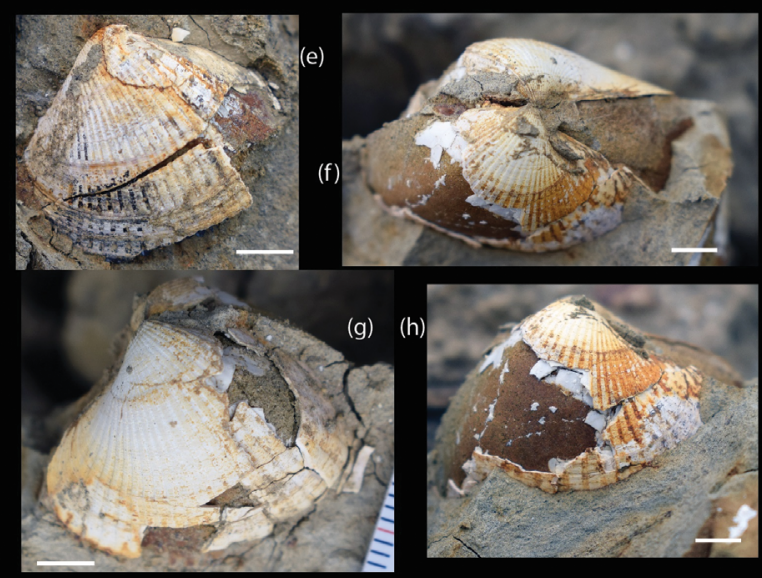

Didacna parvula?

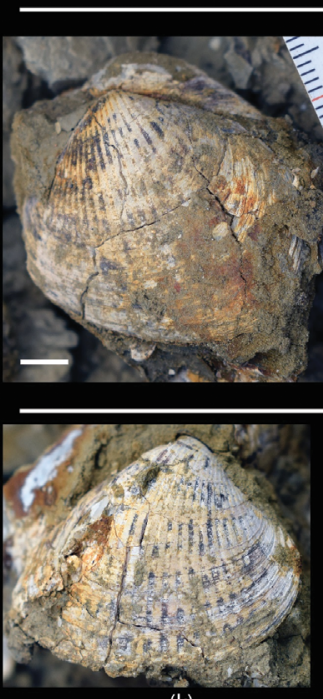

(k)

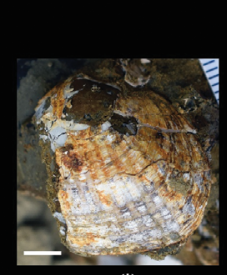

(I)

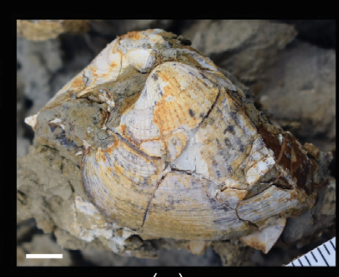

(m)
Didacna cf carditoides

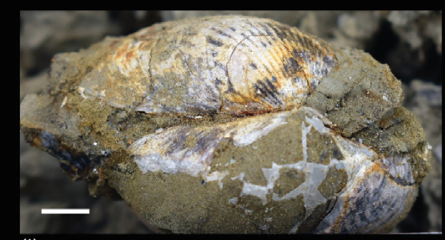

(i)

Figure 4.10. Middle Pleistocene Didacna species from the Hajigabul section. Scale bar 5 mm. A-B.

Didacna bergi (1954 m, early Khazarian); C-G. D. parvula (1795 m, Late Bakunian); H-I. D. cf. carditoides (1795 m, Late Bakunian); J-K. Didacna sp. (1795 m, Late Bakunian). 
part of Unit H4, at 1954 m sediments contain Didacna bergi, D. hospes, D. cf. gurganica, D. trigonula, D. eulachia, D. subcatillus and Corbicula cf. fluminalis.

\subsubsection{Palaeomagnetism}

Demagnetization of 181 samples from the Hajigabul section revealed two NRM components: a low-temperature (LT_N) and high (medium) temperature component that is directed towards the origin of the Zijderveld diagram (MT, HT). The low-temperature component typically demagnetizes between $180^{\circ}$ and $250^{\circ} \mathrm{C}$ (Fig. 4.11A). The mean direction of this component has values of $\mathrm{D}=359.3^{\circ}, \mathrm{I}=54^{\circ}, \mathrm{k}=27$, a95 $=2.6$ for $\mathrm{N}=116$ samples in geographic coordinates (Fig. 4.11B). The present-day magnetic field parameters for the Hajigabul section are $\mathrm{D}=6.07^{\circ}, \mathrm{I}=59.26^{\circ}$ (https://www.ngdc.noaa.gov, April 2017). We interpret the low-temperature component as present-day field overprint. The second component consists of two sub-groups: medium temperature (MT_R, MT_N) and high temperature (HT_N, HT_R) components. The medium temperature component fully demagnetizes at $400^{\circ} \mathrm{C}$ and represents an iron sulphide, most likely greigite. The high-temperature component is fully demagnetised at $580^{\circ} \mathrm{C}$ (Fig. 4.11C). Thermomagnetic runs show convex curves that gradually decrease down to $580^{\circ} \mathrm{C}$ (Fig. 4.11D). We define this carrier as magnetite.

All samples with MT and HT components are combined in two groups: all normal and all reversed (Fig. 4.11E, F). The mean direction for all normal samples in tectonic coordinates (tc) has parameters of $\mathrm{D}=339.1^{\circ}, \mathrm{I}=49.6^{\circ}, \mathrm{k}=14.2$, a95 $=5.9$ for $\mathrm{N}=45$ (Fig. 4.11E), while for all reversed samples $\mathrm{D}=204.2^{\circ}, \mathrm{I}=-36.7^{\circ}, \mathrm{k}=12.7$, a95 $=5.7$ for $\mathrm{N}=54$ (Fig. 4.11F). The mean directions of the ChRM are assumed to be distributed along the dipole axis (Piper and Grant, 1989). Nevertheless, the reversal test is negative. The ChRM directions deviate from the dipole axis towards the West, where the current day overprint (LT_N) is located (Fig. 4.11G). Thermal demagnetization revealed two different types of demagnetization with either two distinctive magnetic components (Sample DSD2, Fig. 4.11H) or with one component smoothly passing into a second component (samples DS5 and DS 162, Fig. 4.11I). The latter probably results from an overlap between two coercivity fractions of two magnetic components (Tauxe, 2010). This,

Figure 4.11 (next page) Equal area plots, Zijderveld diagrams and thermomagnetic curves for samples of the Hajigabul section. Equal are plots for: B coordinates (tc); E. All normal ChRM directions - in situ and in tectonic coordinates (tc); F. All reversed ChRM directions - in situ and in tectonic coordinates (tc); G. All mean directions for all reversed (MT_R and HT_R), all normal (HT_N and MT_N) and LT_N groups; L. Remagnetised samples marked as "Full overprint" (FO) - in situ and in tectonic coordinates (tc); A, C, H- Characteristic Zijderveld diagrams for various samples. D, M - thermomagnetic runs for various samples; Zijderveld diagrams with separate $(\mathrm{H})$ and overlapped (I) demagnetization of two components. $J$ - Zijderveld diagram given for one sample measured with different techniques: th - thermally demagnetised, af - demagnetised in alternating field. 


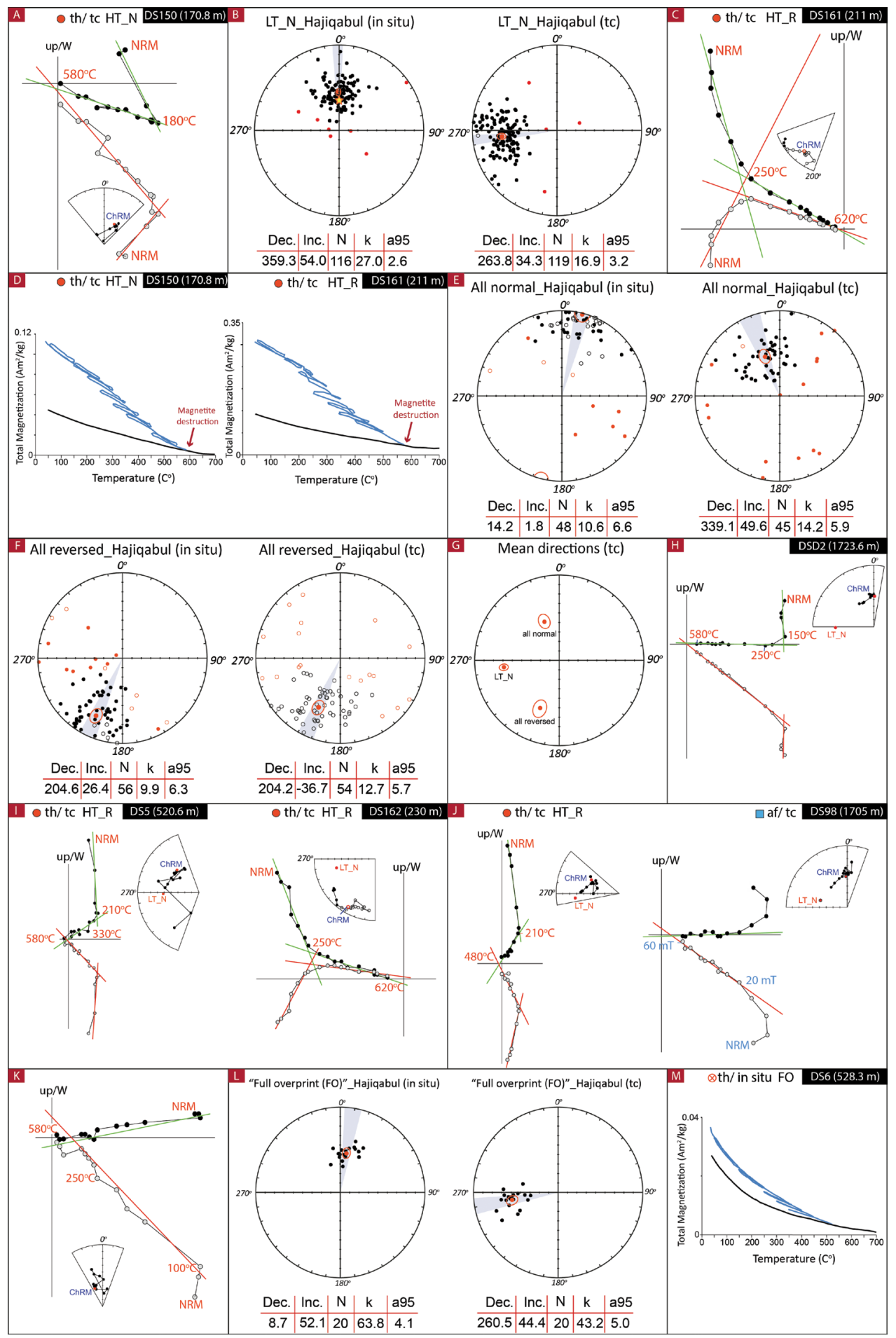


in turn, declines the ChRM direction towards the West. To verify the second component as original, we measured some doublet samples in alternating field (Fig. 4.11J).

A separate group of 20 samples contains only one magnetic component. These samples are demagnetised in a wide range of temperatures, between $300^{\circ} \mathrm{C}$ and $580^{\circ} \mathrm{C}$ (Fig. $4.11 \mathrm{~K}$ ). The mean direction for this group has $\mathrm{D}=8.7^{\circ}, \mathrm{I}=52.1^{\circ}$ in situ (Fig. $4.11 \mathrm{~L}$ ). It is very close to the present-day local magnetic parameters, and we conclude that these samples show "full overprints". For this group of samples, the thermoremanent curves have concave shapes and gradually decrease down to $530-550^{\circ} \mathrm{C}$. After cooling, the magnetisation of the samples turned back almost to the same level as before the measurement (Fig. 4.11M). Such behaviour suggests that "full overprint" samples have a paramagnetic carrier with low coercivity.

The polarity pattern of the Hajigabul section comprises four normal, and three reversed polarity zones (Fig. 4.12). Palaeomagnetic investigations started in the sedimentary Unit H1 at $170.8 \mathrm{~m}$, below the last sandstone of that unit. Here we registered a normal polarity zone (N1) that switches to reversed (R1) at $179.5 \mathrm{~m}$. This reversed zone (R1) continues up to $509.7 \mathrm{~m}$, where a reversal to normal polarity (N2) occurs. A short normal zone (N2) is revealed between 509.7 and $568.2 \mathrm{~m}$. It is followed by a reversed zone (R2) in the interval $568.2-802.5 \mathrm{~m}$, which is

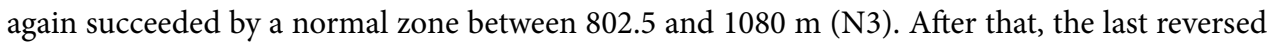
zone (R3) extends from $1080 \mathrm{~m}$ to $1641.5 \mathrm{~m}$ and covers the second half of the sedimentary Unit H3. The last normal zone (N4) starts at $1641.5 \mathrm{~m}$ and continues until the end of the section, up to $2050 \mathrm{~m}$. It covers the boundary between the third and fourth sedimentary units. In this zone, we found an interval between $1738 \mathrm{~m}$ and $1775 \mathrm{~m}$ with a set of uncertain magnetic directions. They usually have two magnetic components, but the ChRM directions have incompatible values of declination and inclination. However, most of the measurements made in alternating field suggest a normal polarity (Fig. 4.12).

\subsection{Discussion}

\subsubsection{Correlation to the Global Polarity Time Scale (GPTS)}

\subsubsection{Goychay section}

The polarity pattern of the Goychay section consists of a dominantly reversed polarity interval with three small normal zones (N1-3) of which the middle one (N2) is the longest, separated by four reversed zones (R1, R2, R3 and N4) (Fig. 4.7). Given the available biostratigraphic age constraints for Units G1 and G2 (Akchagylian/Apsheronian), the reversed polarities are likely to correspond to the Matuyama chron (2.59-0.78 Ma). The most straightforward correlation of the Goychay magnetostratigraphy is then to the middle part of the Matuyama chron where: R1 is correlated to C2r.2r, N1 to C2r.1n (Reunion), R2 to C2r.1r, N2 to C2n (Olduvai), R3 to C1r.3r, N3 to C1r.2n (Cobb Mountain) and R4 to C1r.2r (Fig. 4.13). 


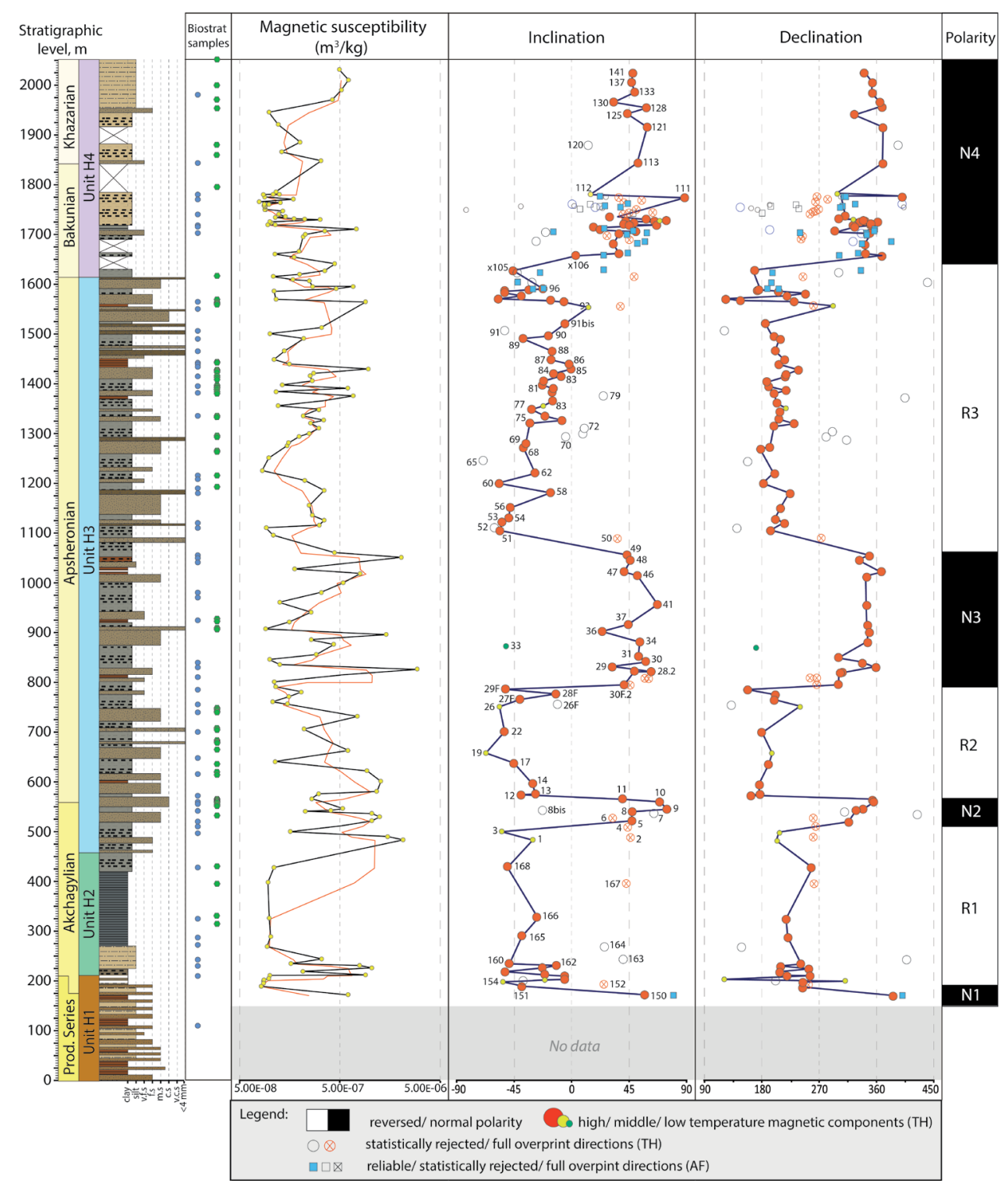

Figure 4.12 Magnetostratigraphy of the Hajigabul section. In columns from left to right: Regional stages;

Depositional units; Lithological log; Biostratigraphic sampling points, where green points are mollusc samples and blue points - microfauna samples; Magnetic susceptibility (plotted on a logarithmic scale); Inclination; Declination; Interpreted polarity. 


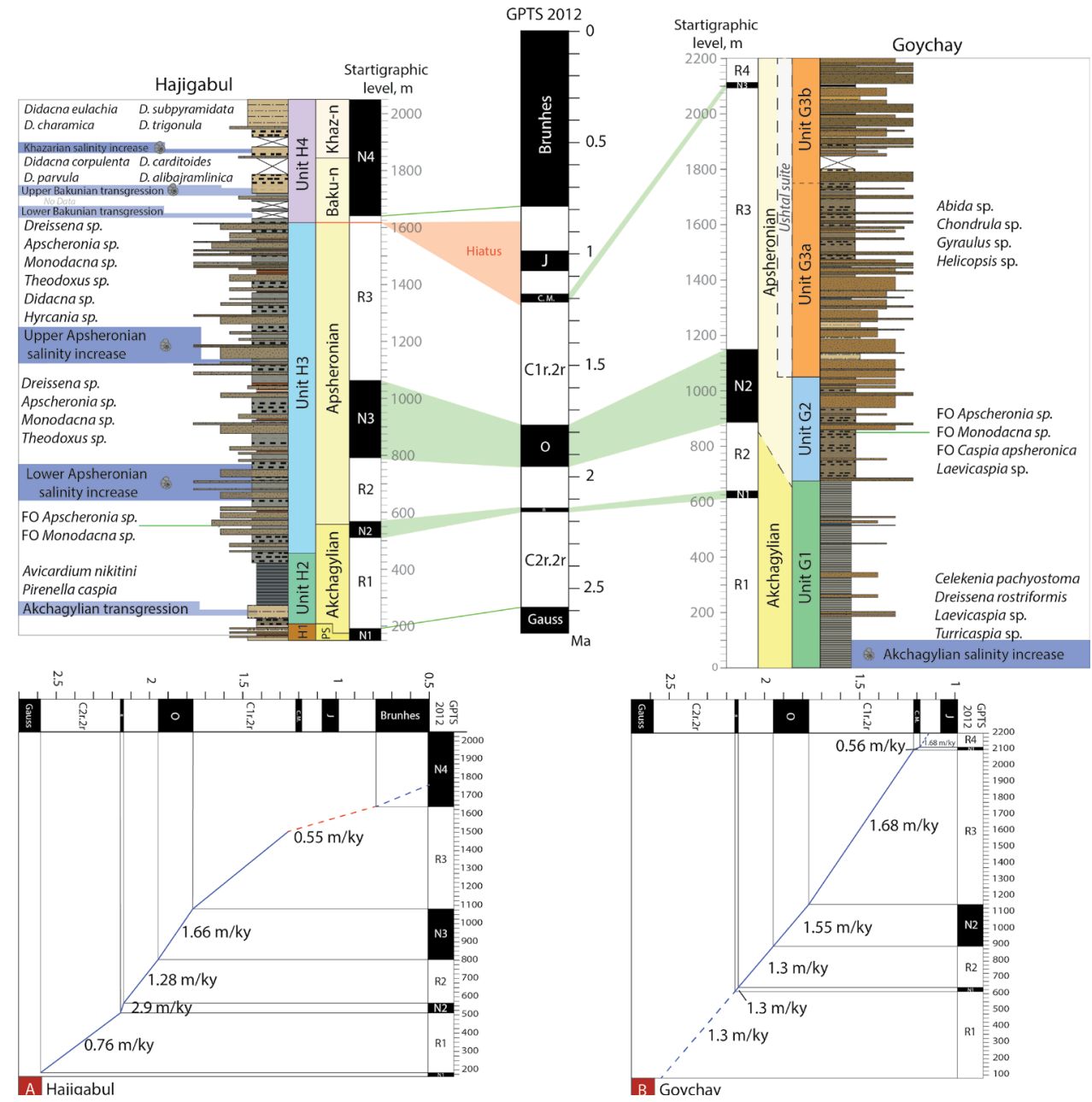

Figure 4.13 Correlation of polarity patterns to the Global Polarity Time Scale (GPTS), the main

palaeoenvironmental events and characteristic mollusc fauna in the Goychay and Hajigabul sections.

Sedimentation rate curves: Hajigabul section (A), the Goychay section (B).

This magnetostratigraphic correlation allows us to assess the average sediment accumulation rates in the section. It shows a gradual upward increase from $1.3 \mathrm{~m} / \mathrm{kyr}$ to 1.68 $\mathrm{m} / \mathrm{kyr}$, in good agreement with the observed coarsening-upward trend in the section (Fig. 4.13). Extrapolating the sedimentation rate of $1.3 \mathrm{~m} / \mathrm{kyr}$ to the lowermost part, we calculate that the base of the Goychay section has an age of $2.55 \mathrm{Ma}$. It confirms that the upper part of the Gauss chron $(2.58 \mathrm{Ma})$ is not reached here. The major palaeoenvironmental change from mesohaline to oligohaline conditions at $110 \mathrm{~m}$ (Fig. 4.3) is then dated at $2.5 \mathrm{Ma}$. The significant change in depositional environments (From Unit G1 to Unit G2) and the remarkable FCO of 
Tyrrenocythere azerbaijanica occur slightly above the Reunion subchron and have an age of 2.1 Ma. Extrapolation of the sediment accumulation rate of $1.68 \mathrm{~m} / \mathrm{kyr}$ for the upper part of the section gives an age of $1.13 \mathrm{Ma}$ for the top of the section, confirming that the small normal zone $\mathrm{N} 3$ best correlates to the Cobb Mountain subchron (1.215 Ma - 1.178 Ma).

\subsubsection{Hajigabul section}

The polarity pattern of the Hajigabul section shows four normal polarity intervals (N1, N2, N3 and N4) and three reversed polarity intervals (R1, R2 and R3) (Fig. 4.13). This pattern does not allow for a straightforward correlation to the GPTS and suggests that several subchrons of the GPTS are missing in this record. Our biostratigraphic data constrain the reversed polarity intervals to the Akchagylian-Apsheronian, i.e., to the Gauss and/or Matuyama chrons (maximum ages between 3.6 and $0.78 \mathrm{Ma}$ ). We consider a correlation of N1-3 to the polarity pattern of the Gauss chron highly unlikely because the two lower reversed intervals are significantly longer than the normal interval N2. Hence, we correlate the lowermost reversed interval to the lower part of the Matuyama chron, conforming to the correlation of the Goychay section. Besides, several other studies have recently determined the Productive SeriesAkchagylian transition to occur in the uppermost part of the Gauss chron at the age of $2.7 \mathrm{Ma}$ (Richards et al., 2018b; Hoyle et al., 2019b; van Baak et al., 2019). Following these results, N1 correlates to chron C2An.1n (upper Gauss), R1 to C2r.2r, N2 to C2r.1n (Reunion), R2 to C2r.1r, $\mathrm{N} 3$ to C2n (Olduvai) and R3 to C1r.3r (Fig. 4.13). This magnetostratigraphic correlation dates the Akchagylian-Apsheronian transition in the Hajigabul section within the Reunion subchron at the age of $\sim 2.13 \mathrm{Ma}$.

The long normal zone N4 comprising the Bakunian and Khazarian most likely correlates to C1n (Brunhes) (Krijgsman et al., 2019 and references therein). This implies that the small normal subchrons C1r.2n (Cobb Mountain) and C1r.1n (Jaramillo) are missing in the Hajigabul section. We did not observe clear evidence for a hiatus in the section but think that the most plausible conclusion is that the upper part of the Apsheronian has been removed by erosion prior to the Bakunian transgression (Fig. 4.13). An alternative option, correlating from the Brunhes chron downwards, is the magnetostratigraphically feasible correlation of N3-N2 to Jaramillo-Cobb Mountain. However, this would infer an erroneously young age for the uppermost Akchagylian, and can thus be rejected. The presence of lower Khazarian deposits in the upper part of the Hajigabul section indicates an age of $\sim 0.374 \mathrm{Ma}$ (Saltykov, 2011; Krijgsman et al., 2019).

According to our preferred magnetostratigraphic correlation, the sediment accumulation rates are relatively low in the Akchagylian part of the Hajigabul section (Unit H2: $0.76 \mathrm{~m} /$ kyr). The sediment accumulation curve increases upwards $(1.28-1.66 \mathrm{~m} / \mathrm{kyr})$ at the Reunion subchron at $\sim 2.1 \mathrm{Ma}$. This abrupt increase closely coincides with the main palaeoenvironmental change from the dark Akchagylian claystones of Unit $\mathrm{H} 2$ to the Apsheronian sandstones of 
Unit H3 (Fig. 4.13). Sediment accumulation rates for Unit 3 are not complete due to the hiatus in the uppermost part. This complicates precise dating of the Lower Bakunian transgression (Apsheronian-Bakunian boundary) at $1616 \mathrm{~m}$. A rough calculation of sedimentation rates for the R3 zone results in $0.55 \mathrm{~m} / \mathrm{kyr}$ and the age of the Bakunian transgression at $0.85 \mathrm{Ma}$. Sedimentation rates calculated for Unit 4, using two theoretical time points - the base of Khazarian Stage at 0.374 Ma (Saltykov, 2011; Krijgsman et al., 2019) and the MatuyamaBrunhes reversal at $0.781 \mathrm{Ma}$, provide a $0.42 \mathrm{~m} / \mathrm{kyr}$ rate and 0.83 age of the Bakunian transgression. Thereby, we estimate the age of the lower Bakunian transgression between 0.85$0.83 \mathrm{Ma}$.

\subsubsection{Palaeoenvironmental evolution}

Here we combine our data on depositional environments, mollusc fauna, microfauna and magnetostratigraphy in chronological order with the aim to provide a reconstruction of palaeoenvironments in the Kura Basin in the South Caspian region. The ages of the key-events are acquired through extrapolation of average sedimentation rates that are derived from our magnetostratigraphic correlations (Fig. 4.13).

\subsubsection{The Productive Series-Akchagylian transition (Hajigabul section, 2.7-2.6 Ma)}

The Productive Series-Akchagylian transition is marked by a major transgressive event. Fluvial sandstones with freshwater faunas of the Productive Series (H1) are overlain by distal open-water claystones with oligohaline faunas of the Akchagylian (H2). This transition is present only in the Hajigabul section, where it is roughly dated at the top of the Gauss chron at an estimated age of $\sim 2.6 \mathrm{Ma}$. In the Goychay section, the transition is not exposed because a major thrust fault cuts through the sedimentary succession above this level (Fig. 4.1c), (Forte et al., 2013).

Depositional environments and corresponding freshwater microfauna described in the Productive Series (Unit H1) of the Hajigabul section are similar to other sections in the Kura Basin (Lokbatan, Jeirankechmez, Babazanan) (Vincent et al., 2010; van Baak et al., 2013). Transition, from continental to deep-water offshore environments between $175 \mathrm{~m}$ and $205 \mathrm{~m}$, is interpreted as the Akchagylian transgression. This transitional Productive Series-Akchagylian interval in our section, unfortunately, lacks micropalaeontological data. The biostratigraphic samples from $210 \mathrm{~m}$ onwards reveal rich oligohaline ostracod assemblages, representative for the Akchagylian stage. In the other sections across the Kura Basin, the Akchagylian transgression is characterised by marine benthic foraminifera, including species of Cassidulina and Cibicides, and marine dinocysts (Algidasphaeridium cf. capillatum) indicating a potential influx of Arctic waters (Richards et al., 2018b; Hoyle et al., 2019b). The transitional interval in Hajigabul is, however, marked by the presence of several volcanic ash layers. We assume that these are similar to those present within the transitional interval in the Jeirankechmez and 
Lokbatan sections, that were recently radio-isotopically (40Ar/39Ar) dated at 2.7-2.6 Ma (van Baak, 2015a; Hoyle et al., 2019b; van Baak et al., 2019). Our results are thus in good agreement with the other sections in the Kura Basin.

\subsubsection{The Akchagylian (Hajigabul and Goychay, 2.6-2.1 Ma)}

The major part of the Akchagylian deposits in both the Goychay and Hajigabul sections consists of grey mudstones, representing offshore depositional environments with mostly anomalohaline faunas. The Hajigabul section has an impoverished Akchagylian fauna. Indicative Akchagylian species such as Cerastoderma dombra and Avimactra subcaspia are lacking: the habitat of these species likely was very shallow while depositional depths in the Hajigabul were deeper (Paramonova, 1994; Danukalova, 1996). In the Hajigabul section, deep water facies contain rare, poorly-preserved cardiids, the Akchagylian-indicative gastropod Pirenella caspia and bivalve Avicardium nikitini (Fig. 4.9), and anomalohaline ostracod associations (Fig. 4.8). Despite a presence of rare molluscs, no foraminifers have been detected in the lowermost Akchagylian part of the section, which might be linked with bad preservation potential of foraminifers in this particular interval or with low micropalaeontological sampling resolution.

Indicative Akchagylian bivalve species have not been found in the Goychay section. The lowermost part contains brackish water ostracods and abundant foraminifera indicating mesohaline conditions. Above $99.4 \mathrm{~m}$, foraminifera disappear, and brackish ostracods decline both in abundance and species numbers, indicating a decrease of salinity. The transition from mesohaline to oligohaline conditions in Goychay is dated at 2.5 Ma. A similar switch to lower salinity faunas has been described in the Jeirankechmez section, where it was interpreted to correlate to the termination of marine Arctic waters entering the Caspian Basin (van Baak et al., 2019). Starting from 2.4 Ma, the Goychay section displays first prodeltaic facies that are associated with freshwater/oligohaline mollusc groups with Theodoxus, Corbicula and hydrobiids (Fig. 4.3, Table 4.1). Presence of lower salinity fauna in prodeltaic facies suggests freshening of the basin margins due to local river freshwater input. Such early deltaic progradation in this area likely happened due to progradation of the Kura thrust-fold belt that turned the Goychay area into a semi-isolated piggy-back basin (Forte et al., 2013). The absence of Akchagylian indicator bivalve species in the Goychay section can be explained by the presence of an unsuitable habitat: fast transition from deep-water environments $(0-120 \mathrm{~m})$ to freshened conditions of prodelta with low oligohaline/freshwater fauna (120-675 m). Another exciting aspect of the Goychay faunal record is the presence of Caspia species gastropods (Caspia matura and C. apsheronica). These gastropod species have so far only been reported from Apsheronian deposits, yet they may have been present already in marginal Akchagylian environments. 
Similar complications in the upper Akchagylian are known from the sections in West Turkmenia, where freshening of marginal parts of the basin caused the depletion of Akchagylian indicator molluscs (Markova, 1962). There, non-indicative hydrobiid and dreisseniid species prevail over a low number of Akchagylian molluscs species and thus leave open the question of a clear Akchagylian-Apsheronian boundary in that region (Markova, 1962).

In the west Kura Basin (Kvabebi) and West Turkmenia (Pyrnaur), the indicative Akchagylian molluscs of genera Avicardium, Avimactra, Pirenella etc. are the most abundant in shallow water facies (limestones, sandstones) (Danukalova, 1996; Agustí et al., 2009). In Hajigabul, the scare molluscs were found in the clayey Unit $\mathrm{H} 2$ that was interpreted to be deposited in distal open-water environments. Thereby, we assume that the Akchagylian depositional environments in Hajigabul could be unfavourable (too deep) for the indicative Akchagylian molluscs, that explains their limited distribution and poor preservation.

\subsubsection{The Akchagylian-Apsheronian transition (Hajigabul and Goychay, $2.1 \pm 0.1 \mathrm{Ma}$ )}

The Akchagylian-Apsheronian transitional interval is characterised by a lithological regressive trend and occurrence of new mollusc groups. Both the Hajigabul and Goychay sections show a sudden increase in coarser clastic material (sandstones or conglomerates; Unit H3 and G2). The first sandstones in Hajigabul occur at $457 \mathrm{~m}$ marking the onset of the regressive trend (boundary H2-H3, Fig. 4.8). Above in the section, sandstones become coarser and pass into the short interval with terrestrial facies represented by medium-grained sandstones and palaeosoils at $616 \mathrm{~m}$ (Fig. 4.8) (Jorissen et al., 2019). In Goychay, the beginning of the regressive trend is not clear due to turbidite layers within unit G1 (Fig. 4.3). However, the first shallow-water facies expressed as a thick conglomerate bed occur at $675 \mathrm{~m}$ (boundary G1G2, Fig. 4.3). The level $675 \mathrm{~m}$ in Goychay and $616 \mathrm{~m}$ in Hajigabul are chronostratigraphically synchronous and dated at 2.1 Ma. The appearance of these facies in Goychay was previously linked to the initiation of the Akharbakhar thrust system (Forte et al., 2013). However, as these shallow facies coincide in palaeogeographically remote sections, we assume that they might be related to a more substantial, basin-scale palaeoenvironmental change. In the Caspian Basin, the upper Akchagylian was described as a regressive interval that occurred around the Reunion subchron (2.12-2.14 Ma) (Zubakov, 1974; Yakhimovich and Suleymanova, 1981; Zubakov and Borzenkova, 1990). Thereby, we assume that the shallowing/prograding trend in both sections at 2.1 Ma is linked to regression of the Caspian Basin that occurred in the end of Akchagylian. The Akchagylian-Apsheronian transitional interval in Hajigabul (557-616 m) comprises a change in fauna, showing the first occurrences of indicative Apsheronian mollusc species Monodacna sp. $(557 \mathrm{~m})$ and Apscheronia propinqua $(563 \mathrm{~m})$, the ostracod species Tyrrhenocythere azerbaijanica $(616 \mathrm{~m})$ and presence of benthic foraminifera $(616 \mathrm{~m})$. This transitional interval is magnetostratigraphically dated between $2.13-2.10 \mathrm{Ma}$ (Fig. 4.8, 4.13). We, therefore, propose to place the Akchagylian-Apsheronian boundary at $557 \mathrm{~m}$ (FO of Monodacna sp.), which is dated 
at $2.13 \mathrm{Ma}$ - in the middle of the Reunion subchron (Fig. 4.13). In Goychay, the bio-events are more spread throughout the section that makes the determination of the AkchagylianApsheronian boundary there less confident. The FCO of Tyrrhenocythere azerbaijanica in Goychay is also observed at $\sim 2.1 \mathrm{Ma}(651 \mathrm{~m})$. In comparison, the first indicative Apsheronian mollusc - Apscheronia propinqua occurs at $849 \mathrm{~m}$ that is dated at 2.0 Ma (Table 4.1., Fig. 4.13). Therefore, we cannot clearly state the Akchagylian-Apsheronian boundary in the Goychay section and thus, we place it between 2.1 Ma (FCO of Terrhynocythere) and 2.0 Ma (FO of Apscheronia propinqua) (Fig. 4.13).

The newly occurred Apsheronian molluscs dominated by Monodacna and Apscheronia bivalve occur in shallow water facies - similar habitat as for the Akchagylian molluscs around the Caspian Basin (Paramonova, 1994; Danukalova, 1996; Agustí et al., 2009). The absence of the latter ones suggests their extinction prior to the occurrence of the first indicative Apsheronian bivalves and thus marks the major mollusc fauna turnover.

Despite a lack of major microfauna changes at the Akchagylian-Apsheronian boundary across the Kura Basin (Krijgsman et al., 2019), we noticed one remarkable synchronous bioevent in our sections - the FCO of Tyrrhenocythere genus (Fig. 4.3, 4.8). This bio event can potentially be used for clarification of the Akchagylian-Apsheronian boundary in other regional sections like the Jeirankechmez and Lokbatan sections, where polarity patterns and mollusc fauna are not as bright (Richards et al., 2018b; van Baak et al., 2019). In Jeirankechmez, the boundary was placed at $2.4 \mathrm{Ma}(835.98 \mathrm{~m})$ by abundant occurrence of several Amnicythere species (Richards et al., 2018b). In Lokbatan, the Akchagylian-Apsheronian boundary was established at 2.0 Ma by the FO of Tyrrhenocythere azerbaijanica (van Baak et al., 2013). In both sections, polarity patterns at the Akchagylian-Apsheronian transition are not representative, but the FCO of Tyrrhenocythere genus can be well traced.

The Akchagylian-Apsheronian boundary was commonly placed at the first normal chron after the Gauss-Matuyama boundary, previously interpreted as Olduvai (Trubikhin, 1977; Kochegura and Zubakov, 1978; Semenenko and Pevzner, 1979; Sidnev, 1985). The first occurrence of species such as Monodacna sp. and Apscheronia propinqua in the middle part of the Reunion subchron indicates the onset of the Apsheronian there. This contradiction is probably linked to the absence of the Reunion subchron in old GPTSs, hampering correct magnetostratigraphic correlations in the past. Here, we confirm that the AkchagylianApsheronian boundary in the Kura Basin corresponds to the first normal subchron of the Matuyama, but that this correlates to the Reunion subchron instead of the Olduvai subchron and has an age $\sim 2.1 \mathrm{Ma}$.

\subsubsection{The Apsheronian (Hajigabul and Goychay, 2.1-0.85 Ma)}

During the Apsheronian, depositional environments in the Goychay section were firmly controlled by the prograding Kura thrust-fold belt (Forte et al., 2015). It resulted in a transition 
to continental environments of the Unit G3 and disappearance of basinal mollusc fauna. The last Apsheronian mollusc was found at $1017.8 \mathrm{~m}$ (middle of the Olduvai chron; 1.9 Ma). At $1050 \mathrm{~m}$ the lacustrine deposits are entirely replaced by continental floodplain deposits that contain terrestrial mollusc species, such as Abida sp., Chondrula sp., Gyraulus sp. and Helicopsis sp. (1620 m) (Forte et al., 2013). The $1050 \mathrm{~m}$ point is considered the base of the local continental Ushtal Suite, dated in Goychay at $\sim 1.85 \mathrm{Ma}$.

In Hajigabul, the Akchagylian-Apsheronian transition was followed by a $100 \mathrm{kyr}$ long interval (616-755m) with elevated, mesohaline salinity conditions between the Reunion and Olduvai subchrons (2.1-2.0 Ma) (Fig. 4.13). This interval contains a rich Apsheronian mollusc assemblage with Apscheronia propinqua, Monodacna sp. and Dreissena rostriformis (Table 4.2), ostracod species Tyrrhenocythere, Euxinocythere praebosqueti, Loxoconcha babazananica and Limnocythere alveolata and abundant foraminifera Ammonia, Cibicides and Cassidulina (Fig. 4.8).

After 2.0 Ma, the Apsheronian faunas in the Hajigabul section show fluctuations between oligohaline and freshwater fauna assemblages (Fig. 4.8). This mirrors the sedimentary facies that display numerous repetitive shallowing trends, from distal offshore settings to coastal and continental environments (Jorissen et al., 2019). Within both offshore and littoral environments, oligohaline assemblages are common. Among them are the ostracod species of Loxoconcha, Amnicythere, Limnocythere (Fig. 4.8). Shallow lacustrine, coastal, continental and lagoon settings mainly contain freshwater assemblages, including Ilyocypris bradyi, Darwinula stevensoni, Candona sp. It proves that the marginal areas of the anomalohaline lake have been periodically influenced by freshwater input and points towards a close link between depositional environments and the spatial distribution of the fauna.

In the Hajigabul section, a short flooding interval with abundant foraminifera is present at $1110 \mathrm{~m}$ ( $\sim 1.7 \mathrm{Ma}$; Fig. 4.13), slightly younger than the top of the Olduvai. The close correspondence with the first occurrence of Didacna sp. at $1190 \mathrm{~m}$ suggests a (re-)connection to the Black Sea, possibly marking the lower-upper Apsheronian boundary (Nevesskaya and Trubikhin, 1984).

Another remarkable taxonomic microfauna enrichment was discovered between 1465-1490 $\mathrm{m}$, where seven new ostracod species occurred: Loxoconcha rugosa, L. lepida, L. endocarpus ?, Candona schweyeri, Tyrrhenocythere donetziensis, Bakunella dorsoarcuata, Cypria sp. (Fig. $4.8,4.13)$. Among these species, the Bakunella dorsoarcuata is known from the Kuyalnikian deposits - time equivalent of the Productive Series-Akchagylian in the Black Sea (Krijgsman et al., 2019). The other species are widely distributed in Bakunian and Khazarian deposits of the Caspian Sea, when periodical interbasinal Caspian - Black Sea connections were frequent via the Manych Strait (Svitoch et al., 2010). The massive occurrence of these forms in Apsheronian may suggest that already at that time the Caspian Sea experienced periods of reconnection and faunal exchange with the Black Sea. 


\subsubsection{The Apsheronian-Bakunian transition (Hajigabul; $\sim 0.85-0.83 \mathrm{Ma}$ )}

The Apsheronian-Bakunian boundary is marked by a transgression expressed in the section as an abrupt replacement of sandstones of Unit H3 by grey clays of Unit H4 (Fig. 4.8, $1614 \mathrm{~m}$ ). Due to low micropalaeontological sampling resolution in this part of the section, we have no biostratigraphic characteristic for the lower Bakunian transgression and thus, the ApsheronianBakunian boundary is defined here lithologically.

The roughly estimated age of the Apsheronian-Bakunian boundary (explained in paragraph 5.1.2) between $0.83-0.85 \mathrm{Ma}$ is in a good agreement with magnetostratigraphic study of the Xocashen section (Azerbaijan) that provided an age of $0.85 \mathrm{Ma}$ for the Bakunian transgression (van Baak et al., 2013). It is, however, in contrast to other studies that correlated the base of the Bakunian to the Matuyama-Brunhes polarity reversal at $0.78 \mathrm{Ma}$ (Trubikhin, 1977; Kochegura and Zubakov, 1978; Semenenko and Pevzner, 1979; Yakhimovich et al., 2000; Zastrozhnov et al., 2013)

\subsubsection{The Bakunian and Khazarian (Hajigabul, $\sim 0.85-0.3 \mathrm{Ma}$ )}

After the Lower Bakunian transgression, another, smaller-scale transgressive event was observed at $1714 \mathrm{~m}$. The abundant presence of foraminifera like Ammonia sp., Cassidulina sp. and Porosononion sp. indicate an elevated, mesohaline salinity level (Fig. 4.8). The molluscs Didacna corpulenta, D. parvula, D. cf. carditoides and D. alibajramlinica observed at $1795 \mathrm{~m}$ (Fig. 4.10, 4.13) are indicative for the upper Bakunian (Nevesskaja, 2007; Yanina, 2012; Yanina, 2013). Thereby, the Bakunian Stage in the Hajigabul section displays two lithologically defined transgression events with characteristic Upper Bakunian mollusc fauna occurring in the section above the second transgression. Division of the Bakunian stage into two substages is based on different associations of Didacna molluscs, highlighting two transgression events (Shantser, 1982; Yanina, 2013).

The upper Bakunian interval 1719-1842 $\mathrm{m}$ is characterised by a regressive trend showing a lithological change from offshore clays to nearshore silts. At $1842 \mathrm{~m}$, we discovered an influx of foraminifera such as Ammonia sp, Cibicides sp., Cassidulina sp. and Porosononion sp. (Fig. 4.8). Above, at $1860 \mathrm{~m}$, we observed lower Khazarian fauna with indicative Didacna eulachia, $D$. subpyramidata, D. charamica, D. trigonula. The species $D$. eulachia has been used in the past as an indicator for the so-called Urundzhikian substage, but has later been recorded in Khazarian deposits as well (Yanina, 2013). The following assemblage, discovered at $1954 \mathrm{~m}$ with Didacna bergi, D. hospes, D. cf. gurganica, D. trigonula, D. eulachia, D. subcatillus and Corbicula cf. fluminalis has an early Khazarian Age (Nevesskaja, 2007).

Thereby, we assume, that increase of salinity at $1842 \mathrm{~m}$, followed by occurrence of Khazarian mollusc assemblages, represents the onset of the Khazarian Stage. The upper Bakunian and Khazarian deposits are situated within the Brunhes chron and could not be dated with the magnetostratigraphic approach. The recent data indicate the beginning of the Khazarian Stage 
close to MIS 10 and dated around 0.37-0.38 Ma (Saltykov, 2011; Krijgsman et al., 2019 and references therein).

\subsection{Conclusion}

Integration of magneto- and biostratigraphy in two well-exposed sections in the Kura Basin allowed creating a robust stratigraphic framework for the Early-Middle Pleistocene history of the Caspian region. The age estimates of the regional stages have been revised: Productive Series-Akchagylian boundary situates around the Gauss-Matuyama reversal and is dated at 2.6 $\pm 0.1 \mathrm{Ma}$; Akchagylian-Apsheronian Boundary is correlated to the middle of the Reunion subchron at $2.13 \mathrm{Ma}$; Apsheronian-Bakunian boundary occurs slightly below the BrunhesMatuyama reversal at $0.85-0.83 \mathrm{Ma}$.

We discovered several major intervals with elevated (mesohaline) salinity: 2.6-2.5 Ma (base of the Akchagylian), 2.1-2.0 Ma (base of the Apsheronian), 1.7 Ma (middle part of the Apsheronian), and two intervals within the Brunhes chron: upper Bakunian and lower Khazarian. Each of these intervals is closely related to the occurrence of new mollusc and microfauna taxa in the stratigraphic record that may be linked to the establishment of interbasinal connections of the Caspian Basin with the Arctic Ocean (for the base of Akchagylian) and with the Black Sea (for Apsheronian, Bakunian and Khazarian salinity increases).

High resolution dating of the biotic record in two palaeogeographically remote sections showed that first occurrence and further dispersion of the age-indicative molluscs is highly dependent on the depositional environments and in different parts of the basin may demonstrate diachronic occurrence. This implies high importance of the integrative approach in the evaluation of the regional boundaries.

\subsection{Acknowledgements}

We thank Tom Hoyle, Vusala Aghayeva, Rashad Amrahov, Sevinj Shiraliyeva, Gülçin Aygün and the research staff of the Geological and Geographic Institutes of the National Academy of Sciences of Azerbaijan for assistance in the field. We thank Guzel Danukalova for help with the Akchagylian cardiid identifications. The suggestions of three reviewers, including Imre Magyar, have been constructive to improve our manuscript. The research is part of the PRIDE project (Pontocaspian RIse and DEmise), which is funded by the European Union's Horizon 2020 research and innovation program, under the Marie Sklodowska-Curie (grant agreement № 642973). This paper is dedicated to the establishment of peace in the Caucasian region. 


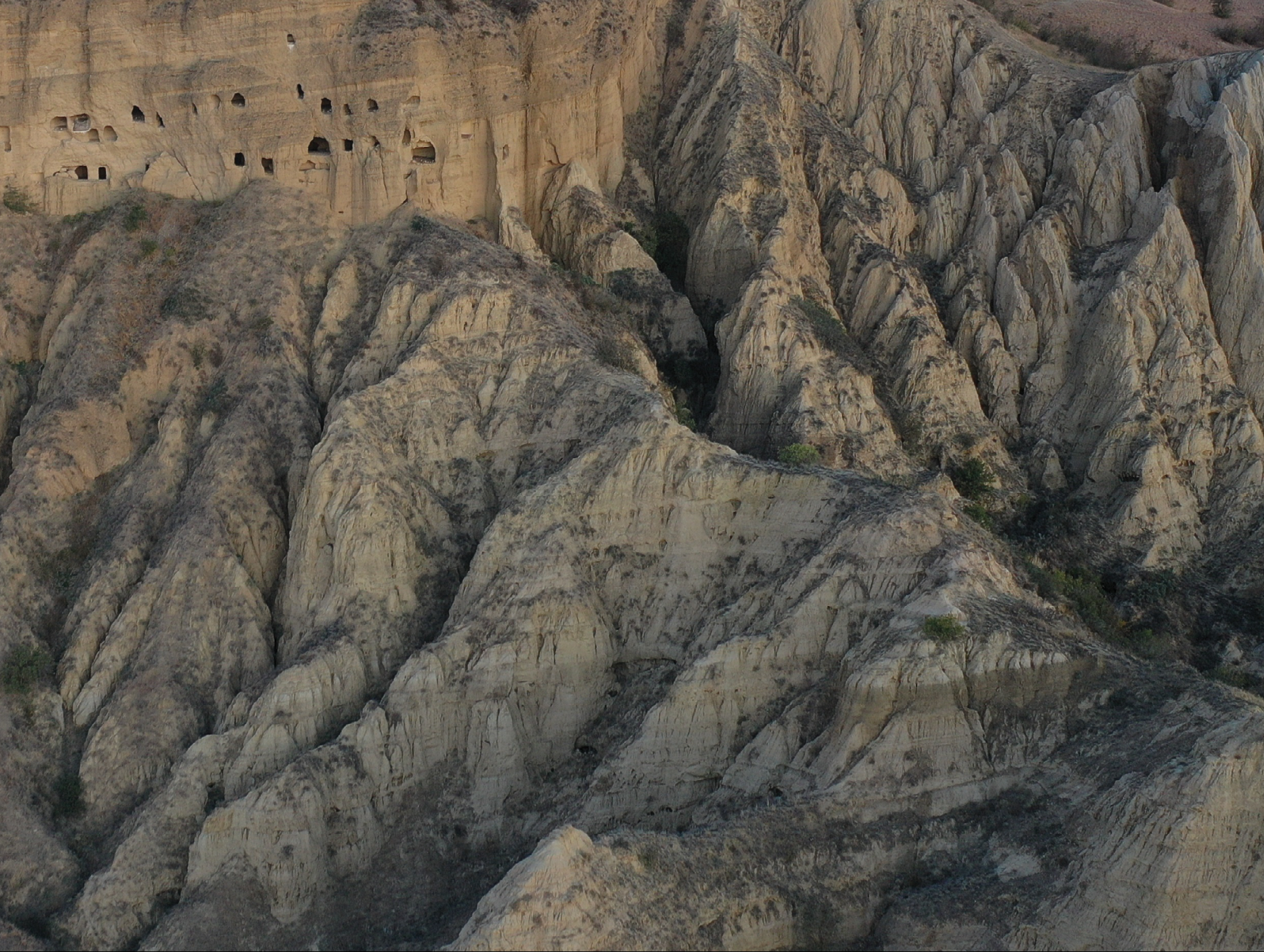

Akchagylian deposits of the Kvabebi section photographed with a drone. At the limit of a thrust. 


\section{The Plio-Pleistocene Akchagylian Flooding in the Westernmost Kura Basin (South Caspian Region): NeW AND REvised MAGNETOSTRATIGRAPHIC AGE CONSTRAINTS.}

In preparation:

S. Lazarev, O. Oms, M. Bukhsianidze, D. Vasilyan, K. Kuiper, M. L. Boumeester, E. L. Jorissen, V. Aghayeva, W. Krijgsman. The Plio-Pleistocene Akchagylian Flooding in the westernmost Kura Basin (South Caspian region): New and revised magnetostratigraphic and ${ }^{40} \mathrm{Ar} /{ }^{39} \mathrm{Ar}$ age constraints. 


\begin{abstract}
The Akchagylian flooding of the Caspian Basin, dated at $2.7 \mathrm{Ma}$, led to a fivefold increase of the Caspian surface water during the Plio-Pleistocene transition, which significantly influenced the palaeoenvironmental and palaeoclimatic conditions in Central Eurasia. Age discrepancies exist, however, with the fossil mammal-bearing sections on the western margin of the Kura Basin (SW Caspian Basin), where Akchagylian deposits have been magnetostratigraphically dated at 3.2 Ma. Here, we re-visit the Kvabebi (Georgia) and Kushkuna (Azerbaijan) sections of the westernmost Kura Basin and provide new magnetostratigraphic and ${ }^{40} \mathrm{Ar} /{ }^{39} \mathrm{Ar}$ age constraints on these marginal Akchagylian deposits. Our magnetostratigraphic results from both Kvabebi and Kushkuna reveal a single normal/ reversed polarity transition that we correlate to the Gauss-Matuyama boundary at the age of 2.6 Ma. New ${ }^{40} \mathrm{Ar} /{ }^{39} \mathrm{Ar}$ ages from the Hajigabul section confirm the Akchagylian stage is dated between 2.7 and 2.1 Ma. Depositional facies analysis of eight Akchagylian sections across a $\mathrm{W}-\mathrm{E}$ transect in the Kura Basin reveals the following series of successive palaeoenvironmental changes: 1) 2.7-2.5 (2.4) Ma onset of the Akchagylian flooding with marine faunal elements resulting from a Caspian - Arctic connection; 2) 2.5 (2.4)-2.1 Ma termination of the Arctic connection and a desalination change to oligohaline fauna in the Caspian Basin; and 3) 2.1 Ma ingression of Pontocaspian (Black Sea) mollusc fauna marking the Akchagylian-Apsheronian boundary. The new ages constrain a much shorter (2.7-2.1 Ma) Akchagylian than in previously mentioned regional geological time scales (3.6-1.8 Ma) and strongly appeal to reconsider the ages of numerous archaeological and mammalian sites in the south Caspian region.
\end{abstract}

\title{
5.1. Introduction
}

During the Pliocene-Quaternary, significant sea-level variations of several hundreds of meters have been inferred for the highly endorheic Caspian Basin (Popov et al., 2006; Krijgsman et al., 2019). A dramatic Pliocene base-level drop is expressed by the progradation of the palaeo-Volga delta into the South Caspian Basin (Fig. 5.1a), forming the massive hydrocarbon reservoirs of the Pliocene Productive Series in Azerbaijan (Reynolds et al., 1998; Kroonenberg et al., 2005; Abdullayev et al., 2012). These deltaic sands are subsequently sealed by the mostly fine-grained shale deposits of the Akchagylian stage. The so-called Akchagylian flooding is one of the most extreme events of sea-level rise in the Caspian Basin and increased the surface area of the Caspian Sea five-fold covering vast areas of southern Russia, Kazakhstan, Turkmenistan, Iran, Azerbaijan, and Georgia (Fig. 5.1). Recent palaeontological and geochemical investigations showed that this flooding was caused by the invasion of marine waters via a connection to the Arctic Ocean (Richards et al., 2018b; van Baak et al., 2019). Palynological analyses suggest that the transgression and lake expansion changed the climate and regional vegetation in the catchment area, especially by making late Pliocene glacial episodes milder (Hoyle et al., 2019b). 


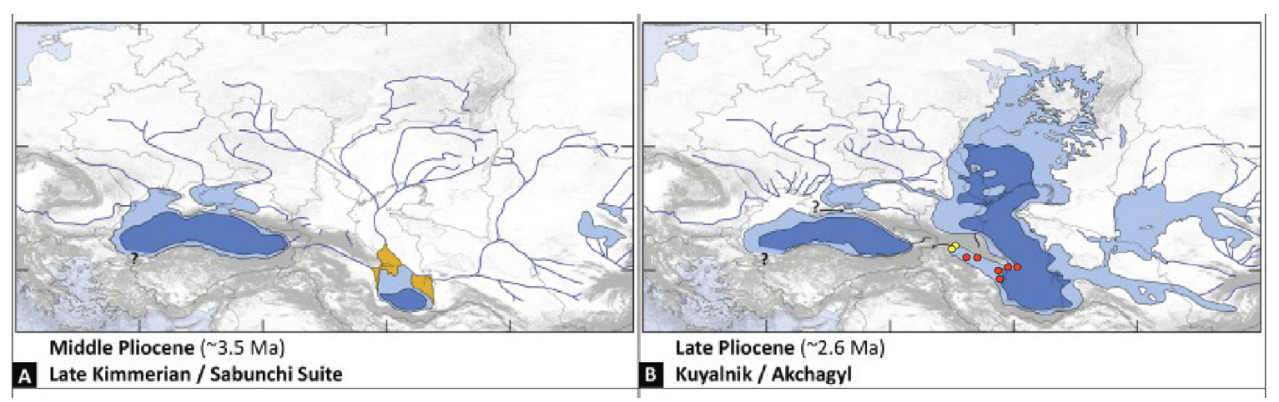

Fig. 5.1 Palaeogeographic reconstruction of the A) middle Pliocene and B) latest Pliocene-Early Pleistocene west Eurasian continental interior. After Krijgsman et al. (2019) based on maps by Vinogradov (1969) and Abdullayev et al. (2012). Yellow and red dots represent studied and revised locations, respectively. Dark blue colours represent deep water environments, light blue - shallow water environments, and orange - delta plains in the Pliocene Productive Series.

The Akchagylian flooding has now been robustly dated at $2.7 \mathrm{Ma}$, in several sections in the South Caspian Basin by a combination of magnetostratigraphy and ${ }^{40} \mathrm{Ar} /{ }^{39} \mathrm{Ar}$ datings (Hoyle et al., 2019b; van Baak et al., 2019). In most sections, the base of the Akchagylian is found in the top of a normal polarity interval that is correlative to the upper Gauss (C2An.1n) chron (Khramov, 1960, 1963; Lazarev et al., 2019; van Baak et al., 2019). Three volcanic ash layers from the lower part of the Akchagylian in the Jeirankechmez section, dated between 2.68-2.39 $\mathrm{Ma}$ (van Baak et al., 2019) and seven layers from the Lokbatan section dated between 2.73-2.60 (Hoyle et al., 2019b), confirmed this correlation and expressed the high volcanic activity in this time interval. The available age constraints indicate the flooding is a rapid event that occurred at the onset of Northern Hemisphere glaciations during the Plio-Pleistocene climate transition (van Baak et al., 2019).

All this is in significant contrast to the standard geological time scale used in Russian stratigraphy where the base of the Akchagylian stage is placed at 3.6 Ma (Nevesskaya et al., 2003; Nevesskaya et al., 2004; Gladenkov, 2018). This age is mainly based on the magnetostratigraphic correlation of the Pyrnuar section of the stratotype region (Krasnovodsk Peninsula) in western Turkmenistan (Trubikhin, 1977). Recently, however, the original correlation of the Pyrnuar polarity pattern was questioned by Gurarii (2015), who concluded a much younger age for the base of the Akchagylian, in agreement with other key-sections from Turkmenistan (Khramov, 1960, 1963; Krijgsman et al., 2019).

The Kvabebi section, located at the westernmost margin of the Kura Basin in Georgia, is another outlier to the young $\sim 2.7 \mathrm{Ma}$ age. This section is renowned for its rich large mammalian fossil fauna showing some African affinity and intercalated with strata comprising Akchagylian molluscs (Vekua, 1972; Agustí et al., 2009). The Kvabebi mammal site was magnetostratigraphically dated in a short reversed polarity interval attributed to C2An.1r 
(Kaena) providing the age of 3.07 Ma. Stratigraphically below, the Akchagylian mollusc fauna is found in the normal polarity interval, correlated to C2An.2n and dating back to almost $3.2 \mathrm{Ma}$ (Agustí et al., 2009). This correlation suggests that the Akchagylian fauna reached the western margin of the Kura Basin 0.5 Ma earlier than in deeper central parts, a scenario which strongly contradicts the flooding concept. This scenario is also in disagreement with the age constraints of the Sarica section in central Azerbaijan, where the base of the Akchagylian is estimated at the age of $2.5 \pm 0.2 \mathrm{Ma}$ (Forte et al., 2015). Two volcanic ash layers at the basal part of the Kvabebi section can be used to evaluate the age controversy. However, so far, no radio-isotopic age datings have been published from these tephras.

Here, we revisit and resample the Kvabebi section, reanalyse its palaeomagnetic data, and establish ${ }^{40} \mathrm{Ar} /{ }^{39} \mathrm{Ar}$ ages for the volcanic ash layers. For comparison, we also measure and analyse the Kushkuna section, located nearby across the border to Azerbaijan. This will provide new age constraints for the Akchagylian deposits of the westernmost Kura Basin, which we will discuss and compare with the literature data of six further sections (Duzdag, Goycay, Hajigabul, Jeirankechmez, Babazanan and Lokbatan) that together make a W-E transect across the entire Kura basin.

\subsection{Geological setting}

\subsubsection{The Kura Basin}

The Kura Basin is a former sub-basin of the southwest Caspian Sea Basin (Fig. 5.2). This embayment has a north-west to south-east orientation and corresponds to the foreland basins of both the Greater Caucasus in the north and the Lesser Caucasus in the south. The Greater Caucasus is an $850 \mathrm{~km}$ long NW-SE striking mountain range and forms the northern margin of the basin. It extends eastward into the Caspian Sea, where it forms the Apsheron sill between the Middle and South Caspian basins. Further southeast, the ridge extends into the Kopet-Dag range of West Turkmenistan.

The Caucasus mountain ranges formed during an orogenic episode following the continentcontinent collision of Africa-Arabia and Eurasia initiated during the Oligocene (Vincent et al. 2007). This resulted in an inversion of the back-arc basin that preceded the Greater Caucasus (Saintot et al., 2006), the active basin margin preceding the Lesser Caucasus and numerous island-arc and rift basins of the neo-Tethys (Kazmin et al., 2000; Sosson et al., 2017). The inversion also produced the fold and thrust belts associated with the foreland Kura Basin (Fig. 5.2).

The Kura fold and thrust belt is a thin-skinned deformation belt extending southwards from the Greater Caucasus that was initiated during the Pliocene-Pleistocene, although the exact timing and evolution remain not fully resolved (Forte et al., 2013). The region has accommodated $30-40 \%$ of all convergence between Arabia and Eurasia (Forte et al., 2010). It 


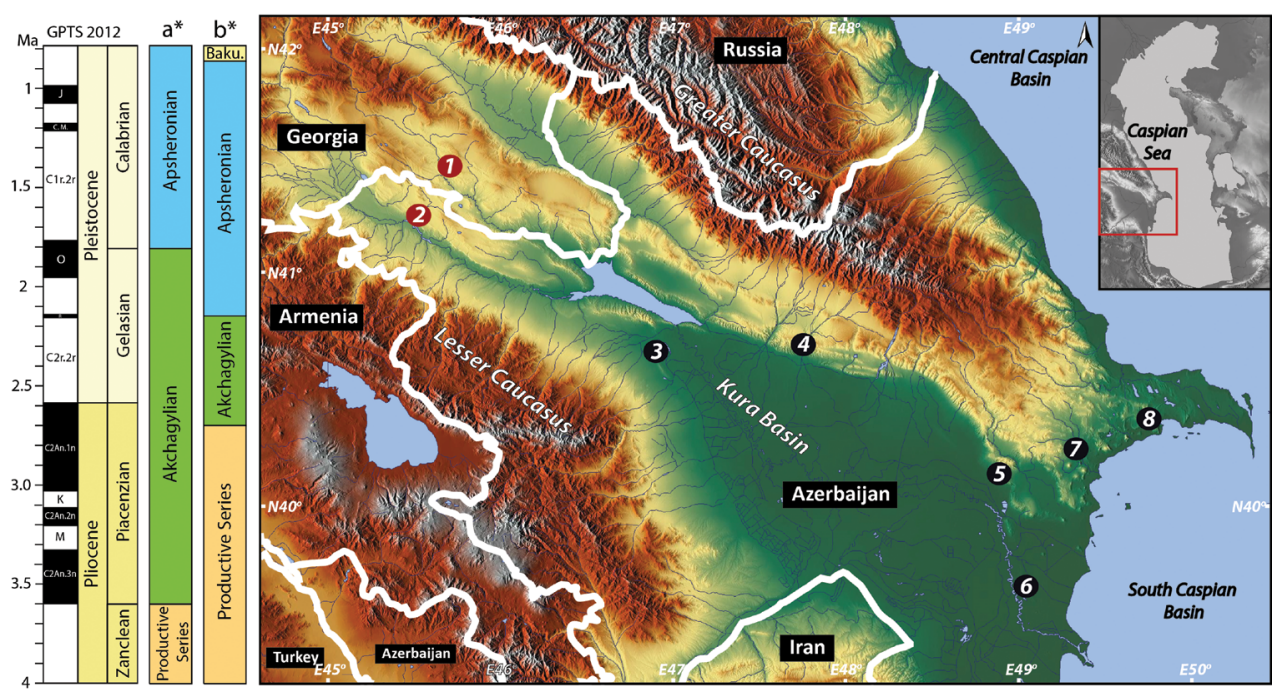

Figure 5.2. Location map of studied ( 1 - Kvabebi, 2 - Kushkuna) and revised (3 - Duzdag, 4 - Goychay, 5 - Hajigabul, 6 - Babazanan, 7 - Jeirankechmez, 8 - Lokbatan) localities across the Kura Basin. Columns on the left: Geomagnetic polarity time scale (GPTS 2012), Epoch/Age, regional stages (Hilgen et al., 2012). Regional Stages: $a^{*}$ classical definition (Shantser, 1982; Arslanov et al., 1988; Nevesskaya et al., 2003; Gladenkov, 2018), b* (Lazarev et al., 2019; van Baak et al., 2019). The map base is taken from www.mapsfor-free.com.

features south-verging thrusts and opposite back-thrusts that fold the overlying Kura Basin sediments. Deformation in the foreland fold-thrust belt initiated in the western part during or prior to the Akchagylian, after which deformation shifted eastwards (Forte et al., 2015; Sosson et al., 2017). The deformation weakens southwards (Sosson et al., 2017). The nature of its northern limit is controversial. Both north- and south-dipping thrusts have been interpreted, and the underlying kinematics of mapped structures are often inconsistent. Active structures feature E-W striking compressive, NW-SE striking dextral, and NE-SW striking sinistral strike-slip faults (Forte et al., 2015; Alania et al., 2017).

The Kura Basin is infilled with up to $13 \mathrm{~km}$-thick sedimentary successions in its depocentre (Brunet et al., 2003; Abdullayev et al., 2012). The Pliocene-Pleistocene Akchagylian regional stage represents mainly mudstones in its deepest parts (Lazarev et al., 2019) and continental deposits with terrestrial mammal remains in its western extremity (Agustí et al., 2009). The overlying Early Pleistocene Apsheronian regional stage is marked in the centre by alternating offshore mudstones, coastal sandstones, and terrestrial mudstones enriched in brackish and freshwater faunas (Jorissen et al., 2019; Lazarev et al., 2019). These conditions highlight shallower environmental settings compared to the Caspian Sea. 


\subsubsection{Kvabebi section (Georgia)}

The Kvabebi section crops out on a hillside near the Iori River, $17 \mathrm{~km}$ southwest from the hamlet of Kvemo Bodbe in the Kakheti region of Eastern Georgia (Fig. 5.2, 5.3). Here, the Akchagylian deposits transgressively overlie late Miocene continental conglomerates (Shirak Suite). The upper parts are bounded by a thrust fold (Ali-Zade et al., 1972). The Kvabebi section is known for its vertebrate fossil faunas attributed to the Ruscinian-early Villafranchian, late Pliocene-Pleistocene (Vekua, 1972; Agustí et al., 2009). The Akchagylian age of the site has been defined by the presence of indicative Akchagylian molluscs like Avimactra subcaspia, Cerastoderma (Cardium) dombra (Djikia, 1968).

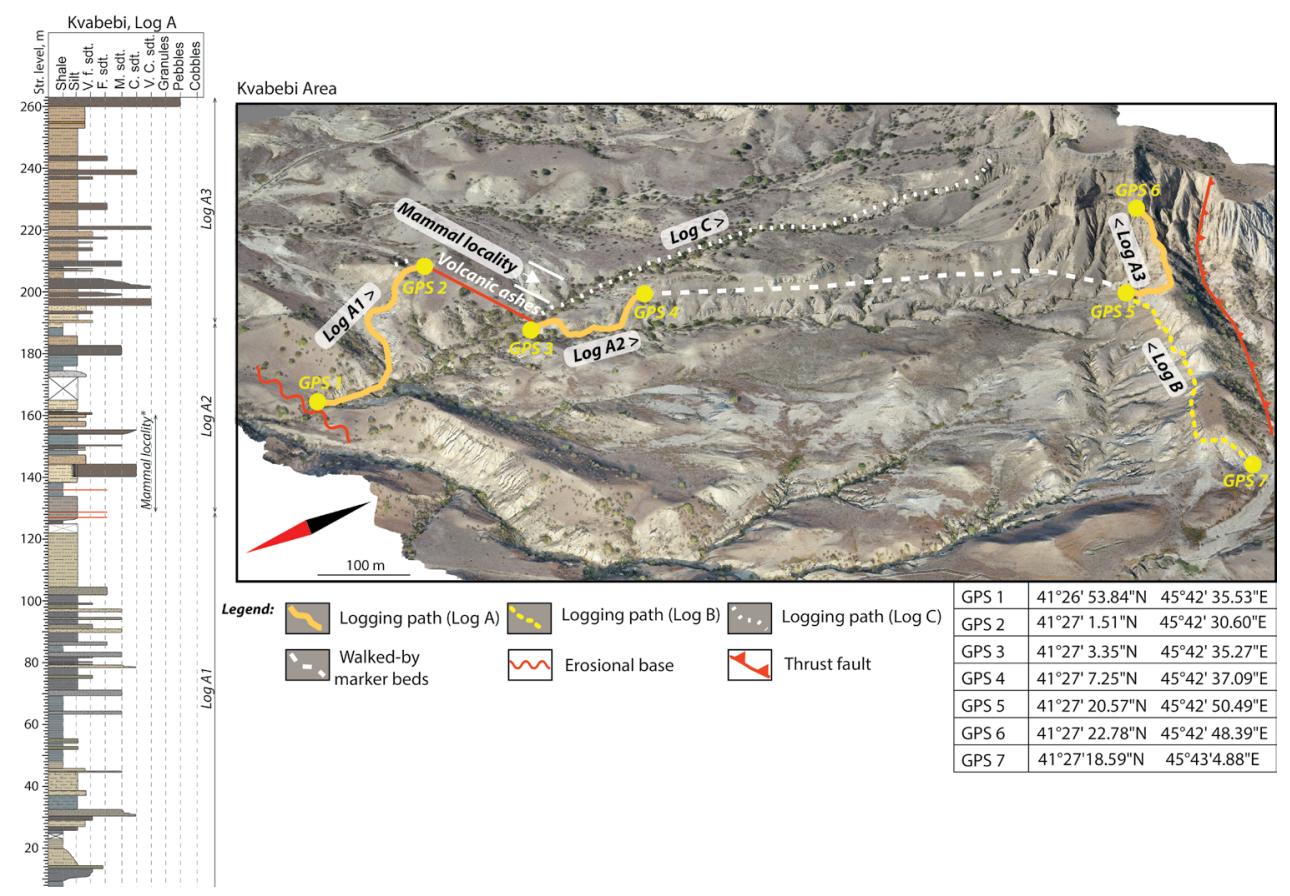

Figure 5.3. Composite Log A and 3D model of the Kvabebi locality with indication of logging paths and GPS coordinates.

\subsubsection{Kushkuna section (Azerbaijan)}

The Kushkuna section is located $20 \mathrm{~km}$ north of the town Aghstafa in western Azerbaijan, in the sand-quarry near the Ceyrançöl village (Fig. 5.2, 5.4). The section is exposed in the NE wing of the anticline whose hinge is gently plunging to $127^{\circ} \mathrm{SE}$. Here, the late Miocene greywacke sandstones are transgressively overlain by Akchagylian claystones. The previously described $400 \mathrm{~m}$-thick section was built up of two distinct parts. The lower $220 \mathrm{~m}$ contains characteristic Akchagylian mollusc fauna with Cerastoderma (Cardium) dombra, Avimactra subcaspia, 


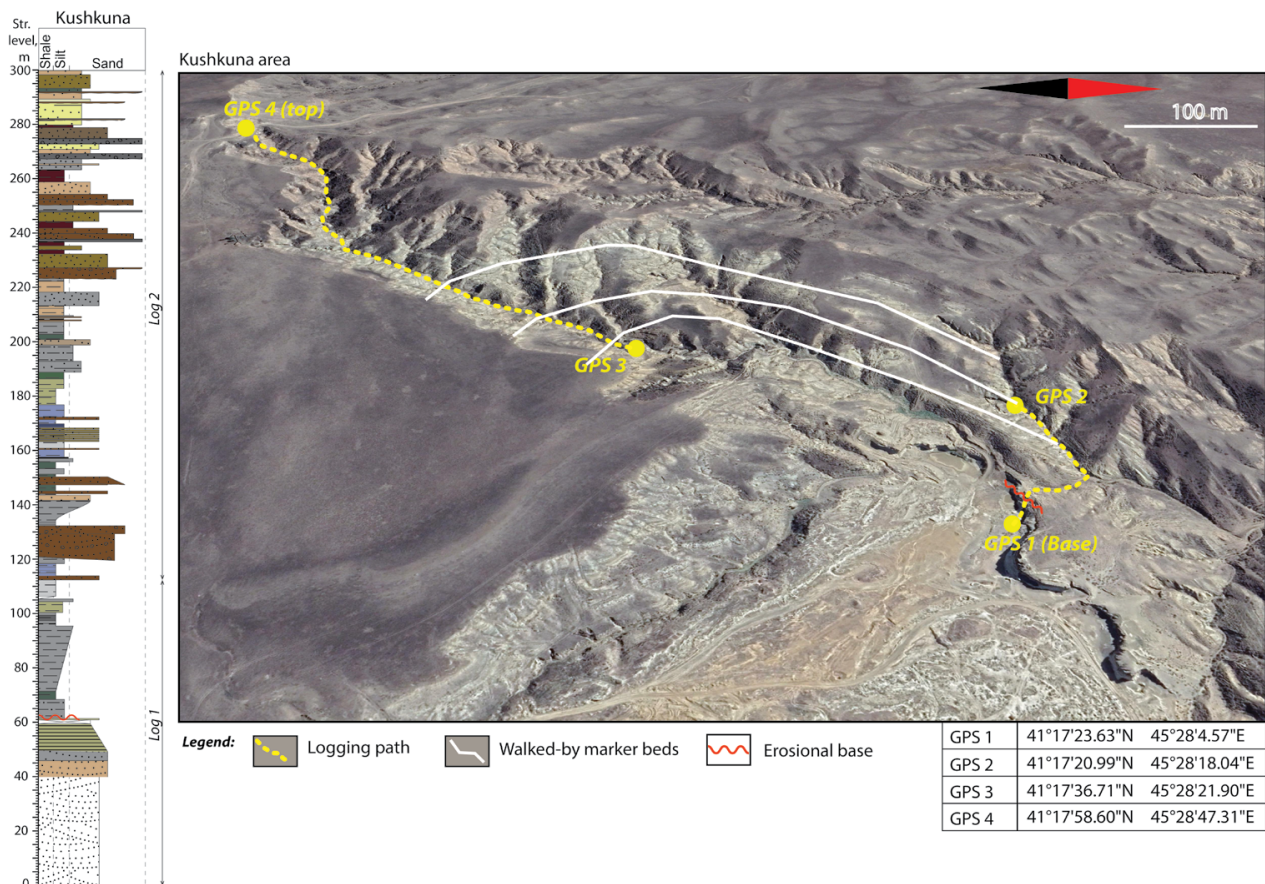

Figure 5.4 Composite log and aerial photo (Google Earth) of the Kushkuna locality with the indication of logging paths and GPS coordinates.

Potamides caspium (Lebedeva, 1972). The upper $180 \mathrm{~m}$ comprise continental sandstones and palaeosols that were attributed to an undetermined Akchagylian-Apsheronian age (Ali-Zade et al., 1972; Lebedeva, 1972; Tesakov, 2004). Remains of large and small mammalian faunas from the lower part of the section are attributed to the Villanyian and the MN 16b zone ( 3.0-2.5 Ma) (Lebedeva, 1972; Tesakov, 2004). A previous magnetostratigraphic study of the section revealed a single polarity transition from a normal in the lower part to a long reversed interval in the upper part of the section. Earlier this polarity change was correlated to the GaussMatuyama boundary at the age of 2.6 Ma (Zubakov and Kochegura, 1976).

\subsection{Methodology}

\subsubsection{Logging}

The stratigraphic thicknesses have been measured using the portable Jacob's staff. During logging, basic observations on the colour, lithology, sedimentary structures, and faunal content of the beds have been documented.

The Akchagylian deposits in Kvabebi area are well-exposed along numerous gullies. For better coverage of the section and correlation with existing studies, we logged the Kvabebi 
section along three transects. Moreover, the area has been photographed using a drone, and consequently, high-resolution 3D model of the site has been built (Fig. 5.3). The first, 263 $\mathrm{m}$-thick transect named Log A covers the entire section in N-NE direction, from the contact of Akchagylian claystones with late Miocene conglomerates at the base (GPS 1, Fig. 5.3) to the top of the section, where Akchagylian conglomerates are delimited by thrust fold (GPS 6, Fig. 5.3). The second, $167 \mathrm{~m}$-thick transect called $\log \mathrm{B}$ stretches out in SE-NW direction and starts directly with Akchagylian claystones (GPS 7, Fig. 5.3). The Log C is a $172 \mathrm{~m}$-thick succession previously published by Agustí et al., 2009. Both Log A and Log C overlap in the area of the mammalian locality.

The Kushkuna section has been logged along two separate transects. The lower part is 110 $\mathrm{m}$-thick and covers the uppermost part of the underlying late Miocene greywackes $(0-60 \mathrm{~m})$ and the basal part of Akchagylian clay- and siltstones (60-110 m, Fig. 5.4). The upper part of the section (110-260 $\mathrm{m}$ ) has been logged in a neighbouring valley after a connection was established by tracing some laterally extensive sandstone beds (Fig. 5.4).

\subsubsection{Magnetostratigraphy}

From the Kvabebi section, in total 37 samples were selected for thermal demagnetisation (th) and 91 samples for alternating field (af) demagnetisation measurements. In addition, we also re-measured 32 doublet samples from the previously published sampling set of Agustí et al., 2009. From the Kushkuna section, 38 samples were thermally measurements and 23 samples by alternating fields. All measurements have been performed in the Paleomagnetic laboratory "Fort Hoofddijk", Utrecht following the methodology of Lazarev et al. (2019).

\subsection{3. ${ }^{40} \mathrm{Ar} /{ }^{39} \mathrm{Ar}$ isotope dating}

Three volcanic ash layers have been sampled in the field, one from the base of the Kvabebi section (KVB-1, 129 m, Fig. 5.3) and two ash layers from the Hajigabul section in the eastern Kura Basin: HG-4 (194.5 m) and HG-1033 (1030 m) (Fig. 8 in Lazarev et al., 2019). Minerals from these ash layers were separated using standard mineral separation procedures. After crushing and washing of the samples, heavy liquid mineral separation with densities of 2.54 and $2.59 \mathrm{~g} / \mathrm{cm}^{3}$ was performed to obtain the sanidine phenocrysts from the samples. For KVB-1 also biotite was separated. Mineral fractions were further purified by hand-picking under an optical microscope. The selected mineral separates were packed in a $6 \mathrm{~mm}$ ID AI packages (aluminium). They were loaded together with Fish Canyon Tuff sanidine (FCs) standards in $25 \mathrm{~mm}$ ID Al cups. Samples and standards were irradiated at the Oregon State University TRIGA reactor in the cadmium shielded CLOCIT facility for 12.6 hours (irradiation code VU117; equivalent to 7 hours of CLICIT position). After irradiation samples and standards were unpacked and loaded in a 185 -hole $\mathrm{Cu}$ tray and baked overnight at $250^{\circ} \mathrm{C}$ under vacuum. This tray is then placed in a doubly pumped vacuum chamber with $\mathrm{Zn}$-Se window and baked 
overnight at $120^{\circ} \mathrm{C}$ under high vacuum. This chamber is connected to a ThermoFisher NGPrep gas purification line equipped with a hot GP50, a cold finger (Lauda at $-70{ }^{\circ} \mathrm{C}$ ) and hot St707 getter.

Samples and standards were measured in two different trays $(19 \mathrm{~T} 13 ; 19 \mathrm{~T} 14)$. In the first tray, we exposed the feldspar phenocrysts to a diffuse laser beam under UHV conditions to drive off surficial gasses. The released gas during this pre-heating steps was not measured, but based on previous tests should not contain $>1 \%$ of the ${ }^{39} \mathrm{Ar} / \mathrm{K}$ released. Samples and standards are fused using a $25 \mathrm{~W}$ Synrad $\mathrm{CO}_{2}$ laser. The released gas is analysed on an ARGUS VI+ noble gas mass spectrometer at the Vrije Universiteit Amsterdam. This is a high sensitivity, relatively low resolution multi-collector noble gas mass spectrometer with an internal volume of $710 \mathrm{ml}$. The resolution of the system is $\sim 200$ and therefore does not resolve hydrocarbon or chlorine interferences. The mass spectrometer is equipped with four Faraday cups at the H2, H1, AX, and L1 positions and two compact discrete dynodes (CDDs) at positions L2 and L3. The system is equipped with a 10E12 Ohm amplifier on $\mathrm{H} 2$ and 10E13 Ohm amplifiers on H1, AX and L1 cups. Samples were run on H1-L3 collectors. Similar to Phillips and Matchan (2013), we did not apply bias corrections but analysed samples and standards in the same tray (and thus at more or less the same time) alternating with air pipettes with intensities in the same range as the samples and standards. Line blanks were measured every 2-3 unknowns and were subtracted from succeeding sample data.

Data reduction is made in ArArCalc (Koppers, 2002). Ages are calculated with (Min et al., 2000) decay constants and 28.201 Ma for FCs (Kuiper et al., 2008). The atmospheric ${ }^{40} \mathrm{Ar} /{ }^{36} \mathrm{Ar}$ air value of 298.56 is used (Lee et al., 2006). The correction factors for neutron interference reactions are $(2.64 \pm 0.02) \times 10^{-4}$ for $\left({ }^{36} \mathrm{Ar} /{ }^{37} \mathrm{Ar}\right) \mathrm{Ca},(6.73 \pm 0.04) \times 10^{-4}$ for $\left({ }^{39} \mathrm{Ar} /{ }^{37} \mathrm{Ar}\right) \mathrm{Ca},(1.21 \pm$ $0.003) \times 10^{-2}$ for $\left({ }^{38} \mathrm{Ar} /{ }^{39} \mathrm{Ar}\right) \mathrm{K}$ and $(8.6 \pm 0.7) \times 10^{-4}$ for $\left({ }^{40} \mathrm{Ar} /{ }^{39} \mathrm{Ar}\right) \mathrm{K}$. All errors are quoted at the $1 \sigma$ level. All relevant analytical data for age calculations can be found in the appendix.

\subsection{Results}

\subsubsection{Magnetostratigraphy of the Kvabebi section}

Demagnetization of 146 samples from Kvabebi reveals the presence of two magnetic components. The first magnetic component is a low temperature / low-intensity component that is almost exclusively present in samples of normal polarity. This component is observed in $53 \%$ (51 out of 93) of the alternating field (af) demagnetization diagrams where it ranges between $0-25 \mathrm{mT}$, and in $25 \%$ (14 out of 55) of the thermally demagnetised samples (th) in a temperature range of $20-270^{\circ} \mathrm{C}$ (Fig. 5.5A). The mean directions for both, low temperature (LTC) and low intensity (AF_1) groups are statistically indistinguishable and are consequently combined in one common "1st component" group (Fig. 5.5B). The mean direction of this component in geographic coordinates has parameters of $\mathrm{D}=7.4^{\circ}, \mathrm{I}=60^{\circ}, \mathrm{k}=13.1^{\circ}, \alpha 95=4.5^{\circ}$ 


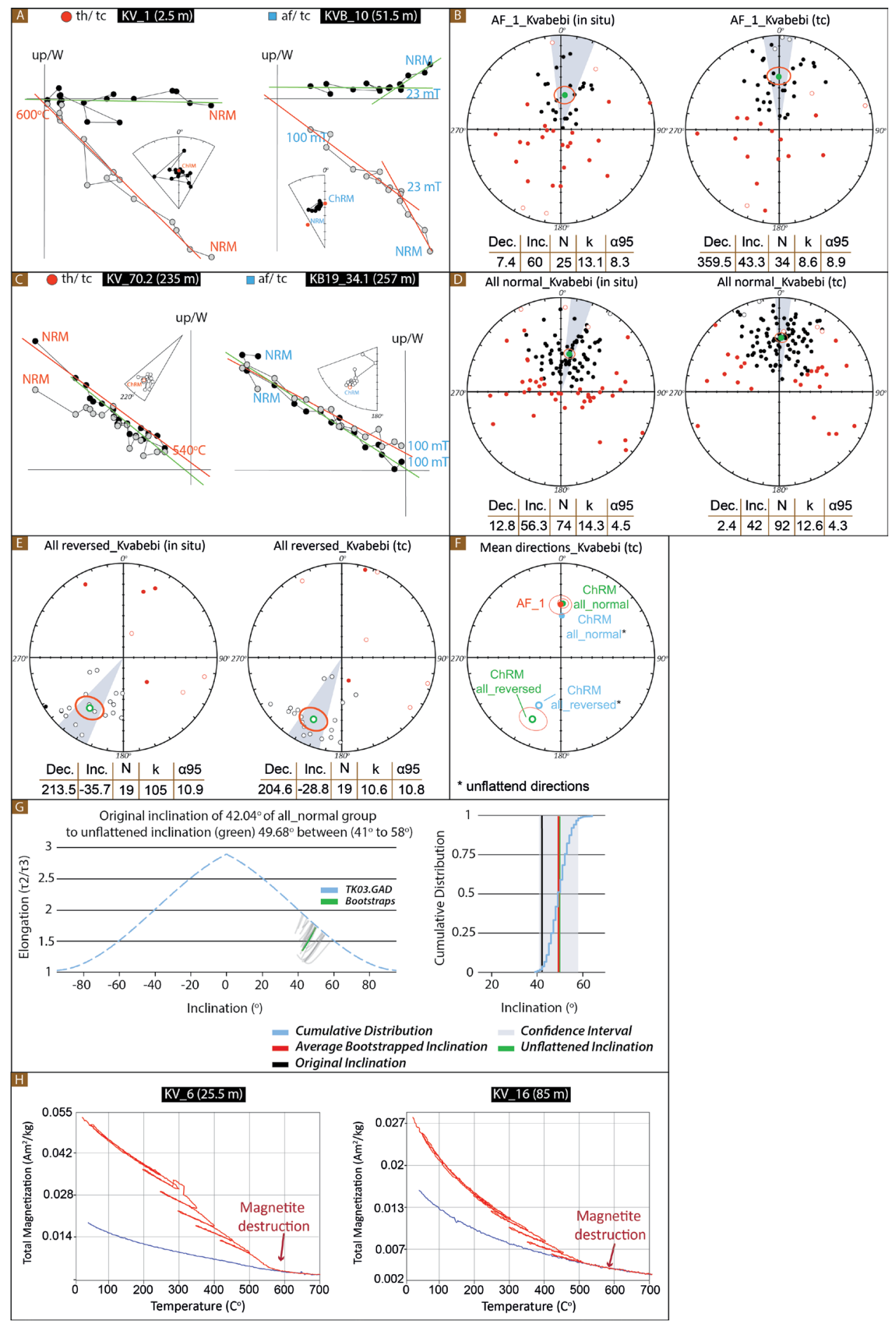


Figure 5.5 (previous page). Zijderveld diagrams, area plots, and thermomagnetic curves for samples of the Kvabebi section. Zijderveld diagrams for: A. normal samples, C. reversed samples. Equal are plots of the: B. Low-intensity 1st component; D. All normal (high temperature and high-intensity components); E. All reversed (high-temperature and high-intensity components). F. Mean directions of all determined magnetic components; G. Bootstrap test curve showing the inclination shallowing in "All normal" group; $\mathrm{H}$. Thermomagnetic run curves with magnetite being interpreted as the main magnetic carrier. Abbreviations: in situ - geographic coordinates; tc - tectonically corrected coordinates, NRM - Natural remanent magnetisation, ChRM - Characteristic remanent magnetisation, Dec. - declination, Inc. inclination, $\mathrm{N}$ - number of statistically accepted samples, $\mathrm{k}$ - precision parameter of Fischer (1953), a95 - $95 \%$ cone of confidence.

for $\mathrm{N}=34$ and $\mathrm{D}=359.5^{\circ}, \mathrm{I}=43.3^{\circ}, \mathrm{k}=8.6^{\circ}, \alpha 95=8.9^{\circ}$ for $\mathrm{N}=43$ in tectonic coordinates (Fig. $5.5 \mathrm{~B})$.

The second magnetic component unblocks at a maximum temperature of $600^{\circ} \mathrm{C}$ in th-diagrams and at $100 \mathrm{mT}$ in af-diagrams (Fig. 5.5A). It is uniformly present in most of the studied samples and has both normal and reversed polarities (Fig. 5.5A, C). Thermomagnetic runs show concave or slightly convex curves that indicate a gradual decay to $600^{\circ} \mathrm{C}(\mathrm{Fig}$. $5.5 \mathrm{H})$. Such behaviour is characteristic for magnetite that has a Curie temperature of $580^{\circ} \mathrm{C}$, which is thus considered to be the main magnetic carrier in the Kvabebi samples.

The mean directions acquired with both af- and th-techniques are statistically indistinguishable and are combined into "all_normal" (Fig. 5.5D) and "all-reversed" groups (Fig. 5.5E). The mean direction for the "all normal" group in tectonic coordinates has parameters of $\mathrm{D}=2.4^{\circ}, \mathrm{I}=42^{\circ}, \mathrm{k}=12.6^{\circ}, \alpha 95=4.3^{\circ}$ for $\mathrm{N}=92$ and for the "all_reversed" group these are $\mathrm{D}=204.6^{\circ}, \mathrm{I}=-28.8^{\circ}, \mathrm{k}=10.6^{\circ}, \alpha 95=10.8^{\circ}$ for $\mathrm{N}=19$ (Fig. 5.5D, 5.5E).

The mean directions of the "1st component" and the "all_normal" component have very similar declination and inclination values in both geographic and tectonic coordinates (Fig. 5.5F). The bootstrap test (Tauxe et al., 2010) shows that the two groups fall within the 95\% confidence interval and are statistically indistinguishable. Thereby, the two magnetic components may either represent a primary characteristic remanent magnetization (ChRM) and/or a secondary viscous present-day overprint. Most strata in Kvabebi have a dip direction of $350-0^{\circ} \mathrm{NNW}$ with a tilt of $25^{\circ}$ indicating that inclination values can be used to distinguish between potential magnetic overprint and ChRM directions.

The expected inclination for the Kvabebi location is $\mathrm{I}=66.5^{\circ}$ according to the geocentric axial dipole (GAD) for this latitude, which is nearly identical to the inclination of both groups in geographic coordinates. The inclination of both groups in tectonically corrected coordinates is $42^{\circ}$, too shallow compared to the expected inclination. To test for potential inclination shallowing, we applied the elongation/inclination (E/I) test of Tauxe and Kent (2004) that fits observed inclinations to the TK03.GAD Field Model using the flattening function 


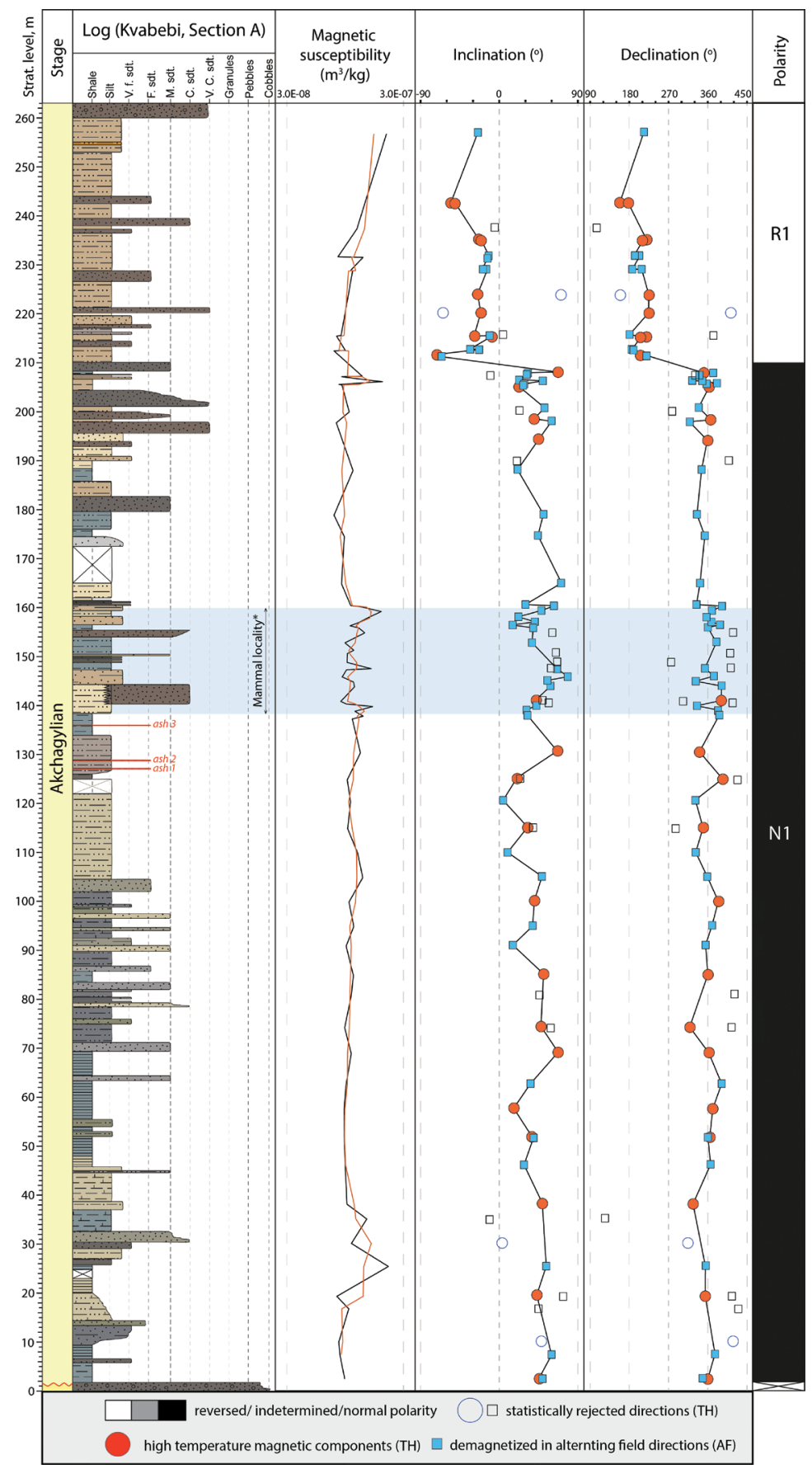

Figure 5.6 Composite sedimentary log A and magnetostratigraphy of the Kvabebi section. Magnetic susceptibility is plotted on a logarithmic scale: black line - for every sample, red line - averaged by 3 . 
of King (1955). The bootstrap test used in the E/I method shows an average unflattened mean inclination of $49.68^{\circ}$ for the "all_normal" group (Fig. 5.5G), while the application of this method to the "1st component" group did not find intersections with the TK03.GAD polynomial (negative test). Application of this method to the "all-reversed" group also revealed an inclination shallowing of about $10^{\circ}$, but considering the small number of samples (19 against 80 recommended for the test), these results remain quite speculative. The E/I method shows that high-temperature/high-intensity groups "all-reversed" and "all normal" underwent significant inclination shallowing, and thus, we interpreted these groups as primary directions. The reversal test of McFadden and McElhinny (1990) applied for both "all_reversed" and "all_ normal" groups is negative. This might be caused by the interference of primary and secondary components. The low-temperature/low-intensity directions of the "1st component" group show no sign of inclination shallowing are interpreted as viscous overprints.

Plotting all results in stratigraphic order reveals only two polarities in $\log \mathrm{A}$, the lower part $(0-210 \mathrm{~m})$ is of normal polarity $(\mathrm{N} 1)$, the upper part $(210-260 \mathrm{~m})$ shows reversed polarities
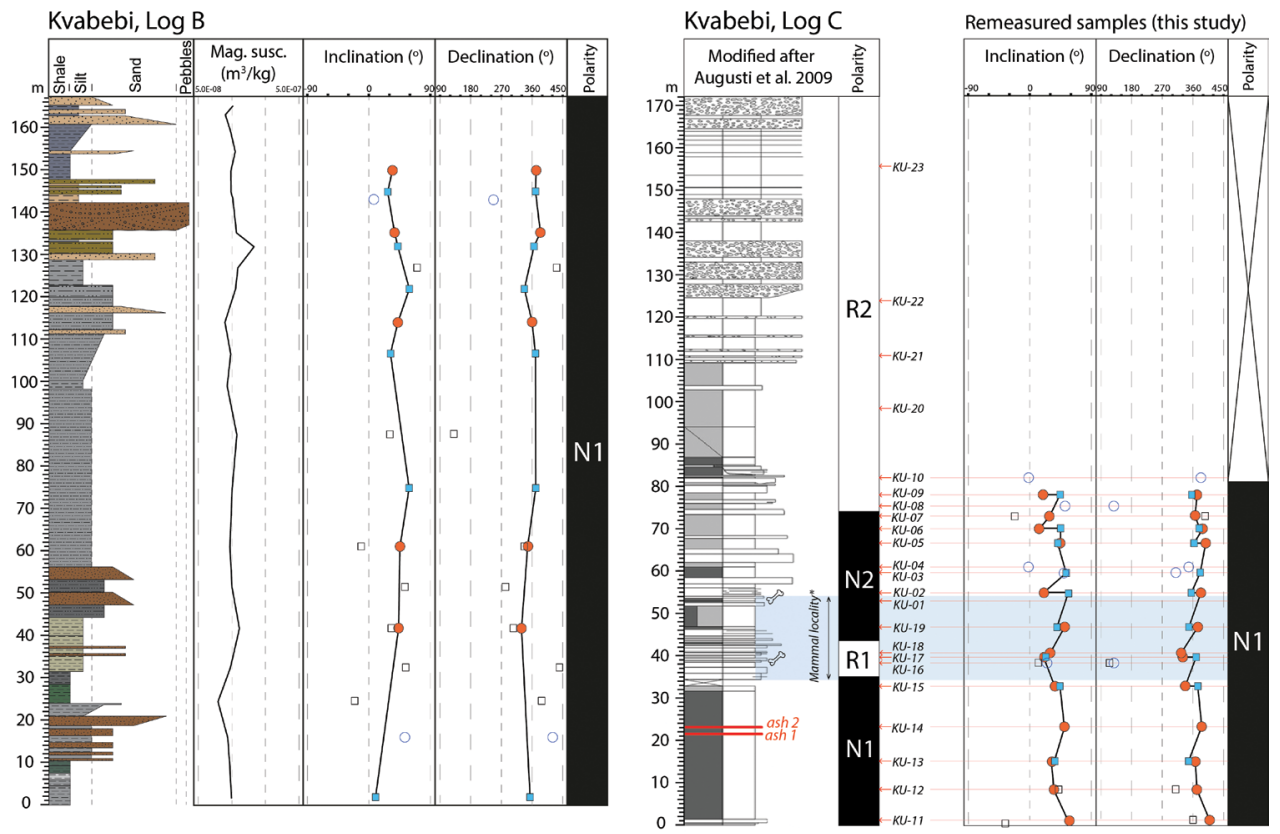

Figure 5.7. Sedimentary logs and magnetostratigraphy along transects B and C in Kvabebi area. In the Log C, the lithological column with adjacent polarity patterns and sampling points represent published data by Agustí et al., 2009, while polarity patterns on the right are new data of this study. 
(R1) (Fig. 5.6). Log B contains only normal polarity (N1, Fig. 5.7). Measurements of doublets from the Log C also revealed only normal polarities (N1, Fig. 5.7).

\subsubsection{Magnetostratigraphy of the Kushkuna section}

Demagnetisation of 61 samples from the Kushkuna section using thermal (th) and alternating field (af) demagnetization also shows the presence of two magnetic components.

In th-samples, the first component is again a low-temperature component in the temperature range $20-270^{\circ} \mathrm{C}$. It is present in $80 \%$ of all thermally demagnetised samples (Fig. $5.8 \mathrm{~A})$. In af-samples, the first component represents low-intensity components developed in the range $0-20 \mathrm{mT}$, and is present in $60 \%$ of all samples (Fig. 5.8A). Combining directional data of both th and af samples into a unified "1st component" group yields a mean direction of $\mathrm{D}=0.7^{\circ}, \mathrm{I}=65^{\circ}, \mathrm{k}=17.5^{\circ}, \alpha 95=7.83^{\circ}$ for $\mathrm{N}=21$ in geographic coordinates (Fig. $5.8 \mathrm{~B}$ ). The expected inclination for the Kushkuna area is $\mathrm{I}=66.5^{\circ}$. We, therefore, interpret the first magnetic component in the Kushkuna section as a viscous overprint as well.

The second component displays both normal and reversed polarities and demagnetizes in a temperature range $290-580^{\circ} \mathrm{C}$ in th-samples and $20-80 \mathrm{mT}$ in af-samples (Fig. $5.8 \mathrm{~A}, 5.8 \mathrm{C}$ ). The bootstrap test shows that the mean direction for th- and af-samples overlap within $95 \%$ confidence interval and they were combined into two groups: "all reversed" and "all normal". The mean direction for "all reversed" in tectonic coordinates has parameters of $\mathrm{D}=188.4^{\circ}, \mathrm{I}=$ $-41.5^{\circ}, \mathrm{k}=11.7^{\circ}, \alpha 95=10.9$ for $\mathrm{N}=17$ (Fig. 5.8D) and for “all_normal” $\mathrm{D}=5.4^{\circ}, \mathrm{I}=58.4^{\circ}, \mathrm{k}=$ $29.1^{\circ}, a 95=4.9^{\circ}$ for $\mathrm{N}=31$ (Fig. $5.8 \mathrm{E}$ ).

The acquired inclination values of $-41.4^{\circ}$ and $58.4^{\circ}$ are again significantly shallower compared to the expected $\mathrm{I}=66.5^{\circ}$ of the geocentric axial dipole $(\mathrm{GAD})$ for this area. The small number of samples, unfortunately, do not allow the application of the E/I shallowing inclination test. The reversal test of McFadden and McElhinny (1990) applied for these groups is positive, and, thus, the high-temperature/high-intensity magnetic component is interpreted as characteristic for the sedimentation age (ChRM).

The magnetostratigraphic patterns of the Kushkuna section consist of one normal polarity zone $(\mathrm{N} 1,60-201 \mathrm{~m})$ and one reversed zone (R1, 223-300 m) separated by a short interval of undetermined polarity (201-223 m, Fig. 5.9).

\subsection{3. ${ }^{40} \mathrm{Ar} /{ }^{39} \mathrm{Ar}$ dating}

For KVB-1, we analysed both the sanidine and biotite fractions. In tray 19T13, we fused 5 grains/hole and in tray 19T14 7-10 grains/hole for the biotite and 5 and 15 grains/hole respectively for the sanidine. The average radiogenic ${ }^{40} \mathrm{Ar}$ yield for biotite is $\sim 40 \%$ (irrespective if samples were preheated in UHV, or not). Ages range from 2.97 to $2.76 \mathrm{Ma}$. If we select the weighted mean age, including the highest number of analyses with overlapping ages and MSWD $<$ t-test statistics at $95 \%$ confidence level, the weighted mean age arrives at $2.864 \pm 0.008 \mathrm{Ma}$. 


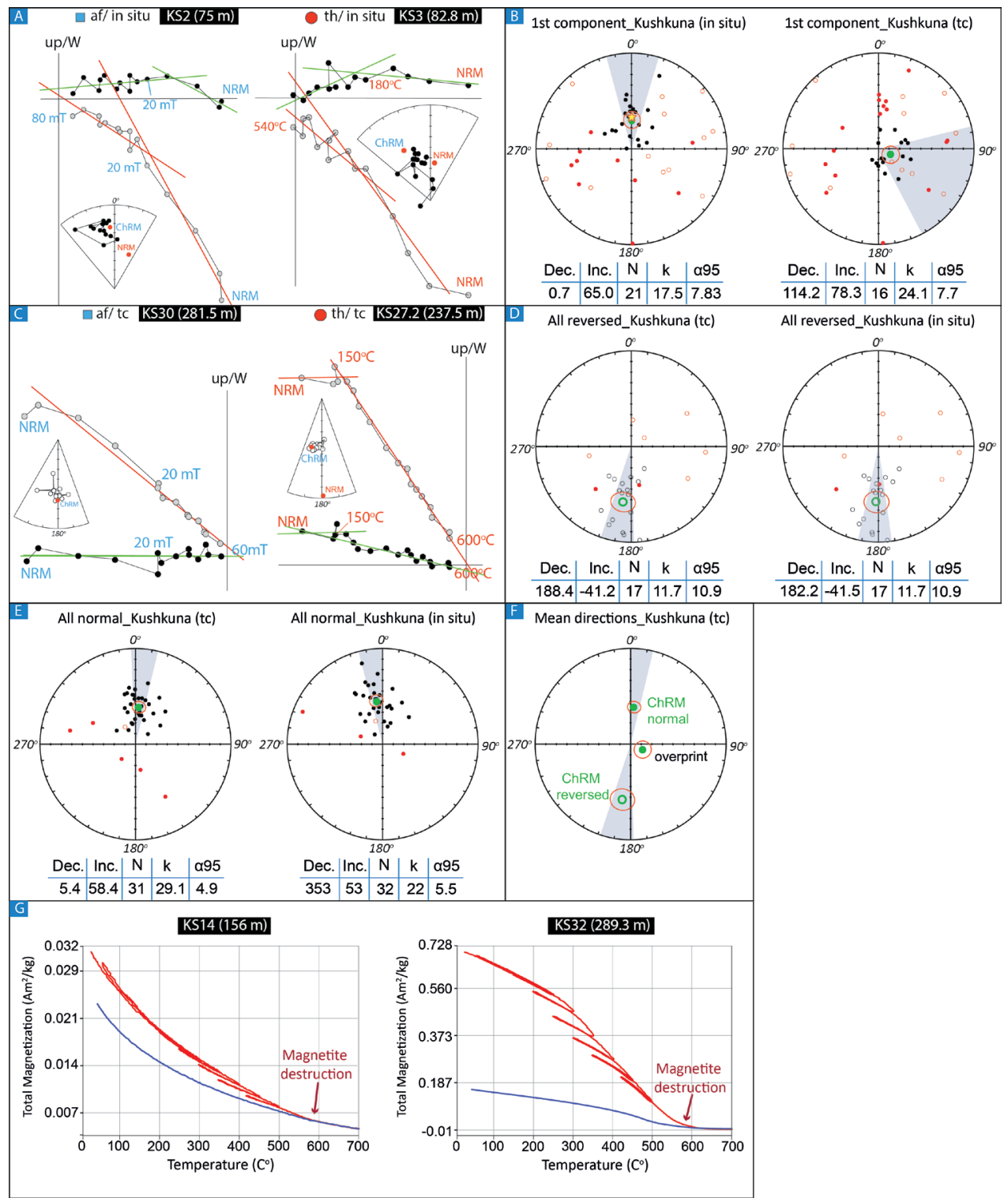

Figure 5.8 Zijderveld diagrams, area plots, and thermomagnetic curves for samples of the Kushkuna section. Zijderveld diagrams for: A. normal samples, C. reversed samples. Equal are plots of the: B. 1st component (combined low temperature and low intensity); D. All reversed (high-temperature and high-intensity components); E. All normal (high temperature and high-intensity components). F. Mean directions of all determined magnetic components; G. Thermomagnetic run curves with magnetite being interpreted as the main magnetic carrier. Abbreviations are given in Figure 5.5. 


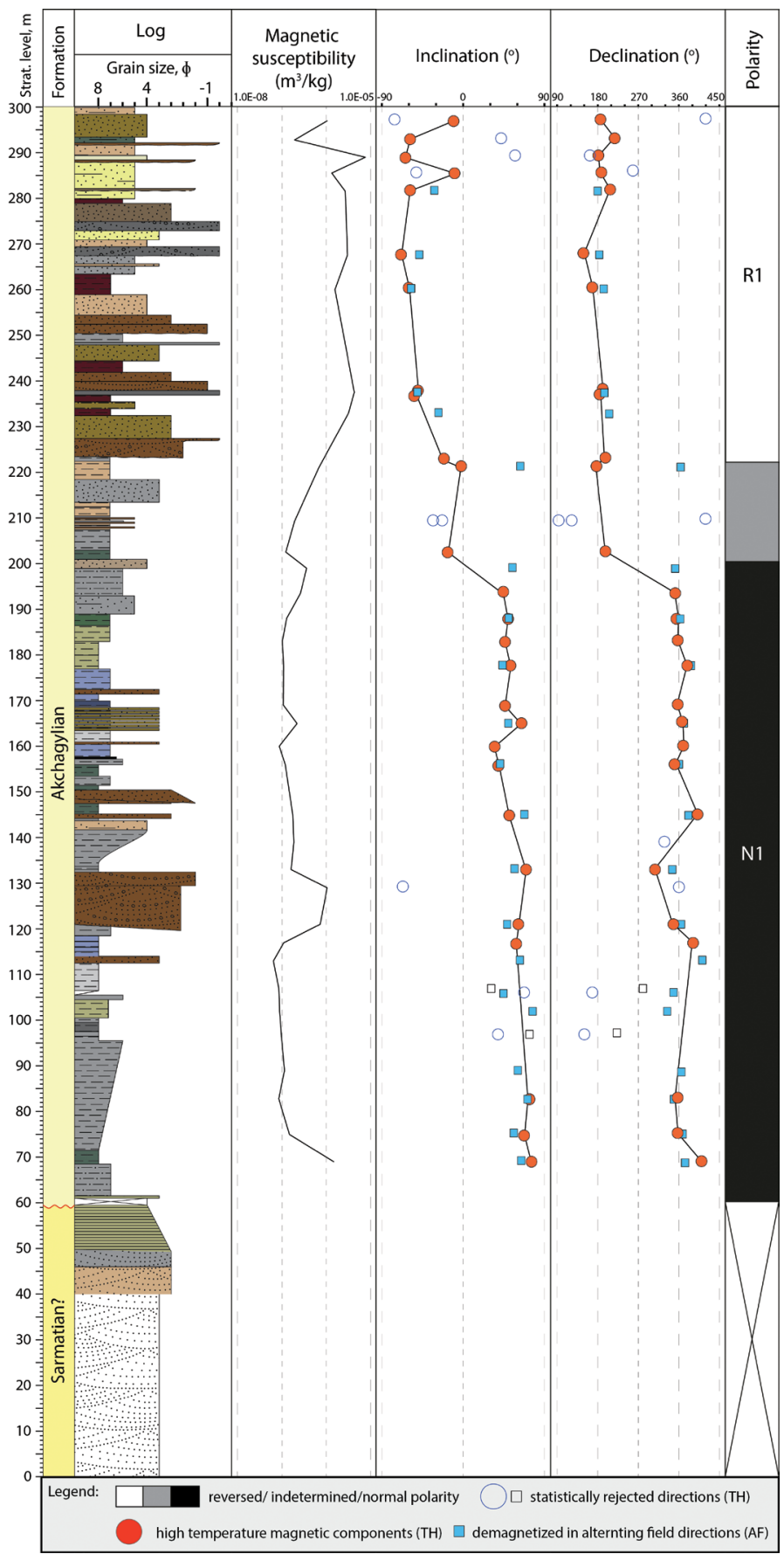

Figure 5.9 Sedimentary log and magnetostratigraphy of the Kushkuna section. Magnetic susceptibility is plotted on a logarithmic scale. 
The atmospheric ${ }^{40} \mathrm{Ar} /{ }^{36} \mathrm{Ar}$ inverse isochron intercept is $298.1 \pm 2.4$. Note that slightly different age interpretations are possible. Further, the relatively low radiogenic ${ }^{40} \mathrm{Ar}$ yields suggest some alteration, and thus, some minor Ar loss took place, potentially leading to an underestimation of the age.

The dated feldspar fraction has low K/Ca ration $(<0.1)$ and is, therefore, not a sanidine fraction, rather plagioclase. Due to the low amount of $\mathrm{K}$, measured intensities are low, and reliable analyses would require $>25$ grains per fusion. The current ages already range from 66 to $2 \mathrm{Ma}$, and large multi-grain experiments will be compromised by these older components. We, therefore, did not attempt any further analyses. The weighted mean age of the five youngest grains is $2.55 \pm 0.16 \mathrm{Ma}$, but the error is large.

For HG-4, we analysed the sanidine fraction. In tray $19 \mathrm{~T} 13$ we fused 5 grains/hole and in tray $19 \mathrm{~T} 1415$ grains/hole. Radiogenic ${ }^{40} \mathrm{Ar}$ yields for the sanidine range from 75 to $95 \%$. If we select the weighted mean age, including the highest number of analyses with overlapping ages and MSWD < t-test statistic at $95 \%$ confidence level, the weighted mean age arrives at $2.66 \pm$ $0.05 \mathrm{Ma}$. The atmospheric ${ }^{40} \mathrm{Ar} /{ }^{36} \mathrm{Ar}$ inverse isochron intercept is $295.4 \pm 4.5$.

For HG-1033, we analysed the sanidine fraction. In tray 19T13, we fused 5 grains/hole and in tray $19 \mathrm{~T} 1410$ grains/hole. In both trays, we observe a large spread of ages ranging from 1.8 to $27 \mathrm{Ma}$. We conclude that this ash contains many reworked components, and reliable age information cannot be obtained from the full spectrum of data. We note, however, that the two youngest fusions yield a weighted mean age of $1.88 \pm 0.03 \mathrm{Ma}$.

\subsection{Discussion}

\subsubsection{Correlation to the GPTS ("short" Akchagylian vs. "long” Akchagylian)}

Our new ${ }^{40} \mathrm{Ar} /{ }^{39} \mathrm{Ar}$ ages from the Hajigabul section confirm the previous magnetostratigraphic correlation to the GPTS by Lazarev et al. (2019). Ash layer HG-4, which is located at the Productive Series-Akchagylian transition, has a ${ }^{40} \mathrm{Ar} /{ }^{39} \mathrm{Ar}$ age of $2.66 \pm 0.05$ Ma (Fig. 5.10). It indicates that the normal to reversed polarity transition at the base of the Akchagylian stage correlates indeed to the Gauss-Matuyama (C2An.1n/C2r.2r) boundary of the GPTS (2.59 Ma; Hilgen et al., 2012). Ash layer HG-1033 at level $1012 \mathrm{~m}$ has an age of 1.88 $\pm 0.03 \mathrm{Ma}$. This level is positioned within a normal polarity interval that was correlated to the Olduvai chron (C2n; $1.95-1.77 \mathrm{Ma}$ ) by Lazarev et al. (2019). The new ${ }^{40} \mathrm{Ar} /{ }^{39} \mathrm{Ar}$ age additionally validates the correlation of the normal polarity interval straddling the AkchagylianApsheronian transition to Reunion subchron (C2r.1n: 2.14-2.12 Ma) (Fig. 5.10). These results firmly establish the duration of the Akchagylian stage in the Kura Basin as dated between 2.7 and 2.1 Ma, in agreement with the "short-Akchagylian" scenario (Krijgsman et al., 2019; Lazarev et al., 2019). Our magnetostratigraphic resampling of the Kvabebi section did not confirm the presence of a short reversed polarity interval at the stratigraphic succession (140- 
$160 \mathrm{~m}$ in Fig. 5.6) that comprises the mammalian fossil site (Agustí et al., 2009). We did observe several weakly magnetised samples there that may probably explain a different (reversed polarity) interpretation. However, placing strict criteria to the demagnetization results leads us to conclude that the Kvabebi magnetostratigraphy comprises a single normal polarity interval from the base of the section until the transition to reversed polarities at level $210 \mathrm{~m}$ (Fig. 5.11). This is in good agreement with the magnetostratigraphic results of the Kushkuna section that also reveals a long $(\sim 150 \mathrm{~m})$ normal polarity interval at the lower part of the section. The new ${ }^{40} \mathrm{Ar} /{ }^{39} \mathrm{Ar}$ ages for the Akchagylian deposits at Kvabebi are less straightforward and show widely

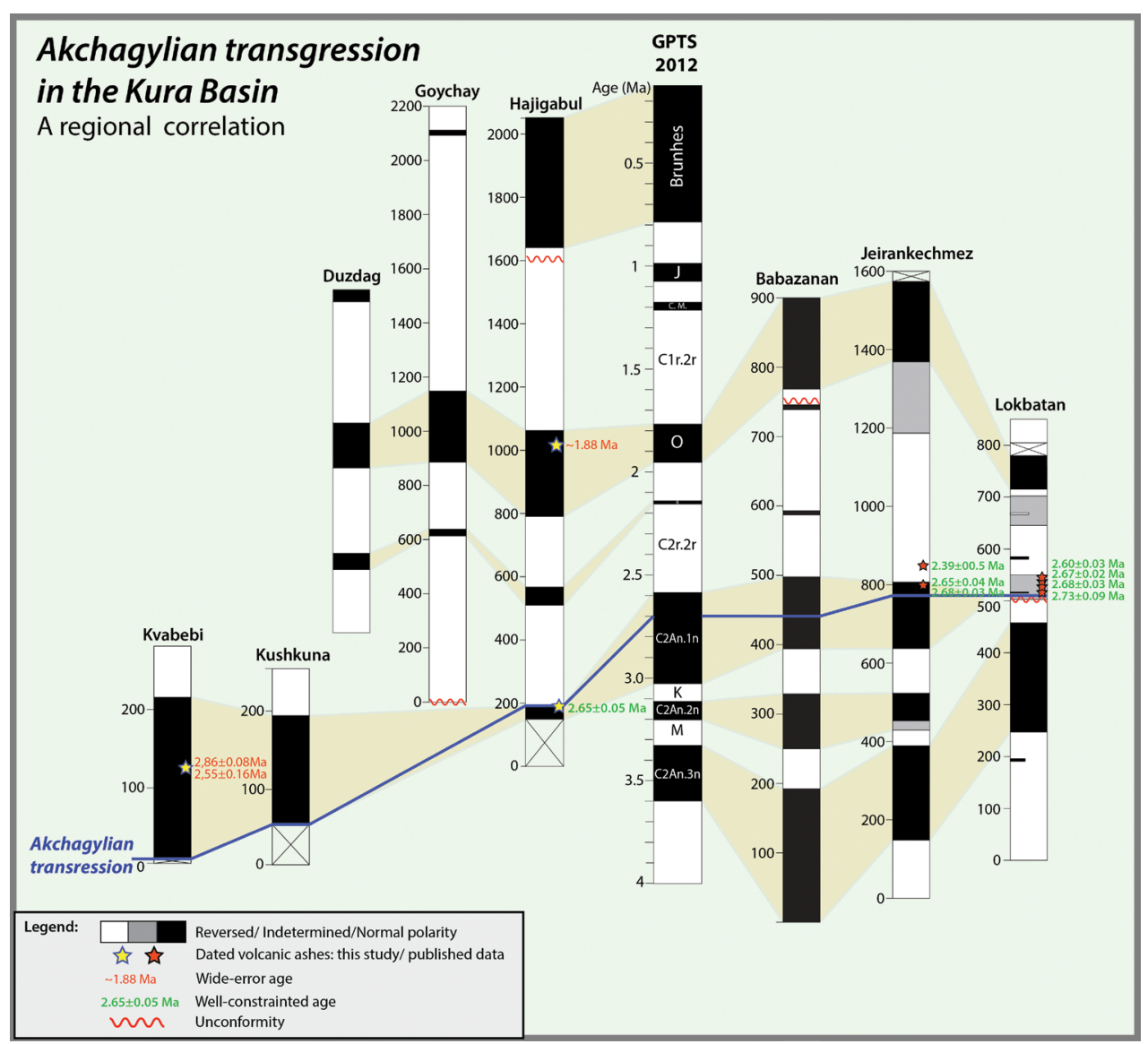

Figure 5.10. Magnetostratigraphic correlation for the studied and revised sections across the Kura Basin supported by ${ }^{40} \mathrm{Ar} /{ }^{39} \mathrm{Ar}$ ages and position of the Akchagylian flooding in the Geomagnetic Polarity Time Scale (GPTS). Used GPTS after Hilgen et al. (2012). Magnetostratigraphy of: Kvabebi and Kushkuna (this study), Duzdag (Pevzner, 1986), Goychay and Hajigabul (Lazarev et al., 2019), Babazanan and Lokbatan (van Baak, 2015a), Jeirankechmez (van Baak et al., 2019). ${ }^{40} \mathrm{Ar} /{ }^{39} \mathrm{Ar}$ ages: Kvabebi and Hajigabul (this study), Jeirankechmez and Lokbatan (Hoyle et al., 2019b; van Baak et al., 2019). 
varying ages ranging from 2.86 to $2.55 \mathrm{Ma}$ (Fig. 5.10). Nevertheless, all these results indicate that the base of the section is younger than the Kaena (C2An.1r; 3.12-3.03 Ma) subchron (Hilgen et al., 2012). We thus conclude that the normal polarity intervals in both Kvabebi and Kushkuna correlate to the upper Gauss chron C2An.1n (Hilgen et al., 2012).

The Akchagylian fauna in the westernmost Kura Basin is not necessarily in disagreement with the proposed flooding scenario at $2.7 \mathrm{Ma}$ for the eastern part of the Kura Basin (Richards et al., 2018b; Hoyle et al., 2019b; van Baak et al., 2019). The new data are also in good agreement with the U-Pb detrital zircon ages from the Sarica section in the central Kura Basin that constrain the maximum depositional age for the underlying Productive Series strata at $2.5 \pm 0.2 \mathrm{Ma}$ (Forte et al., 2015). In summary, most age constraints from both the Kura Basin (southwest Caspian) and the Turkmenistan region (southeast Caspian) indicate that the base of the Akchagylian is correlated to the upper Gauss chron C2An.1n and that the Akchagylian transgression occurred roughly synchronous throughout the entire South Caspian Basin at an age of $\sim 2.7 \mathrm{Ma}$ (Fig. 5.10).

\subsubsection{Akchagylian successions across the Kura Basin}

The new geochronological age constraints from Kvabebi and Kushkuna sections, together with the previously dated sections, can be used to create a W-E transect across the entire Kura Basin to determine the temporal and spatial evolution of the basin during Akchagylian times. Besides Kvabebi and Kushkuna sections, the regional correlation scheme (Fig. 5.10) includes the following magnetostratigraphically dated sections: Duzdag (Ali-Zade et al., 1972; Pevzner, 1986), Goychay and Hajigabul (Lazarev et al., 2019), Babazanan, Jeriankechmez, and Lokbatan (van Baak, 2015a; Hoyle et al., 2019b; van Baak et al., 2019).

The Akchagylian flooding of the Caspian Basin initiated the development of a new depositional system in the Kura Basin. The western margin recorded an abrupt transgression towards the Akchagylian nearshore and floodplain deposits of Kvabebi/Kushkuna. The exact age of the basal Akchagylian remains uncertain because of the lack of absolute age dating, although the magnetostratigraphic data combined with the ${ }^{40} \mathrm{Ar} /{ }^{39} \mathrm{Ar}$ results indicate an age close to 2.7 Ma. After the flooding, a mud-dominated coast developed, disrupted by sparse fluvial sandstone bodies. The predominance of lagoon and floodplain depositional environments throughout most of the Kvabebi and Kushkuna sections implies that the position of the coastline remained constant for a sustained amount of time (Jorissen, 2020). The balance between basin subsidence and sediment supply kept the coastline in a relatively fixed position. The basal part of the Akchagylian is not exposed in the Goychay and Duzdag sections of central Azerbaijan, but a major lithological change is also observed in the eastern sections at Lokbatan, Jeirankechmez, Babazanan, and Hajigabul. There, the fluvio-deltaic sandstones and siltstones of the Productive Series are overlain with a sharp contact by littoral and offshore marlstones and claystones of the Akchagylian (Hoyle et al., 2019b; Lazarev et al., 2019). These fine-grained sediments serve 


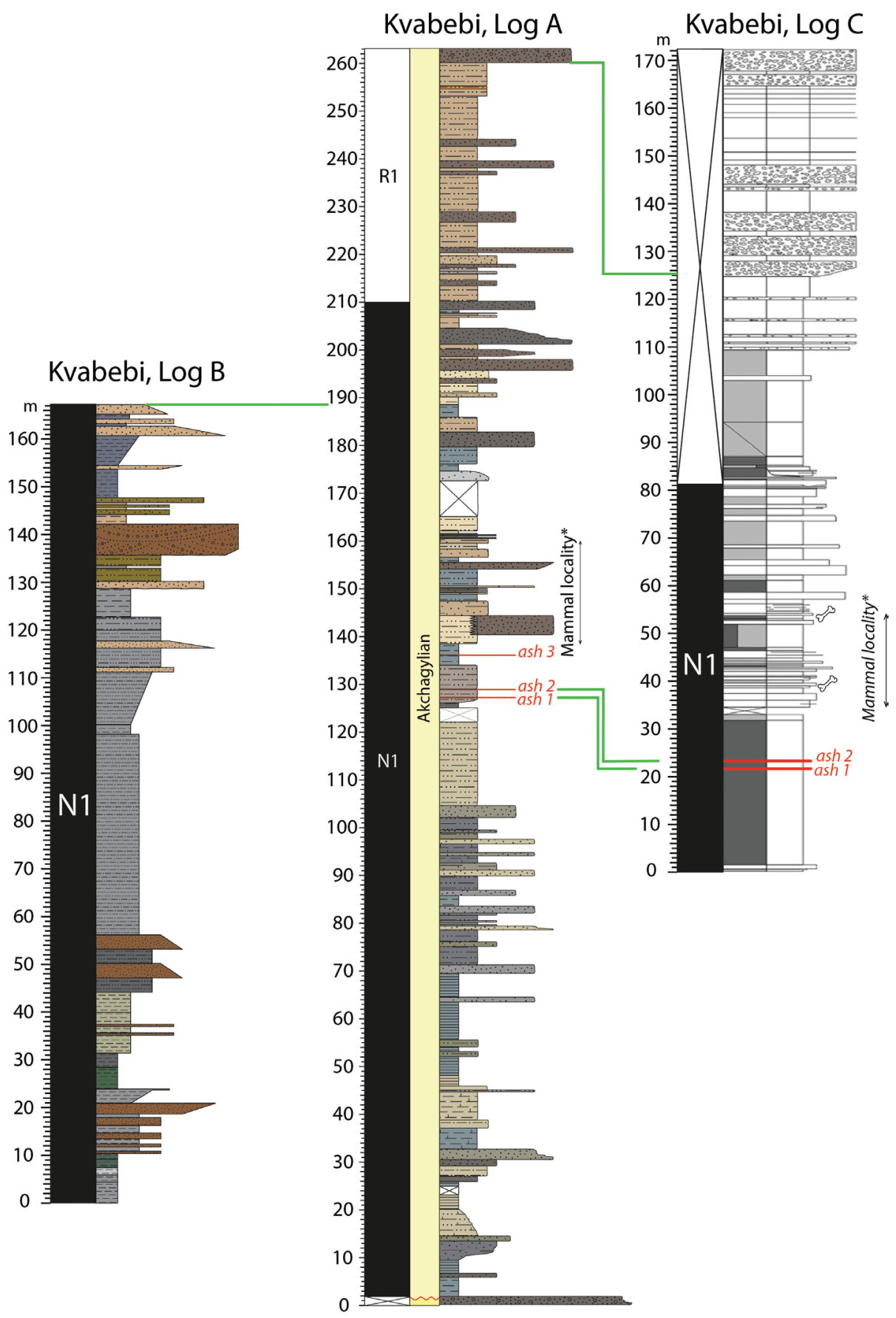

Figure 5.11 Lithological correlation "walked out" in the field between the $\log A, \log B$ and $\log C$. $\log$ is modified after Agustí et al., 2009. 
as an excellent cap rock for the hydrocarbon reservoirs of the underlying Productive Series (Aliyeva, 2005; Abdullayev et al., 2012). The occurrence of new faunal assemblages also marks the Akchagylian flooding. In Hajigabul, Lokbatan, and Jeirankechmez, the scarce freshwater microfauna of the Productive Series was replaced by Akchagylian oligo-, mesohaline ostracods, foraminifera, and molluscs (Richards et al., 2018b; Lazarev et al., 2019; van Baak et al., 2019) and meso- to polyhaline dinoflagellates (Hoyle, 2019a). The dinoflagellate assemblages also contain abundant "marine" species like Operculodinium centrocarpum that indicate a rise of salinity up to $\sim 35 \mathrm{psu}$ (Hoyle, 2019a). The elevated Sr isotopic ratios indicate the existence of an intrabasinal connection between the Caspian Sea and the Arctic Ocean (Bista, 2019; Van Baak et al., 2019), although the exact pathway remains enigmatic (Mordukhai-Boltovskoi, 1964; van Baak, 2015a; Richards et al., 2018b; Lazarev et al., 2019; van Baak et al., 2019).

In Kushkuna and Kvabebi, the last brackish water Akchagylian molluscs disappear slightly below the Gauss-Matuyama polarity ( 2.6 Ma), when continental and fluvial coarse-grained facies prograde (Jorissen, 2020). This change is also observed in the Vashlovani section and probably reflects the increase of sediment supply caused by the growth of the Greater Caucasus (Forte et al., 2015). The tectonic nature of the sediment accumulation patterns in the westernmost Kura Basin is also revealed by the relatively high sediment accumulation rates in the Akchagylian of Kushkuna and Kvabebi (Fig. 5.10). Assuming the Akchagylian starts at 2.7 $\mathrm{Ma}$, this results in average accumulation rates of $1.73 \mathrm{~m} / \mathrm{kyr}$ and $1.33 \mathrm{~m} / \mathrm{kyr}$ for the Kvabebi and Kushkuna sections, respectively. For the same time interval (C2An.1n), sediment accumulation rates in Babazanan and Jeirankechmez are $0.23 \mathrm{~m} / \mathrm{kyr}$ and $0.37 \mathrm{~m} / \mathrm{kyr}$, respectively. This suggests that the westernmost part of the Kura Basin experienced much stronger subsidence during the Akchagylian than the eastern parts.

Between 2.5-2.4 Ma, a remarkable palaeoenvironmental change is characterised by transition from mesohaline to oligohaline environments in both the central and eastern parts of the Kura Basin. In the Duzdag section, this event is expressed by the disappearance of all faunal elements in a so-called "desalinated" interval below the Apsheronian (Ali-Zade et al., 1972). In Goychay, it is marked by a sharp disappearance of foraminifera (Lazarev et al., 2019). In the eastern Kura section Lokbatan the marine faunal elements like Operculodinium centrocarpum disappear (Hoyle, 2019a). This faunal reorganisation reflects a general salinity decrease in the Caspian Basin that may be linked to the termination of the Caspian - Arctic connection.

After 2.4 Ma the faunal record of the Kura basin is highly impoverished and mainly represented by several oligohaline ostracod species. At $2.13 \mathrm{Ma}$ (correlated to Reunion subchron), the first indicative Apsheronian molluscs Monodacna sp. and Apscheronia propinqua appear that mark the Akchagylian-Apsheronian boundary (Lazarev et al., 2019). The following salinity increase and enrichment of Apsheronian fauna points at the establishment of a two-way connection between the Black and Caspian Sea Basins. 


\subsubsection{Implication of new age constraints for other interdisciplinary studies}

The new geochronologic constraints restrict the Akchagylian to the time interval between 2.7 and 2.1 Ma. This is significantly shorter than the previous age estimates of 3.6-1.8 Ma that figure in the regional geological time scales. This appeals to a revision of numerous archaeological, faunal, and palaeoenvironmental reconstructions in the Caspian region, where Akchagylian deposits were used as a time benchmark.

The palaeoclimate data derived from a palynological study of the Terek Basin (North Caspian Basin) shows significant warming characterised by the expansion of the broadleaved mixed oak forests (Naidina and Richards, 2016). This event has been attributed to the lower Akchagylian and was initially correlated to the Mid-Pliocene Warm Period dated at 3.2 Ma using the "long" Akchagylian time frame. Here we proclaim that this warm interval is significantly younger, and its geochronological position is yet to be revised.

The new age constraints from Kvabebi and Kushkuna also clarify the regional stratigraphic position of the mammalian faunas discovered in SW Caspian region (Ali-Zade et al., 1972; Lebedeva, 1972; Vekua, 1972). The large mammalian fossil remains from the Kura margin are attributed to biozone MN16b ( 2.8-2.5 Ma) (Bukhsianidze and Koiava, 2018; Krijgsman et al., 2019). These views, however, were in contradiction with the previous age model for Kvabebi site, that dated the mammal locality at 3.1 Ma (Agustí et al., 2009). The MN16b zone is, however, in good agreement with our new chronology for the western Kura Basin, which may further help to improve the biogeographic history of the region. The Kvabebi site comprises large mammalian fauna represented by African and Eurasian lineages (Agustí et al., 2009). It has been interpreted that the Kvabebi large mammals had strong affinities with the late Miocene forms recorded from the Subparatethyan or Greek-Iranian province of the Mediterranean region. This allowed hypothesizing that the Southern Caucasus acted as a refuge area to the late Miocene Eurasian large mammalian forms (Bukhsianidze and Koiava, 2018).

One of the most enigmatic archaeological sites in the Caspian region is Rubas-1, located in Dagestan (Russia). This site contains one of the oldest stone tools found in Eurasia; retrieved from Rubas-1, layer 5 (Anoykin and Rybalko, 2013). The tool layer is followed by an $8 \mathrm{~m}$-thick clay package (layer 4) that has (sporadic) Akchagylian microfauna. A magnetostratigraphic study of this succession dated the stone tools at 2.2-2.3 Ma (Derevianko et al., 2015). Our new age constraints on the Akchagylian indicate that the Rubas-1 site must be older than 2.13 Ma. We suggest that the previous magnetostratigraphic correlation to the Olduvai chron must be revised to the older Réunion chron. The age of the site may become better constrained with the additional use of high-resolution palynological analysis that in the regions showed its high efficiency in high-resolution correlations to the global climate records (Hoyle et al., 2019b). 


\subsection{Conclusion}

Kvabebi and Kushkuna are two westernmost marginal sections of the Kura Basin (South Caspian region) that contain remains of both Akchagylian invertebrate fauna and large terrestrial mammals. In both sections, the Akchagylian claystones overlie late Miocene sandstones and conglomerates with an erosional contact. Our new magnetostratigraphic results show that the Akchagylian deposits start within a long (150-200 m) normal polarity zone that changes to a reversed polarity zone in the upper part of the sections. This polarity change is correlated to the Gauss-Matuyama polarity reversal that has an age of $2.581 \mathrm{Ma}$. The ${ }^{40} \mathrm{Ar} /{ }^{39} \mathrm{Ar}$ dating of sanidine and biotite from the ash layer 2 in Kvabebi resulted in two different ages of $\sim 2.55 \mathrm{Ma}$ and $\sim 2.86 \mathrm{Ma}$ respectively. Despite the age uncertainty, these dates support the correlation of the normal polarity zones in both sections to the upper Gauss correlation.

The new magnetostratigraphic age constraints from Kushkuna and Kvabebi allowed creating a W-E transect of eight Akchagylian sections across the entire Kura Basin. In these sections, we show, that the Akchagylian flooding occurs in the upper Gauss subchron C2An.1n. This correlation has been supported by several existing ${ }^{40} \mathrm{Ar} /{ }^{39} \mathrm{Ar}$ dates of volcanic ashes from the east Kura Basin (Jeirankechmez and Lokbatan) that suggest the age of the Akchagylian flooding is $\sim 2.7 \mathrm{Ma}$ (Hoyle et al., 2019b)

The new ${ }^{40} \mathrm{Ar} /{ }^{39} \mathrm{Ar}$ dating of two volcanic ashes from the Gauss-Matuyama transition and the Olduvai subchron of the Hajigabul section resulted in ages of $\sim 2.65$ and $\sim 1.88$ Ma respectively, confirming the previously published magnetostratigraphic correlation of the section (Lazarev et al., 2019). These ages also validated the Akchagylian-Apsheronian boundary in the Hajigabul section, marked by the occurrence of Apsheronian indicative molluscs Monodacna sp. and Apscheronia propinqua, in the middle of the Reunion subchron (2.13 Ma).

The new and revised geochronological, geochemical, and palaeoenvironmental data from eight sections across the Kura Basin show that two distinct intervals can be distinguished within the Akchagylian stage. The first interval ( 2.7-2.5 (2.4) Ma) is characterised by the presence of rich mesohaline and polyhaline (marine) faunal elements like foraminifera, dinoflagellates, molluscs etc. that occur in the basin along with the Ackhagylian flooding. The elevated $\mathrm{Sr}$ isotopic ratio accompanied by marine faunas were considered as a result of interbasinal connection between the Caspian Sea and the Arctic Ocean (Mordukhai-Boltovskoi, 1964; Richards et al., 2018b; Hoyle et al., 2019b; van Baak et al., 2019). The second interval (2.5 (2.4)$2.1 \mathrm{Ma}$ ) begins with the disappearance of marine faunas followed by the presence of scarce oligohaline microfauna. This abrupt change is considered as a termination of the Caspian Arctic connection that stopped delivery of marine waters in the Caspian Basin.

The Caspian and Caucasian regions being at the crossroad between Europe, Asia and Africa comprise numerous important palaeontological and archaeological sites that define the biogeographic and anthropologic histories of Eurasia. The age constraints of many of these localities rely on the old Akchagylian age constraints that were proposed in the 70th of the last 
century. Our new integrated age constraints show that the age of those localities, as well as the stratigraphy in the other parts of the Caspian region now, should be revised.

\subsection{Acknowledgements}

We would like to thank Qucho and Maia Navrozashvili for an amazing Georgian hospitality during our filedwork. This research as a part of the PRIDE project (Pontocaspian RIse and DEmise) was funded by the European Union's Horizon 2020 research and innovation program, under the Marie Sklodowska-Curie (grant agreement № 642973). 
AKCHAGYLIAN FLOODING IN THE WESTERNMOST KURA BASIN 
(1)

1)

4

-
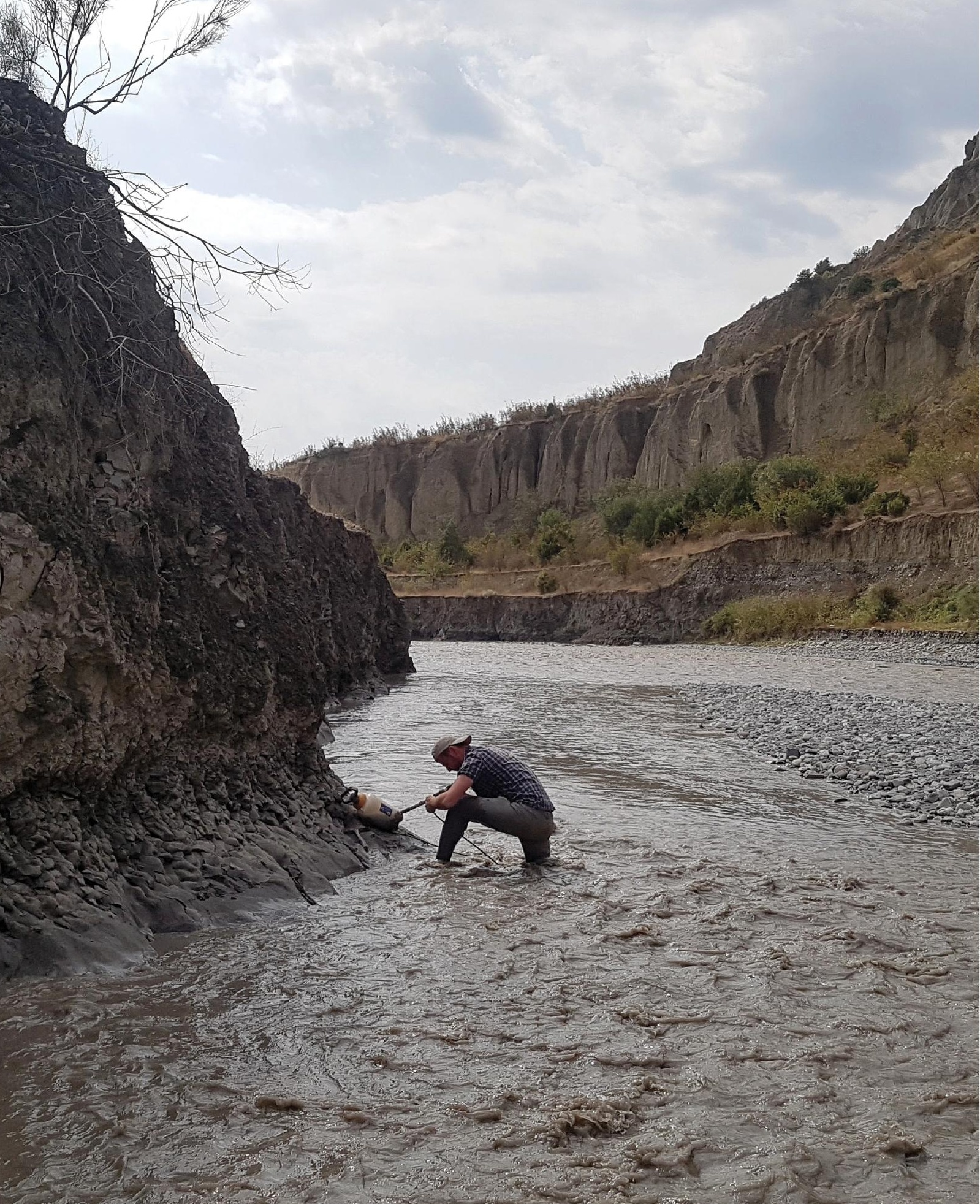

A daily routine of paleomagnetist in a field. Paleomagnetic sampling of Akchagylian deposits of the Goychay section in a muddy Goy river. October 2017. 


\section{6}

\section{EPILOGUe}

This thesis provides new insight into the palaeoenvironmental history and regional stratigraphy of the Eastern Paratethys during the late Miocene - Middle Pleistocene. During this time amplification of convergence between Eurasian, African and Arabian plates superimposed on enhanced climatic oscillations accelerated the isolation and shrinking of this anomalohaline water mass. These processes, expressed in dramatic high-amplitude base-level variations, resulted in episodes of hydrological isolation and connection between the Paratethyan affinities. Subsequent changes in water chemistry and salinity provoked numerous reorganisations in the regional aquatic ecosystems by making them escape, adopt or extinct under new conditions.

This work studied the west-east migration of Paratethyan fauna through time and focused on the palaeoenvironmental context of the major regional biological turnovers in the Paratethyan affinities during the late Miocene, Mio-Pliocene and Plio-Pleistocene keyintervals. In this final chapter, a summary of the main outcomes and future research directions and perspectives are discussed.

\section{Part 1 - Ending of the main endorheic phase in the Eastern Paratethys and first faunal immigrants (late Miocene)}

Chapter 1 provides significant refinement of the late Miocene stratigraphy of the Dacian Basin bringing it in line with the other Paratethyan basins. The Khersonian-Maeotian boundary has been dated at 7.63 Ma, which is in a good agreement with the 7.6 Ma age in the Black Sea (Rybkina et al., 2015) and 7.65 Ma in the other parts of the Dacian Basin (Palcu et al., 2019b). The Maeotian-Pontian boundary is now firmly established at 6.1 Ma that is synchronous with the records of the Black (Rostovtseva and Rybkina, 2017) and Caspian Seas (van Baak et al., 2016).

Besides magnetostratigraphic age constraints, Chapter 1 shows how important it is to study the biotic record inextricably with the analysis of depositional environments. In the previous decades, many discussions were going on salinity changes in the lower Maeotian of the Dacian Basin (Iljina et al., 1976; Kojumdgieva et al., 1989; Paramonova, 1994). There, the lower Maeotian biotic record contains remarkable intervals with freshwater mollusc fauna, followed by brackish water one. In contrast, in the Black Sea, the record immediately begins with highly brackish molluscs (i.e. Dossinia meotica zone). Such differences in salinity resulted 
in assumption of a delayed transgression in the Dacian Basin and left position of freshwater beds unassigned (i.e. Mactra-Ervilia zone, Kojumdgieva et al., 1989).

We show that a better understanding of the sequence stratigraphy of the basin reveals that the Maeotian transgression in the Dacian Basin was roughly synchronous with the onset of the Maeotian in the Black Sea domain; both being characterized by an abrupt rise of the base level and an influx of mesohaline microfauna ('Ammonian becarii' acme zone). When the flooding reached its maximum, the system switched from transgressive system tract (TST) to highstand system tract (HST), and the coastline moved basinward. The post-flooding lower Maeotian deposits interpreted as back-barrier lagoons indeed contain freshwater water molluscs with Viviparus moldavicus and Sinzowinaia subhoernesi. At the same time, the claystone interbeds deposited in distal offshore environments comprise brackish water ostracod fauna. We thus conclude that the Dacian Basin in the lower Maeotian was brackish water (oligohaline-low mesohaline, 3-7\%o) with a strong freshening of the basin margins. It is important to notice that the separate use of the mollusc and microfauna proxies could lead to principally different interpretations of the palaeoenvironments, making it freshwater (based on molluscs) or brackish water (based on microfauna). Semi-isolated systems like the Eastern Paratethys thus have a more complex salinity profile than previously anticipated, and proper knowledge of depositional environments is hereby crucial for understanding the fauna distributions.

Another remarkable transgression event took place at 6.3 Ma, which we documented for the first time in the region. The abrupt, two-fold increase of sediment accumulation rates, inferred from the magnetostratigraphy, suggests that this rise of base level may be related to the increase of subsidence in the adjacent Focşani depocentre, similar to the observations on the neighbouring Putna and Râmnicu Sărat sections (Vasiliev et al., 2004). This event may be relevant for tectonic studies of the region, especially those dealing with the interpretation of seismic profiles.

\section{Part 2 - The hidden Paratethyan affinity: Age constraints, depositional environments and faunal record of the Neogene Denizli Basin (SW, Anatolia, Mio-Pliocene)}

The second part of the thesis represents the very first integrated magneto-biostratigraphic study in the Denizli region. The most important question on the age of Pontocaspian fauna discovered in the basin was basically resolved. We concluded that the Pontocaspian assemblage with its key representative Didacna occurred in the basin at $~ 5.6-5.4 \mathrm{Ma}$, in the event that is potentially related to the Lago Mare phase of the Mediterranean. Nevertheless, the studied assemblage does not contain typical Lago Mare taxa like molluscs Pontalmyra (Taviani et al., 2007) that can be linked to either strong ecological filter on the way to Denizli or to a more complex migration mechanism including avian dispersal or through a direct connection with the Black Sea avoiding the Aegean Basin. 
The remaining question in Denizli is "what are the ecology and origin of the genus Didacna?". This mollusc became abundant in the Middle Pleistocene of the Caspian Sea, where it serves as a key biostratigraphic tool (Yanina, 2013). The genus is considered to occur only in the Early Pleistocene (Apsheronian time, 2.1-0.85 Ma) in the southwestern part of the Black Sea from a common ancestor of unknown origin (Nevesskaja, 2007). Now, we provide the oldest record of this genus showing its presence in the latest Miocene.

The origin of Didacna and its occurrence in the Denizli Basin remains enigmatic. Future studies should focus on the biogeography of the region, building an ecological and taxonomic database for the fossil molluscs and on the reconstruction of the faunal dispersal history.

\section{Part 3 - Magneto-biostratigraphy, palaeoenvironments and faunal turnovers in the Kura Basin during the latest Pliocene-Middle Pleistocene}

The third part of the thesis has a large impact on the late Pliocene-Early Pleistocene stratigraphy of the Caspian region. Our study proposes significant changes in the age and duration of regional stages. Along with other recent studies, we propose to place the base of the Akchagylian Stage at $2.7 \mathrm{Ma}$ (in the current regional scheme is at $3.6 \mathrm{Ma}$ ), the Akchagylian-Apsheronian boundary at $2.13 \mathrm{Ma}$ (against $1.8 \mathrm{Ma}$ in the current scheme) and the Apsheronian-Bakunian at $0.85 \mathrm{Ma}$ (against 0.78 $\mathrm{Ma}$ in the current scheme). These results derive from a high-resolution magneto-biostratigraphic and ${ }^{40} \mathrm{Ar} /{ }^{39} \mathrm{Ar}$ isotope dating presented in chapters 4 and 5. The updated ages appeal to a reassessment of the age constraints and palaeoenvironmental reconstruction in the other parts of the Caspian Basin - the North Caspian region and especially in the Akchagylian stratotype area on the Turkmenian side of the South Caspian Basin. This problem, however, may take some time as the North Caspian records are quite limited in length and exposure while the Turkmenian sections are not accessible due to political reasons.

Integration of dating, sedimentology and palaeontology shows that changes occurring in faunal assemblages are often linked to local changes in depositional environments rather than to regional trends. The Kvabebi and Kushkuna sections (Chapter 6) are good examples. In previous studies on these sections, the Akchagylian deposits were subdivided into three packages often referred to substages - lower, middle and upper (Ali-Zade, 1961; Ali-Zade et al., 1972; Lebedeva, 1972). This subdivision was based on the faunal trend observed in the Akchagylian deposits throughout the Caspian Basin: sparse mollusc assemblages in the lower Akchagylian (3.6-2.7 Ma), rich in the middle ( 2.7-1.9 Ma) and again impoverished in the upper $(\sim 1.9-$ $1.8 \mathrm{Ma}$ ). The application of this scheme in Kushkuna and Kvabebi automatically placed these sections between 3.6 and 1.8 Ma. Our age constraints combined with the sedimentological study of E. Jorissen (2020) showed that the sections cover only the $\sim 2.7-2.55 \mathrm{Ma}$ interval, while fauna followed the changes in depositional environments - lagoon-floodplain brackish water settings in the lower and middle parts and fluvio-terrestrial in the upper part of the section. 
This demonstrates again that in complex systems like the semi-isolated Pontocaspian basins, one proxy cannot be fully representative for the reconstruction of palaeoenvironments and an integrated approach must be applied.

The analysis of biotic and ${ }^{87} \mathrm{Sr} /{ }^{86} \mathrm{Sr}$ records along the Goychay and Hajigabul section, all performed in the frame of the PRIDE project, revealed that the Caspian Sea experienced episodic connections with the Black Sea in the Early Pleistocene, starting from 2.1 Ma (Bista, 2019; Lazarev et al., 2019; Jorissen, 2020). According to previous views, however, these connections were only enabled in the Bakunian (Middle Pleistocene). We showed that the first major connection was already established at 2.1-2.0 Ma, as indicated by the biotic record of the Hajigabul section. Further, small-scale connections are yet to be studied in higher resolution.

It has become clear that understanding the Pleistocene connectivity history between the Caspian and Black Sea basins requires interdisciplinary studies in the Black Sea area as well. There is still a high level of uncertainty about the duration and definition of the Black Sea PlioPleistocene regional stages (Krijgsman et al., 2019). This complicates the reconstruction of the regional biogeography and palaeoenvironments. Future studies on the complex hydrology and faunal evolution of the Plio-Pleistocene Black Sea region are thus very welcome. 
EPILOGUE 


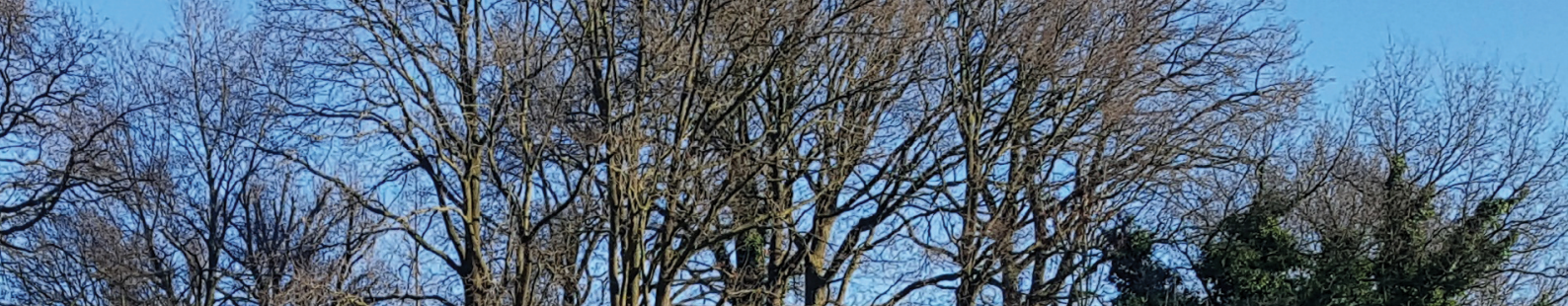

(1)

(1)

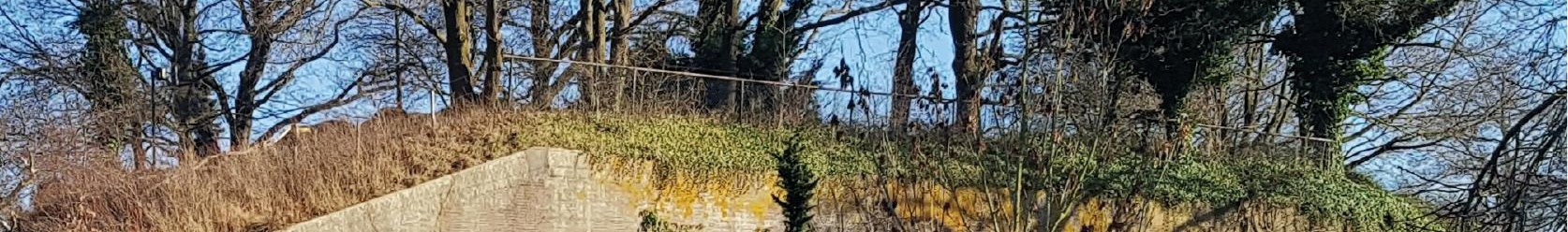

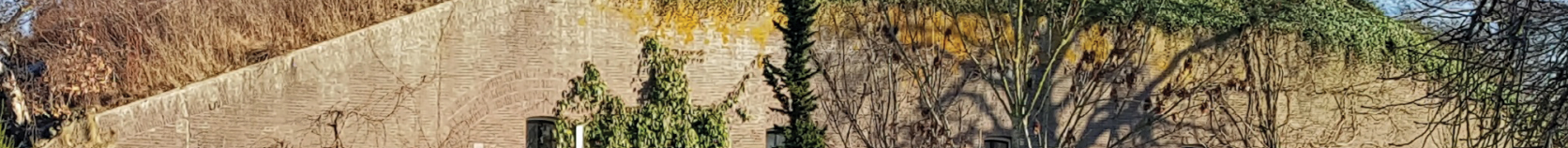

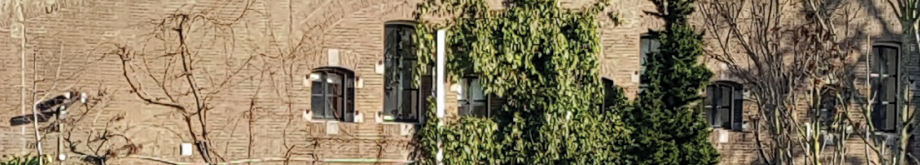

(5) (1)

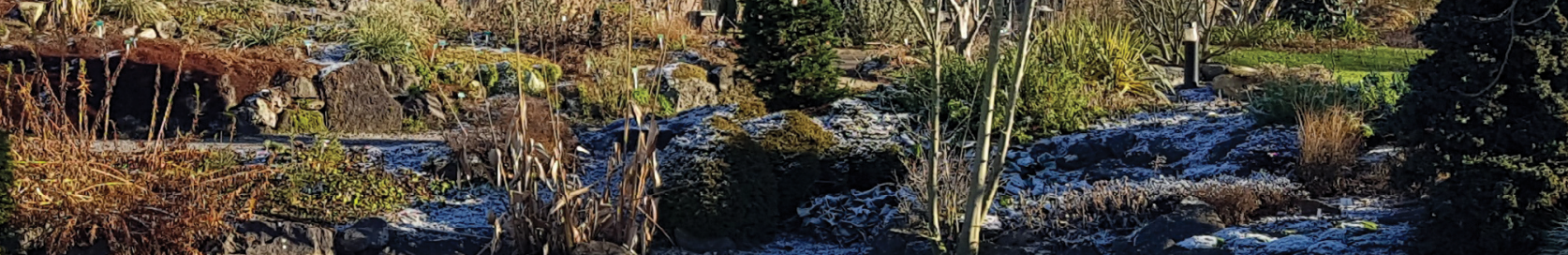
and
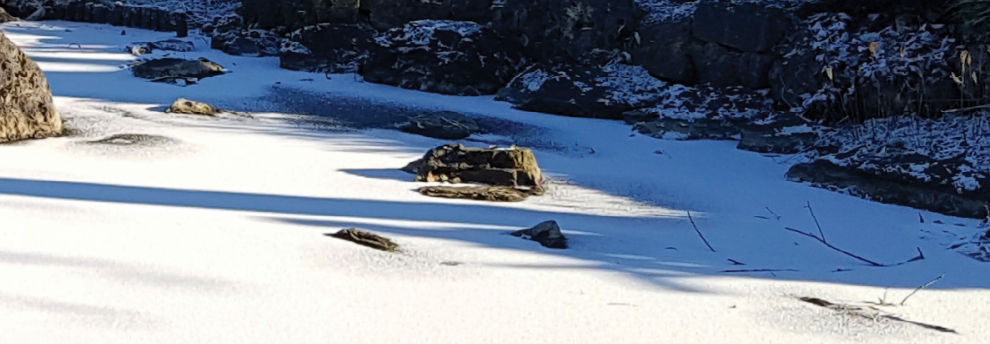

$>$
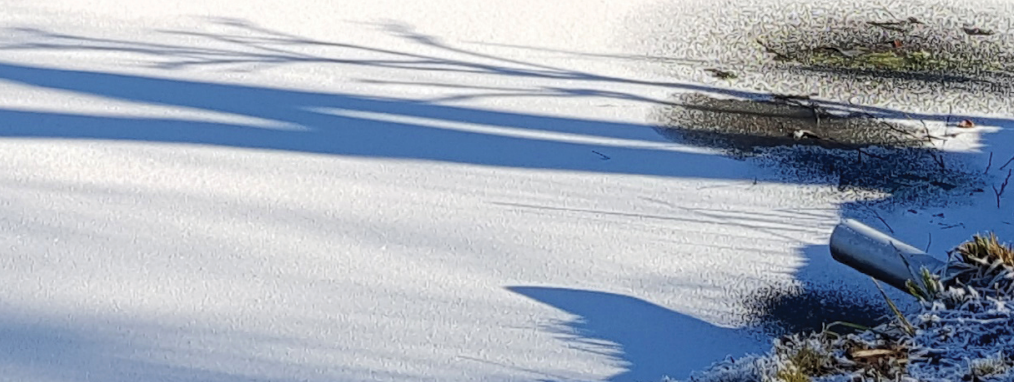


\section{ACKNOWLEDGEMENTS}

The last four years of my $\mathrm{PhD}$ were the years of Great learning. It is not only about science but also about friendship, open mindedness, tolerance, collaboration and simple ability to smile to other people (you know how unsmiling people from Russia are :)). All of these would not be possible without the help and support of my supervisors, colleagues, friends and family.

First of all, I would like to thank two great Dutch scientists - my supervisor Prof. Dr. Wout Krigsman and the director of the PRIDE project Dr. Frank Wesselingh for giving a chance to a 22-years old Russian student during the interview in Leiden back in 2015. It is now an abyss between me as a specialist and a human being in 2015 and now, in 2020 and I cannot imagine how would run my life If I was not selected for PRIDE. I am very thankful to my amazing co-supervisors Christiaan van Baak, Hemmo Abels and Arjan de Leeuw who trained me in the lab and the field, starting from simple drilling of pmag samples to how to distinguish delta front from shoreface. Special thanks to Arjan de Leeuw for being an unbelievable motivator and a mental supporter, at certain intervals of my training it was really helpful.

I would also like to thank the members of the dissertation committee: Anneleen Foubert, Rachel Flecker, Klaudia Kuiper, Nuretdin Kaymakci and Josep M. Parés. Thanks, Margot Stoete for helping me to design this book and the cover. The organisation of activities in PRIDE like network training events, conference, administrative work would simply stuck without an enormous task of Caroline van Impelen. I would also like to thank the mebers of the PRIDE scientific committee - Salomon Kroonenberg and Hedi Oberhänsli with whom I enjoyed exciting conversations.

Many thanks to my friends and fellow PRIDE ESRs: Anouk D’Hont, Aleksandre Gogaladze, Liesbeth Jorissen, Matteo Lattuada, Diksha Bista, Thomas Hoyle, Alberto Martínez-Gándarra, Sri Nandini, Lea Rausch, Sifan Koriche, Manuel Sala-Pérez, Arthur Sands, Sabrina van de Velde and Justine Vandendorpe. You all guys made these years unforgettable and I hope we will be meeting each other again and again. Mr Hoyle, thank you for our tea breaks during which you usually laughed at me for my milky tea while drinking your proper Builders Brew. Elisabeth Jorissen - the one sitting next to me in the office for four years as well as being a great companion in the field, thank you for bringing a lot of French charm and funny moments into my life ${ }^{\star}$. Sabrina van de Velde, my secret soul friend with whom I can be open, calm and thoughtful and share my feelings and thoughts. In opposite, Sri Nandini, thank you for being 
my crazy-laughing mate. Lea Rausch, I am so glad to know such an organised and fantastic person like you. You are a perfect example of self-confidence and professionalism and working with you in the field in Turkey and Romania was a great pleasure. Diksha Bista, you are a great supporter that comes to help when it was really needed, thank you for that.

During my PhD I got familiar with tens of wonderful researchers from around the world. Some of them became my co-authors with whom we produced many good papers and will write even more. I am very thankful to you for providing your data, field assistance, scientific support: Marius Stoica, Oleg Mandic, Iuliana Vasiliev, Cihat and Hülya Alçiçek, Thomas Neubauer, Franceska Sangiorgi, Tamara Yanina, Elmira Aliyeva, Oriol Oms, Maia Bukhsianidze, Davit Vasilyan, Max Bouwmeester, Klaudia Kuiper, Vusala Aghayeva, Sergey Popov, Guzel Danukalova and Andrey Zastrozhnov.

It was a big pleasure to work with present and former colleagues at the Paleomagnetic laboratory "Fort Hoofddijk" that created a special atmosphere of friendship and support: Mark Dekkers, Cor Langereis, Dan Palcu, Maxim Krasnoperov, Lennart de Groot, Nathan Marshall, Anne-Christine da Silva, Karin Sant, Annique van der Boon, Damien Pas, Bertwin de Groot, Arjen Grothe, Nick Kelder, Annemarieke Béguin, Frederico Andreetto and many more students and visitors who came and went while I was there. I would also like to thank colleagues from CASP (Cambridge, UK) that hosted me and Liesbeth during our secondment in OctoberNovember 2016.

Despite being very far from my home city Tomsk in Russia, I kept contact with my friends and colleagues that could share with me news about how is life at $-50^{\circ} \mathrm{C}$ and how many meters of so incredibly missing snow there is every winter. I am very thankful to my ex-supervisor and friend Prof. Sergey Leshchinskiy for giving me a great experience in geology and fieldwork organisation that consequently helped me during my PhD. Many thanks to my age-old friends from different parts of the world with whom I spent tremendous days of my life: Miroslava Stashiba, Hayk Hovakimyan, Veronika Rusakova, my best cousin Irena Raselli, Raeto Raselli, Jérémy Tissier and Océane Lapauze.

I grew up in enormously big family with four siblings: Eugenia, Elena, Alexander and Olga. I think, I will never be able to pay back to my truly heroic mother Irina, who raised five kids in the hard for Russia 90th, after my father tragically died in an auto-crash. Thanks to her we, unlike many other families in Russia of that time, were never hungry and always dressed.

And last but not least, I would like to thank Davit Vasilyan for being my heart friend and the best supporter, who in these years has divided every sadness of mine by two and doubled every happiness.

People, appearing in your life for even a little conversation, never come without purpose, there is always a lesson behind. 
ACKNOWLEDGEMENTS 


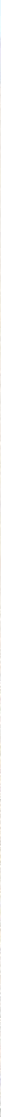

Haystacks in the field near the Pesochnodubrovka village, Tomsk region, Russia. Two days before a 


\section{AbOUT THE AUTHOR}

Sergei Lazarev completed a bachelor's degree in Geology (Palaeontology and Stratigraphy) with honour at the National Research Tomsk State University (2009-2013) and further continued his Master's study in Geology (Stratigraphy) at the NR TSU.

In 2014, Sergei received a scholarship of the French Government to attend a pioneer co-tutelle program between the National Research Tomsk State University, Russia and the University Lille 1, France. In 2015, Sergei successfully graduated and obtained a double Master degree in Geology.

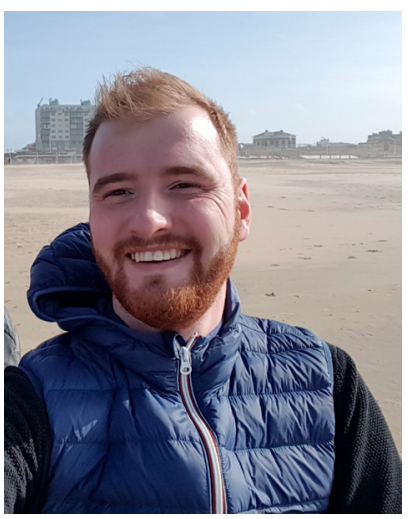

During his studies, Sergei participated in several paleontological expeditions on the Western Siberia's mammoth localities as well as worked as a field geologist in the International Geoarcheological Expedition in Uzbekistan.

In 2015 Sergei was selected as one of the Early Stage Researchers in the European Union's Horizon 2020 PRIDE (Pontocaspian RIse and DEmise) project. His position was based at the Department of Geoscience of the Utrecht University, the Netherlands. In this position, Sergei organised and/or assisted numerous fieldworks in Turkey, Azerbaijan, Romania, Armenia, Georgia, Russia and Kazakhstan where he was mainly responsible for paleomagnetic, stratigraphic and sedimentological studies. In 2016, Sergei was on a two-month secondment to CASP (Cambridge, UK) where he was trained in sedimentology.

Over the course of his $\mathrm{PhD}$, Sergei has been actively involved in teaching activities that include assistance in such disciplines as Magma and Minerals, Sedimentary Systems, Paleomagnetism and Natural Sciences.

At the final year of the PRIDE project, in 2018 Sergei was a member of the program committee for the PRIDE-RCMNS conference ("Ecosystem isolation and connection: rise and demise of biota in the Pontocaspian-Caucasian region") that was held in Tbilisi, Georgia. 


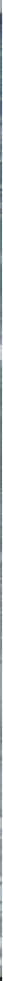

View on the Aegean Sea from the Gallipoli Peninsula, Turkey. January 2019. 


\section{PeER REVIEWED PUBLICATIONS}

Lazarev, S., Leeuw, A. de, Stoica, M., Mandic, O., van Baak, C.G.C., Vasiliev, I., Krijgsman, W., 2020. From Khersonian drying to Pontian flooding: late Miocene stratigraphy and palaeoenvironmental evolution of the Dacian Basin (Eastern Paratethys). Global and Planetary Change, in press. https://doi.org/10.1016/j.gloplacha.2020.103224

Rausch, L., Stoica, M., Lazarev, S., 2020. A late Miocene-early Pliocene Paratethyan type ostracod fauna from the Denizli Basin (SW Anatolia) and its palaeogeographic implications. Acta Palaeontologica Romaniae 16 (2), 3-56. doi: 10.35463/j.apr.2020.02.01.

Lazarev, S., Jorissen, E.L., van de Velde, S., Rausch, L., Stoica, M., Wesselingh, F.P., van Baak, C.G.C., Yanina, T.A., Aliyeva, E., Krijgsman, W., 2019. Magneto-biostratigraphic age constraints on the palaeoenvironmental evolution of the South Caspian basin during the Early-Middle Pleistocene (Kura basin, Azerbaijan). Quaternary Science Reviews 222, 105895. doi:10.1016/j. quascirev.2019.105895.

Jorissen, E., Abels, H., Wesselingh, F., Lazarev, S., Aghayeva, V., Krijgsman, W., 2019. Amplitude, frequency and drivers of Caspian Sea lake-level variations during the Early Pleistocene and their impact on a protected wave-dominated coastline. Sedimentology 67, 649676. doi:10.1111/sed.12658.

Sands, A.F., Sereda, S.V., Stelbrink, B., Neubauer, T.A., Lazarev, S., Wilke, T., Albrecht, C., 2019. Contributions of biogeographical functions to species accumulation may change over time in refugial regions. Journal of Biogeography 46(6), 1274-1286. doi:10.1111/jbi.13590.

Krijgsman, W., Tesakov, A., Yanina, T., Lazarev, S., Danukalova, G., van Baak, C.G.C., Agustí, J., Alçiçek, M.C., Aliyeva, E., Bista, D., Bruch, A., Büyükmeriç, Y., Bukhsianidze, M., Flecker, R., Frolov, P., Hoyle, T.M., Jorissen, E.L., Kirscher, U., Koriche, S.A., Kroonenberg, S.B., Lordkipanidze, D., Oms, O., Rausch, L., Singarayer, J., Stoica, M., van de Velde, S., Titov, V.V., Wesselingh, F.P., 2019. Quaternary time scales for the Pontocaspian domain: Interbasinal connectivity and faunal evolution. Earth-Science Reviews 188, 1-40. doi:10.1016/j. earscirev.2018.10.013. 
Krajcarz, M.T., Kot, M., Pavlenok, K., Fedorowicz, S., Krajcarz, M., Lazarev, S.Y., Mroczek, P., Radzhabov, A., Shnaider, S., Szymanek, M., Szymczak, K., 2016. Middle Paleolithic sites of Katta Sai in western Tian Shan piedmont, Central Asiatic loess zone: Geoarchaeological investigation of the site formation and the integrity of the lithic assemblages. Quaternary International 399, 136-150. doi:10.1016/j.quaint.2015.07.051.

\section{Peer reviewed publications to be submitted}

Lazarev, S., Oms, O., Bukhsianidze, M., Vasilyan, D., Kuiper, K., Bouwmeester, M.L., Jorissen, E.L., Aghayeva, V., Krijgsman, W. The Plio-Pleistocene Akchagylian Flooding in the westernmost Kura Basin (South Caspian region): New and revised magnetostratigraphic and ${ }^{40} \mathrm{Ar} /{ }^{39} \mathrm{Ar}$ age constraints.

Vasiliev, I., Stoica, M., Grothe, A., Lazarev, S., Palcu, D., van Baak, C., de Leeuw, A., Sangiorgi, F., Reichart, G., Davies, G., Krijgsman, W. Hydrological changes in restricted basins: insights from strontium isotopes on late Miocene-Pliocene connectivity of the Dacian Basin (Eastern Paratethys, Romania)

Krijgsman, W., Stoica, M., Hoyle, T., Jorissen, E., Lazarev, S., Rausch, L., Bista, D., Alcicek,C., Ilgar, A., van den Hoek Ostende, L., Mayda, S., Raffi, I., Flecker, R., Mandic, O., Neubauer, T., Wesselingh, F. The myth of the Messinian Dardanelles: late Miocene stratigraphy and paleogeography of the ancient Aegean-Black Sea gateway.

Lazarev, S., Wesselingh, F. P., Rausch, L., Alçiçek, C., Neubauer, T., Stoica, M., Hoyle, T., Sangiorgi, F., Abels, H., van Baak, C., Bista D., Krijgsman, W. Constraining biogeographic evolution at continental crossroads: Age and environmental evolution of the Late Neogene Denizli Basin succession (Turkey).

Lazarev, S., Rausch, L., Abels, H., Alçiçek, C., Wesselingh, F., Stoica, M., van Baak, C., Krijgsman, W. Depositional architecture and drivers of sublacustrine channel-fans in the extensional Denizli Basin (early Zanclean, SW Anatolia). 



\section{REFERENCES}

Abdullayev, N.A., Kadirov, F., Guliyev, I.S., 2017. Subsidence history and basin-fill evolution in the South Caspian Basin from geophysical mapping, flexural backstripping, forward lithospheric modelling and gravity modelling. Geological Society, London, Special Publications 427, 175-196. 10.1144/SP427.5.

Abdullayev, N.R., Riley, G.W., Bowman, A.P., 2012. Regional controls on lacustrine sandstone reservoirs: the Pliocene of the South Caspian Basin.

Abdullayev, N.R., Weber, J., van Baak, C.G.C., Aliyeva, E., Leslie, C., Riley, G.W., O’Sullivan, P., Kislitsiyn, R., 2018. Detrital zircon and apatite constraints on depositional ages, sedimentation rates and provenance: Pliocene Productive Series, South Caspian Basin, Azerbaijan. Basin Res 30, 835-862. 10.1111/bre.12283.

Agalarova, D.A., 1967. Microfauna der Ponthischen Ablagerungen Aserbeidschans und der angrenzenden Gebiete. Az NII po Dobyce Nefti A 204, 123.

Agalarova, D.A., Kadyrova, Z.K., Kulieva, S.A., 1961. Ostracoda from Pliocene and Post-pliocene de-posits of Azerbaijan. Azerbaijan state publisher, Baku, 420 pp.

Agustí, J., Vekua, A., Oms, O., Lordkipanidze, D., Bukhsianidze, M., Kiladze, G., Rook, L., 2009. The Pliocene-

Pleistocene succession of Kvabebi (Georgia) and the background to the early human occupation of Southern Caucasus. Quaternary Science Reviews 28, 3275-3280. 10.1016/j.quascirev.2009.09.001.

Alania, V.M., Chabukiani, A.O., Chagelishvili, R.L., Enukidze, O.V., Gogrichiani, K.O., Razmadze, A.N., Tsereteli, N.S., 2017. Growth structures, piggy-back basins and growth strata of the Georgian part of the Kura foreland fold-thrust belt: implications for Late Alpine kinematic evolution. Geological Society, London, Special Publications 428, 171-185. 10.1144/SP428.5.

Alçiçek, H., 2010. Stratigraphic correlation of the Neogene basins in southwestern Anatolia: Regional palaeogeographical, palaeoclimatic and tectonic implications. Palaeogeography, Palaeoclimatology, Palaeoecology 291, 297-318. 10.1016/j.palaeo.2010.03.002.

Alçiçek, H., Jiménez-Moreno, G., 2013. Late Miocene to Plio-Pleistocene fluvio-lacustrine system in the Karacasu Basin (SW Anatolia, Turkey): Depositional, paleogeographic and paleoclimatic implications. Sedimentary Geology 291, 62-83. 10.1016/j.sedgeo.2013.03.014.

Alçiçek, H., Varol, B., Özkul, M., 2007a. Sedimentary facies, depositional environments and palaeogeographic evolution of the Neogene Denizli Basin, SW Anatolia, Turkey. Sedimentary Geology 202, 596-637. 10.1016/j. sedgeo.2007.06.002.

Alçiçek, H., Wesselingh, F.P., Alçiçek, M.C., 2015. Paleoenvironmental evolution of the late Pliocene-early Pleistocene fluvio-deltaic sequence of the Denizli Basin (SW Turkey). Palaeogeography, Palaeoclimatology, Palaeoecology 437, 98-116. 10.1016/j.palaeo.2015.06.019. 
Alçiçek, M.C., 2007b. Tectonic development of an orogen-top rift recorded by its terrestrial sedimentation pattern: The Neogene Eşen Basin of southwestern Anatolia, Turkey. Sedimentary Geology 200, 117-140. 10.1016/j.sedgeo.2007.04.003.

Alçiçek, M.C., Brogi, A., Capezzuoli, E., Liotta, D., Meccheri, M., 2013. Superimposed basin formation during Neogene-Quaternary extensional tectonics in SW-Anatolia (Turkey): Insights from the kinematics of the Dinar Fault Zone. Tectonophysics 608, 713-727. 10.1016/j.tecto.2013.08.008.

Alçiçek, M.C., Mayda, S., Veen, J.H. ten, Boulton, S.J., Neubauer, T.A., Alçiçek, H., Tesakov, A.S., Saraç, G., Hakyemez, H.Y., Göktaş, F., Murray, A.M., Titov, V.V., Jiménez-Moreno, G., Büyükmeriç, Y., Wesselingh, F.P., Bouchal, J.M., Demirel, F.A., Kaya, T.T., Halaçlar, K., Bilgin, M., van den Hoek Ostende, L.W., 2019. Reconciling the stratigraphy and depositional history of the Lycian orogen-top basins, SW Anatolia. Palaeobio Palaeoenv 99, 551-570. 10.1007/s12549-019-00394-3.

Aliyeva, E.G.M., 2005. Reservoirs of the Lower Pliocene Productive Series at the Western Flank of the South Caspian Basin. Lithol Miner Resour 40, 267-278. 10.1007/s10987-005-0027-7.

Ali-Zade, A.A., 1961. Ackhagylian of Turkmenistan. GOSGEOLTEKHIZDAT, Moscow.

Ali-Zade, A.A., Alizade, K.A., Gabuniya, L.K., Negadaev-Nikonov, K.N., Nikiforova, K.V. (Eds.), 1972.

International colloquium on the Neogene Quaternary boundary. Guidebook. Excursions in Moldavia, Georgia, Azerbaijan, May-June, 1972 (INQUA - IUGS Neogene Subcommission), Moscow.

Alizadeh, A.A., Guliyev, I.S., Kadirov, F.A., Eppelbaum, L.V., 2016. Geosciences of Azerbaijan. Springer International Publishing, Cham.

Allen, J.L., Johnson, C.L., 2011. Architecture and formation of transgressive-regressive cycles in marginal marine strata of the John Henry Member, Straight Cliffs Formation, Upper Cretaceous of Southern Utah, USA.

Sedimentology 58, 1486-1513. 10.1111/j.1365-3091.2010.01223.x.

Allen, M.B., Jones, S., Ismail-Zadeh, A., Simmons, M., Anderson, L., 2002. Onset of subduction as the cause of rapid Pliocene-Quaternary subsidence in the South Caspian basin. Geol 30, 775. 10.1130/0091-7613(2002)030<0775:OOSATC>2.0.CO;2.

Allen, M.B., Vincent, S.J., Alsop, G.I., Ismail-Zadeh, A., Flecker, R., 2003. Late Cenozoic deformation in the South Caspian region: Effects of a rigid basement block within a collision zone. Tectonophysics 366, 223-239. 10.1016/S0040-1951(03)00098-2.

Allen, P.A., Densmore, A.L., 2000. Sediment flux from an uplifting fault block. Basin Res 12, 367-380. 10.1111/j.1365-2117.2000.00135.x.

Amorosi, A., Centineo, M.C., Colalongo, M.L., Pasini, G., Sarti, G., Vaiani, S.C., 2003. Facies Architecture and Latest Pleistocene-Holocene Depositional History of the Po Delta (Comacchio Area), Italy. The Journal of Geology 111, 39-56. 10.1086/344577.

Amorosi, A., Maselli, V., Trincardi, F., 2016. Onshore to offshore anatomy of a late Quaternary source-to-sink system (Po Plain-Adriatic Sea, Italy). Earth-Science Reviews 153, 212-237. 10.1016/j.earscirev.2015.10.010.

Andrusov, N., 1902. Beiträge zur Kenntniss des Kaspischen Neogen. Die Aktschagylschichten. Proceedings of the Geological Committee 15. 
Andrusov, N., 1918. Relationships of Euxinian and Caspian Basins in the Neogene Epoch. Bulletin of the Russian Academy of Sciences.

Andrusov, N.I., 1923. Apsheronian Stage. Proceedings of the Geological Comitee.

Anistratenko, V.V., 2008. Evolutionary trends and relationships in hydrobiids (Mollusca, Caenogastropoda) of the Azov-Black Sea Basin in the light of their comparative morphology and paleozoogeography. Zool. Reihe 84, 129-142. 10.1002/zoos.200800001.

Anoykin, A.A., Rybalko, A.G., 2013. Early Paleolithic industries of the Dagestan seaside (based on materials form the Rubas-1 locality) (In Russian). Novosibirsk State University Bulletin 12, 85-96.

Arslanov, N.V., Lokshin, A.V., Mamedov, A.V., 1988. On age constraints of Khazarian, Khvalynian and Neocaspian deposits of the Caspian Sea. Bulletin of the Commission for the Study of the Quaternary Period, $28-38$.

Asadullayev, E.M., Pevzner, M.A., 1973. Paleomagnetic investigations of marine Anthropohene deposits of the Maliy Kharami ridge. Izv.Acad.Sci. USSR, Ser. Geol. 1.

Azizbekov, S.A. (Ed.), 1972. Geology of the USSR: Azerbaijan SSR. Nedra, Moscow.

Bairamov, A.A., Aliyev G.I., Hasanov, G.M., Hasanov, H.Y., Hasanov, T.A., Ismail-Zadeh, A.J., Kangarli, T.N., Korobanov, V.V., Mamedov, A.I., Mamedov, A.V., Mustafayev, H.V., Nagiyev, A.N., Narimanov, A.A., Rustamov, M.I., Zamanov, Y.J., 2008. Geological map of Azerbaijan Republic. National Academy of Sciences of Azerbaijan Republic, Ministry of Ecology and Natural Resources of Azerbaijan Republic and Ministry of Fuel and Energetics of Azerbaijan Republic, Baku.

Basilici, G., 1997. Sedimentary facies in an extensional and deep-lacustrine depositional system: the Pliocene Tiberino Basin, Central Italy. Sedimentary Geology 109, 73-94. 10.1016/S0037-0738(96)00056-5.

Bhattacharya, J.P., MacEachern, J.A., 2009. Hyperpycnal Rivers and Prodeltaic Shelves in the Cretaceous Seaway of North America. Journal of Sedimentary Research 79, 184-209. 10.2110/jsr.2009.026.

Bista, D., 2019. Reconstructing the Pleistocene connectivity history of the Black Sea And the Caspian Sea using strontium iotopes. Doctoral thesis, Bristol.

Bludorova, E.A., Vasiliev, Y.M., Zhidovinov, N.Y., Karmishina, G.I., Nemkova, V.K., Nikiforova, K.V., PopovaLvova, M.G., Chiguryaeva, A.A., Yakhimovich, V.L., 1983. Apsheronian time of the East-European Plain. Bulletin of the Commission for the Study of the Quaternary Period, 3-17.

Bogachev, V.V., 1940. Apsheronian fauna in the Azov Sea Basin. Nature (Priroda), 74.

Bohacs, K.M., Carroll, A.R., Neal, J.E., 2003. Lessons from large lake systems-Thresholds, nonlinearity, and strange attractors. In: Chan, M.A., Archer, A.W. (Eds.) Extreme depositional environments: mega end members in geologic time. Geological Society of America.

Borissjak, A.A. (Ed.), 1937. Stratigraphical Dictionary of the USSR. ONTI NKTP USSR, Moscow, Leningrad. Bouma, A., 1964. Turbidites. In: Turbidites, vol. 3. Elsevier, pp. 247-256.

Brunet, M.-F., Korotaev, M.V., Ershov, A.V., Nikishin, A.M., 2003. The South Caspian Basin: a review of its evolution from subsidence modelling. Sedimentary Geology 156, 119-148. 10.1016/S0037-0738(02)00285-3. 
Buatois, L.A., Santiago, N., Herrera, M., Plink-Björklund, P., Steel, R.O.N., Espin, M., Parra, K., 2012.

Sedimentological and ichnological signatures of changes in wave, river and tidal influence along a Neogene tropical deltaic shoreline. Sedimentology 59, 1568-1612. 10.1111/j.1365-3091.2011.01317.x.

Bukhsianidze, M., Koiava, K., 2018. Synopsis of the terrestrial vertebrate faunas from the Middle Kura Basin (Eastern Georgia and Western Azerbaijan, South Caucasus). APP 63. 10.4202/app.00499.2018.

Bukowski, G.v., 1896. Die levantinische Molluskenfauna der Insel Rhodus, II. Theil. Schluss. Denkschriften der Kaiserlichen Akademie der Wissenschaften, Mathematisch-Naturwissenschaftliche Classe 63, 1-70.

Büyükmeriç, Y., Wesselingh, F.P., 2018. New cockles (Bivalvia: Cardiidae: Lymnocardiinae) from Late Pleistocene Lake Karapınar (Turkey): Discovery of a Pontocaspian refuge? Quaternary International 465, 37-45. 10.1016/j.quaint.2016.03.018.

Capella, W., Barhoun, N., Flecker, R., Hilgen, F.J., Kouwenhoven, T., Matenco, L.C., Sierro, F.J., Tulbure, M.A., Yousfi, M.Z., Krijgsman, W., 2018. Palaeogeographic evolution of the late Miocene Rifian Corridor (Morocco): Reconstructions from surface and subsurface data. Earth-Science Reviews 180, 37-59. 10.1016/j. earscirev.2018.02.017.

Carbonnel, G., 1969. Les ostracodes du Miocène Rhodanien: Systématique, biostratigraphie écologique, paléobiologie. Lyon University, Lyon, 469 pp.

Catuneanu, O., Abreu, V., Bhattacharya, J.P., Blum, M.D., Dalrymple, R.W., Eriksson, P.G., Fielding, C.R., Fisher, W.L., Galloway, W.E., Gibling, M.R., Giles, K.A., Holbrook, J.M., Jordan, R., Kendall, C.G.S.C., Macurda, B., Martinsen, O.J., Miall, A.D., Neal, J.E., Nummedal, D., Pomar, L., Posamentier, H.W., Pratt, B.R., Sarg, J.F., Shanley, K.W., Steel, R.J., Strasser, A., Tucker, M.E., Winker, C., 2009. Towards the standardization of sequence stratigraphy. Earth-Science Reviews 92, 1-33. 10.1016/j.earscirev.2008.10.003.

Çemen, I., Catlos, E.J., Gögüs, O., Özerdem, C., 2006. Postcollisional extensional tectonics and exhumation of the Menderes massif in the Western Anatolia extended terrane, Turkey. In: Dilek, Y., Pavlides, S. (Eds.) Postcollisional Tectonics and Magmatism in the Mediterranean Region and Asia, v. 14. Geological Society of America, p. 71.

Chang, L., Vasiliev, I., van Baak, C., Krijgsman, W., Dekkers, M.J., Roberts, A.P., Gerald, J.D.F., van Hoesel, A., Winklhofer, M., 2014. Identification and environmental interpretation of diagenetic and biogenic greigite in sediments: A lesson from the Messinian Black Sea. Geochem. Geophys. Geosyst. 15, 3612-3627. 10.1002/2014GC005411.

Channell, J.E.T., 2017. Cobb Mountain Subchron recorded at IODP Site U1306 (Eirik Drift, off SE Greenland). Geophys. J. Int. 209, 1389-1397. 10.1093/gji/ggx098.

Checa, A.G., Jiménez-López, C., Rodríguez-Navarro, A., Machado, J.P., 2007. Precipitation of aragonite by calcitic bivalves in Mg-enriched marine waters. Mar Biol 150, 819-827. 10.1007/s00227-006-0411-4.

Cheel, R., 1978. Hummocky and swaley cross-stratification. In: Sedimentology. Springer Berlin Heidelberg, pp. 585-588.

Chentnik, B.M., Johnson, C.L., Mulhern, J.S., Stright, L., 2015. Valleys, Estuaries, and Lagoons:

Paleoenvironments and Regressive-Transgressive Architecture of the Upper Cretaceous Straight Cliffs Formation, Utah, U.S.A. Journal of Sedimentary Research 85, 1166-1196. 10.2110/jsr.2015.70. 
Çiftçi, N.B., Bozkurt, E., 2009. Structural evolution of the Gediz Graben, SW Turkey: temporal and spatial variation of the graben basin. Basin Res 173, 385. 10.1111/j.1365-2117.2009.00438.x.

Clark, J.D., Pickering, K.T., 1996. Architectural Elements and Growth Patterns of Submarine Channels: Application to Hydrocarbon Exploration. Bulletin 80. 10.1306/64ED878C-1724-11D7-8645000102C1865D.

Collinson, J.D., 1969. The Sedimentology of the Grindslow Shales and the Kinderscout Grit: A Deltaic Complex in the Namurian of Northern England. Journal of Sedimentary Research Vol. 39. 10.1306/74D71C17-2B2111D7-8648000102C1865D.

Covault, J.A., 2011. Submarine fans and canyon-channel systems: a review of processes, products, and models. Nature Education Knowledge 3, 4.

Cronin, B., Owen, D., Hartley, A., Kneller, B., 1998. Slumps, debris flows and sandy deep-water channel systems: implications for the application of sequence stratigraphy to deep water clastic sediments. Journal of the Geological Society 155, 429-432. 10.1144/gsigs.155.3.0429.

Danukalova, G.'A., 1996. Bivalves and stratigraphy of the Akchagylian. Nauka, Moscow, 104, XXIV Seiten, Seite 105-130.

De Leeuw, A., Bukowski, K., Krijgsman, W., Kuiper, K.F., 2010. Age of the Badenian salinity crisis; impact of Miocene climate variability on the circum-Mediterranean region. Geol 38, 715-718. 10.1130/G30982.1.

De Leeuw, A., Tulbure, M., Kuiper, K.F., Melinte-Dobrinescu, M.C., Stoica, M., Krijgsman, W., 2018. New 40Ar/39Ar, magnetostratigraphic and biostratigraphic constraints on the termination of the Badenian Salinity Crisis: Indications for tectonic improvement of basin interconnectivity in Southern Europe. Global and Planetary Change 169, 1-15. 10.1016/j.gloplacha.2018.07.001.

Dean, W.E., Fouch, T.D., 1983a. Lacustrine environment. In: Scholle, P.A., Bebout, D., Moore, C. (Eds.) Carbonate depositional environments. American Association of Petroleum geologits Memoire.

Dean, W.E., Fouch, T.D., 1983b. Lacustrine environment. In: Scholle, P.A., Bebout, D., Moore, C. (Eds.) Carbonate depositional environments. American Association of Petroleum geologits Memoire.

Derevianko, A., Anoykin, A., Kazansky, A., Matasova, G., 2015. New Data to Justify the Age of Early Paleolithic Artifacts of Rubas-1 Site (Seaside Dagestan). izvasu. 10.14258/izvasu(2015)3.2-11.

Di Celma, C.N., Brunt, R.L., Hodgson, D.M., Flint, S.S., Kavanagh, J.P., 2011. Spatial and Temporal Evolution of a Permian Submarine Slope Channel-Levee System, Karoo Basin, South Africa. Journal of Sedimentary Research 81, 579-599. 10.2110/jsr.2011.49.

Djikia, N., 1968. Historical Development of Akchagylian Malacofauna from Eastern Georgia.: (in Russian). Mecniereba, Tbilisi.

Dodd, T.J.H., McCarthy, D.J., Richards, P.C., 2019. A depositional model for deep-lacustrine, partially confined, turbidite fans: Early Cretaceous, North Falkland Basin. Sedimentology 66, 53-80. 10.1111/sed.12483.

Doğan, A., Mayda, S., Alçiçek, M.C., 2020. Denizli Havzası (GB Anadolu) Neojen istifinde ilk Turoliyen bulgusu ve bölgesel paleobiyocoğrafik önemi. Bulletin Of The Mineral Research and Exploration 162, 1-10. 10.19111/ bulletinofmre.651620.

Dott, R.H., Bourgeois, J., 1982. Hummocky stratification: Significance of its variable bedding sequences. Geol Soc America Bull 93, 663. 10.1130/0016-7606(1982)93<663:HSSOIV>2.0.CO;2. 
Dumitrescu, I., Sandulescu, M., Bandrabur, T., 1970. Geologic map of Romania: Covasna sheet.

Dunlop, D.J., Ozdemir, O., 1997. Rock Magnetism. Cambridge University Press, Cambridge.

Dupont-Nivet, G., Vasiliev, I., Langereis, C.G., Krijgsman, W., Panaiotu, C., 2005. Neogene tectonic evolution of the southern and eastern Carpathians constrained by paleomagnetism. Earth and Planetary Science Letters 236, 374-387. 10.1016/j.epsl.2005.04.030.

Fedorov, P.V., 1957. Stratigraphy of the Quaternary deposits and history of the Caspian Sea development. AS USSR, Proceedings of the Geological Institute.

Fielding, C.R., 2010. Planform and Facies Variability in Asymmetric Deltas: Facies Analysis and Depositional Architecture of the Turonian Ferron Sandstone in the Western Henry Mountains, South-Central Utah, U.S.A. Journal of Sedimentary Research 80, 455-479. 10.2110/jsr.2010.047.

Fisher, R., 1953. Dispersion on a Sphere. Proceedings of the Royal Society A: Mathematical, Physical and Engineering Sciences 217, 295-305. 10.1098/rspa.1953.0064.

Flecker, R., Krijgsman, W., Capella, W., Castro Martíns, C. de, Dmitrieva, E., Mayser, J.P., Marzocchi, A., Modestou, S., Ochoa, D., Simon, D., Tulbure, M., van den Berg, B., van der Schee, M., Lange, G. de, Ellam, R., Govers, R., Gutjahr, M., Hilgen, F., Kouwenhoven, T., Lofi, J., Meijer, P., Sierro, F.J., Bachiri, N., Barhoun, N., Alami, A.C., Chacon, B., Flores, J.A., Gregory, J., Howard, J., Lunt, D., Ochoa, M., Pancost, R., Vincent, S., Yousfi, M.Z., 2015. Evolution of the Late Miocene Mediterranean-Atlantic gateways and their impact on regional and global environmental change. Earth-Science Reviews 150, 365-392. 10.1016/j. earscirev.2015.08.007.

Flügel, E., 2010. Microfacies of Carbonate Rocks: Analysis, Interpretation and Application, 2nd ed. SpringerVerlag Berlin Heidelberg, Berlin, Heidelberg, 984 pp.

Fongngern, R., Olariu, C., Steel, R., Mohrig, D., Krézsek, C., Hess, T., 2018. Subsurface and outcrop characteristics of fluvial-dominated deep-lacustrine clinoforms. Sedimentology 65, 1447-1481. 10.1111/sed.12430.

Forte, A.M., Cowgill, E., Bernardin, T., Kreylos, O., Hamann, B., 2010. Late Cenozoic deformation of the Kura fold-thrust belt, southern Greater Caucasus. Tectonophysics 122, 465-486. 10.1130/B26464.1.

Forte, A.M., Cowgill, E., Murtuzayev, I., Kangarli, T., Stoica, M., 2013. Structural geometries and magnitude of shortening in the eastern Kura fold-thrust belt, Azerbaijan: Implications for the development of the Greater Caucasus Mountains. Tectonics 32, 688-717. 10.1002/tect.20032.

Forte, A.M., Sumner, D.Y., Cowgill, E., Stoica, M., Murtuzayev, I., Kangarli, T., Elashvili, M., Godoladze, T., Javakhishvili, Z., 2015. Late Miocene to Pliocene stratigraphy of the Kura Basin, a subbasin of the South Caspian Basin: Implications for the diachroneity of stage boundaries. Basin Res 27, 247-271. 10.1111/ bre.12069.

Forzoni, A., Hampson, G., Storms, J., 2015. Along-Strike Variations In Stratigraphic Architecture of ShallowMarine Reservoir Analogues: Upper Cretaceous Panther Tongue Delta and Coeval Shoreface, Star Point Sandstone, Wasatch Plateau, Central Utah, U.S.A. Journal of Sedimentary Research 85, 968-989. 10.2110/ jsr.2015.69. 
Forzoni, A., Storms, J.E.A., Whittaker, A.C., Jager, G. de, 2014. Delayed delivery from the sediment factory: modeling the impact of catchment response time to tectonics on sediment flux and fluvio-deltaic stratigraphy. Earth Surf. Process. Landforms 39, 689-704. 10.1002/esp.3538.

Freels, F., 1980. Limnische Ostrakoden aus Jungtertiar und Quartar der Turkei. Geologisches Jahrbuch 39, 3-169.

Fuchs, T., 1877. Studien über die jüngeren Tertiärbildungen Griechenlands. Denkschriften der Kaiserlichen Akademie der Wissenschaften, Mathematisch-Naturwissenschaftliche Classe 37, 1-42.

Gautier, P., Brun, J.-P., Moriceau, R., Sokoutis, D., Martinod, J., Jolivet, L., 1999. Timing, kinematics and cause of Aegean extension: a scenario based on a comparison with simple analogue experiments. Tectonophysics 315, 31-72. 10.1016/S0040-1951(99)00281-4.

Gawthorpe, R.L., Leeder, M.R., 2000. Tectono-sedimentary evolution of active extensional basins. Basin Research 12, 195-218. 10.1111/j.1365-2117.2000.00121.x.

Gillet, H., Lericolais, G., Réhault, J.-P., 2007. Messinian event in the Black Sea: Evidence of a Messinian erosional surface. Marine Geology 244, 142-165. 10.1016/j.margeo.2007.06.004.

Gladenkov, A.Y. (Ed.), 2018. Neogene and Quaternary of Russia: stratigraphy, events and paleogeography. GEOS, Moscow.

Gliozzi, E., Rodriguez-Lazaro, J., Nachite, D., Martin-Rubio, M., Bekkali, R., 2005. An overview of Neogene brackish leptocytherids from Italy and Spain: Biochronological and palaeogeographical implications. Palaeogeography, Palaeoclimatology, Palaeoecology 225, 283-301. 10.1016/j.palaeo.2005.06.015.

2018. Global warming of $1.5^{\circ} \mathrm{C}$. IPCC, [Geneva, Switzerland], 1 online resource.

Glöer, P., 2019. The Freshwater Gastropods of the West-Palaearctis.: Volume I. Fresh- and brackish waters except spring and subterranean snails. Identification key, Anatomy, Ecology, Distribution.

Golovina, L.A., Radionova, E.P., van Baak, C.G.C., Krijgsman, W., Palcu, D.V., 2019. A Late Maeotian age (6.7-6.3 Ma) for the enigmatic "Pebbly Breccia" unit in DSDP Hole 380A of the Black Sea. Palaeogeography, Palaeoclimatology, Palaeoecology, 109269. 10.1016/j.palaeo.2019.109269.

Gramann, F., Kockel, F., 1969. Das Neogen im Strimonbecken (Griechisch Ostmazedonien). Geologisches Jahrbuch 87, 445-484.

Green, T., Abdullayev, N., Hossack, J., Riley, G., Roberts, A.M., 2009. Sedimentation and subsidence in the South Caspian Basin, Azerbaijan. Geological Society, London, Special Publications 312, 241-260. 10.1144/SP312.12.

Grothe, A., 2016. The Messinian salinity crisis: a Paratethyan perspective: De Messiniaanse zoutcrisis: een Paratethys' perspectief. Ridderprint BV, Ridderkerk, 151 pp.

Grothe, A., Andreetto, F., Reichart, G.-J., Wolthers, M., van Baak, C.G.C., Vasiliev, I., Stoica, M., Sangiorgi, F., Middelburg, J.J., Davies, G.R., Krijgsman, W., 2020. Paratethys pacing of the Messinian Salinity Crisis: Low salinity waters contributing to gypsum precipitation? Earth and Planetary Science Letters 532, 116029. 10.1016/j.epsl.2019.116029.

Grothe, A., Sangiorgi, F., Brinkhuis, H., Stoica, M., Krijgsman, W., 2018. Migration of the dinoflagellate Galeacysta etrusca and its implications for the Messinian Salinity Crisis. Newsl. Stratigr. 51, 73-91. 10.1127/ nos/2016/0340. 
Grothe, A., Sangiorgi, F., Mulders, Y.R., Vasiliev, I., Reichart, G.-J., Brinkhuis, H., Stoica, M., Krijgsman, W., 2014. Black Sea desiccation during the Messinian Salinity Crisis: Fact or fiction? Geol 42, 563-566. 10.1130/ G35503.1.

Guerra-Merchán, A., Serrano, F., Garcés, M., Gofas, S., Esu, D., Gliozzi, E., Grossi, F., 2010. Messinian LagoMare deposits near the Strait of Gibraltar (Malaga Basin, S Spain). Palaeogeography, Palaeoclimatology, Palaeoecology 285, 264-276. 10.1016/j.palaeo.2009.11.019.

Gurarii, G.Z., 2015. Some data on the characteristics of the geomagnetic field at the Gauss-Matuyama magnetic chron boundary from the Pirnuar section, West Turkmenistan. Izv., Phys. Solid Earth 51, 651-673. 10.1134/ S1069351315050055.

Gürer, O.F., Sarica-Filoreau, N., Özburan, M., Sangu, E., Doğan, B., 2009. Progressive development of the Büyük Menderes Graben based on new data, western Turkey. Geological magazine 146, 652-673.

Haase, M., Naser, M.D. \& Wilke, T., 2010. Ecrobia grimmi in brackish Lake Sawa, Iraq: indirect evidence for longdistance dispersal of hydrobiid gastropods (Caenogastropoda: Rissooidea) by birds. Journal of Molluscan Studies 76, 101-105.

Hampson, G.J., Sixsmith, P.J., Kieft, R.L., Jackson, C.A.-L., Johnson, H.D., 2009. Quantitative analysis of nettransgressive shoreline trajectories and stratigraphic architectures: mid-to-late Jurassic of the North Sea rift basin. Basin Res 21, 528-558. 10.1111/j.1365-2117.2009.00414.x.

Hartmann, G., 1959. Dr. H.G. Bronn's Klassen und Ordnungen des Tierreichs. 5. Arthropoda, 1. Crustacea, 2(4/1). Akadem. Verl.-Ges. Geest \& Portig, Leipzig, 216 pp.

Hayes, M.O., FitzGerald, D.M., 2013. Origin, Evolution, and Classification of Tidal Inlets. Journal of Coastal Research 69,14-33. 10.2112/SI_69_3.

Herbert, T.D., Lawrence, K.T., Tzanova, A., Peterson, L.C., Caballero-Gill, R., Kelly, C.S., 2016. Late Miocene global cooling and the rise of modern ecosystems. Nature Geosci 9, 843-847. 10.1038/NGEO2813.

Hickson, T.A., Lowe, D.R., 2002. Facies architecture of a submarine fan channel-levee complex: the Juniper Ridge Conglomerate, Coalinga, California. Sedimentology 49, 335-362. 10.1046/j.1365-3091.2002.00447.x.

Hilgen, F.J., Kuiper, K., Krijgsman, W., Snel, E., van der Laan, E., 2007. Astronomical tuning as the basis for high resolution chronostratigraphy: the intricate history of the Messinian Salinity Crisis. Stratigraphy 4, 231-238.

Hilgen, F.., Lourens, L.J., van Dam, J.A., Beu, A.G., Boyes, A.F., Cooper, R.A., Krijgsman, W., Ogg, J.G., Piller, W.E., Wilson, D.S., 2012. The Neogene Period. In: The Geologic Time Scale. Elsevier, pp. 923-978.

Hiscott, R.N., Hall, F.R., Pirmez, C., 1997. Turbidity-current overspill from the Amazon Channel: texture of the silt/sand load, paleoflow from anisotropy of magnetic susceptibility, and implications for flow processes. In: Flood, R.D., Piper, D.J.W., Klaus, A., Peterson, L.C. (Eds.) Proceedings of the Ocean Drilling Program, 155 Scientific Results, vol. 155. Ocean Drilling Program.

Hodell, D.A., Curtis, J.H., Sierro, F.J., Raymo, M.E., 2001. Correlation of Late Miocene to Early Pliocene sequences between the Mediterranean and North Atlantic. Paleoceanography 16, 164-178. 10.1029/1999PA000487.

Hodgson, D.M., Flint, S.S., Hodgetts, D., Drinkwater, N.J., Johannessen, E.P., Luthi, S.M., 2006. Stratigraphic Evolution of Fine-Grained Submarine Fan Systems, Tanqua Depocenter, Karoo Basin, South Africa. Journal of Sedimentary Research 76, 20-40. 10.2110/jsr.2006.03. 
Hoyle, T.M., 2019a. Biotic change and landlocked seas: Ecosystem responses to climate and sea level variability in the Plio-Pleistocene of the Pontocaspian basins = Boitopische veranderingen en binnenzeeën : de reactie van ecosystemen op klimaat en zeespiegelveranderingen in de Pontokaspische bekkens tijdens het PlioPleistoceen. Utrecht University, Faculty of Geosciences, Department of Earth Sciences, [Utrecht], 244 pagina's.

Hoyle, T.M., Leroy, S.A.G., Lopez-Merino, L., Miggins, D.P., Koppers, A. A. A. P.:, 2019b. Vegetation succession and climate change across the Plio-Pleistocene transition in central Eurasia (2.8-2.5 Ma): (submitted). Palaeogeography, Palaeoclimatology, Palaeoecology.

Hsü, K.J., Ryan, W.B.F., Cita, M.B., 1973. Late Miocene Desiccation of the Mediterranean. Nature 242, $240-244$. 10.1038/242240a0.

Iljina, L.A., Nevesskaja, L.A., Paramonova, N.P., 1976. Regularities of mollusc development in the Neogene semimarine and brackishwater basins of Eurasia (Late Miocene - Early Pliocene). Publishing house "Nauka", Moscow.

Ivanov, D., Utescher, T., Mosbrugger, V., Syabryaj, S., Djordjević-Milutinović, D., Molchanoff, S., 2011. Miocene vegetation and climate dynamics in Eastern and Central Paratethys (Southeastern Europe). Palaeogeography, Palaeoclimatology, Palaeoecology 304, 262-275. 10.1016/j.palaeo.2010.07.006.

Jackson, J., Priestley, K., Allen, M., Berberian, M., 2002. Active tectonics of the South Caspian Basin. Geophysical Journal International 148, 214-245. 10.1046/j.1365-246X.2002.01005.x.

Jekelius, E., 1944. Sarmat und Pont von Soceni (Banat). Memoriile Institutului Geolologic al României.

Jipa, D., Olariu, C., 2009. Dacian Basin: Depositional architecture and sedimentary history of a Paratethys Sea. GeoEcoMar, Bucharest, 264 pp.

Jiřiček, R., 1985. Die Ostracoden des Pannonien. In: Papp, A., Jámbor, Á., Steininger, F.F. (Eds.) Miozän der Zentralen Paratethys. Pannonien: Slavonien und Serbien, vol. 7. Akadémiai Kiadó, Ungarische Akademie der Wissenschaften, Budapest, pp. 378-425.

Johnson, S.D., Flint, S., Hinds, D., Ville Wickens, H. de, 2001. Anatomy, geometry and sequence stratigraphy of basin floor to slope turbidite systems, Tanqua Karoo, South Africa. Sedimentology 48, 987-1023. 10.1046/j.1365-3091.2001.00405.x.

Jones, R.W., Simmons, M., 1997. A review of the stratigraphy of Eastern Paratethys (Oligocene-Holocene), with particular emphasis on the Black Sea. AAPG Memoir.

Jorissen, E., Abels, H., Wesselingh, F., Lazarev, S., Aghayeva, V., Krijgsman, W., 2019. Amplitude, frequency and drivers of Caspian Sea lake-level variations during the Early Pleistocene and their impact on a protected wave-dominated coastline. Sedimentology. 10.1111/sed.12658.

Jorissen, E.L., 2020. The Pontocaspian basins in a grain of sand: Coastal sedimentary architecture, forcing mechanisms, and faunal turnover events in restricted basins. $\mathrm{PhD}$, Utrecht.

Jorissen, E.L., Leeuw, A. de, van Baak, C.G.C., Mandic, O., Stoica, M., Abels, H.A., Krijgsman, W., 2018.

Sedimentary architecture and depositional controls of a Pliocene river-dominated delta in the semi-isolated Dacian Basin, Black Sea. Sedimentary Geology 368, 1-23. 10.1016/j.sedgeo.2018.03.001. 
Kappes, H., Haase, P., 2012. Slow, but steady: dispersal of freshwater molluscs. Aquat Sci 74, 1-14. 10.1007/ s00027-011-0187-6.

Karami, M.P., De Leeuw, A., Krijgsman, W., Meijer, P.T., Wortel, M.J.R., 2011. The role of gateways in the evolution of temperature and salinity of semi-enclosed basins: An oceanic box model for the Miocene Mediterranean Sea and Paratethys. Global and Planetary Change 79, 73-88. 10.1016/j.gloplacha.2011.07.011.

Kaya, T.T., Mayda, S., Kostopoulos, D.S., Alcicek, M.C., Merceron, G., Tan, A., Karakutuk, S., Giesler, A.K., Scott, R.S., 2012. Şerefköy-2, a new Late Miocene mammal locality from the Yatağan Formation, Muğla, SW Turkey. Comptes Rendus Palevol 11, 5-12. 10.1016/j.crpv.2011.09.001.

Kaymakci, N., 2006. Kinematic development and paleostress analysis of the Denizli Basin (Western Turkey): implications of spatial variation of relative paleostress magnitudes and orientations. Journal of Asian Earth Sciences 27, 207-222. 10.1016/j.jseaes.2005.03.003.

Kayseri-Özer, M.S., 2017. Cenozoic vegetation and climate change in Anatolia - A study based on the IPR-vegetation analysis. Palaeogeography, Palaeoclimatology, Palaeoecology 467, 37-68. 10.1016/j. palaeo.2016.10.001.

Kazmin, V.G., Schreider, A.A., Bulychev, A.A., 2000. Early Stages of Evolution of the Black Sea. Geological Society, London, Special Publications 173, 235-249. 10.1144/GSL.SP.2000.173.01.12.

Kelder, N.A., Sant, K., Dekkers, M.J., Magyar, I., van Dijk, G.A., Lathouwers, Y.Z., Sztanó, O., Krijgsman, W., 2018. Paleomagnetism in Lake Pannon: Problems, Pitfalls, and Progress in Using Iron Sulfides for Magnetostratigraphy. Geochem. Geophys. Geosyst. 19, 3405-3429. 10.1029/2018GC007673.

Khain, V.E., Bogdanov, V.I., Popkov, V.I., Chekhovich, P.A., 2004. Major geostructures and basic features of the development of caspian oil and gas megabasins. Ecological bulletin of research centers of the Black Sea economic cooperation, 47-56.

Khain, V.E., Popkov, V.I. (Eds.), 2009. Tectonic of the south border of the East European platform: Explanatory letter to the tectonic mp of the Black Sea - Caspian Sea region. Scale 1:2500000. Kuban State University, Krasnodar.

Khramov, A.N., 1960. Paleomagnetism and stratigraphic correlation, Canberra.

Khramov, A.N., 1963. Paleomagnetic sections of Pliocene and Post-Pliocene of the Apsheronsk-Trancaucasian region and their correlation. Proceedings of the all Union Petroleum Research Exploration Institute (VNIGRI), 253-262.

Kieft, R.L., Hampson, G.J., Jackson, C.A.-L., Larsen, E., 2011. Stratigraphic Architecture of a Net-Transgressive Marginal- to Shallow-Marine Succession: Upper Almond Formation, Rock Springs Uplift, Wyoming, U.S.A. Journal of Sedimentary Research 81, 513-533. 10.2110/jsr.2011.44.

Kieft, R.L., Jackson, C.A.-L., Hampson, G.J., Larsen, E., 2010. Sedimentology and sequence stratigraphy of the Hugin Formation, Quadrant 15, Norwegian sector, South Viking Graben. Petroleum Geology Conference series 7, 157-176. 10.1144/0070157.

King, R.F., 1955. The remanent magnetism of artificially deposited sediments. Geophys. J. Int. 7, 115-134. 10.1111/j.1365-246X.1955.tb06558.x. 
Koç, A., Kaymakci, N., van Hinsbergen, D.J.J., Kuiper, K.F., 2017. Miocene tectonic history of the Central Tauride intramontane basins, and the paleogeographic evolution of the Central Anatolian Plateau. Global and Planetary Change 158, 83-102. 10.1016/j.gloplacha.2017.09.001.

Kochegura, V.V., Zubakov, V.A., 1978. Palaeomagnetic time scale of the Ponto-Caspian Plio-Pleistocene deposits. Palaeogeography, Palaeoclimatology, Palaeoecology 23, 151-160. 10.1016/0031-0182(78)90087-1.

Koçyiğit, A., 2005. The Denizli graben-horst system and the eastern limit of western Anatolian continental extension: basin fill, structure, deformational mode, throw amount and episodic evolutionary history, SW Turkey. Geodinamica Acta 18, 167-208. 10.3166/ga.18.167-208.

Kojumdgieva, E.I., 1969. Fosilite na Bulgaria VIII Sarmat., Sofija.

Kojumdgieva, E.I., Paramonova, N.P., Belokrys, K.S., Muskhelishvili, L.V., 1989. Ecostratigraphic subdivision of the Sarmatian after molluscs. Gologica Carpathica 40, 81-84.

Kolesnikov, V.P., 1950. The Akchagyl and Apsheron mollusks. Paleontology of the USSR 10-3.

Koppers, A.A.P., 2002. ArArCALC—software for 40Ar/39Ar age calculations. Computers \& Geosciences 28, 605-619. 10.1016/S0098-3004(01)00095-4.

Koymans, M.R., Langereis, C.G., Pastor-Galan, D., Hinsbergen, D.J.J., 2016. Paleomagnetism.org: An online multi-platform open source environment for paleomagnetic data analysis. Computers and Geosciences 93, $127-137$.

Krasnov, I.I. (Ed.), 1984. Stratigraphy of the USSR: Quaternary system. Nedra, Moscow.

Kraus, M.J., 1999. Paleosols in clastic sedimentary rocks: their geologic applications. Earth-Science Reviews 47, 41-70. 10.1016/S0012-8252(99)00026-4.

Krijgsman, W., Capella, W., Simon, D., Hilgen, F.J., Kouwenhoven, T.J., Meijer, P.T., Sierro, F.J., Tulbure, M.A., van den Berg, B.C.J., van der Schee, M., Flecker, R., 2018. The Gibraltar Corridor: Watergate of the Messinian Salinity Crisis. Marine Geology 403, 238-246. 10.1016/j.margeo.2018.06.008.

Krijgsman, W., Hilgen, F.J., Raffi, I., Sierro, F.J., Wilson, D.S., 1999. Chronology, causes and progression of the Messinian salinity crisis. Nature 400, 652 EP -. 10.1038/23231.

Krijgsman, W., Stoica, M., Vasiliev, I., Popov, V.V., 2010. Rise and fall of the Paratethys Sea during the Messinian Salinity Crisis. Earth and Planetary Science Letters 290, 183-191. 10.1016/j.epsl.2009.12.020.

Krijgsman, W., Tesakov, A., Yanina, T., Lazarev, S., Danukalova, G., van Baak, C.G.C., Agustí, J., Alçiçek, M.C., Aliyeva, E., Bista, D., Bruch, A., Büyükmeriç, Y., Bukhsianidze, M., Flecker, R., Frolov, P., Hoyle, T.M., Jorissen, E.L., Kirscher, U., Koriche, S.A., Kroonenberg, S.B., Lordkipanidze, D., Oms, O., Rausch, L., Singarayer, J., Stoica, M., van de Velde, S., Titov, V.V., Wesselingh, F.P., 2019. Quaternary time scales for the Pontocaspian domain: Interbasinal connectivity and faunal evolution. Earth-Science Reviews 188, 1-40. 10.1016/j.earscirev.2018.10.013.

Kroonenberg, S.B., Alekseevski, N.I., Aliyeva, E.G.M., Allen, M.B., Aybulatov, D. N., Baba-Zadeh, A., Badyukova, E.N., Davies, C.E., Hinds, D.J., Hoogendoorn, R.M., Huseynov, D., Ibrahimov, B., Mamedov, P., Overeem, I., Rusakov, G.V., Suleymanov, S., Svitoch, A.A., Vincent, S.J., 2005. Two deltas, two basins, one river, one sea:The modern Volga delta as an analogue of the Neogene Productive Series, South Caspian Basin. In: Giosan, L., Bhattacharya, J.P. (Eds.) River Deltas-Concepts, Models and Examples., pp. 231-255. 
Krstić, N., 1972. Roda Candona (Ostracoda) iz kongerijskich slojeva južnog dela Panonskog basena. Srpska akademija nauka i umetnosti 39, 1-145.

Krstić, N., 1973. Biostratigraphy of the congerian beds in the Belgrade region on the basis of Ostracoda with the description of the species of the genus Amplocypris. Institute for Geological and Mining Explorations and Investigation of Nuclear and Other Minerals Raw Materias, Monographs 4, 208.

Krstić, N., 1985. Ostracoden im Pannonien der Umgebung von Belgrad. In: Papp, A., Jámbor, Á., Steininger, F.F. (Eds.) Miozän der Zentralen Paratethys. Pannonien: Slavonien und Serbien. Akadémiai Kiadó, Ungarische Akademie der Wissenschaften, Budapest, pp. 103-143.

Krstić, N., 1989. Contribution by Ostracods to the definition of the boundaries of the Pontian in the Pannonian Basin. In: Stevanovic, P., Nevesskaya, L.A., Marinescu, F., Sokac, A., Jámbor, A. (Eds.) Neogen der Westlichen („Zentralen”) Paratethys, Pontien. JAZU \& SANU, Zagreb-Beograd, pp. 45-47.

Kuhlemann, J., Kempf, O., 2002. Post-Eocene evolution of the North Alpine Foreland Basin and its response to Alpine tectonics. Sedimentary Geology 152, 45-78. 10.1016/S0037-0738(01)00285-8.

Kuiper, K.F., Deino, A., Hilgen, F.J., Krijgsman, W., Renne, P.R., Wijbrans, J.R., 2008. Synchronizing rock clocks of Earth history. Science (New York, N.Y.) 320, 500-504. 10.1126/science.1154339.

La Vara, A. de, van Baak, C.G.C., Marzocchi, A., Grothe, A., Meijer, P.T., 2016. Quantitative analysis of Paratethys sea level change during the Messinian Salinity Crisis. Marine Geology 379, 39-51. 10.1016/j. margeo.2016.05.002.

Laskarev, V., 1924. Sur les equivalentes du Sarmatien supérieur en Serbie. Recueil de traveaux ofert a M. Jovan Cvijic par ses amis et collaborateurs, 73-85.

Lattuada, M., Albrecht, C., Wesselingh, F.P., Klinkenbuß, D., Vinarski, M.V., Kijashko, P., Raes, N., Wilke, T., 2020. Endemic Caspian Sea mollusks in hotspot and non-hotspot areas differentially affected by anthropogenic pressures. Journal of Great Lakes Research. 10.1016/j.jglr.2019.12.007.

Lazarev, S., De Leeuw, A., Stoica, M., Mandic, O., van Baak, C.G.C., Vasiliev, I., Krijgsman, W., 2020. From Khersonian drying to Pontian "flooding“: late Miocene stratigraphy and palaeoenvironmental evolution of the Dacian Basin (Eastern Paratethys). Global and Planetary Change 192, 103224. https://doi.org/10.1016/j. gloplacha.2020.103224

Lazarev, S., Jorissen, E.L., van de Velde, S., Rausch, L., Stoica, M., Wesselingh, F.P., van Baak, C.G.C., Yanina, T.A., Aliyeva, E., Krijgsman, W., 2019. Magneto-biostratigraphic age constraints on the palaeoenvironmental evolution of the South Caspian basin during the Early-Middle Pleistocene (Kura basin, Azerbaijan).

Quaternary Science Reviews 222, 105895. 10.1016/j.quascirev.2019.105895.

Le Pichon, X., Angelier, J., Sibuet, J.-c., 1982. Plate boundaries and extensional tectonics. Tectonophysics 81, 239-256. 10.1016/0040-1951(82)90131-7.

Lebedeva, N.A., 1972. About geological position of terestrial mammal faunas of Khaprovian, Tamanian and Tirasploian faunal complexes in Akchagylian and Apsheronian marine layers of the East Transcaucasia. Bulletin of Comission for study of the Quaternary, 99-115. 
Lee, J.-Y., Marti, K., Severinghaus, J.P., Kawamura, K., Yoo, H.-S., Lee, J.B., Kim, J.S., 2006. A redetermination of the isotopic abundances of atmospheric Ar. Geochimica et Cosmochimica Acta 70, 4507-4512. 10.1016/j. gca.2006.06.1563.

Leever, K.A., 2007. Foreland of the Romanian Carpathians: Controls on late orogenic sedimentary basin evolution and Paratethys paleogeography. [s.n.], [S.1.], XIV, 182.

Leever, K.A., Matenco, L., Rabagia, T., Cloetingh, S., Krijgsman, W., Stoica, M., 2010. Messinian sea level fall in the Dacic Basin (Eastern Paratethys): palaeogeographical implications from seismic sequence stratigraphy. Terra Nova 22, 12-17. 10.1111/j.1365-3121.2009.00910.x.

Livental, V.E., 1929. Ostracoda of Akchagilian and Apsheronian beds of the Babazan section (in Russian). Izvestiya Azerbajdzahnskogo Politekhnischeskogo Instituta, 1-58.

Lüttig, G.W., Steffens, P., 1975. Paleogeographic atlas of Turkey 1:1500000 : from the Oligocene to the Pleistocene. Scherrerdruck.

MacEachern, J., Bann, K., Bhattacharya, J., Howell Jr., C., 2005. Ichnology of Deltas: Organism responses to the Dynamic Interplay of Rivers, Waves, Storms and Tides. River Deltas-Concepts, Models, and Examples: SPEM Special Publication 83.

MacEachern, J.A., Bann, K.L., 2008. The Role of Ichnology in Refining Shallow Marine Facies Models. In: Hampson, G.J., Steel, R.J., Burgess, P.M., Dalrymple, R.W. (Eds.) Recent Advances in Models of Siliciclastic Shallow-Marine Stratigraphy. SEPM (Society for Sedimentary Geology), pp. 73-116.

Mack, G.H., Stout, D.M., 2005. Unconventional distribution of facies in a continental rift basin: the Pliocene-

Pleistocene Mangas Basin, south-western New Mexico, USA. Sedimentology 0, 051010085033001-??? 10.1111/j.1365-3091.2005.00735.x.

Magyar, I., Geary, D.H., Müller, P., 1999. Paleogeographic evolution of the Late Miocene Lake Pannon in Central Europe. Palaeogeography, Palaeoclimatology, Palaeoecology 147, 151-167. 10.1016/S0031-0182(98)00155-2.

Magyar, I., Radivojević, D., Sztanó, O., Synak, R., Ujszászi, K., Pócsik, M., 2013. Progradation of the paleo-

Danube shelf margin across the Pannonian Basin during the Late Miocene and Early Pliocene. Global and Planetary Change 103, 168-173. 10.1016/j.gloplacha.2012.06.007.

Mandic, O., Sant, K., Kallanxhi, M.-E., Ćorić, S., Theobalt, D., Grunert, P., Leeuw, A. de, Krijgsman, W., 2019. Integrated bio-magnetostratigraphy of the Badenian reference section Ugljevik in southern Pannonian Basin - implications for the Paratethys history (middle Miocene, Central Europe). Global and Planetary Change 172, 374-395. 10.1016/j.gloplacha.2018.10.010.

Mangino, S., Priestley, K., 1998. The crustal structure of the southern Caspian region. Geophys. J. Int. 133, 630648. 10.1046/j.1365-246X.1998.00520.x.

Markova, L.P., 1962. Stratigraphy of Pliocene deposits of the oil areas of the West Turkmenia. Printing house of the Academy of Sciences of the Turkmen SSR, Ashgabat.

Marzocchi, A., Flecker, R., van Baak, C.G.C., Lunt, D.J., Krijgsman, W., 2016. Mediterranean outflow pump: An alternative mechanism for the Lago-mare and the end of the Messinian Salinity Crisis. Geology 44, 523-526. 10.1130/G37646.1. 
Matenco, L., Bertotti, G., Cloetingh, S., Dinu, C., 2003. Subsidence analysis and tectonic evolution of the external Carpathian-Moesian Platform region during Neogene times. Sedimentary Geology 156, 71-94. 10.1016/ S0037-0738(02)00283-X.

Matoshko, A., Matoshko, A., Leeuw, A. de, 2019. The Plio-Pleistocene Demise of the East Carpathian Foreland Fluvial System and Arrival of the Paleo-Danube To The Black Sea. Geologica Carpathica 70, 91-112. 10.2478/ geoca-2019-0006.

Matoshko, A., Matoshko, A., Leeuw, A. de, Stoica, M., 2016. Facies analysis of the Balta Formation: Evidence for a large late Miocene fluvio-deltaic system in the East Carpathian Foreland. Sedimentary Geology 343, 165-189. 10.1016/j.sedgeo.2016.08.004.

Matzke-Karasz, R., Witt, W., 2005. Ostracods of the Paratethyan Neogene Kılıç and Yalakdere Formations near Yalova (İzmit Province, Turkey). Zitteliana A45, 111-129.

McCubbin, D.G., 1982. Barrier-Island and Strand Plain Facies. In: Horn, M.K. (Ed.) Sandstone depositional environments, pp. 247-281.

McFadden, P.L., McElhinny, M.W., 1990. Classification of the reversal test in palaeomagnetism. Geophys. J. Int. 103, 725-729. 10.1111/j.1365-246X.1990.tb05683.x.

Meijer, P.T., 2012. Hydraulic theory of sea straits applied to the onset of the Messinian Salinity Crisis. Marine Geology 326-328, 131-139. 10.1016/j.margeo.2012.09.001.

Meijers, M.J.M., Peynircioğlu, A.A., Cosca, M.A., Brocard, G.Y., Whitney, D.L., Langereis, C.G., Mulch, A., 2018. Climate stability in central Anatolia during the Messinian Salinity Crisis. Palaeogeography, Palaeoclimatology, Palaeoecology 498, 53-67. 10.1016/j.palaeo.2018.03.001.

Menard, H.W., 1955. Deep-Sea Channels, Topography, and Sedimentation. Bulletin 39. 10.1306/5CEAE13616BB-11D7-8645000102C1865D.

Miall, A.D., 1996. The geology of fluvial deposits: Sedimentary facies, basin analysis, and petroleum geology / Andrew D. Miall. Springer, Berlin, London.

Micallef, A., Camerlenghi, A., Garcia-Castellanos, D., Cunarro Otero, D., Gutscher, M.-A., Barreca, G., Spatola, D., Facchin, L., Geletti, R., Krastel, S., Gross, F., Urlaub, M., 2018. Evidence of the Zanclean megaflood in the eastern Mediterranean Basin. Scientific reports 8, 1078. 10.1038/s41598-018-19446-3.

Min, K., Mundil, R., Renne, P.R., Ludwig, K.R., 2000. A test for systematic errors in 40Ar/39Ar geochronology through comparison with $\mathrm{U} / \mathrm{Pb}$ analysis of a 1.1-Ga rhyolite. Geochimica et Cosmochimica Acta 64, 73-98.

Moore, R.C., 1961. Glossary of morphological terms applied to Ostracoda. Arthropoda 3, 47-56.

Mordukhai-Boltovskoi, 1964. Caspian Fauna Beyond the Caspian Sea. Int. Revue ges. Hydrobiol. Hydrogr. 49, 139-176. 10.1002/iroh.19640490105.

Morris, E.A., Hodgson, D.M., Flint, S.S., Brunt, R.L., Butterworth, P.J., Verhaeghe, J., 2014. Sedimentology, Stratigraphic Architecture, and Depositional Context of Submarine Frontal-Lobe Complexes. Journal of Sedimentary Research 84, 763-780. 10.2110/jsr.2014.61.

Morton, A., Allen, M., Simmons, M., Spathopoulos, F., Still, J., Hinds, D., Ismail-Zadeh, A., Kroonenberg, S., 2003. Provenance patterns in a neotectonic basin: Pliocene and Quaternary sediment supply to the South Caspian. Basin Res 15, 321-337. 10.1046/j.1365-2117.2003.00208.x. 
Motas, I., Bandrabur, T., Ghenea, C., Sandulescu, M., 1966. Geologic map of Romania: Ploiesti sheet.

Mudie, P.J., Marret, F., Mertens, K.N., Shumilovskikh, L., Leroy, S.A.G., 2017. Atlas of modern dinoflagellate cyst distributions in the Black Sea Corridor: from Aegean to Aral Seas, including Marmara, Black, Azov and Caspian Seas. Marine Micropaleontology 134, 1-152. 10.1016/j.marmicro.2017.05.004.

Mulder, T., Syvitski, J.P.M., Migeon, S., Faugères, J.-C., Savoye, B., 2003. Marine hyperpycnal flows: initiation, behavior and related deposits. A review. Marine and Petroleum Geology 20, 861-882. 10.1016/j. marpetgeo.2003.01.003.

Mullender, T.A.T., Frederichs, T., Hilgenfeldt, C., Groot, L.V. de, Fabian, K., Dekkers, M.J., 2016. Automated paleomagnetic and rock magnetic data acquisition with an in-line horizontal "2G” system. Geochem. Geophys. Geosyst. 17, 3546-3559. 10.1002/2016GC006436.

Mullender, T.A.T., Velzen, A.J., Dekkers, M.J., 1993. Continuous drift correction and separate identification of ferrimagnetic and paramagnetic contributions in thermomagnetic runs. Geophys. J. Int. 114, 663-672. 10.1111/j.1365-246X.1993.tb06995.x.

Muratov, M.V., Nevesskaya, L.A. (Eds.), 1986. Stratigraphy of the USSR: The Neogene sytem. Nedra, Moscow. Myers, P.G., Wielki, C., Goldstein, S.B., Rohling, E.J., 2003. Hydraulic calculations of postglacial connections between the Mediterranean and the Black Sea. Marine Geology 201, 253-267. 10.1016/S00253227(03)00225-1.

Nadirov, R.S., Bagirov, E., Tagiyev, M., Lerche, I., 1997. Flexural plate subsidence, sedimentation rates, and structural development of the super-deep South Caspian Basin. Marine and Petroleum Geology 14, 383-400. 10.1016/S0264-8172(96)00054-2.

Nadon, G.C., Issler, D.R., 1997. The compaction of floodplain sediments: Timing, magnitude and implications. Geoscience Canada 21, 38-42.

Naidina, O.D., Richards, K., 2016. Pollen evidence for Late Pliocene - Early Pleistocene vegetation and climate change in the North Caucasus, North-Western Caspian Region. Quaternary International 409, 50-60. 10.1016/j.quaint.2015.12.018.

Namiotko, T., Danielopol, D.L., Belmecheri, S., Gross, M., Grafenstein, U. von, 2012. On the Leptocytheridae Ostracods of the Long-Lived Lake Ohrid: A Reappraisal of their Taxonomic Assignment and Biogeographic Origin. International review of hydrobiology 97, 356-374. 10.1002/iroh.201211496.

Neubauer, T.A., Harzhauser, M., Kroh, A., Georgopoulou, E., Mandic, O., 2015. A gastropod-based biogeographic scheme for the European Neogene freshwater systems. Earth-Science Reviews 143, 98-116. 10.1016/j. earscirev.2015.01.010.

Nevesskaja, L.A., 2007. History of the genus Didacna (Bivalvia: Cardiidae). Paleontol. J. 41, 861-949. 10.1134/ S0031030107090018.

Nevesskaja, L.A., Goncharova, I.A., Paramonova, N.P., Popov, S.B., Babak, E.B., Bagdasarjan, K.G., Voronina, A.A., 1993. Opredelitelj miocenovjih dvustvorchatjih molljuskov Jugo-Zapadnoi Evrazii. Nauka, Moscow, 412 pp.

Nevesskaja, L.A., Paramonova, N.P., Babak, E.V., 1997. Opredelitel pliocenovih dvustvorchatih molluskov Jugozapadnoj Evrazii. Trudi Paleontologičeskogo instituta. Trudi Paleontologičeskogo instituta 269, 1-220. 
Nevesskaya, L.A., 1958. Quaternary marine molluks of Turkmenia. Proceedings of the Geological Institute, Academy of Sciences of the USSR 65.

Nevesskaya, L.A., Goncharova, I.A., Ilyina, L.B., Paramonova, N.P., Khondkarian, S.O., 2003. The Neogene Stratigraphic Scale of the Eastern Paratethys. Stratigraphy and Geological Correlation 11, 105-127.

Nevesskaya, L.A., Kovalenko, E.I., Beluzhenko, E.V., Popov, S.V., Goncharova, I.A., Danukalova, G.A., Zhidovinov, I.Y., Zaytsev, A.V., Zastrozhnov, A.S., Ilyina, L.B., Paramonova, N.P., Pinchuk, T.N., Pismennaya, N.S., Agadjanian, A.K., Lopatin, A.V., Trubikhin, V.M. (Eds.), 2004. Explanatory letter to the Regional unified stratigraphic scheme of Neogene deposits of the southern regions of the European part of Russia., Moscow.

Nevesskaya, L.A., Popov, S.V., Goncharova, I.A., Guzhov, A.V., Yanin, B.T., Polubotko, I.V., Biakov, A.S., Gavrilova, V.A., 2013. Phanerozoic Bivalvia of Russia and adjacent countries. Tr. Paleontol. Inst. Ross. Akad. Nauk 294, 1-524.

Nevesskaya, L.A., Trubikhin, V.M., 1984. History of the Caspian Basin and its mollusc fauna in the Late Pliocene Early Pleistocene. In: Kamaletdinov, M.A., Yakhimovich, V.L. (Eds.) Antropogen of Eurasia. Nauka, Moscow, pp. 19-27.

Nichols, G., 2009. Sedimentology and stratigraphy, 2nd ed. Wiley-Blackwell, Chichester.

Oliveira, C.M.M., Hodgson, D.M., Flint, S.S., 2009. Aseismic controls on in situ soft-sediment deformation processes and products in submarine slope deposits of the Karoo Basin, South Africa. Sedimentology 56, 1201-1225. 10.1111/j.1365-3091.2008.01029.x.

Oliveira, C.M.M., Hodgson, D.M., Flint, S.S., 2011. Distribution of soft-sediment deformation structures in clinoform successions of the Permian Ecca Group, Karoo Basin, South Africa. Sedimentary Geology 235, 314-330. 10.1016/j.sedgeo.2010.09.011.

Olteanu, R., 1989. La faune dostracodes pontiens du Bassin Dacique. Chronostratigraphie und Neostratotypen, Pliozän Pl1, Pontien, 722-752.

Opluštil, S., Lojka, R., Rosenau, N.A., Strnad, L., Sýkorová, I., 2015. Middle Moscovian climate of eastern equatorial Pangea recorded in paleosols and fluvial architecture. Palaeogeography, Palaeoclimatology, Palaeoecology 440, 328-352. 10.1016/j.palaeo.2015.09.009.

Oppenheim, P., 1919. Das Neogen in Kleinasien. Zeitschrift der Deutschen Geologischen Gesellschaft, 1-210.

Palcu, D.V., Golovina, L.A., Vernyhorova, Y.V., Popov, S.V., Krijgsman, W., 2017. Middle Miocene paleoenvironmental crises in Central Eurasia caused by changes in marine gateway configuration. Global and Planetary Change 158, 57-71. 10.1016/j.gloplacha.2017.09.013.

Palcu, D.V., Popov, S.V., Golovina, L.A., Kuiper, K.F., Liu, S., Krijgsman, W., 2019a. The shutdown of an anoxic giant: Magnetostratigraphic dating of the end of the Maikop Sea. Gondwana Research 67, 82-100. 10.1016/j. gr.2018.09.011.

Palcu, D.V., Tulbure, M., Bartol, M., Kouwenhoven, T.J., Krijgsman, W., 2015. The Badenian-Sarmatian Extinction Event in the Carpathian foredeep basin of Romania: Paleogeographic changes in the Paratethys domain. Global and Planetary Change 133, 346-358. 10.1016/j.gloplacha.2015.08.014. 
Palcu, D.V., Vasiliev, I., Stoica, M., Krijgsman, W., 2019b. The end of the Great Khersonian Drying of Eurasia: Magnetostratigraphic dating of the Maeotian transgression in the Eastern Paratethys. Basin Res 31, 33-58. 10.1111/bre.12307.

Paramonova, N.P., 1994. History of Sarmatian and Akchagylian bivalves. Nauka, Moscow.

Pavelsky, T.M., 2018. World's landlocked basins drying. Nature Geosci 11, 892-893. 10.1038/s41561-018-0269-3.

Peakall, J., McCaffrey, B., Kneller, B., 2000. A Process Model for the Evolution, Morphology, and Architecture of Sinuous Submarine Channels. Journal of Sedimentary Research 70, 434-448. 10.1306/2DC4091C-0E4711D7-8643000102C1865D.

Pettingill, H.S., Weimer, P., 2002. Worlwide deepwater exploration and production: Past, present, and future. The Leading Edge 21, 371-376. 10.1190/1.1471600.

Pevzner, M.A., 1986. Stratigraphy of the Middle Miocene - Pliocene of the South Europe (based on paleomagnetic data). Dissertation, Moscow.

Phillips, D., Matchan, E.L., 2013. Ultra-high precision 40Ar/39Ar ages for Fish Canyon Tuff and Alder Creek Rhyolite sanidine: New dating standards required? Geochimica et Cosmochimica Acta 121, 229-239. 10.1016/j.gca.2013.07.003.

Piller, W.E., Harzhauser, M., Mandic, O., 2007. Miocene Central Paratethys stratigraphy - current status and future directions. Stratigraphy 4, 151-168.

Pimpirev, C., Sarmiento, G., 1993. Submarine fan and channel levee deposits in the Lower Cretaceous Bogota trough, Colombian Andes. Sedimentary Geology 86, 229-246. 10.1016/0037-0738(93)90024-Y.

Pinchuk, T.N., 2006. Biostratigraphy of the Cenozoic beds of Russia and adjacent regions based on foraminifers: Western Caucasus and Ciscaucasia (Oligocene and Neogene). In: Practial Handbook on the microfauna of the USSR: Foraminifers of the Cenozoic. Nedra, Saint Petersburg, pp. 91-98.

Piper, J.D.A., Grant, S., 1989. A palaeomagnetic test of the axial dipole assumption and implications for continental distribution through geological time. Physics of the Earth and Planetary Interiors 55, 37-53. 10.1016/0031-9201(89)90232-X.

Pipík, R., Bodergat, A.-M., 2007. Candoninae trapézoïdales (Crustacea, Ostracoda) du Bassin de Turiec (Slovaquie) du Miocène supérieur : systématique, écologie et évolution. Geobios 40, 645-676. 10.1016/j. geobios.2006.02.003.

Popescu, G., 1995. Contribution of the Sarmatian foraminifera of Romania. Rom. J. Paleontology 76, 85-98. Popescu, S.-M., 2006. Late Miocene and early Pliocene environments in the southwestern Black Sea region from high-resolution palynology of DSDP Site 380A (Leg 42B). Palaeogeography, Palaeoclimatology, Palaeoecology 238, 64-77. 10.1016/j.palaeo.2006.03.018.

Popescu, S.-M., Dalesme, F., Jouannic, G., Escarguel, G., Head, M.J., Melinte-Dobrinescu, M.C., Sütö-Szentai, M., Bakrac, K., Clauzon, G., Suc, J.-P., 2009. Galeacysta etrusca complex: Dinoflagellate cyst marker of paratethyan influxes to the Mediterranean sea before and after the peak of the messinian salinity crisis. Palynology 33, 105-134. 10.1080/01916122.2009.9989688.

Popov, A.V., Nevesskaya, L.A., 2000. Late Miocene brackish-water mollusks and the history of the Aegean Basin. Stratigraphy and Geological Correlation 8, 195-205. 
Popov, G.I., 1970. Apsheronian deposits of the Azov Sea Basin. The Soviet Geology.

Popov, S.V., 2004. Lithological-paleogeographic maps of Paratethys: 10 maps late eocene to pliocene / Popov, S.V.

... [et al.]. E Schweizerbart'sche Verlagsbuchhandlung, Stuttgart.

Popov, S.V., Antipov, M.P., Zastrozhnov, A.S., Kurina, E.E., Pinchuk, T.N., 2010. Sea-level fluctuations on the northern shelf of the Eastern Paratethys in the Oligocene-Neogene. Stratigr. Geol. Correl. 18, 200-224. $10.1134 /$ S0869593810020073.

Popov, S.V., Rostovtseva, Y.V., Fillippova, N.Y., Golovina, L.A., Radionova, E.P., Goncharova, I.A., Vernyhorova, Y.V., Dykan, N.I., Pinchuk, T.N., Iljina, L.B., Koromyslova, A.V., Kozyrenko, T.M., Nikolaeva, I.A., Viskova, L.A., 2016. Paleontology and stratigraphy of the Middle-Upper Miocene of the Taman Peninsula: Part 1. Description of key sections and benthic fossil groups. Paleontol. J. 50, 1039-1206. 10.1134/ S0031030116100014.

Popov, S.V., Shcherba, I.G., Ilyina, L.B., Nevesskaya, L.A., Paramonova, N.P., Khondkarian, S.O., Magyar, I., 2006. Late Miocene to Pliocene palaeogeography of the Paratethys and its relation to the Mediterranean. Palaeogeography, Palaeoclimatology, Palaeoecology 238, 91-106. 10.1016/j.palaeo.2006.03.020.

Posamentier, H.W., Erskine, R.D., Mitchum, R.M., 1991. Models for Submarine-Fan Deposition within a Sequence-Stratigraphic Framework. In: Bouma, A.H., Weimer, P., Link, M.H. (Eds.) Seismic Facies and Sedimentary Processes of Submarine Fans and Turbidite Systems, vol. 59. Springer New York, New York, NY, pp. 127-136.

Posamentier, H.W., Walker, R.G., 2006. Facies Models Revisited. SEPM (Society for Sedimentary Geology).

Raaf, J.F.M., Boersma, J.R., Gelder, A., 1977. Wave-generated structures and sequences from a shallow marine succession, Lower Carboniferous, County Cork, Ireland. Sedimentology 24, 451-483. 10.1111/j.13653091.1977.tb00134.x.

Radionova, E., Golovina, L., Filippova, N., Trubikhin, V., Popov, S., Goncharova, I., Vernigorova, Y., Pinchuk, T., 2012. Middle-Upper Miocene stratigraphy of the Taman Peninsula, Eastern Paratethys. Open Geosciences 4, 925. 10.2478/s13533-011-0065-8.

Rausch, L., Stoica, M., Lazarev, S., 2020. A late Miocene - early Pliocene Paratethyan type ostracod fauna from the Denizli Basin (SW Anatolia) and its paleogeographic implications. Acta Palaeontologica Romaniae, 16(2), 3-56. https://doi.org/10.35463/j.apr.2020.02.01

Reading, H.G., 1996. Sedimentary environments: Processes, facies, and stratigraphy / edited by H.G. Reading, 3rd ed. Blackwell Science, Cambridge, Mass., Oxford.

Reichenbacher, B., Alimohammadian, H., Sabouri, J., Haghfarshi, E., Faridi, M., Abbasi, S., Matzke-Karasz, R., Fellin, M.G., Carnevale, G., Schiller, W., Vasilyan, D., Scharrer, S., 2011. Late Miocene stratigraphy, palaeoecology and palaeogeography of the Tabriz Basin (NW Iran, Eastern Paratethys). Palaeogeography, Palaeoclimatology, Palaeoecology 311, 1-18. 10.1016/j.palaeo.2011.07.009.

Reynolds, A.D., Simmons, M.D., Bowman, M.B.J., Henton, J., Brayshaw, A.C., Ali-Zade, A.A., Guliyev, I.S., Suleymanova, S.F., Ateava, E.Z., Mamedova, D.N., Koshkarly, R.O., 1998. Implications of Outcrop Geology for Reservoirs in the Neogene Productive Series: Apsheron Peninsula, Azerbaijan. AAPG Bulletin 82, 25-49. 
Richards, K., 2018a. Studies in Caspian palynology: Six million years of vegetation, climate and sea level change. PhD Thesis University of Amsterdam. University of Amsterdam, Amsterdam, 264 pp.

Richards, K., van Baak, C.G.C., Athersuch, J., Hoyle, T.M., Stoica, M., Austin, W.E.N., Cage, A.G., Wonders, A.A.H., Marret, F., Pinnington, C.A., 2018b. Palynology and micropalaeontology of the Pliocene - Pleistocene transition in outcrop from the western Caspian Sea, Azerbaijan: Potential links with the Mediterranean, Black Sea and the Arctic Ocean? Palaeogeography, Palaeoclimatology, Palaeoecology 511, 119-143. 10.1016/j. palaeo.2018.07.018.

Rodrı冈guez-Pascua, M.A., Calvo, J.P., Vicente, G. de, Gómez-Gras, D., 2000. Soft-sediment deformation structures interpreted as seismites in lacustrine sediments of the Prebetic Zone, SE Spain, and their potential use as indicators of earthquake magnitudes during the Late Miocene. Sedimentary Geology 135, 117-135. 10.1016/S0037-0738(00)00067-1.

Rögl, F., 1999. Mediterranean and Paratethys. Facts and hypotheses of an Oligocene to Miocene paleogeography (Short overview). Geologica Carpathica 50, 339-349.

Roshka, V.K., 1973. The Meotian mollusks of the south-western Black Sea region. Shtiintsa, Kishinev.

Rostovtseva, Y.V., Rybkina, A.I., 2017. The Messinian event in the Paratethys: Astronomical tuning of the Black Sea Pontian. Marine and Petroleum Geology 80, 321-332. 10.1016/j.marpetgeo.2016.12.005.

Roveri, M., Flecker, R., Krijgsman, W., Lofi, J., Lugli, S., Manzi, V., Sierro, F.J., Bertini, A., Camerlenghi, A., Lange, G. de, Govers, R., Hilgen, F.J., Hübscher, C., Meijer, P.T., Stoica, M., 2014a. The Messinian Salinity Crisis: Past and future of a great challenge for marine sciences. Marine Geology 352, 25-58. 10.1016/j. margeo.2014.02.002.

Roveri, M., Lugli, S., Manzi, V., Gennari, R., Schreiber, B.C., 2014b. High-resolution strontium isotope stratigraphy of the Messinian deep Mediterranean basins: Implications for marginal to central basins correlation. Marine Geology 349, 113-125. 10.1016/j.margeo.2014.01.002.

Rozyeva, T.R., 1971. Composition and stratigraphic distribution of the Tertiary ostracods of Turkmenia. In: Vyalov, O.S. (Ed.) Fossil Ostracoda, Jerusalem, pp. 169-178.

Rybkina, A.I., Kern, A.K., Rostovtseva, Y.V., 2015. New evidence of the age of the lower Maeotian substage of the Eastern Paratethys based on astronomical cycles. Sedimentary Geology 330, 122-131. 10.1016/j. sedgeo.2015.10.003.

Saintot, A., Brunet, M.-F., Yakovlev, F., Sébrier, M., Stephenson, R., Ershov, A., Chalot-Prat, F., McCann, T., 2006. The Mesozoic-Cenozoic tectonic evolution of the Greater Caucasus. Geological Society, London, Memoirs 32, 277-289. 10.1144/GSL.MEM.2006.032.01.16.

Saltykov, V.F., 2011. Pleistocene stratigraphy for the North Caspan Area. Bulletin of Comission for study of the Quaternary, 95-111.

Sant, K., Kirscher, U., Reichenbacher, B., Pippèrr, M., Jung, D., Doppler, G., Krijgsman, W., 2017. Late Burdigalian sea retreat from the North Alpine Foreland Basin: new magnetostratigraphic age constraints. Global and Planetary Change 152, 38-50. 10.1016/j.gloplacha.2017.02.002.

Saraç, G., 2003. Türkiye omurgalı fosil yatakları. Jeoloji Etütleri Dairesi Başkanliği, Ankara. 
Sato, T., Chan, M.A., Ekdale, A.A., 2018. Trace fossils and fluvial-lacustrine Ichnofacies of the Eocene Uinta and Duchesne River Formations, northern Uinta Basin, Utah. giw 5, 209-226. 10.31711/giw.v5i0.27.

Scherer, C.M.S., Goldberg, K., Bardola, T., 2015. Facies architecture and sequence stratigraphy of an early post-rift fluvial succession, Aptian Barbalha Formation, Araripe Basin, northeastern Brazil. Sedimentary Geology 322, 43-62. 10.1016/j.sedgeo.2015.03.010.

Schmid, S.M., Bernoulli, D., Fügenschuh, B., Matenco, L., Schefer, S., Schuster, R., Tischler, M., Ustaszewski, K., 2008. The Alpine-Carpathian-Dinaridic orogenic system: correlation and evolution of tectonic units. Swiss J. Geosci. 101, 139-183. 10.1007/s00015-008-1247-3.

Schulz, H., Bechtel, A., Sachsenhofer, R., 2005. The birth of the Paratethys during the Early Oligocene: From Tethys to an ancient Black Sea analogue? Global and Planetary Change 49, 163-176. 10.1016/j. gloplacha.2005.07.001.

Sedaikin, V.M., 1988. Reference sections of the Quaternary sediments of the North-Western Pre-Caspian. VINITI, 190.

Seilacher, A., 2007. Trace fossil analysis. Springer, Berlin, London.

Semenenko, V.N., Pevzner, M.A., 1979. Correlation of Miocene and Pliocene of the Pont-Caspian on the biostratigraphic and paleomagnetic data. Proceedings of the USSR Academy of Sciences, Geological Series 1, 5-15.

Senes, J., 1961. Paläogeographie des Westkarpatischen Raumes in Beziehung zur übrigen Paratethys im Miozän. Geol. Práce, 1-56.

Şengör, A.M.C., Yilmaz, Y., 1981. Tethyan evolution of Turkey: A plate tectonic approach. Tectonophysics 75, 181-241. 10.1016/0040-1951(81)90275-4.

Seyitoğlu, G., Işık, V., 2015. Late Cenozoic extensional tectonics in Wetern Anatolia: Exhumtion of the Menderes core complex and formation of related basins. Bulletin Of The Mineral Research and Exploration 0. 10.19111/ bmre.49951.

Shanmugam, G., Moiola, R.J., Damuth, J.E., 1985. Eustatic Control of Submarine Fan Development. In: Bouma, A.H., Normark, W.R., Barnes, N.E. (Eds.) Submarine Fans and Related Turbidite Systems, vol. 10. Springer New York, New York, NY, pp. 23-28.

Shantser, E.V. (Ed.), 1982. Stratigraphy of the USSR: Quaternary system. Nedra, Moscow.

Sickenberg, O., Tobien, H., 1971. New Neogene and Lower Quaternary vertebrate faunas in Turkey. Newsl. Stratigr. 1, 51-61.

Sidnev, A.V., 1985. The History of the Pliocene hydrographic system in pre-Urals. Nauka, Moscow.

Simon, D., Palcu, D., Meijer, P., Krijgsman, W., 2019. The sensitivity of middle Miocene paleoenvironments to changing marine gateways in Central Europe. Geol 47, 35-38. 10.1130/G45698.1.

Şimşek, Ş., 1984. Denizli-Kızıldere-Tekkehamam-Tosunlar-Buldan-Yenice alanının jeolojisi ve jeotermal enerji olanakları (Geology and geothermal energy potential of the Denizli-Kızıldere-Tekkehamam-TosunlarBuldan-Yenice area) 7846. General Directorate of Mineral Research and Exploration, Ankara. 
Snel, E., Mărunţeanu, M., Macaleţ, R., Meulenkamp, J.E., van Vugt, N., 2006. Late Miocene to Early Pliocene chronostratigraphic framework for the Dacic Basin, Romania. Palaeogeography, Palaeoclimatology, Palaeoecology 238, 107-124. 10.1016/j.palaeo.2006.03.021.

Sokač, A., 1972. Pannonian and Pontian Ostracode fauna of Mt. Medvednica: Panonska i pontska fauna ostrakoda Medvednice. Palaeontologia Jugoslavica 11, 1-140.

Soliman, A., Riding, J.B., 2017. Late Miocene (Tortonian) gonyaulacacean dinoflagellate cysts from the Vienna Basin, Austria. Review of Palaeobotany and Palynology 244, 325-346. 10.1016/j.revpalbo.2017.02.003.

Soreghan, M.J., Scholz, C.A., Wells, J.T., 1999. Coarse-grained, deep-water sedimentation along a border fault margin of Lake Malawi, Africa; seismic stratigraphic analysis. Journal of Sedimentary Research 69, 832-846. 10.2110/jsr.69.832.

Sosson, M., Stephenson, R., Adamia, S., 2017. Tectonic Evolution of the Eastern Black Sea and Caucasus: an introduction. Geological Society, London, Special Publications 428, 1-9. 10.1144/SP428.16.

Stevanovic, P., Nevesskaya, L.A., Marinescu, F., Sokac, A., Jámbor, A. (Eds.), 1989. Neogen der Westlichen („Zentralen”) Paratethys, Pontien. JAZU \& SANU, Zagreb-Beograd.

Stevanovic, P.M., Iljina, L.B., 1982. Stratigrafija meotisa Vostochnoj Serbii i sosednikh regionov po molluskam. Bull. Acad. serbe sciences et Arts, Cl. Sci. nat. et math. Sci. nat. 82, 105-136.

Stevanovic, P.M., Paramonova, N.P., 1983. Verhni Sarmat (Chersonslii regiojarus) Vostochnogo Paratetisa i ego stratigrafija v predkarpatskoj oblasti Serbii po molluskam. Bull. Acad. serbe sciences et Arts, Cl. Sci. nat. et math. Sci. nat. $83,55-100$.

Stoica, M., Krijgsman, W., Fortuin, A., Gliozzi, E., 2016. Paratethyan ostracods in the Spanish Lago-Mare: More evidence for interbasinal exchange at high Mediterranean sea level. Palaeogeography, Palaeoclimatology, Palaeoecology 441, 854-870. 10.1016/j.palaeo.2015.10.034.

Stoica, M., Lazăr, I., Krijgsman, W., Vasiliev, I., Jipa, D., Floroiu, A., 2013. Paleoenvironmental evolution of the East Carpathian foredeep during the late Miocene-early Pliocene (Dacian Basin; Romania). Global and Planetary Change 103, 135-148. 10.1016/j.gloplacha.2012.04.004.

Stoica, M., Lazăr, I., Vasiliev, I., Krijgsman, W., 2007. Mollusc assemblages of the Pontian and Dacian deposits from the Topolog-Argeș area (southern Carpathian foredeep - Romania). Geobios 40, 391-405. 10.1016/j. geobios.2006.11.004.

Suess, E., 1866. Untersuchungen über den Charakter der österreichischen Tertiärbildungen II. Über die Bedeutung der sogenannten „brackischen Stufe” oder der „Cerithienschichten”. Sitzungsberichte der Akademie der Wissenschaften, mathematisch-naturwissenschaftliche Klasse 54, 218-259.

Sümer, Ö., İnci, U., Sözbilir, H., 2012. Tectono-sedimentary evolution of an Early Pleistocene shallow marine fan-deltaic succession at the western coast of Turkey. Geodinamica Acta 25, 112-131.

10.1080/09853111.2013.877241.

Sümer, Ö., İnci, U., Sözbilir, H., 2013. Tectonic evolution of the Söke Basin: Extension-dominated transtensional basin formation in western part of the Büyük Menderes Graben, Western Anatolia, Turkey. Journal of Geodynamics 65, 148-175. 10.1016/j.jog.2012.06.005.

Sun, S., 1990. Denizli-Uşak Arasinin Jeolojisi ve Linyit Olanaklari (In Turkish). MTA Raporu 9985. 
Sütö-Szentai, M., 1982. A Tengelic-2. sz. fúrás pannóniai képződményeinek szervesvázú mikroplankton és sporomorpha maradványai. Annales Instituti Geologici Publici Hungarici 65.

Sütö-Szentai, M., 2000. Organic walled microplankton zonation of the Pannonian S.L. in the surroundings of the Kaskantyú, Paks and Tengelic (Hungary). Annual Report of the Geological Institute of Hungary. 1994-1995, $153-175$.

Svitoch, A., Yanina, T., 1997. Quaternary deposits of the Caspian Sea coasts. RASKhN, Moscow, 268 pp. Svitoch, A.A., Yanina, T.A., 2007. Data on stratotypes of the neopleistocene-holocene regional and local subdivisions in the Caspian region. Stratigr. Geol. Correl. 15, 536-552. 10.1134/S0869593807050061.

Svitoch, A.A., Yanina, T.A., Novikova, N.G., Sobolev, V.M., Khomenko, A.A., 2010. The Pleistocene of the Manych: (structure and evolution). Geographical faculty MSU, Moscow.

Taktakishvili, I.G., 1977. Towards the Pliocene history of Paratethian mollusk fauna. Metsniereba, Tbilisi.

Tamura, T., 2012. Beach ridges and prograded beach deposits as palaeoenvironment records. Earth-Science Reviews 114, 279-297. 10.1016/j.earscirev.2012.06.004.

Taner, G., 1974. Denizli bölgesi Neojeninin paleontolojik ve stratigrafik etüdü. Bulletin of Mineral Research and Exploration of Turkey (MTA) 82, 89-126.

Tărăpoancă, M., Bertotti, G., Maţenco, L., Dinu, C., Cloetingh, S.A.P.L., 2003. Architecture of the Focşani Depression: A $13 \mathrm{~km}$ deep basin in the Carpathians bend zone (Romania). Tectonics 22, n/a-n/a. $10.1029 / 2002$ TC001486.

Tari, G., Fallah, M., Kosi, W., Floodpage, J., Baur, J., Bati, Z., Sipahioğlu, N.Ö., 2015. Is the impact of the Messinian Salinity Crisis in the Black Sea comparable to that of the Mediterranean? Marine and Petroleum Geology 66, 135-148. 10.1016/j.marpetgeo.2015.03.021.

Tauxe, L., 2010. Essentials of Paleomagnetism. University of California Press, Berkeley.

Tauxe, L., Kent, D.V., 2004. A Simplified Statistical Model for the Geomagnetic Field and the Detection of Shallow Bias in Paleomagnetic Inclinations: was the Ancient Magnetic Field Dipolar? In: Channell, J.E.T., Kent, D.V., Lowrie, W., Meert, J.G. (Eds.) Timescales Of The Paleomagnetic Field. American Geophysical Union, Washington, D. C., pp. 101-115.

Taviani, M., Remia, A., Esu, D., Sami, M., 2007. Messinian Lago-Mare mollusc fauna from the Gorgona Island slope, Tyrrhenian Sea. Geobios 40, 351-358. 10.1016/j.geobios.2007.02.001.

ter Borgh, M., Stoica, M., Donselaar, M.E., Matenco, L., Krijgsman, W., 2014. Miocene connectivity between the Central and Eastern Paratethys: Constraints from the western Dacian Basin. Palaeogeography, Palaeoclimatology, Palaeoecology 412, 45-67. 10.1016/j.palaeo.2014.07.016.

ter Borgh, M., Vasiliev, I., Stoica, M., Knežević, S., Matenco, L., Krijgsman, W., Rundić, L., Cloetingh, S., 2013. The isolation of the Pannonian basin (Central Paratethys): New constraints from magnetostratigraphy and biostratigraphy. Global and Planetary Change 103, 99-118. 10.1016/j.gloplacha.2012.10.001.

Tesakov, A.S., 2004. Biostratigrafija srednego pliocena-ėoplejstocena Vostočnoj Evropy: (po melkim mlekopitajuščim). Nauka, Moskva, 246 pp.

1958. The Venice System for the Classification of Marine Waters According to Salinity. Limnol. Oceanogr. 3, 346-347. 10.4319/lo.1958.3.3.0346. 
Topal, S., Özkul, M., 2014. Soft-sediment deformation structures interpreted as seismites in the Kolankaya Formation, Denizli Basin (SW Turkey). TheScientificWorldJournal 2014, 352654. 10.1155/2014/352654. Trubikhin, V.M., 1977. Paleomagnetism and stratigraphy of Akchagylian deposits of West Turkmenia, Moscow. Trubikhin, V.M., 1989. Paleomagnetic data from the Pontian. In: Stevanovic, P., Nevesskaya, L.A., Marinescu, F., Sokac, A., Jámbor, A. (Eds.) Neogen der Westlichen („Zentralen”) Paratethys, Pontien. JAZU \& SANU, Zagreb-Beograd, pp. 76-79.

Tucker, M.E., 2011. Sedimentary rocks in the field: A practical guide / Maurice E. Tucker, 4th ed. WileyBlackwell, Oxford.

Tucker, M.E., 2012. Sedimentary Rocks in the Field: A Practical Guide. Environmental \& Engineering Geoscience 18, 401-402. 10.2113/gseegeosci.18.4.401-b.

Tugolesov, D.A., Gorshkov, A.S., Meisner, L.B., Solov'ev, V.V., Khakhalev, E.M., 1985. Tectonic of the of the MezoCeinozoic deposits in the Black Sea depression (In Russian). Nedra, Moscow.

Tunoglu, C., Ünal, A., 2001. Pannonian-Pontian Ostracod fauna of Gelibolu Neogene Basin (NW Turkey). Yerbilimleri 23, 167-187.

Tunoğlu, C., 2003. Systematics and biostratigraphy of the Pontian Candonidae (Ostracoda) from the eastern Black Sea region (Northern Turkey). Geologica carparthica-Brastislava 54, 21-40.

Tzanova, A., Herbert, T.D., Peterson, L., 2015. Cooling Mediterranean Sea surface temperatures during the Late Miocene provide a climate context for evolutionary transitions in Africa and Eurasia. Earth and Planetary Science Letters 419, 71-80. 10.1016/j.epsl.2015.03.016.

Üner, S., 2014. Seismogenic structures in Quaternary lacustrine deposits of Lake Van (eastern Turkey). Geologos 20, 79-87. 10.2478/logos-2014-0011.

van Baak, C.G.C., 2015a. Mediterranean-Paratethys connectivity during the late Miocene to Recent: Unravelling geodynamic and paleoclimatic causes of sea-level change in semi-isolated basins. Doctoral dissertation, Utrecht.

van Baak, C.G.C., Grothe, A., Richards, K., Stoica, M., Aliyeva, E., Davies, G., Kuiper, K.F., Krijgsman, W., 2019. Flooding of the Caspian Sea at the intensification of Northern Hemisphere Glaciations. Global and Planetary Change.

van Baak, C.G.C., Krijgsman, W., Magyar, I., Sztanó, O., Golovina, L.A., Grothe, A., Hoyle, T.M., Mandic, O., Patina, I.S., Popov, S.V., Radionova, E.P., Stoica, M., Vasiliev, I., 2017. Paratethys response to the Messinian salinity crisis. Earth-Science Reviews 172, 193-223. 10.1016/j.earscirev.2017.07.015.

van Baak, C.G.C., Mandic, O., Lazar, I., Stoica, M., Krijgsman, W., 2015b. The Slanicul de Buzau section, a unit stratotype for the Romanian stage of the Dacian Basin (Plio-Pleistocene, Eastern Paratethys). Palaeogeography, Palaeoclimatology, Palaeoecology 440, 594-613. 10.1016/j.palaeo.2015.09.022.

van Baak, C.G.C., Stoica, M., Grothe, A., Aliyeva, E., Krijgsman, W., 2016. Mediterranean-Paratethys connectivity during the Messinian salinity crisis: The Pontian of Azerbaijan. Global and Planetary Change 141, 63-81. 10.1016/j.gloplacha.2016.04.005. 
van Baak, C.G.C., Vasiliev, I., Stoica, M., Kuiper, K.F., Forte, A.M., Aliyeva, E., Krijgsman, W., 2013. A magnetostratigraphic time frame for Plio-Pleistocene transgressions in the South Caspian Basin, Azerbaijan. Global and Planetary Change 103, 119-134. 10.1016/j.gloplacha.2012.05.004.

van Cappelle, M., Stukins, S., Hampson, G.J., Johnson, H.D., 2016. Fluvial to tidal transition in proximal, mixed tide-influenced and wave-influenced deltaic deposits: Cretaceous lower Sego Sandstone, Utah, USA. Sedimentology 63, 1333-1361. 10.1111/sed.12267.

van der Kolk, D.A., Flaig, P.P., Hasiotis, S.T., 2015. Paleoenvironmental Reconstruction of A Late Cretaceous, Muddy, River-Dominated Polar Deltaic System: Schrader Bluff-Prince Creek Formation Transition, Shivugak Bluffs, North Slope of Alaska, U.S.A. Journal of Sedimentary Research 85, 903-936. 10.2110/jsr.2015.58. van Dijk, I., Nooijer, L.J. de, Hart, M.B., Reichart, G.-J., 2016. The long-term impact of magnesium in seawater on foraminiferal mineralogy: Mechanism and consequences. Global Biogeochem. Cycles 30, 438-446. $10.1002 / 2015$ GB005241.

van Hinsbergen, D.J.J., 2010a. A key extensional metamorphic complex reviewed and restored: The Menderes Massif of western Turkey. Earth-Science Reviews 102, 60-76. 10.1016/j.earscirev.2010.05.005.

van Hinsbergen, D.J.J., Dekkers, M.J., Bozkurt, E., Koopman, M., 2010b. Exhumation with a twist: Paleomagnetic constraints on the evolution of the Menderes metamorphic core complex, western Turkey. Tectonics 29. 10.1029/2009TC002596.

van Hinsbergen, D.J.J., Maffione, M., Plunder, A., Kaymakc1, N., Ganerød, M., Hendriks, B.W.H., Corfu, F., Gürer, D., Gelder, G.I.N.O. de, Peters, K., McPhee, P.J., Brouwer, F.M., Advokaat, E.L., Vissers, R.L.M., 2016. Tectonic evolution and paleogeography of the Kırşehir Block and the Central Anatolian Ophiolites, Turkey. Tectonics 35, 983-1014. 10.1002/2015TC004018.

van Leeuwen, C.H.A., van der Velde, G., van Groenendael, J.M., Klaassen, M., 2012a. Gut travellers: internal dispersal of aquatic organisms by waterfowl. J Biogeogr 39, 2031-2040. 10.1111/jbi.12004.

van Leeuwen, C.H.A., van der Velde, G., van Lith, B., Klaassen, M., 2012b. Experimental quantification of long distance dispersal potential of aquatic snails in the gut of migratory birds. PloS one 7, e32292. 10.1371/ journal.pone.0032292.

Van Morkhoven, Frank P. C. M., 1962. Post-palaeozoic Ostracoda, their morphology, taxonomy and economic use. Elsevier Pub. Co, Amsterdam, New York.

Vasiliev, I., Franke, C., Meeldijk, J.D., Dekkers, M.J., Langereis, C.G., Krijgsman, W., 2008. Putative greigite magnetofossils from the Pliocene epoch. Nature Geosci 1, 782-786. 10.1038/ngeo335.

Vasiliev, I., Iosifidi, A.G., Khramov, A.N., Krijgsman, W., Kuiper, K., Langereis, C.G., Popov, V.V., Stoica, M., Tomsha, V.A., Yudin, S.V., 2011. Magnetostratigraphy and radio-isotope dating of upper Miocene-lower Pliocene sedimentary successions of the Black Sea Basin (Taman Peninsula, Russia). Palaeogeography, Palaeoclimatology, Palaeoecology 310, 163-175. 10.1016/j.palaeo.2011.06.022.

Vasiliev, I., Karakitsios, V., Bouloubassi, I., Agiadi, K., Kontakiotis, G., Antonarakou, A., Triantaphyllou, M., Gogou, A., Kafousia, N., Rafélis, M., Zarkogiannis, S., Kaczmar, F., Parinos, C., Pasadakis, N., 2019a. Large Sea Surface Temperature, Salinity, and Productivity-Preservation Changes Preceding the Onset of the 
Messinian Salinity Crisis in the Eastern Mediterranean Sea. Paleoceanography and Paleoclimatology 34, 182-202. 10.1029/2018PA003438.

Vasiliev, I., Krijgsman, W., Langereis, C.G., Panaiotu, C.E., Maţenco, L., Bertotti, G., 2004. Towards an astrochronological framework for the eastern Paratethys Mio-Pliocene sedimentary sequences of the Focşani basin (Romania). Earth and Planetary Science Letters 227, 231-247. 10.1016/j.epsl.2004.09.012.

Vasiliev, I., Krijgsman, W., Stoica, M., Langereis, C.G., 2005. Mio-Pliocene magnetostratigraphy in the southern Carpathian foredeep and Mediterranean-Paratethys correlations. Terra Nova 17, 376-384. 10.1111/j.13653121.2005.00624.x.

Vasiliev, I., Leeuw, A. de, Filipescu, S., Krijgsman, W., Kuiper, K., Stoica, M., Briceag, A., 2010. The age of the Sarmatian-Pannonian transition in the Transylvanian Basin (Central Paratethys). Palaeogeography, Palaeoclimatology, Palaeoecology 297, 54-69. 10.1016/j.palaeo.2010.07.015.

Vasiliev, I., Maţenco, L., Krijgsman, W., 2009. The syn- and post-collisional evolution of the Romanian Carpathian foredeep: New constraints from anisotropy of magnetic susceptibility and paleostress analyses. Tectonophysics 473, 457-465. 10.1016/j.tecto.2009.04.002.

Vasiliev, I., Reichart, G.-J., Grothe, A., Sinninghe Damsté, J.S., Krijgsman, W., Sangiorgi, F., Weijers, J.W.H., van Roij, L., 2015. Recurrent phases of drought in the upper Miocene of the Black Sea region. Palaeogeography, Palaeoclimatology, Palaeoecology 423, 18-31. 10.1016/j.palaeo.2015.01.020.

Vasiliev, I., Reichart, G.-J., Krijgsman, W., Mulch, A., 2019b. Black Sea rivers capture significant change in catchment-wide mean annual temperature and soil $\mathrm{pH}$ during the Miocene-to-Pliocene transition. Global and Planetary Change 172, 428-439. 10.1016/j.gloplacha.2018.10.016.

Vasilyan, D., Roček, Z., Ayvazyan, A., Claessens, L., 2019. Fish, amphibian and reptilian faunas from latest Oligocene to middle Miocene localities from Central Turkey. Palaeobio Palaeoenv 99, 723-757. 10.1007/ s12549-019-00405-3.

Vecchi, G.A., Soden, B.J., 2007. Global Warming and the Weakening of the Tropical Circulation. J. Climate 20, 4316-4340. 10.1175/JCLI4258.1.

Veen, J.H. ten, Boulton, S.J., Alçiçek, M.C., 2009. From palaeotectonics to neotectonics in the Neotethys realm: The importance of kinematic decoupling and inherited structural grain in SW Anatolia (Turkey). Tectonophysics 473, 261-281. 10.1016/j.tecto.2008.09.030.

Vekilov, B.G., 1969. Anthropogenic deposits of North-Eastern Azerbaijan. ELM, Baku, 218 pp.

Vekua, A., 1972. Kvabebi fauna of Akchagylian vertebrates: (in Russian). Nauka, Moscow.

Vekua, M.K., 1975. The ostracods of the Kimmerian and Kujalinikian deposits of Abkhazia and their stratigraphic significance. Metsniereba, Tbilisi, 137 pp.

Vellinga, M., Wood, R.A., 2002. Global Climatic Impacts of a Collapse of the Atlantic Thermohaline Circulation. Climatic Change 54, 251-267. 10.1023/A:1016168827653.

Verbrugge, L.N.H., Schipper, A.M., Huijbregts, M.A.J., van der Velde, G., Leuven, R.S.E.W., 2012. Sensitivity of native and non-native mollusc species to changing river water temperature and salinity. Biol Invasions 14, 1187-1199. 10.1007/s10530-011-0148-y. 
Vereshchagin, V.N. (Ed.), 1982. Stratigraphic dictionary of the USSR: Paleogene, Neogene, Quternary system. Nedra, Leningrad.

Vincent, S.J., Davies, C.E., Richards, K., Aliyeva, E., 2010. Contrasting Pliocene fluvial depositional systems within the rapidly subsiding South Caspian Basin; a case study of the palaeo-Volga and palaeo-Kura river systems in the Surakhany Suite, Upper Productive Series, onshore Azerbaijan. Marine and Petroleum Geology 27, 2079-2106. 10.1016/j.marpetgeo.2010.09.007.

Vinogradov, A.P., 1969. Atlas of lithological-paleogeographical maps of the Soviet Union. Moscow, Vses. Aerogeol. Trest Mingeol. SSSR.

Wang, J., Song, C., Reager, J.T., Yao, F., Famiglietti, J.S., Sheng, Y., MacDonald, G.M., Brun, F., Schmied, H.M., Marston, R.A., Wada, Y., 2018. Recent global decline in endorheic basin water storages. Nature Geosci 11, 926-932. 10.1038/s41561-018-0265-7.

Welter-Schultes, F.W., 2012. European non-marine molluscs, a guide for species identification =

Bestimmungsbuch für europäische Land- und Süsswassermollusken, 1st ed. Planet Poster, Göttingen, 760 pp.

Went, D.J., Hamilton, R.V., Platt, N.H., Underhill, J.R., 2013. Role of forced regression in controlling Brent Group reservoir architecture and prospectivity in the northern North Sea. Petroleum Geoscience 19, 307-328.

10.1144/petgeo2013-028.

Wenz, W., 1942. Die Mollusken des Pliozäns der rumänischen Erdöl-Gebiete als Leitversteinerungen für die Aufschluss-Abeiten. Senckenbergiana 24, 1-293.

Wesselingh, F.P., Alçiçek, H., Magyar, I., 2008. A Late Miocene Paratethyan mollusc fauna from the Denizli Basin (southwestern Anatolia, Turkey) and its regional palaeobiogeographic implications. Geobios 41, 861-879. 10.1016/j.geobios.2008.07.003.

Wesselingh, F.P., Cadée, G.C., Renema, W., 1999. Flying high: on the airborne dispersal of aquatic organisms as illustrated by the distribution histories of the gastropod genera Tryonia and Planorbarius. Geologie en Mijnbouw 78, 165-174. 10.1023/A:1003766516646.

Wesselingh, F.P., Neubauer, T.A., Anistratenko, V.V., Maxim, V.V., Yanina, T., Ter Poorten, J.J., Kijashko, P., Albrecht, C., Anistratenko, O.Y., D’Hont, A., Frolov, P., Ándara, A.M., Gittenberger, A., Gogaladze, A., Mikhail, K., Lattuada, M., Popa, L., Sands, A.F., van de Lde, S.V., Vandendorpe, J., Wilke, T., 2019. Mollusc species from the Pontocaspian region - an expert opinion list. ZooKeys 827, 31-124. 10.3897/ zookeys.827.31365.

Westaway, R., 1993. Neogene evolution of the Denizli region of western Turkey. Journal of Structural Geology 15, 37-53. 10.1016/0191-8141(93)90077-N.

Westaway, R., Pringle, M., Yurtmen, S., Demir, T., Bridgland, D., Rowbotham, G., Maddy, D., 2004. Pliocene and Quaternary regional uplift in western Turkey: the Gediz River terrace staircase and the volcanism at Kula. Tectonophysics 391, 121-169. 10.1016/j.tecto.2004.07.013.

Willmann, R., 1981. Evolution, Systematik und stratigraphische Bedeutung der neogenen Süßwassergastropoden von Rhodos und Kos/Ägäis. Palaeontographica.

Willmann, R., 1982. Biostratigraphisch wichtige Süßwassergastropoden (Prosobranchia, Hydrobiidae) aus dem Neogen des Agäis-Raumes. Neues Jahrbuch für Geologie und Paläontologie, Abhandlungen 162, 304-331. 
WoRMS Editorial Board. World Register of Marine Species. Available from http://www.marinespecies.org at VLIZ. Accessed 2019-10-04.

Yakhimovich, V.L., Suleymanova, F.I., 1981. Magnetostratigraphic section of the Pliocene and Lower Pleistocene of the non-glacial zone of the Pre-Urals. Bulletin of the Commission for the Study of the Quaternary Period, $31-37$.

Yakhimovich, V.L., Suleymanova, F.I., Danukalova, G.A., Popova-Lvova, M.G., Yakovlev, A.G., Akhlestina, E.F., Nemkova, V.K., Alimbekova, L.I., 2000. The Pliocene and Pleistocene reference section Domashkinskie Vershiny. Gilem, Ufa.

Yalçınlar, I., 1983. Türkiye’de Neojen ve Kuvaterner omurgalı arazileri ve jeomorfolojik karakterleri [Neogene and Quaternary Vertebrate Fields of Turkey and their Geomorphologic Characteristics]. Publication of Faculty of Literature, Istanbul.

Yanina, T.A., 2012. Neopleistocene of the Pontocaspian region: biostratigraphy, palaeogeography and correlation. Geographical faculty MSU, Moscow.

Yanina, T.A., 2013. Biostratigraphy of the Middle and Upper Pleistocene of the Caspian Region. Quaternary International 284, 85-97. 10.1016/j.quaint.2012.02.008.

Yanko, V.V., 1989. Quaternary foraminifera of the Pontocaspian region. Doctoral thesis, Odessa.

Yassini, I., 1986. Ecology, paleoecology and stratigraphy of ostracodes from Upper Pliocene and Quaternary deposits of the South Caspian Sea, North Iran.

Yoshida, S., 2000. Sequence and facies architecture of the upper Blackhawk Formation and the Lower Castlegate Sandstone (Upper Cretaceous), Book Cliffs, Utah, USA. Sedimentary Geology 136, 239-276. 10.1016/S00370738(00)00104-4.

Zastrozhnov, A.S., Shkatova, V.K., Minina, E.A., Tarnogradskiy, V.D., Astakhov, V.I., Gusev, E.A., 2013. Map of Quaternary deposits of the Russian Federation. Scale 1:250000: Explanatory letter. Ministry of nature of Russia, Rosnedra, VSEGEI, All Russian Research Institute of Geology and Mineral Resources of the Ocean, Saint Petersburg.

Zhu, Y., Bhattacharya, J.P., Li, W., Lapen, T.J., Jicha, B.R., Singer, B.S., 2012. Milankovitch-Scale Sequence Stratigraphy and Stepped Forced Regressions of the Turonian Ferron Notom Deltaic Complex, South-Central Utah, U.S.A. Journal of Sedimentary Research 82, 723-746. 10.2110/jsr.2012.63.

Zonenshain, L.P., Le Pichon, X., 1986. Deep basins of the Black Sea and Caspian Sea as remnants of Mesozoic back-arc basins. Tectonophysics 123, 181-211.

Zonneveld, K.A.F., Marret, F., Versteegh, G.J.M., Bogus, K., Bonnet, S., Bouimetarhan, I., Crouch, E., Vernal, A. de, Elshanawany, R., Edwards, L., Esper, O., Forke, S., Grøsfjeld, K., Henry, M., Holzwarth, U., Kielt, J.-F., Kim, S.-Y., Ladouceur, S., Ledu, D., Chen, L., Limoges, A., Londeix, L., Lu, S.-H., Mahmoud, M.S., Marino, G., Matsouka, K., Matthiessen, J., Mildenhal, D.C., Mudie, P., Neil, H.L., Pospelova, V., Qi, Y., Radi, T., Richerol, T., Rochon, A., Sangiorgi, F., Solignac, S., Turon, J.-L., Verleye, T., Wang, Y., Wang, Z., Young, M., 2013. Atlas of modern dinoflagellate cyst distribution based on 2405 data points. Review of Palaeobotany and Palynology 191, 1-197. 10.1016/j.revpalbo.2012.08.003.

Zubakov, V.A. (Ed.), 1974. Geochronology of the USSR. The Late Pliocene and Quaternary. Nedra, Leningrad. 
Zubakov, V.A., Borzenkova, I.I., 1990. Global palaeoclimate of the late Cenozoic. Elsevier, Amsterdam, 456 pp. Zubakov, V.A., Kochegura, V.V., 1976. Magnetochronological scale of the latest stage (5 Ma). Geomagnetic Research, 37-44. 